UNIVERSIDADE DE SÃO PAULO

ESCOLA DE ENGENHARIA DE SÃO CARLOS

DEPARTAMENTO DE ENGENHARIA HIDRÁULICA E SANEAMENTO

PRODUÇÃO DE HIDROGÊNIO E METANO A PARTIR DE SUBPRODUTO DA INDÚSTRIA SUCROALCOOLEIRA, EM REATORES ANAERÓBIOS DE FASES SEPARADAS SOB CONDIÇÃO TERMOFÍLICA

VERSÃO CORRIGIDA

SÃO CARLOS

2017 

ROGERIO SILVEIRA VILELA

\section{PRODUÇÃO DE HIDROGÊNIO E METANO A PARTIR DE SUBPRODUTO DA INDÚSTRIA SUCROALCOOLEIRA, EM REATORES ANAERÓBIOS DE FASES SEPARADAS SOB CONDIÇÃO TERMOFÍLICA}

Tese apresentada à Escola de Engenharia de São Carlos, da Universidade de São Paulo, como parte dos requisitos para a obtenção do título de Doutor em Ciências: Engenharia Hidráulica e Saneamento.

Orientadora: Profa. Dra. Márcia Helena Rissato Zamariolli Damianovic 
AUTORIZO A REPRODUÇÃO TOTAL OU PARCIAL DESTE TRABALHO, POR QUALQUER MEIO CONVENCIONAL OU ELETRÔNICO, PARA FINS DE ESTUDO E PESQUISA, DESDE QUE CITADA A FONTE.

Vilela, Rogerio Silveira

PRODUÇÃO DE HIDROGÊNIO E METANO A PARTIR DE SUBPRODUTO DA INDÚSTRIA SUCROALCOOLEIRA EM REATORES ANAERÓBIOS DE FASES SEPARADAS SOB CONDIÇÃO TERMOFÍLICA / Rogerio Silveira Vilela; orientadora Dra. Márcia Helena Rissato Zamariolli Damianovic . São Carlos, 2017.

Tese (Doutorado) - Programa de Pós-Graduação em Engenharia Hidráulica e Saneamento e Área de Concentração em Hidráulica e Saneamento -- Escola de Engenharia de São Carlos da Universidade de São Paulo, 2017.

1. Produção de Hidrogênio. 2. Produção de Metano. 3. Processos anaeróbios de separação de fases. 4. Condição termofilica. 5. Indústria sucroalcooleira. 6 . Melaço de Cana-de-açúcar. I. Título. 


\section{FOLHA DE JULGAMENTO}

Candidato: Licenciado ROGERIO SILVEIRA VILEIA.

Título da tese: "Produção de hidrogênio e mețano a partir de subproduto da indústria sucroalcooleira, em reatores anaeróbios de fases separadas sob condição termofílica".

Data da defesa: 02/12/2016.

Comissāo Julgadora:

Resultado:

Profa. Dra. Márcia Helena Rissato Zamariolli Damianovic (Orientadora)

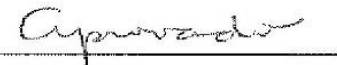

(Escola de Engenharia de São Carlos/EESC)

Prof. Titular Eduardo Cleto Pires

(Escola de Engenharia de São Carlos/EESC)

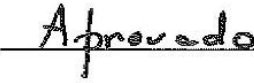

Dra. Valéria Del Nery

(Pós-Doutoranda/CNPq)

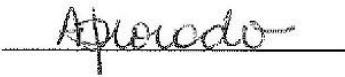

Profa. Dra. Flávia Talarico Saia

(Universidade Federal de São Paulo/UNIFESP)

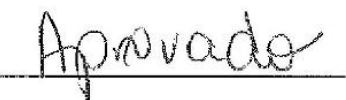

Prof. Dr. Erich Kellner

ApronAdo

(Universidade Federal de São Carlos/UFSCar)

Coordenadora do Programa de Pós-Graduação em Engenharia Hidráulica e Saneamento:

Profa. Associada Maria Bernadefe A. Varesche Silva

Presidente da Comissão de Pós-Graduação:

Prof. Associado Luis Fernando Costa Alberto 

Dedico este trabalho aos meus pais Oraci e Terezinha e especialmente a minha Tia Aparecida. 



\section{AGRADECIMENTOS}

À Deus por nunca me desamparar nessa jornada.

Ao povo do estado de São Paulo e da cidade de São Carlos.

À Universidade de São Paulo (USP), à Escola de Engenharia de São Carlos (EESC), ao Programa de Pós-Graduação do Departamento de Engenharia Hidráulica e Saneamento (PPG-SHS) e ao Laboratório de Processos Biológicos (LPB).

À minha orientadora Profa. Dra. Márcia Damianovic, que dispensa comentários, uma pessoa maravilhosa com quem tive o imenso prazer de trabalhar durante 6 anos da minha estadia na USP, um dos maiores exemplos de profissionalismo e amor pela arte de lecionar, além de uma capacidade incrível de passar adiante o conhecimento, sei que fui um dos "filhos mais velhos" que mais dava trabalho, agradeço a cada ensinamento, puxão de orelha, paciência, dedicação; esta Tese foi fruto de um trabalho árduo, no entanto, o segundo desafio que recebi e ao mesmo tempo o segundo presente (o primeiro foi o trabalho de mestrado).

À grande amiga, Profa. Dra. Flávia Talarico Saia, pela sua coorientação, dedicação do seu tempo, agradeço a todo o suporte que disponibilizou para fazer esta Tese acontecer e se tornou parte integrante deste trabalho, além do alicerce de toda a parte da biologia molecular na qual entrei em contato.

À FAPESP pelo auxílio financeiro para pesquisa (Processo 2012/51496-3) e à CAPES pela bolsa de estudos.

À Usina de Açúcar e Álcool São Martinho em Pradópolis/SP, pelo fornecimento da matéria prima.

À Eloisa Pozzi e a Isabel Sakamoto, que auxiliou nas técnicas de Biologia Molecular.

À Janjinha, Inês e Carol Sabatini pela paciência e ajuda nos laboratórios de cromatografia e de análises físico químicas.

Aos professores do LPB, Eugenio Foresti, Marcelo Zaiat, Maria Bernadete, pelos ensinamentos.

À Valeria Del Nery pela ajuda nos momentos de dúvidas.

Aos funcionários do SHS, Silvana, Fernando, Rose, Sá e Priscila. 
Aos amigos do LPB, que passaram pelo mestrado e os que conviveram junto no doutorado, Bruno Pessoto, Carla Diniz, Carol Gil, Cristiane Arruda, Djalma Ferraz, Drica Maluf, Eduardo Pentenado, Fabrício Motteran, Felipe Vasconcelos, Guilherme Oliveira, Guilherme Peixoto, Guilherme Vuitik, Inaê Alves, Juliana Kawanishi, Laís Américo, Leandro Godoi, Lívia Botta, Lucas Fuess, Lucas Marcon, Mara Rubia, Marcus Vinicius, Moara Barbosa, Paulo Clairmont, Priscila Camiloti, Rachel Biancalana, Rodrigo Carneiro, Samuel Aquino, Simone Dasmaceno, Tainá Franco, Thaís Macedo, Theo Souza, Tiago Martins, Vinicius Masquetti, Vivian Carminato.

Aos grandes amigos e irmãos da República Cooperativa dos Lokos: Danilo (Diogo), Fernando (Txe), Phellipe (Alecrim), Rafael (Vitor), Seu Jorge (Felipe), Vinícius (Bidjei); e aos que estiveram de passagem pela rep, Giovane, João, Leonardo, Mário, Murilo, Wilson e para a grande Zupinha.

Aos amigos da Rio Grande Engenharia, Marcelo, Gerra, Wellington, Louise, Monique, Fernanda, Mônica, Lays, Natália, Elisângela, e ARS engenharia Álvaro e Talyta.

À galera do Crossfit 9 de Julho (CF9J) local onde aprendi a gostar de esporte.

À galera dos MCs e MGs de Passos/MG.

À Associação Espírita Santo Agostinho (AESA).

Às professoras de graduação Nelci, Odila e Mara, pelo incentivo aos primeiros passos rumo a essa jornada.

À Tia Nilma (in memoriam) que sempre acreditou em mim, que sem ela nunca teria chegado tão longe.

A todos que contribuíram de certa forma, direta ou indiretamente, para a realização deste trabalho.

Muito Obrigado... 


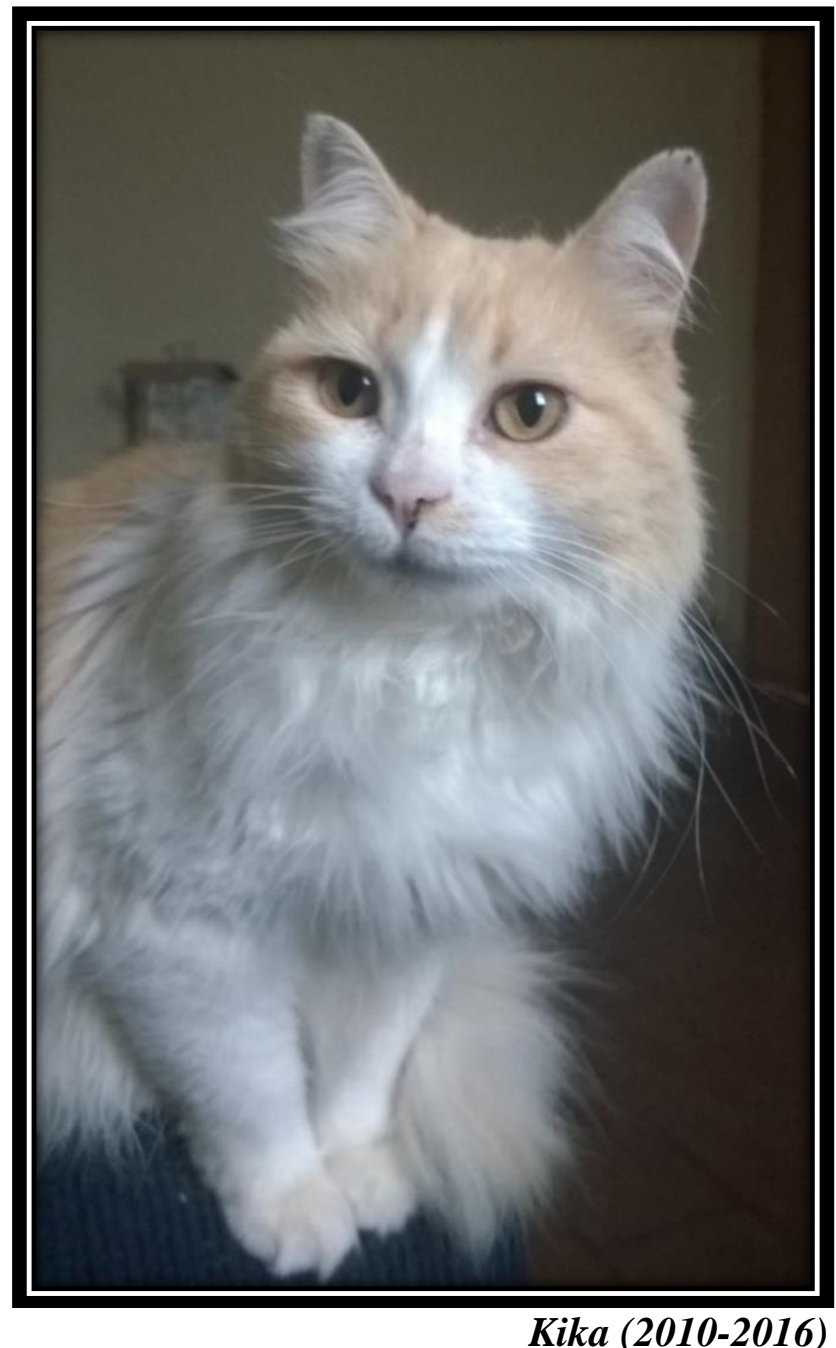

“ Nós seres humanos, estamos na natureza para auxiliar o progresso dos animais, na mesma proporção que os anjos estão para nos auxiliar. Portanto quem chuta ou maltrata um animal é alguém que não aprendeu a amar. "

"O que mais me atrai nos animais é que eles não usam palavras, eles usam sentimentos.

Chico Xavier 



\section{RESUMO}

VILELA, R.S. (2017). Produção de hidrogênio e metano a partir de subproduto da indústria sucroalcooleira, em reatores anaeróbios de fases separadas sob condição termofílica. Tese (Doutorado) - Escola de Engenharia de São Carlos, Universidade de São Paulo. 164p.

A digestão anaeróbia tem se apresentado como um processo de grande interesse sob a ótica da potencial produção de energia renovável $\left(\mathrm{H}_{2}\right.$ e $\left.\mathrm{CH}_{4}\right)$, considerando-se a ampla variedade de compostos orgânicos que podem ser utilizados. Neste estudo desejou-se avançar na compreensão do sistema de reatores anaeróbios de duas fases (acidogênico seguido de metanogênico) operados em condições termofílicas $\left(55^{\circ} \mathrm{C}\right)$, alimentados com melaço da canade-açúcar, subproduto da indústria sucroalcooleira. Os experimentos foram conduzidos em reatores anaeróbios de leito fixo estruturado com fluxo ascendente e o melaço foi diluído com água de abastecimento, para adequação da concentração aos processos de tratamento de águas residuárias. $\mathrm{Na} 1^{\mathrm{a}}$ Etapa dois reatores acidogênicos foram operados em paralelo para avaliar diferentes formas de inoculação e meios suportes, a fim de manter a produção continua e estável de hidrogênio. Para isso foram aplicadas diferentes cargas orgânicas $\left(2,5,5\right.$ e 10 gDQO.L $\left.{ }^{-1}\right)$ que resultam em COV de 30, 60 e 120 g.DQO.Lreator ${ }^{1}$.dia ${ }^{-1}$, com TDH fixo de 2 horas. A expressão do gene hidrogenase foi detectado em ambos os reatores, mas em maior proporção no reator inoculado com lodo de reator UASB e usando como material suporte a espuma de poliuretano. Sequencialmente a este reator, foi acoplado um reator metanogênico, alimentado com efluente do reator acidogênico, estabilizado nas condições apresentadas, e operado com COV crescentes de 1, 2, 5, 7, 14, 17 e 26,5 gDQO.Lreator ${ }^{-1}$. dia ${ }^{-1}$ e consequente diminuição do TDH de 240, 96, 48, 32, 24, 16 e 12 horas. O reator acidogênico na $2^{\mathrm{a}}$ etapa foi operado por 417 dias consecutivos e COV de 120 g.DQO.Lreator ${ }^{1} \cdot \operatorname{dia}^{-1}$, produzindo hidrogênio continuamente, alcançado valores de produção bruta de $\mathrm{H}_{2}$ de 7,60 $\mathrm{LH}_{2}$.dia ${ }^{-1}$. O reator metanogênico foi operado por 251 dias consecutivos, produzindo metano e alcançado valores de produção bruta de $\mathrm{CH}_{4}$ de 5,90 $\mathrm{LCH}_{4} \cdot$ dia $^{-1}$. A eficiência de remoção de DQO do sistema de reatores foi de aproximadamente $90 \%$, com contribuição aproximadamente de $10 \%$ para o reator acidogênico e contribuição aproximadamente de $80 \%$ para o reator metanogênico. $\mathrm{O}$ reator acidogênico alcançou rendimento de produção de hidrogênio por $\mathrm{Kg}$ de melaço aplicado de $392 \mathrm{LH}_{2} . \mathrm{Kgmelaço}^{-1}$ e o reator metanogênico de $387 \mathrm{LCH}_{4} \cdot \mathrm{Kgmelaço}^{-1}$. Para finalidade de comparações e aplicabilidade, o ganho energético global do sistema de reatores de duas fases foi de aproximadamente 5,7 Kwh.Kgmelaço ${ }^{-1}\left(1,4 \mathrm{Kwh} . \mathrm{Kgmelaço}^{-1}\right.$ para o reator acidogênico e 4,3 Kwh.Kgmelaço ${ }^{-1}$ para o reator metanogênico). A produção continua de $\mathrm{H}_{2}$ obtida neste estudo está relacionada à associação das vias dos ácidos produtores de hidrogênio já consolidados pela literatura pertinente (acético e butírico) e pela produção de hidrogênio pela rota do ácido lático, devido a associação entre as comunidades de microrganismos estabelecidas no reator. O sequenciamento massivo MiSeq mostrou a seleção de diversos gêneros de microrganismos com redundância funcional e pertencentes principalmente aos Filos Firmicutes, Proteobacteria e Thermotogae, tais como Clostridium sensu stricto, Thermohydrogenium, Thermoanaerobacterium e Cellulosibacter (Firmicutes); Pseudomonas, Enterobacter, Shewanella e Petrobacter (Proteobacteria) e Fervidobacterium (Thermotogae). Microrganismos produtores de ácido lático também foram selecionados tais como: Lactobacillus, Leuconostoc, Sporolactobacillus e Trichococcus. Dos pontos de vista científico e tecnológico este estudo deu mais um passo para a compreensão dos bioprocessos envolvidos nos sistemas anaeróbios em dois estágios produzindo $\mathrm{H}_{2}$ e $\mathrm{CH}_{4}$ continuamente por longo período de tempo. 


\section{Palavras-chave:}

Produção de Hidrogênio. Produção de Metano. Processos Anaeróbios de Separação de Fases. Condição Termofílica. Indústria Sucroalcooleira. Melaço de Cana-de-açúcar. qPCR Gene Hidrogenase. Metagenômica MiSeq 


\begin{abstract}
VILELA, R.S. (2017). Hydrogen and Methane co-production from the sugarcane industry by-products at two-stages process anaerobic bioreactors under thermophilic condition. Thesis (Doctorate) - São Carlos School of Engineering, University of São Paulo, 164p.
\end{abstract}

Anaerobic digestion has shown as an interesting process for renewable energy production $\left(\mathrm{H}_{2}\right.$ and $\mathrm{CH}_{4}$ ), for a wide variety of organic compounds (carbon source). This study aimed to advance the understanding of a two-stage process anaerobic system (acidogenic bioreactor followed by methanogenic bioreactor) under thermophilic condition $\left(55^{\circ} \mathrm{C}\right)$ fed with molasses, a sugarcane industry by-product. The experiments were conducted at up-flow structured bed reactors and sugarcane molasses was diluted with tap water, to adjust the concentration to the wastewater treatment. At first stage two acidogenic reactors were operated in parallel to evaluate different source of inocula and support bed, to obtain continuous and stable hydrogen production. It was applied 2.5, 5 and 10 gCOD.L ${ }^{-1}$ resulting in OLR of 30, 60 and 120 g.COD.Lreactor ${ }^{-1}$.day $^{-1}$, with HRT fixed at 2 hours of hydrogenase gene was detected in both reactors but with higher number of copies of the gene in the reactor that showed higher hydrogen production: the reactor sed with sludge of UASB reactor and using polyurethane foam as support material. To this reactor was coupled a methanogenic reactor fed with effluent from acidogenic reactor and operated with increasing $\operatorname{OLR}(1,2,5,7,14,17$ e 26,5 gCOD.Lreactor ${ }^{1}$.day $\left.^{-1}\right)$ decreasing the HRT $(240,96,48,32,24,16$ and12 hours). The acidogenic reactor was operated during 471 days with OLR of 120 g.COD.Lreactor ${ }^{-1}$.day ${ }^{-1}$, with HRT fixed at 2 hours, with continuous hydrogen production with a gross production of $7.60 \mathrm{LH}_{2}$.day ${ }^{-1}$. The methanogenic reactor was operated for 251 days, with continuous methane production of up to 5.90 $\mathrm{LCH}_{4}$. day ${ }^{-1}$. The COD removal efficiency using the two-stage system was approximately $90 \%$, with $10 \%$ contribution by the acidogenic reactor and $80 \%$ contribution by the methanogenic reactor. The acidogenic reactor achieved hydrogen yield per $\mathrm{kg}$ of applied molasses equal to $392 \mathrm{LH}_{2} . \mathrm{Kgmolsses}^{-1}$. The methanogenic reactor achieved methane yield per $\mathrm{kg}$ of applied molasses equal to $387 \mathrm{LCH}_{4} \cdot \mathrm{Kgmolasses}^{-1}$. For comparison and applicability purposes, the overall energy yield using the two stage reactor system was approximately 5.7 Kwh.Kgmolasses ${ }^{-1}$ (Acidogenic reactor 1.4 Kwh.Kgmolasses ${ }^{-1}$ and Methanogenic reactor 4.3 Kwh.Kgmolasses ${ }^{-1}$ ). The continuous production of $\mathrm{H}_{2}$ obtained in this study is related to the association of the hydrogen producer acids pathway established by the relevant literature (acetic and butyric) and the hydrogen production by the lactic acid pathway due to the microorganism's association established in the reactor.Metagenomic analysis by MiSeq Plataform revealed that hydrogen production was due the selection of microorganisms with functional redundancy mainly of Phyla Firmicutes, Proteobacteria and Thermotogae, such as Clostridium sensu stricto, Thermohydrogenium, Thermoanaerobacterium, Cellulosibacter (Firmicutes; Pseudomonas, Enterobacter, Shewanella and Petrobacter (Proteobacteria) and Fervidobacterium (Thermotogae).. Genera of acid latic producers, such as Lactobacillus, Leuconostoc, Sporolactobacillus and Trichococcus, were also selected. . From the scientific and technological point of view this study has taken another step towards the understanding of bioprocesses involving two stage anaerobic systems for a long term continuous production of $\mathrm{H}_{2}$ and $\mathrm{CH}_{4}$. 


\section{Keywords}

Hydrogen Production. Methane Production. Anaerobic Two-Stage Process. Thermophilic Condition. Sugarcane Industry. Sugarcane Molasses. qPCR of Hydrogenase Gene. MiSeq Metagenomic. 


\section{LISTA DE FIGURAS}

Figura 1: Possibilidade teórica da biodigestão anaeróbia no sistema de separação de fases, a) Fase acidogênica, b) Fase metanogênica

Figura 2: Fluxograma simplificado do processo produtivo de usina sucroalcooleira 40

Figura 3: Fluxograma de configuração do experimento.

Figura 4: Layout estrutural do experimento; a) Layout reator anaeróbio de leito fixo estruturado, b) Estrutura e esquema experimental dos reatores na câmara termofílica $\left(55^{\circ} \mathrm{C}\right)$ 60

Figura 5: Materiais suporte utilizados a) Polietileno de baixa densidade; b) Hastes de espuma de poliuretano. 61

Figura 6: Monitoramento temporal da Carga Orgânica Volumétrica Aplicada (COV). 77

Figura 7: Monitoramento dos reatores acidogênicos - Etapa 1; a) Análise estatística de boxplot do monitoramento do $\mathrm{pH}$, b) Análise estatística de boxplot monitoramento da geração de ácidos totais, c) Análise estatística de boxplot monitoramento da carga de ácidos totais.

Figura 8: Monitoramento da remoção de DQO; a) Monitoramento temporal da remoção de DQO Bruta, b) Monitoramento temporal da remoção de DQO Solúvel 79

Figura 9: Monitoramento da conversão de carboidratos, a) Monitoramento temporal da conversão de carboidratos, b) Análise estatística de boxplot monitoramento da conversão global de carboidratos.

Figura 10: Produção de hidrogênio; a) Variação temporal da produção bruta de hidrogênio $\left(\mathrm{PBH}_{2}\right)$, b) Análise estatística de boxplot da $\mathrm{PBH}_{2}$, c) Variação temporal da produção volumétrica de hidrogênio $\left(\mathrm{PVH}_{2}\right)$, d) Análise estatística de boxplot da $\mathrm{PVH}_{2}$. 82

Figura 11: Análise estatística do coeficiente de correlação e ajuste polinomial de $2^{\mathrm{a}}$ ordem entre a produção de hidrogênio e carga orgânica volumétrica aplicada; a) Correlação $\mathrm{PBH}_{2} \mathrm{R} 1$ vs COV para R1, b) Correlação $\mathrm{PBH}_{2} \mathrm{R} 2$ vs COV para R2.

Figura 12: Análise estatística do coeficiente de correlação e ajuste polinomial de $2^{\mathrm{a}}$ ordem entre a produção de hidrogênio e a geração de ácidos toais gerados; a) Correlação $\mathrm{PBH}_{2} \mathrm{R} 1$ vs ácidos totais $\mathrm{R} 1$, b) Correlação $\mathrm{PBH}_{2} \mathrm{R} 2$ vs ácidos totais $\mathrm{R} 2$.

Figura 13: Análise estatística de boxplot da geração de ácidos orgânicos de interesse para a produção de hidrogênio; a) Ácidos orgânicos voláteis produzidos em R1, b) Ácidos orgânicos voláteis produzidos em R2, c) Concentração de ácidos efluente pela vazão aplicada em R1, d) Concentração de ácidos efluente pela vazão aplicada em R2. 
xviii

Figura 14: Composição do biogás nos reatores acidogênicos; a) Composição do biogás R1, b) Composição do biogás R2, c) Análise estatística de boxplot da composição do biogás reator R1, d) Análise estatística de boxplot da composição do biogás reator R2. 86

Figura 15: DGGE comparativos dos reatores acidogênicos; 1) Inóculo R1, 2) R1 COV 60 gDQO.Lreator ${ }^{-1} \cdot$ dia $^{-1}$, 3) R1 120 gDQO.Lreator ${ }^{-1} \cdot$ dia $^{-1}$, 4) Inóculo R2, 5) R2 COV 60 gDQO.Lreator ${ }^{-1} \cdot$ dia $^{-1}$; 6) R2 120 gDQO.Lreator ${ }^{-1} \cdot$ dia $^{-1}$. 88

Figura 16: Número de cópias rRNA 16S para Bactérias, amostras: 1) Inóculo R1, 2) R1 30 gDQO.Lreator ${ }^{-1} \cdot$ dia $^{-1}$, 3) R1 60 gDQO.Lreator ${ }^{-1} \cdot$ dia $^{-1}$, 4) R1 120 gDQO.Lreator ${ }^{-1} \cdot$ dia $^{-1}$, 5) Inóculo R2, 6) R2 30 gDQO.Lreator ${ }^{-1} \cdot$ dia $^{-1}$, 7) R2 60 gDQO.Lreator ${ }^{-1}$.dia ${ }^{-1}$, 8) R2 120 gDQO.Lreator ${ }^{-1} \cdot$ dia $^{-1}$.

Figura 17: Gene Fe hidrogenase (FHG). Amostras: 2) R1 30 gDQO.Lreator ${ }^{-1}$ dia $^{-1}$, 3) R1 60 gDQO.Lreator ${ }^{-1} \cdot$ dia $^{-1}$, 4) R1 120 gDQO.Lreator ${ }^{-1} \cdot$ dia $^{-1}$, 6) R2 30 gDQO.Lreator ${ }^{-1}$.dia ${ }^{-1}$, 7) R2 60 gDQO.Lreator ${ }^{-1}$.dia $\left.{ }^{-1}, 8\right)$ R2 120 gDQO.Lreator ${ }^{-1}$.dia ${ }^{-1}$.

Figura 18: Número de cópias do genes do inóculo e das amostras das diferentes cargas aplicadas ao reatores; a) R1 In - Inóculo, I - 30, II - 60 e III - 120 gDQO.Lreator ${ }^{-1}$.dia ${ }^{-1}$, b) R2 In - Inóculo, I - 30, II - 60 e III - 120 gDQO.Lreator ${ }^{-1} \cdot$ dia $^{-1}$. 90

Figura 19: Sequenciamento metagenômico dos Filos nos reatores USBR1 e USBR2 referente aos inóculos e cada COV.

Figura 20: Sequenciamento metagenômico dos Gêneros nos reatores USBR1 e USBR2 referente aos inóculos e cada COV.

Figura 21: Monitoramento da carga orgânica volumétrica aplicada (COV) ao reator acidogênico; a) Monitoramento temporal da COV, b) Análise estatística de boxplot da variação da COV.

Figura 22: Monitoramento do pH; a) Variação temporal do pH afluente e efluente, b) Análise estatística de boxplot da variação de $\mathrm{pH}$.

Figura 23: Monitoramento da geração de ácidos totais; a) Variação temporal da geração de ácidos totais, b) Análise estatística de boxplot da geração de ácidos totais, c) Carga de ácidos no efluente, d) Análise estatística de boxplot da carga de ácidos no efluente 100

Figura 24: Monitoramento da remoção de DQO reator acidogênico; a) Monitoramento temporal da remoção de DQO, b) Análise estatística de boxplot da variação da DQO, c) Análise estatística de boxplot da porcentagem de remoção de DQO. 101

Figura 25: Monitoramento da conversão de carboidratos reator acidogênico; a) Monitoramento temporal da conversão de carboidratos, b) Análise estatística de boxplot da variação dos carboidratos, c) Análise estatística de boxplot da porcentagem de conversão de carboidratos.

Figura 26: Monitoramento da vazão do biogás gerado; a) Variação temporal da produção de biogás, b) Análise estatística de boxplot da porcentagem da geração de biogás. 104 
Figura 27: Monitoramento da composição do Biogás; a) Variação temporal da porcentagem da composição do biogás, b) Análise estatística de boxplot da porcentagem da composição do biogás.

Figura 28: Monitoramento da produção de hidrogênio; a) Variação temporal da produção bruta de hidrogênio $\left(\mathrm{PBH}_{2}\right)$, b) Análise estatística de boxplot da produção bruta de hidrogênio $\left(\mathrm{PBH}_{2}\right)$. 106

Figura 29: Monitoramento da produção de hidrogênio; a) Variação temporal da produção volumétrica de hidrogênio $\left(\mathrm{PVH}_{2}\right)$, b) Análise estatística de boxplot da produção volumétrica de hidrogênio $\left(\mathrm{PVH}_{2}\right)$. 106

Figura 30: Análise estatística do coeficiente de correlação da produção bruta de hidrogênio $\left(\mathrm{PBH}_{2}\right)$; a) Correlação $\mathrm{PBH}_{2}$ vs $\mathrm{pH}$, b) Correlação $\mathrm{PBH}_{2}$ vs ácidos totais, c) Correlação $\mathrm{PBH}_{2}$ vs $\mathrm{COV}$, d) Correlação $\mathrm{PBH}_{2}$ vs \% Remoção de $\mathrm{DQO}$, e) Correlação $\mathrm{PBH}_{2}$ vs $\mathrm{COV}$ carboidratos, f) Correlação $\mathrm{PBH}_{2}$ vs \% conversão de carboidratos. 108

Figura 31: Monitoramento do rendimento de mol de hidrogênio por mol de carboidrato convertido $\left(\mathrm{YH}_{2}\right)$; a) Análise temporal do $\mathrm{YH}_{2}$, b) Análise estatística de boxplot do $\mathrm{YH}_{2} \ldots 110$

Figura 32: Monitoramento do rendimento da produção bruta de hidrogênio por litro de melaço diluído $\left(\mathrm{YPBH}_{2}\right)$; a) Análise temporal da $\mathrm{YPBH}_{2}$, b) Análise estatística de boxplot $\mathrm{YPBH}_{2}$.

Figura 33: Monitoramento do rendimento da produção volumétrica de hidrogênio por litro de melaço diluído $\left(\mathrm{YPVH}_{2}\right)$; a) Análise temporal da $\mathrm{YPVH}_{2}$, b) Análise estatística de boxplot $\mathrm{YPVH}_{2}$

Figura 34: Monitoramento do rendimento da produção de hidrogênio por $\mathrm{Kg}$ de melaço aplicado $\left(\mathrm{ZPBH}_{2}\right)$; a) Análise temporal da $\mathrm{ZPBH}_{2}$, b) Análise estatística de boxplot $\mathrm{ZPBH}_{2}$.

Figura 35: Monitoramento da COVm; a) Monitoramento temporal da COVm, b) Análise estatística de boxplot da COVm. 117

Figura 36: Monitoramento e controle do $\mathrm{pH}$; a) Monitoramento e controle temporal do $\mathrm{pH}$, b) Análise estatística de boxplot do monitoramento do $\mathrm{pH}$, c) monitoramento global do $\mathrm{pH}$.... 118

Figura 37: Monitoramento da geração de alcalinidade pela relação AI/AP; a) Monitoramento global da relação AI/AP, b) Monitoramento temporal da relação AI/AP, c) Análise estatística de boxplot da relação AI/AP. 119

Figura 38: Análise estatística de boxplot da eficiência da remoção global de DQO; a) análise da eficiência da remoção global de DQO, b) Análise da porcentagem da eficiência da remoção global de DQO. 119

Figura 39: Monitoramento da eficiência da remoção de DQO por fases; a) Monitoramento temporal da eficiência remoção de DQO, b) Análise estatística de boxplot da eficiência de 
remoção de DQO, c) Análise estatística de boxplot da porcentagem da eficiência da remoção de DQO.

Figura 40: Monitoramento por fases da composição do biogás

Figura 41: Análise estatística de boxplot da porcentagem de metano no biogás

Figura 42: Monitoramento da produção bruta de metano $\left(\mathrm{PBCH}_{4}\right)$; a) Monitoramento temporal da $\mathrm{PBCH}_{4}$, b) Análise estatística de boxplot da $\mathrm{PBCH}_{4}$

Figura 43: Monitoramento da produção volumétrica de metano $\left(\mathrm{PVCH}_{4}\right)$; a) Monitoramento temporal da $\left.\mathrm{PVCH}_{4}, \mathbf{b}\right)$ Análise estatística de boxplot da $\mathrm{PVCH}_{4}$

Figura 44: Análise estatística do coeficiente de correlação da produção bruta de metano $\left(\mathrm{PBCH}_{4}\right)$; a) Correlação $\mathrm{PBCH}_{4}$ vs pH efluente, b) Correlação $\mathrm{PBCH}_{4}$ vs relação AI/AP, c) Correlação $\mathrm{PBCH}_{4}$ vs $\mathrm{COVm}$, d) Correlação $\mathrm{PBCH}_{4}$ vs DQO afluente.

Figura 45: Coeficiente de correlação entre $\mathrm{PBCH}_{4}$ e os valores de DQO efluentes obtidos; a) $\mathrm{PBCH}_{4}$ vs DQO efluente, b) $\mathrm{PBCH}_{4}$ vs \% de DQO removida. 126

Figura 46: Monitoramento do rendimento de metano por gDQO removida $\left(\mathrm{YCH}_{4}\right)$; a) Monitoramento temporal do rendimento de metano gDQO removida $\left(\mathrm{YCH}_{4}\right)$, b) análise estatística de boxplot do rendimento de metano gDQO removida $\left(\mathrm{YCH}_{4}\right)$. 126

Figura 47: Monitoramento do rendimento de metano por $\mathrm{kg}$ de melaço $\left(\mathrm{ZCH}_{4}\right)$; a) Monitoramento temporal do rendimento de metano por $\mathrm{kg}$ de melaço $\left(\mathrm{ZCH}_{4}\right)$, b) análise estatística de boxplot do rendimento de metano por $\mathrm{kg}$ de melaço $\left(\mathrm{ZCH}_{4}\right)$. 127

Figura 48: Análise estatística de boxplot dos ácidos orgânicos voláteis (AOV) afluente 131

Figura 49: Análise estatística de boxplot produtos intermediários gerados no reator acidogênico. 132

Figura 50: Visão simplificada das principais rotas metabólicas envolvendo a produção de $\mathrm{H}_{2}$ por Clostridium spp

Figura 51: Produtos intermediários efluente reator metanogênico - Ácidos Orgânicos Voláteis (AOV) a) AOV Fases I e II, b) AOV Fases III, IV e V, c) AOV Fases VI e VII. 134

Figura 52: Fluxograma do processo produtivo do açúcar e álcool com a produção de bioenergia a partir da vinhaça, desviando parte do melaço para a codigestão a fim de manter o reator anaeróbio em operação continua na entressafra.

Figura 53: Panorama de geração de metano e hidrogênio a partir de melaço de cana-de-açúcar, a partir de dados de desempenho gerados em reatores anaeróbios de leito fixo em escala de bancada, As produções de energia foram calculadas de acordo com Kongjan et al. (2013). 139 
Figura 54: Exemplo de interpretação de coeficiente de correlação. a) coeficiente de correlação positiva $P=1, \mathbf{b})$ coeficiente de correlação negativa $P=-1, \mathbf{c})$ coeficiente de correlação nula $P=0$ 163

Figura 55: Exemplo do formato e interpretação do diagrama de boxplot. 164 
xxii 


\section{LISTA DE TABELAS}

Tabela 1: Resumo das estratégias adotadas no controle operacional de reatores de duas fases

Tabela 2: Estratégias e hipóteses adotadas para este estudo, para manutenção estável do sistema de duas fases

Tabela 3: Condições operacionais dos reatores acidogênicos - Etapa 1

Tabela 4: Condições operacionais impostas ao reator metanogênico 58

Tabela 5: Características dos materiais suportes utilizados 61

Tabela 6: Caracterização do melaço e da vinhaça de cana-de-açúcar.... 64

Tabela 7: Controle do $\mathrm{pH}$ para as fases metanogênicas 66

Tabela 8: Valores obtidos no monitoramento dos parâmetros afluente e efluente de R1 e R2 na primeira fase de operação com carga de 30gDQO.Lreator ${ }^{-1} \cdot$ dia $^{-1}$.

Tabela 9: Valores obtidos no monitoramento dos parâmetros afluente e efluente de R1 e R2 na primeira fase de operação com carga de 60gDQO.Lreator ${ }^{-1} \cdot$ dia $^{-1}$.

Tabela 10: Valores obtidos no monitoramento dos parâmetros afluente e efluente de R1 e R2 na primeira fase de operação com carga de 120gDQO.Lreator ${ }^{-1} \cdot \mathrm{dia}^{-1}$.

Tabela 11: Comparativo das produções de hidrogênio $\left(\mathrm{PBH}_{2}\right.$ e $\left.\mathrm{PVH}_{2}\right)$ entre os reatores acidogênicos

Tabela 12: Avaliação dos Produtos Intermediários (valores de porcentagem de ácidos por fases)

Tabela 13: Valores de composição do biogás nos reatores acidogênicos .87

Tabela 14: Índices aplicados à técnica de DGGE. 88

Tabela 15: Resumo do monitoramento das variáveis do reator acidogênico 103

Tabela 16: Monitoramento e composição o biogás gerado ao longo do experimento 105

Tabela 17: Resumo das produções de hidrogênio $\left(\mathrm{PBH}_{2}\right.$ e $\left.\mathrm{PVH}_{2}\right)$ 107

Tabela 18: Tabela comparativa de trabalhos realizados com objetivo de produção de $\mathrm{H}_{2} \ldots . .107$

Tabela 19: Resumo da correlação da produção bruta de hidrogênio com as faixas de valores dos parâmetros aplicados 
xxiv

Tabela 20: Comparativo dos rendimentos de hidrogênio por litro de melaço aplicado 113

Tabela 21: Rendimento da produção de hidrogênio por kg de melaço aplicado ..... 114

Tabela 22: Visão geral do desempenho do reator acidogênico. 115

Tabela 23: Fases avaliadas na metanogênese 116

Tabela 24: Valores obtidos nas produções de metano, $\mathrm{PBCH}_{4}$ e $\mathrm{PVCH}_{4}$. 123

Tabela 25: Visão geral do desempenho do reator metanogênico. 129

Tabela 26: DQO relativa dos ácidos orgânicos voláteis no afluente 130

Tabela 27: Ganho energético do sistema de reatores combinados. 141 


\section{LISTA DE SÍMBOLOS E ABREVIATURAS}

${ }^{\circ} \mathrm{C}$ - Graus Celsius

${ }^{\circ} \mathrm{C} . \mathrm{m}^{-1}-$ Graus Celsius por minuto

$\mu \mathrm{L}-$ Microlitros

$\mathrm{AB}$ - Alcalinidade a bicabornato

AFBR - Reator Anaeróbio de Leito Fluidizado (Anaerobic Fluidized Bed Reactor)

AFSBR - Reator Anaeróbio de Leito Fixo Estruturado (Anerobic Fixed-Structured Bed Reactor)

AI - Alcalinidade intermediária

AI:AP - Relação alcalinidade intermediária e alcalinidade parcial

AnSBBR - Reator Anaeróbio Operado em Batelada Sequencial com Biomassa Imobilizada em Suporte Inerte (Anaerobic Sequencing Batch Biofilm Reactor)

AP - Alcalinidade parcial

APBR - Reator Anaeróbio de Leito Fixo Empacotado (Anaerobic Packed Bed Reactor)

AT - Alcalinidade total

AVT - Ácidos voláteis totais

$\mathrm{CH}_{4}-$ Gás metano

$\mathrm{CNTP}$ - Condições normais de temperatura e pressão $\left(0^{\circ} \mathrm{C}\right.$ e $\left.1 \mathrm{~atm}\right)$

CO - Carga orgânica

$\mathrm{CO}_{2}$ - Gás dióxido de carbono

COA - Carga orgânica aplicada

COV - Carga orgânica volumétrica aplicada

COVm - Carga orgânica volumétrica aplicada ao reator metanogênico

CSRT - Continuous stirred-tank reactor (reator tanque agitado contínuo)

$\mathrm{dH}_{2} \mathrm{O}$ - Água ultra destilada 
DIC - Detector de ionização de chama

DNA - deoxyribonucleic acid (ácido desoxirribonucleico)

DQO - Demanda química de oxigênio

EDTA - Ethylenediamine tetraacetic acid (ácido etilenodiamino tetra-acético)

g. $\mathrm{L}^{-1}-$ Gramas por litro

g.m $\mathrm{m}^{-2}$ - gramas por metro quadrado

gDQO.dia ${ }^{-1}$ - gramas de DQO por dia

gDQO.Lreator ${ }^{-1} \cdot \mathrm{dia}^{-1}\left(\mathrm{gDQO} \cdot \mathrm{Lr}^{-1} \cdot \mathrm{d}^{-1}\right)$ - gramas de DQO por litro de reator por dia glic. $\mathrm{L}^{-1}-$ glicose por litro

$\mathrm{h}-$ horas

$\mathrm{H}_{2}$ - Gás hidrogênio

HAc - Ácidos voláteis na forma de acetato

HFB - Reator Fermentação de Hidrogênio (Hydrogen Fermentation Bioreactor)

kgDQO.L . $^{-1} \cdot \mathrm{dia}^{-1}$ - Quilogramas de DQO por litro por dia

kgDQO.m ${ }^{-3} \cdot \operatorname{dia}^{-1}$ - Quilogramas de DQO por metro cúbico por dia

kgSVT.m ${ }^{-3} \cdot$ dia $^{-1}$ - Quilograma por sólidos voláteis totais por metro cúbico por dia

KWh - Quilowatt hora

KWh.Kgmelaço-1 - Quilowatt hora por quilograma de melaço aplicado

L - Litros

$\mathrm{LH}_{2} . \mathrm{kgSV}^{-1}$ - Litro de hidrogênio por quilograma de sólidos voláteis

$\mathrm{m} . \mathrm{v}^{-1}-$ mols por volume

mgDQO.L ${ }^{-1}$ - miligramas de DQO por litro

$\mathrm{mL}-$ mililitros

mm - milímetros

$\mathrm{molH}_{2} \cdot \mathrm{mol}^{-1}$ lactato - Mols de hidrogênio por mol de Lactato 
$\mathrm{molH}_{2} \mathrm{~mol}^{-1}$ sacarose - Mols de hidrogênio por mol de sacarose

$\mathrm{N}_{2}-$ Gás nitrogênio

Nm - Nanômetros

PCR - Reação da cadeia da polimerase

$\mathrm{pH}$ - Potencial hidrogeniônico

qPCR - PCR em tempo real

RNA - ribonucleic acid (ácido ribonucleico)

rRNA $16 \mathrm{~S}$ - RNA ribossomal 16s

SSV - Sólidos suspensos voláteis

TC - Tempo de ciclo

TDH - Tempo de detenção hidráulica

UASB - upflow anaerobic sludge Blanket reactor (reator anaeróbico de lodo de fluxo ascendente)

$\mathrm{YPBCH}_{4}-$ Rendimento da produção bruta de Metano

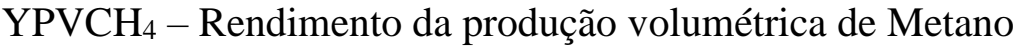

$\mathrm{YPBH}_{2}-$ Rendimento da produção bruta de Hidrogênio

$\mathrm{YPVH}_{2}-$ Rendimento da produção volumétrica de Hidrogênio

$\mathrm{ZPBCH}_{4}-$ Rendimento da produção de Metano por $\mathrm{Kg}$ de melaço

$\mathrm{ZPBH}_{2}-$ Rendimento da produção de Hidrogênio por Kg de melaço

$\mathrm{WPBCH}_{4}-$ Rendimento da produção de Metano em KWh por Kg de melaço

$\mathrm{WPBH}_{2}-$ Rendimento da produção de Hidrogênio por KWh por Kg de melaço 
xxviii 


\section{SUMÁRIO}

RESUMO.

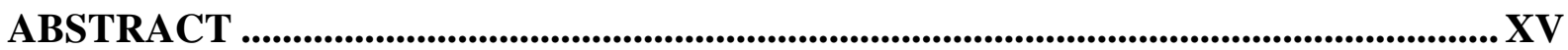

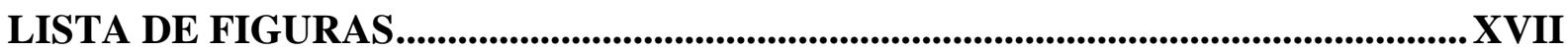

LISTA DE TABELAS ................................................................................................. XXIII

LISTA DE SÍMBOLOS E ABREVIATURAS................................................................ XXV

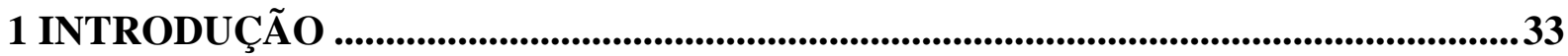

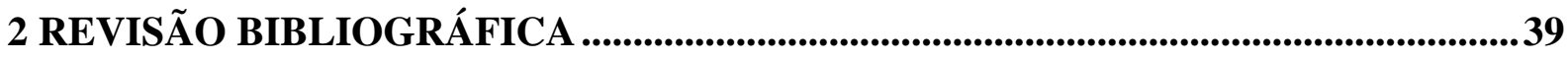

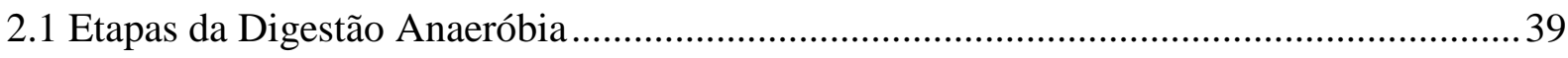

2.2 Melaço da Cana-de-Açúcar: Processo Produtivo, Composição e Aplicabilidade............... 40

2.3 Fatores Limitantes ao Bioprocesso da Digestão Anaeróbia em Sistema de Duas Fases.... 42

2.4 Estratégias de Controle Operacional em Sistema de Reatores de Duas Fases ................... 43

2.5 Técnicas de Biologia Molecular para Estudo em Reatores Anaeróbios ............................49

2.5.1 Denaturing Gradient Gel Electrophoresis (DGGE) .....................................................49

2.5.2 Sequenciamento do Metagenoma Microbiano ...........................................................50

2.5.3 Técnicas de PCR (Polymerase Chain Reaction) e PCR em Tempo Real (qPCR) ..........51

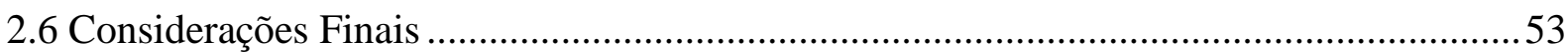

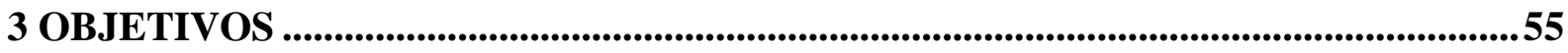

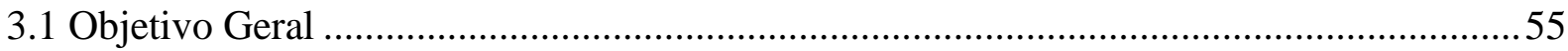

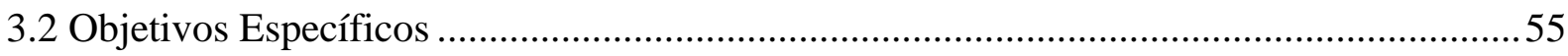

4 INSTALAÇÕES, TÉCNICAS EXPERIMENTAIS E MÉTODOS ANALÍTICOS......57

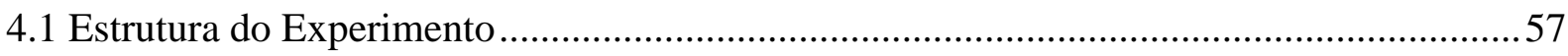

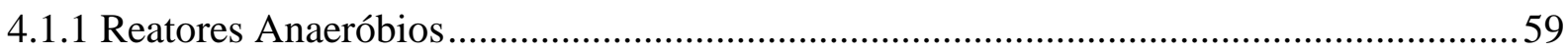

4.1.2 Materiais Suporte dos Reatores Acidogênicos .............................................................. 60

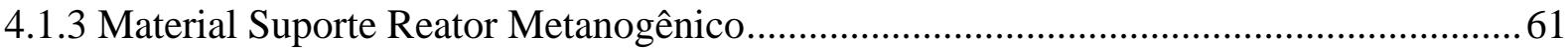

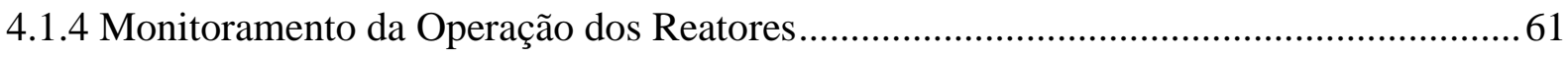




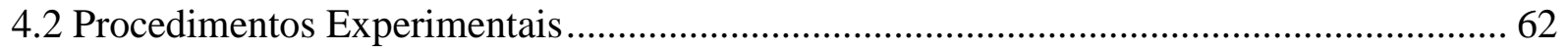

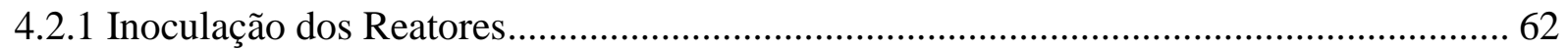

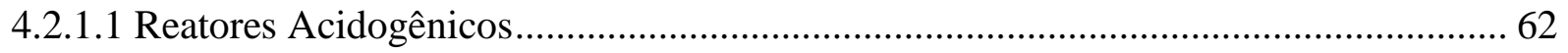

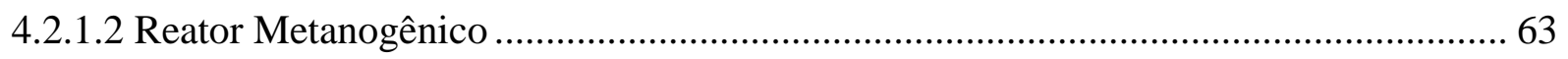

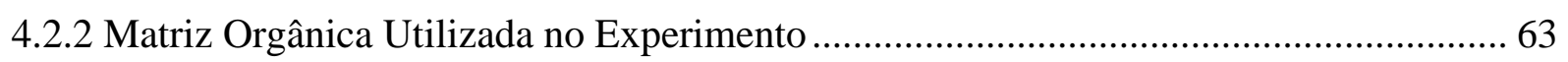

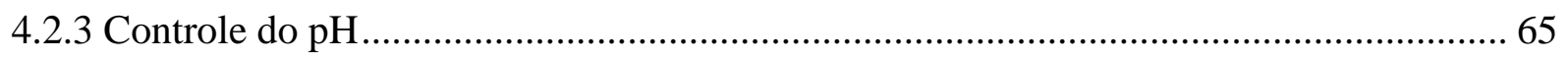

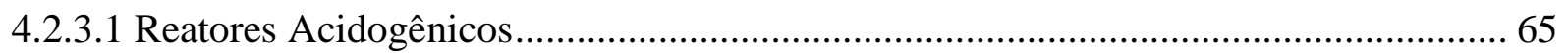

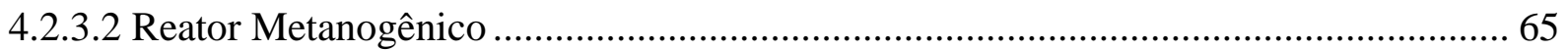

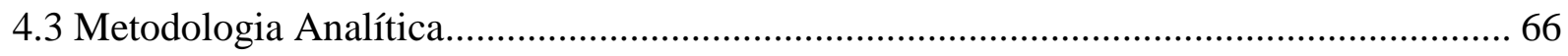

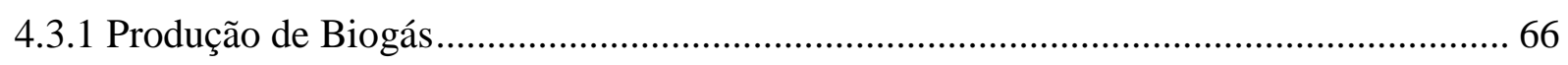

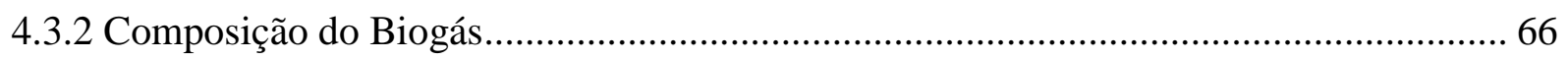

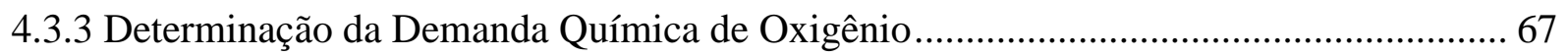

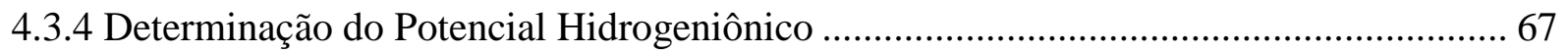

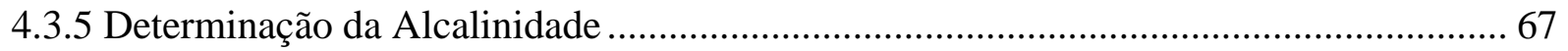

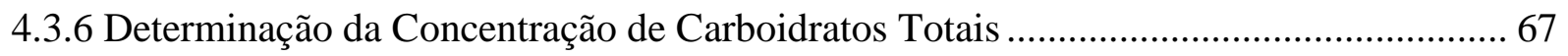

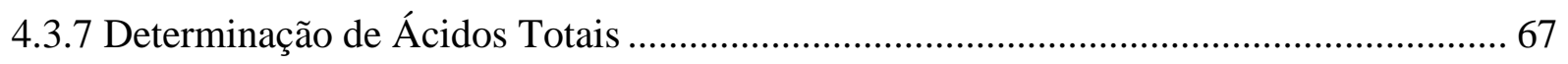

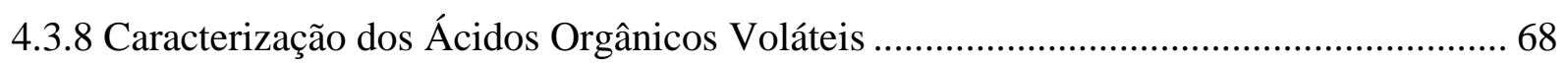

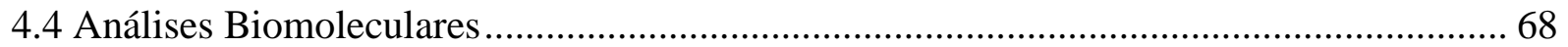

4.4.1 Amostragem da Biomassa para Análises Biomoleculares ….......................................... 68

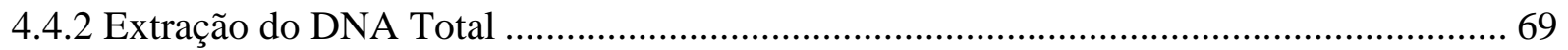

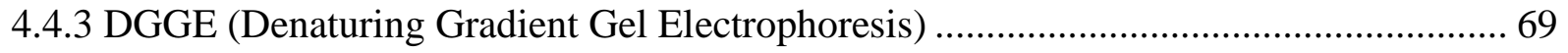

4.4.4 Amplificação dos Genes por PCR (Polimerase Reaction Chain) .................................. 70

4.4.5 Quantificação dos Genes por PCR em Tempo Real (qPCR) ........................................ 70

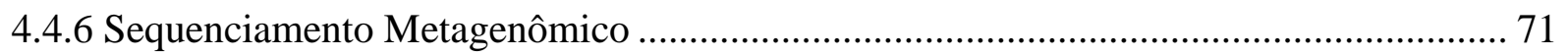

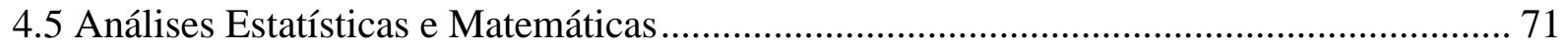

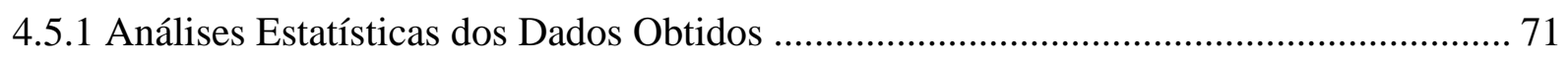

4.5.2 Análises Matemáticas do Desempenho dos Reatores ................................................. 72

5 APRESENTAÇÃO E DISCUSSÃO DOS RESULTADOS................................................ 77

5.1 Etapa 1 - Análise e Comparação dos Reatores Acidogênicos .......................................... 77

5.1.1 Análise Comparativa do Desempenho dos Reatores Acidogênicos .............................. 77

5.1.2 Análise Comparativa Biomoleculares dos Reatores Acidogênicos ............................... 87

5.1.2.1 Perfil da Comunidade de Bactéria pela Técnica de PCR-DGGE ............................... 87

5.1.2.2 Análise Biomolecular pela Técnica de PCR em tempo real (qPCR) .......................... 89

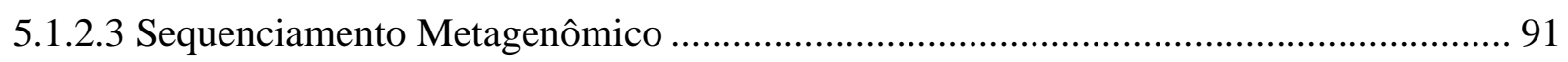

5.1.3 Conclusões Parciais Sobre Análise Comparativa dos Reatores Acidogênicos ............... 96 
5.2 Etapa 2 - Análise do Sistema de Reatores Combinados .................................................. 98

5.2.1 Análise do Desempenho do Reator Acidogênico ........................................................ 98

5.2.2 Análise do Desempenho do Reator Metanogênico Instalado Sequencialmente ao Reator

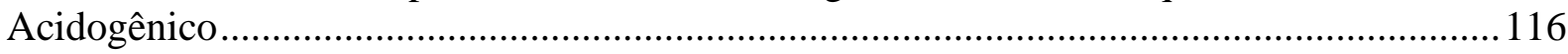

5.2.3 Avaliação dos Ácidos Orgânicos Voláteis no Sistema de Reatores Combinados.......... 130

5.2.4 Abordagem Geral do Sistema de Reatores Combinados ............................................ 136

5.2.5 Abordagem sobre o Balanço Energético do Sistema Combinado ................................. 138

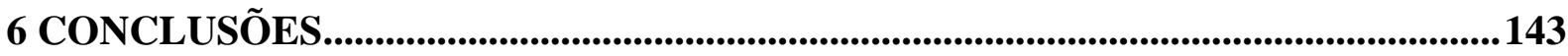

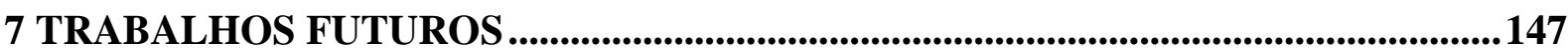

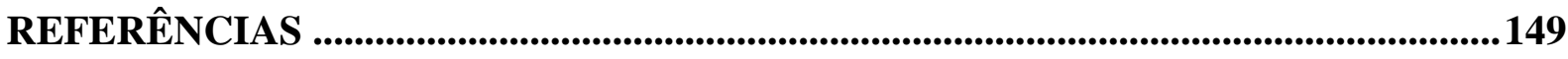

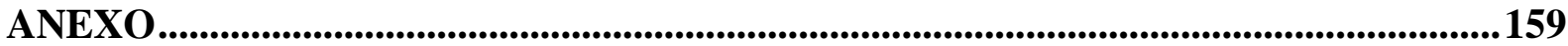

Obtenção das Curvas para Gases - Cromatógrafo Shimadzu GC-2010 ............................... 159

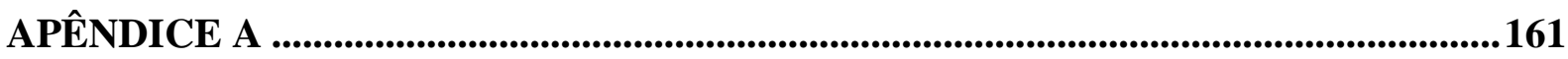

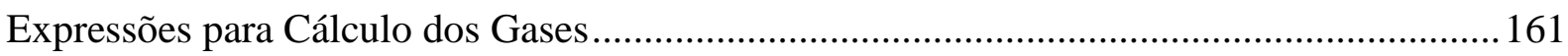

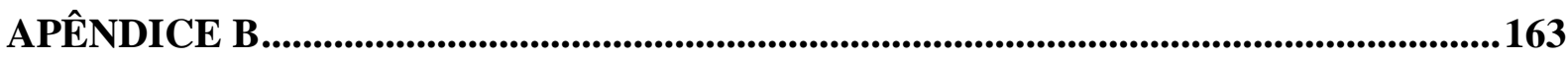

Interpretações das Expressões Estatísticas dos Dados Obtidos.............................................. 163

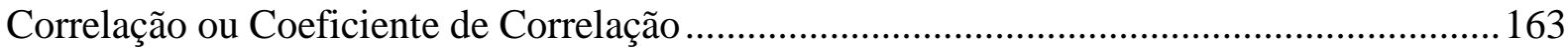

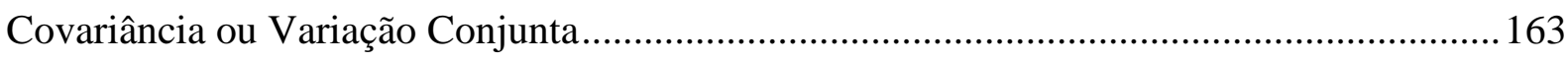

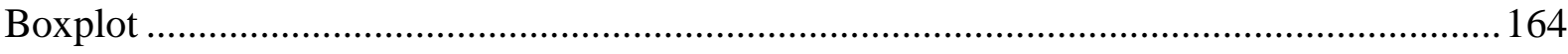


xxxii 


\section{INTRODUÇÃO}

Com conhecimento consolidado pela literatura pertinente, a digestão anaeróbia representa um sistema ecologicamente balanceado, em que cada microrganismo envolvido tem sua função primordial e essencial na conversão da matéria orgânica complexa a produtos finais de interesse econômico e ambiental. É um processo altamente interessante uma vez que pode ser fonte de produção de energia renovável $\left(\mathrm{H}_{2}\right.$ e $\left.\mathrm{CH}_{4}\right)$, se considerando a ampla variedade de compostos orgânicos que podem ser utilizados pelos microrganismos envolvidos, devido a versatilidade dos mesmos.

Aliado a isso, a crescente necessidade de fontes de energias renováveis, juntamente com o aparecimento de novas tecnologias anaeróbias, utilizadas para mitigação de efeitos ambientais do lançamento de efluentes a custos reduzido de consumo energético, colocam esses processos em destaque. Órgãos governamentais e a iniciativa privada em países desenvolvidos da Europa, bem como em países emergentes (Brasil, China, Índia e outros) vislumbram e apoiam essa alternativa de ampliação da matriz energética.

Dos pontos de vista ambiental, econômico e energético no Brasil, se abrem perspectivas otimistas para a geração de novas tecnologias para a obtenção de energia combinada com adequação dos efluentes industriais gerados. A partir desse cenário, a digestão anaeróbia ao usar diferentes fontes de carbono provenientes de águas residuárias industriais, tem sido amplamente estudada pelo ponto de vista da recuperação de subprodutos de interesse econômico, como o hidrogênio e o metano no Laboratório de Processos Biológicos (LPB) da Escola de Engenharia de São Carlos da Universidade de São Paulo (EESC/USP).

Recentemente pode-se citar alguns trabalhos para recuperação de subprodutos nos Anais do V Seminário do Projeto Temático (2015) "Produção de Bioenergia no Tratamento de Águas Residuárias e Adequação Ambiental dos Efluentes e Resíduos Gerados”, por exemplo Soares et al. estudaram a hidrólise do bagaço da cana-de-açúcar para a produção de hidrogênio; Gomes e colaboradores estudaram a produção de hidrogênio a partir de manipueira (água residuária do processo de fabricação de farinha de mandioca); Del Nery et al. estudaram a recuperação de metano a partir da vinhaça da cana-de-açúcar (água residuária proveniente da produção de açúcar e álcool) em reatores UASB piloto, entre outros autores. 
Outro fator inovador dos trabalhos realizados sem dúvida fica a cargo da tecnologia de separação de fases do processo global da digestão anaeróbia para a produção conjunta de hidrogênio e metano a partir de águas residuárias industriais. Como descrito anteriormente, o processo de digestão anaeróbia envolve dois grupos principais de consórcios de microrganismos: as bactérias acidogênicas, que decompõem os substratos principalmente em $\mathrm{H}_{2}, \mathrm{CO}_{2}$ e acetato; e as arquéias metanogênicas, que convertem o acetato, $\mathrm{o}_{2}$ e o $\mathrm{CO}_{2}$ em $\mathrm{CH}_{4}$.

A produção de $\mathrm{H}_{2}$ requer a interrupção do processo de digestão anaeróbia, pois o $\mathrm{H}_{2}$ constitui-se em um intermediário altamente energético e requisitado pelos microrganismos envolvidos. A partir desta premissa, o sistema de separação de fases permite a extração de hidrogênio em primeiro estágio e metano em segundo estágio.

Teoricamente isto representa a separação física dos microrganismos. A operação de sistemas anaeróbios de dois estágios, permite a manutenção das condições ambientais adequadas para cada população em cada reator.

O processo anaeróbio de duas fases é baseado nas diferenças significativas entre os grupos da acidogênese $\left(\mathrm{H}_{2}\right)$ e da metanogênese $\left(\mathrm{CH}_{4}\right)$ em termos de fisiologia, necessidades nutricionais, cinética de crescimento e a sensibilidade às condições ambientais impostas. Para tanto, os dois grupos distintos de microrganismos são enriquecidos separadamente em dois estágios, por intervenções de engenharia, as quais consistem em acoplar um reator metanogênico subsequentemente ao reator acidogênico.

O tratamento anaeróbio em dois estágios propicia a melhoria da eficiência, aumenta a estabilidade e flexibilidade do processo, permite a aplicação de altas cargas orgânicas e consequentemente maior produção de energia, entretanto ainda são pouco explorados comercialmente, comparado com o processo anaeróbio unitário (NASR et al., 2012).

A Figura 1 ilustra teoricamente a biodigestão anaeróbia no sistema de separação de fases e permite visualizar as fases inibidas e/ou inativas de cada etapa. 

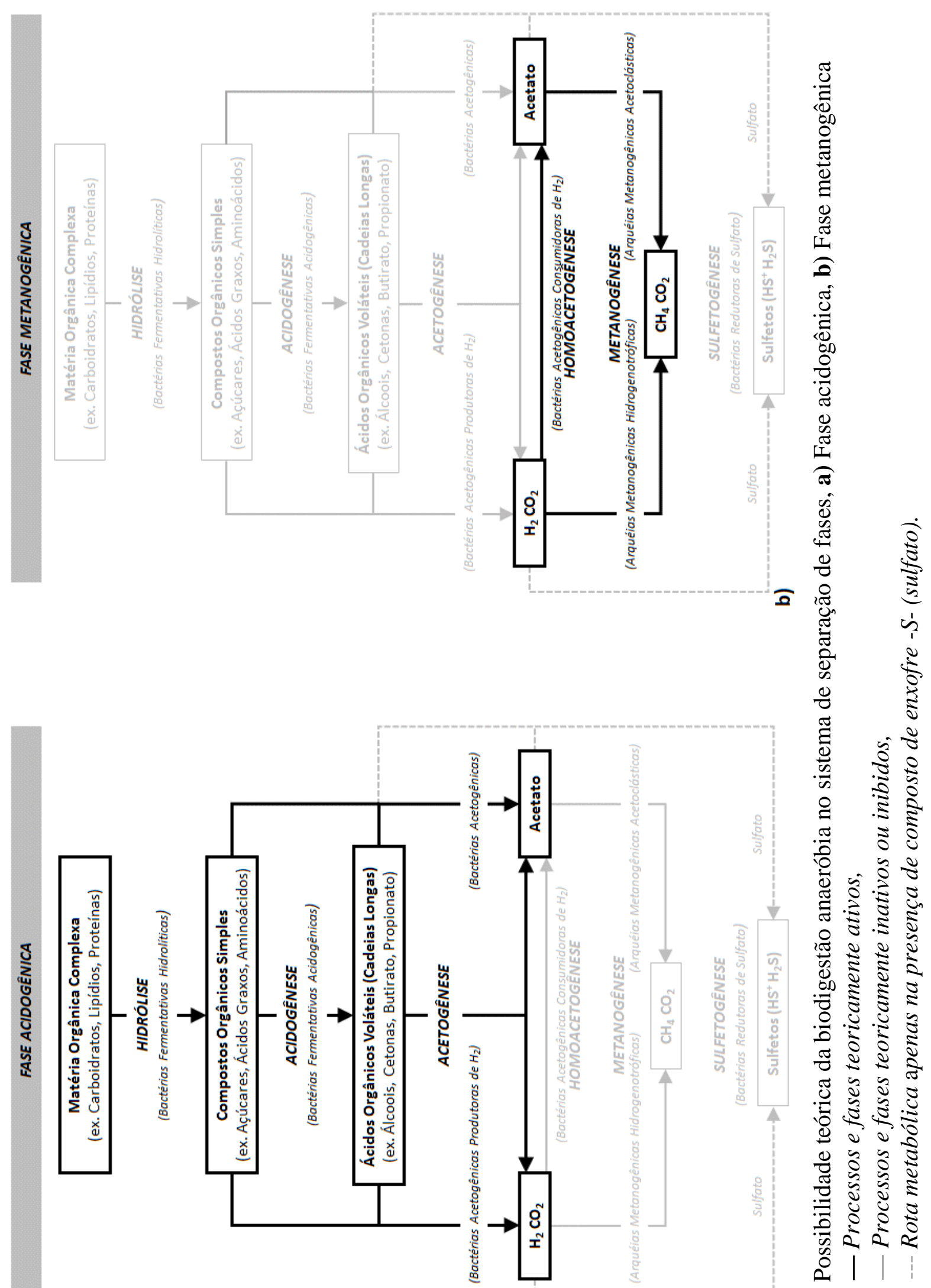

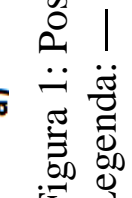


No entanto as dificuldades inerentes ao controle das fases acidogênica e metanogênica em reatores separados estão associadas ao sintrofismo intrínseco da digestão anaeróbia (produção e consumo de ácidos orgânicos, sob baixa pressão parcial de hidrogênio), o controle do pH e das vias metabólicas são fatores que merecem atenção.

A elevada concentração de carboidratos, em determinadas águas residuárias (caso da vinhaça), representa risco potencial de acidificação em reatores de fase única, pois requer controle estreito da alcalinidade, que ocorre ao menos parcialmente pela integração dos processos envolvidos. Da mesma forma, em sistemas de fases separadas, o controle da fase ácida e do pH na fase metanogênica precisa ser rigorosamente controlado, com necessidade de interferência externa. A comparação entre o consumo de álcali em ambos os casos é necessária para escolha da alternativa a ser adotada.

O conhecimento das diretrizes para utilização de sistemas de tratamento de águas residuárias de elevada concentração e ricas em carboidratos em sistemas em duas fases carece de estudo mais aprofundados para sua potencial utilização em sistemas de tratamento em plantas industriais, afim de obter adequação dos efluentes gerados e energia de baixo custo, ambientalmente sustentável e renovável.

Um dos desafios apontados é o preenchimento das lacunas existentes a respeito do controle dos bioprocessos envolvidos na digestão anaeróbia em sistema de duas fases, referentes as rotas metabólicas, estrutura, dinâmica e ecologia dos organismos envolvidos. Neste contexto, parâmetros de monitoramento do bioprocesso podem auxiliar a elucidar e preencher algumas delas.

Estudos relacionados com o sistema de digestão anaeróbia de duas fases para a aplicação futura da tecnologia nas usinas sucroalcooleiras foram desenvolvidos por Peixoto (2011), e Ferraz (2013), com avanços importantes na produção biológica de hidrogênio e metano a partir da vinhaça da cana-de-açúcar.

Entretanto, existem alguns problemas como a sazonalidade na produção da vinhaça e as flutuações da quantidade e qualidade gerada, prejudicando a avaliação do desempenho dos reatores e a projeção das quantidades de biogás gerados, o que representa um desafio para a introdução comercial da biodigestão da vinhaça, pois a comunidade microbiana é fortemente afetada pelo período da entressafra o que implica em longo período de repartida dos reatores até o restabelecimento do processo anaeróbio. 
Desse modo há necessidade de estudos sobre utilização de fontes de carbono adicionais, preferencialmente provenientes da própria usina, para a manutenção eficaz da tecnologia do sistema de duas fases nos reatores anaeróbios no período da entressafra com vistas a adequação de efluentes e a recuperação de energias renováveis de forma contínua.

Diante do exposto, o melaço de cana-de-açúcar pode ser uma fonte de carbono de baixo custo para manutenção da produção fermentativa contínua de hidrogênio e metano, em reatores anaeróbios operados por longo período de tempo nas plantas sucroalcooleiras; justificado devido à presença de grande quantidade de açúcares fermentescíveis, qual constitui uma boa fonte de carbono para o metabolismo microbiano (WALISZEWSKI et al., 1997).

São escassos os relatos na literatura pertinente sobre a utilização do melaço como única fonte de carbono para a produção contínua de hidrogênio e metano por longo período de tempo nos sistemas de duas fases operados em condições termofílicas $\left(55^{\circ} \mathrm{C}\right)$. Assim, justifica-se a necessidade de estudos relacionados ao bioprocesso do sistema de duas fases, alimentados com fontes de carbono complexos para o avanço do conhecimento.

Estudos fundamentais, baseados no conhecimento das rotas metabólicas e microrganismos envolvidos contribuem em grande medida para o entendimento das estratégias para a geração de bioenergia a partir de substratos complexos. Para isso, o uso das técnicas de biologia molecular pode auxiliar na compreensão dos resultados obtidos no monitoramento dos reatores operados em duas fases, permitindo avaliar, estudar e contribuir para entender a estrutura e dinâmica microbiana e utilizar o conhecimento no controle e avaliação da potencialidade do processo.

Diante do exposto, com este estudo deseja-se avançar na compreensão do sistema de reatores anaeróbios de duas fases operados em condições termofílicas $\left(55^{\circ} \mathrm{C}\right)$, alimentados com melaço da cana-de-açúcar. Outro avanço significativo se dá pela avaliação do melaço para posterior aplicação do mesmo nas plantas das usinas sucroalcooleiras como alternativa de matéria prima ou para utilização na entressafra para manutenção continua dos reatores anaeróbios usados para produção de energia limpa, renovável, de baixos custo e impacto. 
Produção de hidrogênio e metano a partir de subproduto da indústria sucroalcooleira, em reatores anaeróbios de fases separadas sob condição termofílica

38 


\section{REVISÃO BIBLIOGRÁFICA}

A revisão bibliográfica a seguir aborda o desenvolvimento do sistema de separação de fases em reatores anaeróbios, os avanços, as aplicações e estratégias adotadas, destacando as principais variáveis que influenciam o processo de produção continua e estável de bioenergia (hidrogênio e metano) relatados na literatura pertinente em seu estado da arte.

\subsection{Etapas da Digestão Anaeróbia}

O processo de digestão anaeróbia ocorre por meio de fases intimamente relacionadas. $\mathrm{Na}$ fase inicial (Hidrólise) bactérias facultativas e anaeróbias convertem matéria orgânica complexa (ex. carboidratos, lipídios, proteínas) por meio da fermentação e hidrólise biológica em compostos orgânicos mais simples (ex. açúcares, ácidos graxos, aminoácidos).

A fase acidogênica (Acidogênese) corresponde a metabolização dos produtos orgânicos solúveis provenientes da hidrólise, no interior celular das bactérias fermentativas acidogênicas, produzindo ácidos graxos voláteis (ex. acetato, butirato, propionato, lactato), gás carbônico $\left(\mathrm{CO}_{2}\right)$, hidrogênio $\left(\mathrm{H}_{2}\right)$.

A etapa acetogênica (Acetogênese) é responsável pela conversão de ácidos de cadeias mais longas a acetato $\left(\mathrm{CH}_{3} \mathrm{COO}^{-}\right)$, uma vez que em sistemas balanceados, o acetato é o principal produto da acidogênese. A Homoacetogênese é a fase em que a formação de acetato ocorre pela reação entre hidrogênio e dióxido de carbono, mediada por organismos homoacetogênicos.

Os produtos finais gerados nas fases acidogênica/acetogênica, são os substratos essenciais para a etapa final no processo global de degradação anaeróbia da matéria orgânica a Metanogênese. Na metanogênese, o metano $\left(\mathrm{CH}_{4}\right)$ e dióxido de carbono $\left(\mathrm{CO}_{2}\right)$ são produzidos pelas arquéias metanogênicas, organismos que em função da extrema afinidade pelo substrato precursor, são divididas em dois grupos principais. As arquéias metanogênicas hidrogenotróficas produzem metano a partir do $\mathrm{H}_{2}$ e do $\mathrm{CO}_{2}$, e as arquéias metanogênicas acetoclásticas produzem metano a partir do acetato.

O processo de digestão anaeróbia pode incluir ainda uma fase extra. Os despejos que contenham em sua composição química constituintes relacionados ao enxofre - $S$ - (ex. sulfato) são submetidos a fase sulfetogênica (Sulfetogênese), que é o processo ao qual os compostos a 
40

base de -S- são utilizados como aceptores de elétrons durante a oxidação dos produtos orgânicos das fases acidogênica/acetogênica produzindo sulfetos $\left(\mathrm{HS}^{+}\right.$e $\left.\mathrm{H}_{2} \mathrm{~S}\right)$.

\subsection{Melaço da Cana-de-Açúcar: Processo Produtivo, Composição e Aplicabilidade}

O melaço de cana-de-açúcar é subproduto das usinas sucroalcooleiras, resultado da etapa de centrifugação no processo de fabricação do açúcar e utilizado na fermentação para a produção de etanol (Figura 2), sendo produzido na proporção de 40 a 60 quilos por tonelada de cana-de-açúcar processada (PIACENTE, 2005).

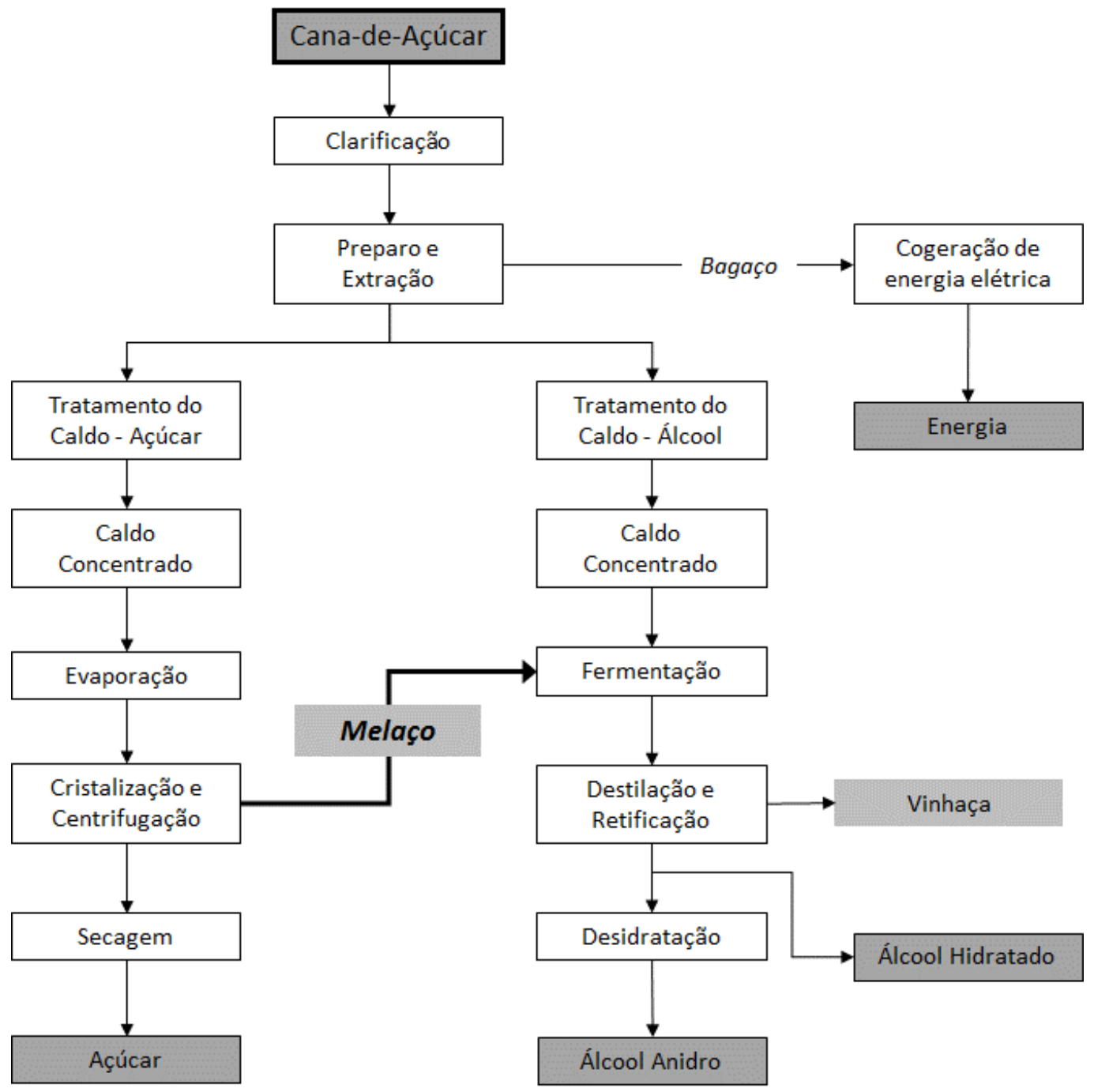

Figura 2: Fluxograma simplificado do processo produtivo de usina sucroalcooleira (Adaptado de Moraes et al., 2015). 
Rombla et al. (2009) destaca que aproximadamente $60 \%$ dos sólidos solúveis do melaço são compostos por sacarose, glicose e frutose. Os principais componentes do melaço são: a água, carboidratos, compostos não-açúcares de origem orgânica como: aminoácidos, ácidos carboxílicos alifáticos e olefínicos, vitaminas, proteínas, fenóis e outros. O melaço de cana-deaçúcar é constituído por uma fração de origem mineral de grande importância, na qual estão presentes mais de 20 metais e não-metais em diferentes proporções.

O melaço de cana-de-açúcar, possui na sua composição uma grande quantidade de açúcares fermentescíveis e é considerado um resíduo de fácil manipulação, baixo custo, com grande potencial e muitas aplicações em nível industrial (WALISZEWSKI et al., 1997).

Entretanto, a composição em relação à quantidade destes nutrientes depende de fatores agrícolas e/ou industriais, como a espécie de cana-de-açúcar cultivada, o grau de maturação, clima regional, condições de cultura, manejo de corte, eficiência industrial e processo produtivo envolvido (OLIVEIRA, 2005).

A União das Indústrias de Cana-de-Açúcar (UNICA, 2016) destaca que outra grande vantagem da aplicabilidade do melaço para o desenvolvimento de novas fontes energéticas, com pleno potencial para amplificar o desenvolvimento de diversos setores da indústria e comércio, devido a sua grande versatilidade para usos.

Diante do exposto, a utilização de subprodutos da fermentação da cana-de-açúcar pode vir a maximizar a produção de biogás em sistema anaeróbio de duas fases, pois possui potencial para produção biológica de hidrogênio e metano devido à sua concentração e conteúdo nutricional favorável ao crescimento microbiano.

Para o desenvolvimento ou crescimento de qualquer tipo de microrganismo é preciso que o substrato preencha as necessidades nutricionais do mesmo e que seja economicamente viável.

A partir desse ponto de vista, a digestão anaeróbia usando o melaço como fonte de carbono com vistas a produção de energias limpas e renováveis pode ser uma alternativa de interesse não apenas econômico, mas ambientalmente viável, uma vez que pode ser associada a outras fontes de matéria orgânica provenientes das plantas das usinas sucroalcooleiras, como a vinhaça a fim de diminuir o potencial poluidor da mesma. 


\subsection{Fatores Limitantes ao Bioprocesso da Digestão Anaeróbia em Sistema de Duas Fases}

Pohland e Ghosh (1971) relataram que o sucesso na aplicação do sistema de duas fases depende das eficiências de separação e manutenção das culturas dominantes de bactérias acidogênicas e arquéias metanogênicas nos dois reatores separados.

A separação dos microrganismos acidogênicos e os metanogênicos, no processo de digestão anaeróbia em dois estágios, poderia proporcionar melhor estabilidade para os diferentes grupos de microrganismos e melhor controle do processo (DEMIREL E YENIGUN, 2002).

Speece (1996) afirmou que a instabilidade do processo anaeróbio ocorre quando a velocidade de produção de ácidos for maior que seu consumo, acarretando queda do pH e inibição das atividades das arquéias metanogênicas, altamente sensíveis a mudanças nas condições ambientais.

Em complementação de acordo com Ueno et al. (2007) para realização de um processo eficiente de fermentação em duas fases, um desempenho compatível do reator metanogênico é necessário após a estabilização do processo acidogênico.

Entre as barreiras ao sistema de separação de fases para digestão anaeróbia de águas residuárias complexas pode-se destacar-se:

- O acúmulo de biomassa no efluente no reator acidogênico em águas residuárias ricas em carboidratos (PEIXOTO et al., 2011);

- A produção de metano com consumo do hidrogênio pelo desvio de rotas metabólicas no reator acidogênico (PENTEADO et al., 2013);

- A instabilidade e decaimento da produção de hidrogênio ao longo do tempo de operação do reator anaeróbio (FONTES LIMA e ZAIAT, 2012; PENTEADO et al., 2013);

- Os gastos extras com o tratamento prévio do inóculo para otimização dos sistemas fermentativos em condição termofílica, a fim de selecionar as bactérias formadoras de esporos, inibindo dessa maneira os organismos metanogênicos no primeiro estágio (KRAEMER e BAGLEY, 2007);

- Os custos de investimento de capital e de funcionamento de um sistema de digestão anaeróbia em dois estágios são mais elevados do que o sistema tradicional de fase única e 
aquecimento prévio dos efluentes para aplicação da tecnologia em condição termofílica é necessária (KONGJAN, et al., 2011);

- Além dos fatores limitantes relatados, outro fator de extrema importância para o sucesso da aplicação do sistema de separação de fases relatados é a necessidade de adição de solução alcalina para controlar o pH, a qual é essencial para manutenção dos organismos metanogênicos, mas apresenta um fardo econômico para o sucesso do sistema anaeróbio (KONGJAN, et al., 2013).

A partir do levantamento da problemática dos fatores limitantes do bioprocesso ao sistema anaeróbio de suas fases para a produção contínua e estável de hidrogênio no primeiro estágio e metano no segundo estágio, estratégias de controle dos reatores podem ser tomadas a fim de contornar tais problemas.

No entanto estudos aprofundados do bioprocesso de controle do sistema de duas fases ainda são necessários para sucesso da aplicação dessa tecnologia anaeróbia.

\subsection{Estratégias de Controle Operacional em Sistema de Reatores de Duas Fases}

Os reatores de leito fixo são uma boa alternativa para a produção de hidrogênio, pois apresentam configuração simples, capaz de aumentar o tempo de retenção celular, implicando em maior concentração de biomassa no reator. Além disso, não requer agitação mecânica e nem aparatos de recirculação, quando não há necessidade de diluição. Essas características resultam em redução de custos de construção e operação (LEITE et al., 2008; PERNA et al., 2013). Nessa configuração de reator, a escolha do material suporte pode ser um fator determinante na seleção da população microbiana e no custo do sistema, sendo crucial na aplicação e no desempenho do reator (SHOW et al., 2012).

A aplicabilidade da tecnologia de tratamento anaeróbio pode ser aumentada com a utilização de temperaturas elevadas nos reatores. Particularmente quando as águas residuárias são descarregadas em altas temperaturas, como por exemplo, para vinhaça e o melaço da canade-açúcar, o tratamento termofílico pode ser uma alternativa atraente (VAN LIER, 1996).

Ferraz e colaboradores (2016) afirmam que a aplicação de digestão anaeróbica termofílica é uma escolha lógica para o tratamento de subprodutos do processamento de canade-açúcar, porque esse processo permite a recuperação de energia como hidrogênio e metano sem a necessidade de aquecimento externo. Estes autores avaliaram a produção biológica de 
44

hidrogênio e metano em reatores de duas fases operados em série (acidogênico e metanogênico) e em sistema único, a partir da vinhaça da cana-de-açúcar, em condição mesofílica $\left(25^{\circ} \mathrm{C}\right)$ e termofílica $\left(55^{\circ} \mathrm{C}\right)$. Os autores utilizaram diferentes materiais suporte (argila expandida, carvão vegetal, cerâmica porosa e polietileno de baixa densidade), aplicaram aos reatores diferentes TDH e COV, (TDH de 24; 16; 12; e 8h que resultaram em COV de 36,4; 54,3; 72,4; e 108,6 kgDQO. $\mathrm{m}^{-3} \cdot \mathrm{d}^{-1}$ ) para o reator acidogênico e (TDH de 23-56h que resultaram em COV de 15 $\left.20 \mathrm{kgDQO} . \mathrm{m}^{-3} \cdot \mathrm{d}^{-1}\right)$ para o reator metanogênico. Os autores concluíram que o melhor material suporte para uso em reatores acidogênicos de leito fixo, dentre os avaliados, foi o polietileno de baixa densidade, e quanto às condições operacionais que permitiram máxima produção e rendimento de hidrogênio foram em temperatura de $55^{\circ} \mathrm{C}$; TDH de $10 \mathrm{~h}$ e $\mathrm{COV}$ de $84,2 \mathrm{~kg}$ DQO. $\mathrm{m}^{-3} \cdot \mathrm{d}^{-1}$. Em comparação aos sistemas utilizados (combinados e único) os autores relataram que a produção de energia no sistema combinado foi $25,7 \%$ superior à observada em sistema único. Estes autores ainda relatam que nas condições operacionais estudadas (material suporte, temperatura, TDH e COV) que visaram elucidar alguns fatores que influenciam a produção de hidrogênio, do ponto de vista econômico e tecnológico, a condição mesofílica é preferível comparada a termofílica. Entretanto, a condição termofílica poderia ser adotada facilmente na produção simultânea de hidrogênio e metano, que implicaria em pouca dependência de energia para o sistema, que poderia reduzir os custos da planta de tratamento. A última alternativa, segundo os autores, requer ainda maiores estudos, principalmente com respeito à estabilidade dos processos envolvidos.

Braga e colaboradores (2015) avaliaram a viabilidade da produção continua de $\mathrm{H}_{2} \mathrm{em}$ reator UASB operado sob condições termofílicas $\left(55^{\circ} \mathrm{C}\right)$ por longo período de tempo (366 dias), variando o TDH de 12 a 2 horas e usando como inóculo lodo metanogênico previamente tratado termicamente. Para alimentar o reator os autores utilizaram substrato sintético a base de sacarose. Os autores reportaram que o sistema trabalhou com o aumento de carga orgânica aplicada pela diminuição do TDH (TDH $12 \mathrm{~h}-4$ gDQO.L $\mathrm{L}^{-1} \cdot \mathrm{d}^{-1}$; TDH $8 \mathrm{~h}-6$ gDQO.L $\mathrm{L}^{-1} \cdot \mathrm{d}^{-1}$; TDH $2 \mathrm{~h}-24$ gDQO. $\left.\mathrm{L}^{-1} \cdot \mathrm{d}^{-1}\right)$ e consequentemente o decaimento do $\mathrm{pH}(7-4)$ do substrato. Os autores observaram a inibição da metanogênese no sistema após 50 dias de operação, e a produção de $\mathrm{H}_{2}$, se manteve até o final da operação do reator (366 dias). Os autores relataram que a condição termofílica imposta aliado às características do sistema estudado (baixo $\mathrm{pH}$ e aumento do TDH), foram responsáveis pela estabilização da comunidade microbiana. No entanto, os autores ainda relatam que o pré-tratamento térmico aplicado ao lodo, foi responsável pelo aumento da proporção de bactérias formadoras de esporos entre elas Clostridium spp. Os 
autores concluíram que o decaimento do THD de 12-2 horas aumentou a transferência de massa do sistema, consequentemente aumentou a porcentagem de $\mathrm{H}_{2}$ no biogás. Os autores ainda concluíram que as condições impostas de operação ao reator foi o fator mais importante para a inibição da metanogênese do que o pré-tratamento do lodo, quando observada metanogênese no início da operação $\left(\mathrm{CH}_{4}\right.$ no sistema até os 50 dias de operação).

Chen et al. (2001) avaliaram a cinética de crescimento das bactérias produtoras de hidrogênio, usando a sacarose como substrato limitante, e verificaram que baixos TDH contribuem para o arraste das arquéias metanogênicas nos sistemas de reatores de duas fases. Esse arraste ocorreu devido à velocidade especifica de crescimento das arquéias metanogênicas ser menor em relação aos organismos acidogênicos. Este arraste contribui para manutenção e crescimento dos organismos acidogênicos, inibindo dessa forma a metanogênese no primeiro reator.

Chu et al. (2008) avaliaram o desempenho operacional de um novo sistema composto para a produção de hidrogênio e metano a partir de fonte de carbono proveniente dos resíduos alimentares recolhidos no instituto nacional do meio ambiente do Japão, composto principalmente de grãos, legumes, carnes vermelhas e peixes. Os autores verificaram a viabilidade da adição de meio suporte suspenso (filtros mesófilos) no reator mesofílico para auxiliar a adesão da biomassa. O sistema usado foi composto de quatro partes, que inclui um tanque de mistura do afluente, um reator acidogênico termofílico $\left(55^{\circ} \mathrm{C}\right)$ de mistura completa (10L), seguido por reator metanogênico $\left(35^{\circ} \mathrm{C}\right)$ com filtros mesófilos como meio suporte para a biomassa (40L) e um tanque de armazenamento do lodo digerido, com parte do lodo para recirculação no reator acidogênico. O TDH utilizado para o reator acidogênico foi de 3,8 dias, o que resultou em uma taxa de carga de 64,4 kgDQO. $\mathrm{m}^{-3} \cdot \mathrm{dia}^{-1}$ e TDH para o reator metanogênico de 15,1 dias. O experimento foi conduzido por 150 dias consecutivos. Os autores citam três pontos relevantes para o sucesso das estratégias adotadas. Em primeiro lugar, a recirculação de parte do lodo armazenado no tanque para o reator acidogênico, torna o pH $(4,9)$ deste reator ideal para a produção continua de hidrogênio sem a adição de soluções estoque ou tampões. Em segundo lugar, as bactérias produtoras de hidrogênio existentes no lodo recirculado, contribuíram para manter a concentração desta comunidade no reator acidogênico. Em terceiro lugar, o meio em suspensão (filtros mesofilos) adicionado ao reator metanogênico, acelerou o crescimento de arquéias metanogênicas e tornou possível a diminuição do TDH para 5 dias. Os autores então concluíram que com os resultados obtidos com as estratégias adotadas, o processo proposto é adequado para a produção simultânea de hidrogênio e metano. 
46

A influência no tempo de detenção hidráulica, também foi avaliada por Chen e Lin (2003) que operaram um reator a processar sacarose com COA de 20 gDQO.L ${ }^{-1}$, voltado para a produção de hidrogênio, sem adaptação do inóculo e, portanto, com a presença provável de microrganismos consumidores de hidrogênio. Com a diminuição gradual do TDH de 20 dias (480h) para 2,5 dias (60h), que chegou posteriormente a $2 \mathrm{~h}$, os autores conseguiram selecionar uma cultura dominada por $C$. pasteurianum, notadamente conhecida como uma espécie produtora de hidrogênio.

Cavinato et al. (2012) otimizaram um processo anaeróbio termofílico de duas fases utilizando fonte de carbono sintética simulando esgoto sanitário, com elevado teor de sólidos, para a produção de hidrogênio e metano. Os autores usaram dois reatores com agitação (CSTR) em escala piloto. Durante o experimento, a produção de hidrogênio em baixos tempo de detenção hidráulica (3d) foi testada, com e sem recirculação de água residuária, com a aplicação de duas cargas orgânicas (16 e $21 \mathrm{~kg}$ SVT.m ${ }^{-3} \cdot \mathrm{dia}^{-1}$ ou 26,8 e 35,21 kgDQO.m ${ }^{-3} \cdot \mathrm{dia}^{-1}$ respectivamente). Os melhores rendimentos foram obtidos com recirculação, em que o pH foi mantido em 5,5, devido à capacidade de tamponamento do sistema. A produção específica de gás no primeiro reator foi de $51 \mathrm{LH}_{2} \mathrm{kgSV}^{-1}$ alimentado e teor em biogás de $37 \%$. Os autores concluíram que para o processo de digestão anaeróbia de duas fases para produção de hidrogênio e metano, que o melhor rendimento foi obtido com a menor COV (16 kg SVT.m ${ }^{-3} \cdot \mathrm{d}^{-1}$ ou 26,8 kgDQO. $\left.\mathrm{m}^{-3} \cdot \mathrm{dia}^{-1}\right)$, devido à recirculação da água residuária.

Fernandes (2008) estudou a produção biológica de hidrogênio em reatores anaeróbios de leito fixo e avaliou a influência do material suporte e do tempo de detenção hidráulico (TDH). A autora demonstrou que o material suporte (argila expandida, carvão vegetal e polietileno) não influenciou a produção biológica de hidrogênio visto que os rendimentos de hidrogênio médio foram semelhantes para todos os materiais testados, próximo a 4,4 $\mathrm{molH}_{2}$. mol $^{-1}$ sacarose para 0,5 hora e 3,3 $\mathrm{molH}_{2} \mathrm{~mol}^{-1}$ sacarose para 2,0 horas, com carga orgânica de $24 \mathrm{~kg} \cdot \mathrm{m}^{-3} \cdot \mathrm{dia}^{-1}$. A autora concluiu que o uso do TDH de 0,5 horas aumentou o rendimento de produção de hidrogênio, no entanto diminuiu a relação entre a produção volumétrica de hidrogênio obtida e a máxima teórica e a conversão de substrato.

Reis et al. (2015) avaliaram a produção de hidrogênio e metano a partir de vinhaça de cana-de-açúcar em dois reatores anaeróbios de leito fluidizado. Os reatores foram operados com diferentes concentrações de $5 \mathrm{gDQO} . \mathrm{L}^{-1}$ e $10 \mathrm{gDQOL}^{-1}$. Durante a primeira fase, a glicose era usada como a fonte primária de carbono; em seguida a vinhaça foi adicionada gradativamente em concentrações de 10 em 10\% até alcançar 100\%. Os autores usaram TDH inicial de 6h, 
diminuindo para 4, 2 e 1h. Os autores concluíram que a melhor taxa de produção de hidrogênio foi de $0,57 \mathrm{LH}_{2} \cdot \mathrm{h}^{-1}$ no reator com 5gDQO.L $\mathrm{L}^{-1}$ com TDH de 1 hora e usando vinhaça em $100 \%$. Para o rendimento de hidrogênio os autores obtiveram 3,07 $\mathrm{mmolH}_{2} . \mathrm{gDQO}^{-1}$ no mesmo reator com 5 gDQO.L ${ }^{-1}$ no entanto com TDH de 6 horas e razão vinhaça/glicose de 1:3. Pode-se concluir com os resultados obtidos por estes autores, forte influência da composição da água residuária e das cargas orgânicas aplicadas para a produção de hidrogênio e metano.

Kongjan et al. (2013) estudaram a produção de hidrogênio e metano em reatores UASB a partir do melaço de beterraba em condição termofílica $\left(55^{\circ} \mathrm{C}\right)$. Os autores aplicaram no reator acidogênico TDHs decrescentes de 16 a 3 horas o que corresponde a COV de 8,5 a 42,4 $\mathrm{gSV} \cdot \mathrm{dia}^{-1} . \mathrm{L}^{-1}$ respectivamente. O reator metanogênico foi alimentado com o efluente do reator acidogênico. Inicialmente para alcançar as cargas desejadas os autores diluíram o efluente do reator acidogênico em água e foram aplicados ao reator metanogênico TDH crescentes de 2,4 para 4 dias, conforme aumentaram o TDH diminuíram a diluição alcançando COV de 9,4 a 16,9 gSV.dia ${ }^{-1} \cdot \mathrm{L}^{-1}$. O reator acidogênico foi operado por 34 dias consecutivos e teve seu efluente homogeneizado e mantido sob temperatura de $-20^{\circ} \mathrm{C}$ para ser usado no reator metanogênico que foi operado por 150 dias consecutivos. Nessas condições, os autores alcançaram produção de hidrogênio de $5600 \mathrm{ml}$ de $\mathrm{H}_{2} \cdot \mathrm{dia}^{-1}$. $\mathrm{L}^{-1}$ e rendimento de $132 \mathrm{ml}$ de $\mathrm{H}_{2} \cdot \mathrm{gSV}^{-1}$. O efluente do reator acidogênico apresentou a melhor taxa de produção de $3380 \mathrm{ml} \mathrm{de} \mathrm{CH}_{4} \cdot \mathrm{dia}^{-1}$. $\mathrm{L}^{-1}$ e rendimento de $239 \mathrm{~mL}$ de $\mathrm{CH}_{4} \cdot \mathrm{gSV}^{-1}$.

Wang et al. (2013) analisaram o efeito do TDH na produção contínua e estável de hidrogênio em reatores CSRT, utilizando como substrato o melaço da cana-de-açúcar. O melaço utilizado continha alta concentração de carboidratos e foi diluído em água para alcançarem concentração de 8gDQO.L $\mathrm{L}^{-1}$ mantida fixa em todo o experimento. Todo o experimento ocorreu em temperatura mesofílica de $35^{\circ} \mathrm{C}$ operado por 150 dias consecutivos, com $\mathrm{pH}$ na faixa de 4,3 a 4,6. Cinco TDHs foram examinados, variando de 10 a 4h. A remoção de DQO observada ficou na faixa de 30 a 40\%, ocorrendo para manutenção celular. Durante a totalidade da operação do reator, o etanol, o ácido butírico e o ácido acético foram os metabolitos intermediários predominantes.

A Tabela 1 apresenta resumo das referências em relação as estratégias adotadas no controle operacional de reatores de duas fases. 
48

Tabela 1: Resumo das estratégias adotadas no controle operacional de reatores de duas fases

\section{Tabela Resumo com as Referências em relação as Estratégias Adotadas de Controle Operacional de Reatores de Duas Fases}

\begin{tabular}{|c|c|}
\hline Referências & Substrato / finalidade \\
\hline $\begin{array}{c}\text { Ferraz e } \\
\text { outros } 2016\end{array}$ & $\begin{array}{l}\text { Vinhaça cana-de-açúcar } \\
\text { Avaliação da produção } \\
\text { de hidrogênio e metano }\end{array}$ \\
\hline
\end{tabular}

Reatores UASB de fases Separadas

Condição mesofílica $\left(35^{\circ} \mathrm{C}\right)$ e termofílica $\left(55^{\circ} \mathrm{C}\right)$ Aplicação de diferentes TDH 24 a 8 horas e COV 36,4 a 108,6kgDQO.m ${ }^{-3} \cdot \mathrm{dia}^{-1}$

\begin{tabular}{|c|c|c|}
\hline $\begin{array}{c}\text { Braga e } \\
\text { outros } 2015\end{array}$ & $\begin{array}{l}\text { Sintético a base de } \\
\text { sacarose } \\
\text { Produção de hidrogênio }\end{array}$ & $\begin{array}{c}\text { Reatores UASB de fase única } \\
\text { Condição termofílica } \\
\text { Tratamento prévio do inóculo } \\
\text { Operado por longo período de tempo ( } 366 \text { dias) } \\
\text { Variação de TDH } 12 \text { a } 2 \text { horas } \\
\text { COV } 4 \text { a } 24 \text { gDQO.L } \text {. }^{-1} \text { dia }\end{array}$ \\
\hline $\begin{array}{l}\text { Chen et al. } \\
2011\end{array}$ & $\begin{array}{c}\text { Sacarose } \\
\text { Cinética do crescimento } \\
\text { das bactérias produtoras } \\
\text { de hidrogênio }\end{array}$ & $\begin{array}{c}\text { Reatores de duas fases } \\
\text { Baixos valores de TDH (menores que } 2 \text { horas) } \\
\text { contribuem para o arraste das arquéias } \\
\text { metanogênicas no sistema acidogênico }\end{array}$ \\
\hline $\begin{array}{l}\text { Chu et al. } \\
2008\end{array}$ & $\begin{array}{l}\text { Resíduo de alimentos } \\
\text { Produção de hidrogênio } \\
\text { e metano }\end{array}$ & $\begin{array}{c}\text { Sistema composto de reatores } \\
\text { Condição mesofílica }\left(35^{\circ} \mathrm{C}\right) \text { e termofílica }\left(55^{\circ} \mathrm{C}\right) \\
\text { Meio suporte (filtros mesofílos) aos reatores } \\
\text { mesofílicos } \\
\text { Recirculação de parte do lodo digerido ao reator } \\
\text { acidogênico }\end{array}$ \\
\hline $\begin{array}{l}\text { Chen e Li } \\
2003\end{array}$ & $\begin{array}{c}\text { Sacarose } \\
\text { Produção de hidrogênio }\end{array}$ & $\begin{array}{c}\text { Reator UASB sem adaptação do inóculo } \\
\text { COV fixa de } 20 \mathrm{gDQO} . \mathrm{L}^{-1} \\
\text { Diminuição do TDH de } 20 \text { dias para } 2,5 \text { dias }\end{array}$ \\
\hline $\begin{array}{l}\text { Cavinato et } \\
\text { al. } 2012\end{array}$ & $\begin{array}{l}\text { Sintética simulando } \\
\text { esgoto sanitário } \\
\text { Produção de hidrogênio } \\
\text { e metano }\end{array}$ & $\begin{array}{c}\text { Reatores CSTR } \\
\text { Condição termofílica }\left(55^{\circ} \mathrm{C}\right) \\
\text { TDH de } 3 \text { dias com recirculação do efluente } \\
\text { COV de } 16 \text { e } 21 \mathrm{kgSVT} . \mathrm{m}^{-3} . \text { dia }^{-1}\end{array}$ \\
\hline $\begin{array}{l}\text { Fernandes } \\
2008\end{array}$ & $\begin{array}{c}\text { Sacarose } \\
\text { Produção de hidrogênio }\end{array}$ & $\begin{array}{c}\text { Reatores anaeróbios de leito fixo } \\
\text { Diferentes materiais suporte (argila, carvão } \\
\text { vegetal e polietileno) } \\
\text { Variação de TDH ( } 2 \text { horas para } 0,5 \text { hora })\end{array}$ \\
\hline $\begin{array}{l}\text { Reis et al. } \\
\quad 2015\end{array}$ & $\begin{array}{l}\text { Vinhaça cana-de-açúcar } \\
\text { Misturada com sacarose } \\
\text { Avaliação da produção } \\
\text { de hidrogênio e metano }\end{array}$ & $\begin{array}{l}\text { Reatores anaeróbios de leito fluidizado } \\
\text { Condição mesofílica } 35^{\circ} \mathrm{C} \\
\text { CO } 5 \text { e } 10 \text { gDQO.L } \\
\text { Variação de TDH de } 6,4,2 \text { e } 1 \text { hora }\end{array}$ \\
\hline $\begin{array}{l}\text { Kongjan et } \\
\text { al. } 2015\end{array}$ & $\begin{array}{l}\text { Melaço de Beterraba } \\
\text { Produção de hidrogênio } \\
\text { e metano }\end{array}$ & $\begin{array}{l}\text { Reatores UASB de duas fases } \\
\text { Condição termofílica } 55^{\circ} \mathrm{C} \\
\text { TDH de } 16 \text { a } 3 \text { horas } \\
\text { COV de } 8,5 \text { a } 42,4 \mathrm{gSV} . \operatorname{dia}^{-1} . \mathrm{L}^{-1}\end{array}$ \\
\hline $\begin{array}{l}\text { Wang et al. } \\
2013\end{array}$ & $\begin{array}{l}\text { Melaço cana-de-açúcar } \\
\text { Produção de hidrogênio }\end{array}$ & $\begin{array}{l}\text { Reatores CSTR mesofílico }\left(35^{\circ} \mathrm{C}\right) \\
\text { TDH variando de } 10 \text { a } 4 \text { horas } \\
\text { CO fixa de } 8 \mathrm{gDQO} . \mathrm{L}^{-1}\end{array}$ \\
\hline
\end{tabular}


Diante do exposto além do entendimento dos bioprocessos aplicados, conhecer a ecologia e o papel funcional dos organismos envolvidos é crucial para a aplicabilidade da digestão anaeróbia em sistema de duas fases.

\subsection{Técnicas de Biologia Molecular para Estudo em Reatores Anaeróbios}

Em complementação as estratégias relatadas pela literatura estudos avançados de biologia molecular para estudo de reatores anaeróbios, vêm auxiliar na elucidação da ecologia dos microrganismos envolvidos e suas rotas metabólicas no bioprocesso anaeróbio.

\subsubsection{Denaturing Gradient Gel Electrophoresis (DGGE)}

A técnica molecular de DGGE, eletroforese em gel com gradiente desnaturante, proposta inicialmente por Muyzer et al. (1993), permite o estudo das comunidades microbianas e suas variações temporais influenciadas por fatores bióticos e abióticos no sistema. Permite a separação de fragmentos de DNA de cadeia dupla que são idênticos em tamanho, mas diferem na sequência.

Segundo Muyzer et al. (1993) a mistura de fragmentos de DNA de diferentes sequências é separada por eletroforese num gel de acrilamida contendo um gradiente linearmente crescente de desnaturante de DNA (normalmente ureia e formamida). Em geral, os fragmentos de DNA rico em bases GC (Guanina e Citosina) serão mais estáveis e permanecem de cadeia dupla até atingir concentrações elevadas do desnaturante. Fragmentos de DNA de cadeia dupla migram melhor no gel de acrilamida, enquanto as moléculas de DNA desnaturado tendem a parar no gel. Deste modo, os fragmentos de DNA de diferentes sequências podem ser separados num gel de acrilamida. DGGE é normalmente realizada para o gene $16 \mathrm{~S}$ do RNAr, mas podem ser utilizados também os genes funcionais. Padrões conhecidos podem ser utilizados para comparação com as amostras em diferentes géis. Teoricamente uma banda no gel corresponde a uma espécie, e, por conseguinte, o número de bandas infere sobre a diversidade da amostra. Os fragmentos de genes podem ser excisados a partir do gel, eluídos em água estéril e amplificados pela PCR. A abundância relativa de vários microrganismos pode ser estimada medindo-se a intensidade das suas bandas em relação à intensidade de todas as bandas da 
amostra correspondente. Portanto, essa técnica permite o conhecimento da variação temporal das comunidades de acordo com as condições operacionais impostas aos biorreatores (MUYZER et al., 1993).

Rodriguez et al. (2012) utilizando a técnica de DGGE e análise filogenética das bandas excisadas dos géis estudaram as relações sintróficas ente bactérias e arquéias em reator operado com vinhaça sintética e com relações de matéria orgânica e sulfato ( $\mathrm{DQO} / \mathrm{SO}_{4}{ }^{-2}$ ) de 8,4 e 2. Os autores observaram que para todas as relações $\mathrm{DQO} / \mathrm{SO}_{4}{ }^{-2}$ investigadas, as bactérias acetogênicas estavam presentes e, portanto, envolvidas na fermentação do substrato. A metanogênese ocorreu, principalmente, pelo metabolismo metilotrófico e acetoclástico das arquéias Methanomethylovorans, Methanosaeta. A metanogênese hidrogenotrófica ocorreu em baixa concentração de sulfato, relação $\mathrm{DQO} / \mathrm{SO}_{4}{ }^{-2}$ de 8 , com o predomínio de Methanobacterium. Com o aumento da concentração de sulfato, o hidrogênio foi utilizado para a redução do sulfato com detecção de Desulfovibrio $s p$.

Ferraz et al. (2014) pela técnica do DGGE e análise filogenética observaram que Clostridium beijerinckii, Clostridium butyricum, Megasphaera elsdenii e Propionispira arboris foram os organismos responsáveis pela produção de hidrogênio em reatores anaeróbios mesofílicos alimentados com glicose com diferentes cargas orgânicas.

Em outra abordagem utilizando Pirossequenciamento foi observado que organismos do gênero Megasphaera foram os que mais contribuíram para a produção de hidrogênio em reator termofílico operado com vinhaça (FERRAZ et al., 2015).

Enquanto que em condição mesofílica, Clostridium e Pectinatus foram os organismos predominantes na produção de hidrogênio (FERRAZ et al., 2015b).

\subsubsection{Sequenciamento do Metagenoma Microbiano}

A abordagem metagenômica é uma ferramenta interessante para a caracterização dos microrganismos que compõem a biomassa de reatores. A análise metagenômica permite a obtenção de milhões de sequências de DNA de uma comunidade de microrganismos, permitindo a caracterização qualitativa e quantitativa da microbiota sem a necessidade de cultivo e permite a identificação dos microrganismos pouco abundantes ou incultiváveis (SOGIN et al., 2006; ROESCH et al., 2007). 
Uma das mais recentes técnicas de sequenciamento massivo de moléculas de DNA é a plataforma Illumina MiSeq® e HiSeq2000® (Illumina Inc, USA). Esta plataforma permite a obtenção de milhões de sequências curtas de DNA ( 300 pb para MiSeq) a uma razão custo/benefício melhor quando comparado a outras plataformas similares como o 454 Pirosequenciamento® Life Sciences, USA (MARDIS, 2008).

Diversos estudos metagenômicos já foram conduzidos na análise da comunidade microbiana usando tecnologias de sequenciamento de última geração. Estas pesquisas revelaram com alta precisão a real composição da diversidade microbiana em amostras que variam do solo (ROESCH et al., 2007), ambiente marinho (MASON et al., 2014), trato gastrointestinal de humanos (QIN et al., 2010), lodo ativado (ALBERTSEN et al., 2012).

No contexto de reatores, a maioria dos trabalhos aplicaram a tecnologia 454 Pirosequenciamento® para avaliar os microrganismos envolvidos nos processos anaeróbios (WONG et al., 2013; LI et al., 2013, SUNDBERG et al., 2013, LIU et al., 2015; SAIA et al., 2015; FERRAZ et al., 2015a). Estes estudos tiveram como limitação a escala do sequenciamento, inerente da própria plataforma 454, na qual apenas algumas centenas de milhares de sequências do gene RNAr 16S foram avaliadas por amostra, limitando a avaliação mais profunda da comunidade microbiana.

Estudos mais recentes vêm aplicando a plataforma Illumina na avaliação dos microrganismos de reatores, permitindo o estudo na escala de 2,6 a 12 milhões de sequências por amostra (YANG et al., 2014; GUO et al., 2015). Apesar destes trabalhos recentes caracterizarem em detalhes a comunidade microbiana e suas funções metabólicas nos reatores anaeróbios, não há relatos do emprego da metagenômica para compreender os processos microbianos na digestão de resíduos de biorrefinárias, tais como a vinhaça e o melaço.

\subsubsection{Técnicas de PCR (Polymerase Chain Reaction) e PCR em Tempo Real (qPCR)}

Outra ferramenta biomolecular de destaque é a reação em cadeia da polimerase em tempo real ou qPCR. A técnica de qPCR tem sido considerada um importante método quantitativo de ácidos nucléicos em diferentes tipos de amostras, devido à alta sensibilidade, especificidade, reprodutibilidade e amplo desempenho de quantificação dos genes de interesse. A metodologia permite que os processos de amplificação, detecção e quantificação de DNA 
52

sejam realizados em uma única etapa, agilizando a obtenção de resultados e diminuindo o risco de contaminação da amostra e dando maior precisão (BUSTIN, 2000).

O método quantitativo de PCR em tempo real tem como base a obtenção de sinal de fluorescência durante cada amplificação de PCR comum. O fluoróforo utilizado no método pode ser sondas ligadas aos primers (ex.: sistema TaqMan) ou moléculas ligantes em fita dupla de ácido nucléico. Dentre estes, o SYBR ${ }^{\circledR}$ Green tem sido o mais intensivamente utilizado devido ao baixo custo, facilidade no desenvolvimento do ensaio, em que somente o uso de um par de primers é suficiente, além de permitir o uso de mesmo mecanismo de detecção para cada ensaio. A desvantagem se relaciona com a necessidade de primers altamente específicos, para evitar a formação de produtos secundários (ex.: dímeros de primers), que possam permitir a ligação das moléculas defluoróforo e resultar na geração de ruídos excedentes de fluorescência na PCR (SHIPLEY, 2006).

O método quantitativo por qPCR possui grande potencial para aplicações analíticas e análise de transcritomas, no entanto, diversas fontes de ruídos devem ser controladas, dentre as quais podem ser citadas: a qualidade e armazenagem do material vivo e RNA isolado; a quantidade inicial de RNA; a especificidade dos primers na reação; a eficiência enzimática; a diferenças entre a atividade transcricional dos tecidos e das células; o delineamento do ensaio em cada corrida de qPCR no equipamento; e por fim a definição dos valores de eficiência de cada curva de amplificação. Além disso, deve haver preocupação com a necessidade na normalização dos dados brutos obtidos com o uso de normalizadores internos adequados para cada condição avaliada (BUSTIN et al., 2009).

$\mathrm{Na}$ análise dos níveis de transcritos (RNAm) de uma determina amostra por qPCR em tempo real deve ser realizada uma etapa inicial, onde ocorre a síntese de cDNA a partir da ação da enzima transcritase reversa (RT). Esta atua sobre as moléculas de RNAm da amostra, que caracteriza assim a técnica por qPCR em tempo real. Em seguida, o PCR quantitativo segue com a amplificação da sequência alvo em quatro fases: 1) linha de base; 2) exponencial; 3) linear; 4) platô. Na linha de base a amplificação ocorre de forma indetectável pelo equipamento. Por outro lado, a fase exponencial compreende a detecção precoce de sinais de fluorescência durante reação da PCR onde a amplificação ocorre até a taxa exponencial máxima, que resulta na determinação do threshold e, consequente, valor de Cq (ciclo de quantificação). Neste caso, em uma reação ideal, duas moléculas completas são sintetizadas de cada fita molde disponível na fase exponencial em que resulta na máxima eficiência (SHIPLEY, 2006). 
No contexto da utilização de técnicas biomoleculares aplicadas a amostras ambientais, Terry Brown (2012), avaliou o efeito do acréscimo gradativo da carga orgânica volumétrica aplicada, em reator anaeróbio de biomassa imobilizada, a partir da vinhaça da cana-de-açúcar, e então acompanhou as alterações na diversidade microbiana frente ao desempenho do reator anaeróbio. Para quantificar as populações microbianas (domínio Bacteria, domínio Archea e Bactérias Redutoras de Sulfato - BRS), a autora empregou a técnica de qPCR, para amostras ambientais. Com os dados obtidos a autora concluiu que a técnica da reação em cadeia da polimerase em tempo real (qPCR), aplicada ao estudo da microbiota de reatores biológicos, mostrou-se eficiente na diferenciação quantitativa dos principais organismos, e revelou que do total da população microbiana, as arquéias representaram a população quantitativamente superior com mais de $90 \%$ e que a população menos abundante foi representada pelas BRS.

\subsection{Considerações Finais}

Associada à estabilidade do processo, a velocidade de digestão anaeróbia é maior em condição termofílica em relação a mesofílica, além disso, a operação na faixa termofílica pode ser amplamente utilizada em indústrias em que a água residuária já está nessa condição de temperatura, fato que pode diminuir custos nas plantas de produção de biogás das indústrias sucroalcooleiras, em que tanto o melaço quanto a vinhaça já se encontram em condição termofílica, não necessitando de aparatos para a alteração da temperatura.

A partir do levantamento da problemática dos fatores limitantes do sistema ao bioprocesso nos sistemas de reatores de duas fases, estratégias podem ser adotadas a fim de contornar tais problemas. As barreiras apresentadas podem ser contornadas com determinadas estratégias para a manutenção de um sistema de duas fases com sucesso de aplicação, com produção continua e estável de hidrogênio em primeiro estágio, seguido da produção de metano em segundo estágio, com redução do potencial poluidor da água residuária, com ganho energético, econômico e ambiental.

Para isso é apresentado na Tabela 2 resumo das estratégias e hipóteses adotadas para este estudo, para manutenção estável do sistema de duas fases com vistas à recuperação continua e estável de hidrogênio por longo período de tempo, seguido da produção de metano em reatores anaeróbios de leito fixo estruturado e fluxo ascendente. 
Tabela 2: Estratégias e hipóteses adotadas para este estudo, para manutenção estável do sistema de duas fases

\begin{tabular}{cc}
$\begin{array}{c}\text { Características dos Sistemas } \\
\text { Anaeróbios }\end{array}$ & $\begin{array}{c}\text { Possíveis Estratégias Adotadas para } \\
\text { Contornar os Problemas }\end{array}$ \\
\hline
\end{tabular}

Possibilidade de uso de TDHs Baixos em

Tempo de crescimento celular

acelerado no sistema acidogênico reatores acidogênicos, favorecendo organismos

com metabolismo acelerado, tais como as

bactérias acidogênicas no primeiro estágio.

A pressão de $\mathrm{H}_{2}$ no reator acidogênico permite

Necessidade de controle da pressão de a sua recuperação, concomitantemente à a hidrogênio produção de ácidos encaminhada ao reator metanogênico para a produção de $\mathrm{CH}_{4}$.

Manutenção da produção de metano Favorecimento pela produção de ácidos orgânicos voláteis (acetato) no primeiro reator.

Geração de lodo devido ao rápido crescimento dos organismos acidogênicos Redução da geração de lodo em reatores com biomassa imobilizada.

Utilização de águas residuárias com baixos valores de $\mathrm{pH}$ diretamente no reator acidogênico 
3 OBJETIVOS

\subsection{Objetivo Geral}

O objetivo geral do presente trabalho foi produzir hidrogênio e metano em sistema de reatores anaeróbios de separação de fases, acidogênica e metanogênica (parcialmente, para a última) respectivamente, a partir de subproduto da indústria sucroalcooleira (melaço da canade-açúcar).

\subsection{Objetivos Específicos}

- Estudar as condições para estabelecimento da fermentação ácida do melaço em condições termofílicas, contemplando: - a escolha de inóculo; - a seleção de população acidogênica por carga elevada e temperatura de $55^{\circ} \mathrm{C}$;

- Verificar o desempenho e a longevidade do processo, indispensáveis para proposição de tecnologia de geração de gás combustível, nos reatores acidogênicos com diferentes inóculos;

- Relacionar o processo de digestão ácida com os microrganismos envolvidos, utilizando técnicas modernas de biologia molecular no estado da arte como o Sequenciamento Metagenômico, qPCR, PCR-DGGE;

- Estabelecer a digestão anaeróbia do efluente do reator acidogênico para o reator metanogênico, vislumbrando a redução da concentração de álcali adicionado para a redução dos custos associados para geração de metano, a partir de ácidos orgânicos produzidos na fase anterior;

- Verificar o potencial de produção de energia a partir do hidrogênio e metano gerados, por massa de melaço utilizada. 
Produção de hidrogênio e metano a partir de subproduto da indústria sucroalcooleira, em reatores anaeróbios de fases separadas sob condição termofílica 


\section{INSTALAÇÕES, TÉCNICAS EXPERIMENTAIS E MÉTODOS ANALÍTICOS}

\subsection{Estrutura do Experimento}

Os experimentos foram conduzidos em reatores anaeróbios de leito fixo estruturado com fluxo ascendente. A fonte de carbono utilizada para alimentação foi uma diluição do melaço in natura, coletado na Usina São Martinho em Pradópolis (SP). A diluição, com água de abastecimento, foi feita para que a fonte de carbono apresentasse a DQO desejada. Os reatores foram abastecidos por meio de bombas peristálticas (Gilson ${ }^{\circledR}$ Inc.). Todo o experimento foi realizado em câmara térmica sob condição termofílica de $55^{\circ} \mathrm{C}$.

Na etapa 1, dois reatores acidogênicos foram operados em paralelo, a carga orgânica volumétrica aplicada (COV) de ambos foi incrementada pelo aumento de concentração de DQO do afluente, com TDH constante de 2 h. Na etapa seguinte (Etapa 2), um reator acidogênico e outro reator metanogênico foram operados em série. $O$ reator acidogênico foi alimentado com melaço diluído em água e o TDH e COV mantidos constante. O reator metanogênico foi alimentado com efluente do reator acidogênico e a COV foi alterada pelo aumento de vazão e consequente diminuição do TDH.

A primeira etapa do trabalho consistiu na utilização de dois reatores acidogênicos. Foram usadas diferentes formas de inoculação e meios suportes; as cargas orgânicas volumétricas aplicadas (COV) foram incrementadas pelo aumento da concentração DQO afluente com TDH fixo de 2 horas (Tabela 3). A escolha das COV e do TDH fixo se deu principalmente por resultados positivos na produção continua de $\mathrm{H}_{2}$ relatados por Braga et al. (2015).

Tabela 3: Condições operacionais dos reatores acidogênicos - Etapa 1

\begin{tabular}{|c|c|c|c|c|c|}
\hline \multicolumn{6}{|c|}{ Procedimentos operacionais dos Reatores Acidogênicos } \\
\hline Identificação & Inóculo & Meio Suporte & $\begin{array}{l}\text { DQO } \\
(\text { g.L.-1) }\end{array}$ & $\begin{array}{c}\text { TDH } \\
\text { (Horas) }\end{array}$ & $\begin{array}{c}\text { COV } \\
\left(\text { gDQO}^{\prime} \mathbf{L r}^{-1} \cdot \mathrm{dia}^{-1}\right)\end{array}$ \\
\hline Reator 1 & $\begin{array}{c}\text { Vinhaça } \\
\text { autofermentada }\end{array}$ & $\begin{array}{l}\text { Polietileno de } \\
\text { baixa densidade }\end{array}$ & $2,5,5$ e 10 & 2 & 30,60 e 120 \\
\hline Reator 2 & $\begin{array}{c}\text { Lodo de reator } \\
\text { UASB }\end{array}$ & $\begin{array}{l}\text { Espuma de } \\
\text { Poliuretano }\end{array}$ & $2,5,5$ e 10 & 2 & 30,60 e 120 \\
\hline
\end{tabular}


Assim optou-se por uma das duas configurações apresentadas para continuar o trabalho na próxima etapa, ou seja, associar o reator acidogênico ao reator metanogênico.

Após a conclusão da Etapa 1, partiu-se para a segunda etapa do estudo que consistiu em manter o reator (Acidogênico) na condição de $10 \mathrm{gDQO} . \mathrm{L}^{-1}$ correspondente a COV de 120 gDQO.Lreator ${ }^{-1} \cdot$ dia $^{-1}$, sob TDH de 2 horas, em que foi observada maior geração de ácidos orgânicos de interesse e melhor produção continua de hidrogênio.

Na etapa 2 foi acoplado ao sistema acidogênico, um reator metanogênico em condição termofílica $\left(55^{\circ} \mathrm{C}\right)$, alimentado com o efluente proveniente do primeiro reator. Obtendo assim um sistema composto de dois reatores anaeróbios em série com separação de fases (Reator Acidogênico e sequencialmente Reator Metanogênico).

O Reator metanogênico foi operado com cargas orgânicas volumétricas aplicadas $(\mathrm{COVm})$ crescentes, por meio do aumento da vazão e consequente diminuição do TDH.

Assim foram avaliadas 7 fases distintas (I-VII) com aumento da COVm (gDQO.Lreator ${ }^{-1} \cdot \mathrm{dia}^{-1}$ ), de acordo com os procedimentos operacionais apresentados na Tabela 4: Condições operacionais impostas ao reator metanogênico, em que pode-se observar as oscilações de DQO afluente (gDQO.L $\left.{ }^{-1}\right)$ e as variações de TDH (horas).

Tabela 4: Condições operacionais impostas ao reator metanogênico

\begin{tabular}{ccccccccc}
\hline \multicolumn{7}{c}{ Procedimentos Operacionais do Reator Metanogênico } \\
\cline { 2 - 9 } Variáveis & I & II & III & IV & V & VI & VII \\
\hline $\begin{array}{c}\text { Carga Orgânica Efluente } \\
\text { Reator Acidogênico } \\
\left.\text { (gDQO.L }{ }^{-1}\right)\end{array}$ & 9 & 9 & 9 & 9 & 14 & 17 & 11 \\
\hline TDH (horas) & 240 & 96 & 48 & 32 & 24 & 16 & 12 \\
\hline $\begin{array}{c}\text { Carga Orgânica Volumétrica } \\
\text { Aplicada (COVm) } \\
\left(\text { gDQO.Lreator } \text { (dia }^{-1} \text { ) }\right.\end{array}$ & 1,00 & 2,00 & 5,00 & 7,00 & 14,00 & 26,00 & 17,50 \\
\hline
\end{tabular}

Para melhor compreensão do trabalho é apresentado na Figura 3, o fluxograma de configuração do experimento, suas etapas e fases aplicadas. 


\section{FLUXOGRAMADE CONFIGURAÇÃODO EXPERIMENTO}

\section{ETAPA 1 \\ SISTEMA PARALELO \\ ACIDOGÊNICO}

Reator Acidogênico R1

Fonte de Carbono: Melaço da cana-de-açúcar Inoculação: Vinhaça Autofermentada

Meio Suporte: Polietileno de Baixa Densidade

DQO: $2,5,5$ e $10 \mathrm{gDQO} . \mathrm{L}^{-1}$

COV: 30,60 e 120 gDQO.Lreator ${ }^{-1} \cdot$ dia $^{-1}$

TDH Aplicado: 2 horas

Condição Termofilica $55^{\circ} \mathrm{C}$

\section{Reator Acidogênico R2}

Fonte de Carbono: Melaço da cana-de-açúcar Inoculação: Lodo de Reator UASB

Meio Suporte: Espuma de Poliuretano

DQO: $2,5,5$ e 10 gDQO.L ${ }^{-1}$

COV: 30,60 e 120 gDQO.Lreator ${ }^{-1}$. dia ${ }^{-1}$

TDH Aplicado: 2 horas

Condição Termofilica $55^{\circ} \mathrm{C}$
Identificação de Melhor Desempenho do Reator Acidogênico

\section{Reator Acidogênico}

Fonte de Carbono: Melaço da cana-de-açúcar

Inoculação: Lodo de Reator UASB

Meio Suporte: Espuma de Poliuretano

DQO: $10 \mathrm{gDQO} . \mathrm{L}^{-1}$

COV: 120 gDQO.Lreator ${ }^{-1} \cdot$ dia $^{-1}$

TDH Aplicado: 2 horas

Condição Termofílica $55^{\circ} \mathrm{C}$

\section{Afluente Reator Metanogênico}

SISTEMA COMBINADO

ACIDOGÊNICO - METANOGÊNICO

Figura 3: Fluxograma de configuração do experimento.

\subsubsection{Reatores Anaeróbios}

Os reatores anaeróbios de leito fixo estruturado com fluxo ascendente foram confeccionados em acrílico, com volume aproximado de 1,65 L. Os reatores contam com 5 pontos de amostragem ao longo de sua altura, além de orifício para amostragem de biogás. Aos reatores foram acoplados selos hídricos e medidores de volume de biogás (Figura 4 a e b). 
60

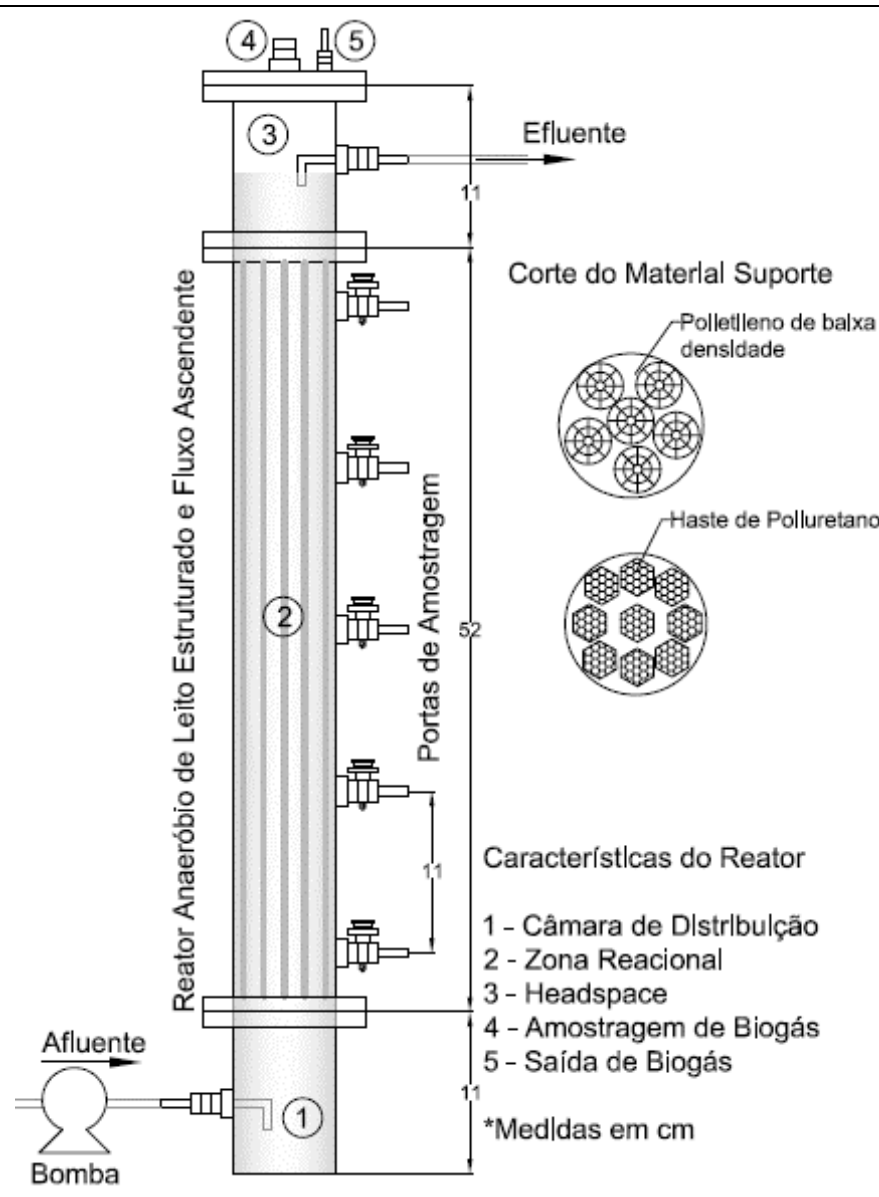

a)

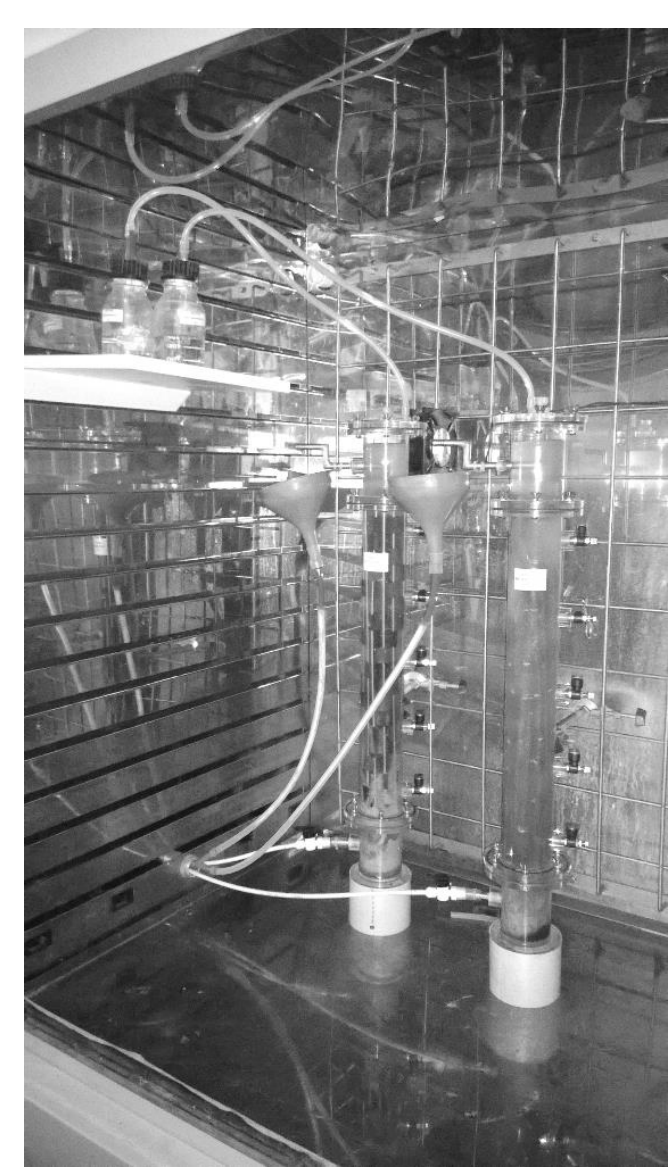

b)

Figura 4: Layout estrutural do experimento; a) Layout reator anaeróbio de leito fixo estruturado, b) Estrutura e esquema experimental dos reatores na câmara termofílica $\left(55^{\circ} \mathrm{C}\right)$.

\subsubsection{Materiais Suporte dos Reatores Acidogênicos}

Para imobilização da biomassa foram escolhidos 2 tipos distintos de materiais suportes: espuma de poliuretano e polietileno de baixa densidade. Ambos os materiais apresentaram bom desempenho na produção de hidrogênio e metano de acordo com Peixoto (2011), Ferraz (2013) e Anzolas-Rojas (2014).

O leito estruturado do reator acidogênico (R1) foi constituído de polietileno de baixa densidade (Figura 5a), disposto em 5 peças cilíndricas intercaladas, de $4 \mathrm{~cm}$ de comprimento por 1,3 cm de raio, em 13 fileiras dentro do reator totalizando 65 peças (Tabela 5).

O leito estruturado do reator acidogênico (R2) foi constituído de 9 hastes prismáticas de espuma de poliuretano (Figura 5b), cada haste tem $60 \mathrm{~cm}$ de comprimento por $1 \mathrm{~cm}$ de aresta Tabela 5. 
61

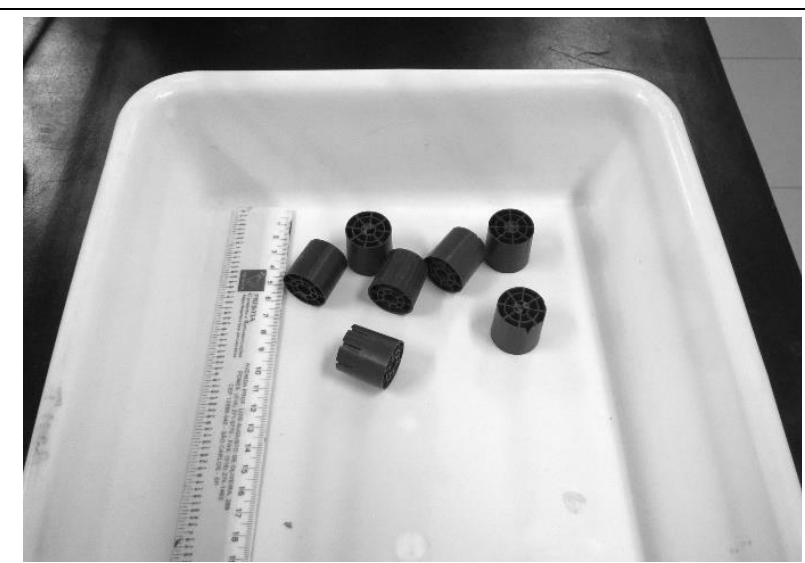

a)

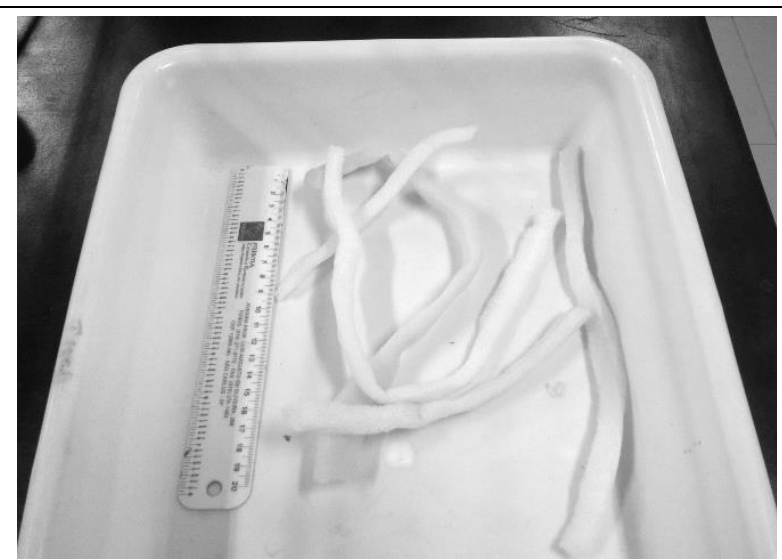

b)

Figura 5: Materiais suporte utilizados a) Polietileno de baixa densidade; b) Hastes de espuma de poliuretano.

Tabela 5: Características dos materiais suportes utilizados

\begin{tabular}{ccccc}
\hline \multicolumn{4}{c}{ Características dos Materiais Utilizados Como Meios Suportes } \\
\hline Material & Disposição & Comprimento & Largura & Porosidade \\
\hline $\begin{array}{c}\text { Polietileno de } \\
\text { Baixa Densidade }\end{array}$ & $\begin{array}{c}5 \text { peças cilíndricas } \\
\text { intercaladas por } \\
\text { hastes }\end{array}$ & $\begin{array}{c}4 \mathrm{~cm} \mathrm{de} \\
\text { comprimento }\end{array}$ & $1,3 \mathrm{~cm}$ de raio & Não se aplica* \\
\hline $\begin{array}{c}\text { Espuma de } \\
\text { Poliuretano }\end{array}$ & $\begin{array}{c}9 \text { hastes } \\
\text { prismáticas }\end{array}$ & $\begin{array}{c}60 \mathrm{~cm} \mathrm{de} \\
\text { comprimento }\end{array}$ & $1 \mathrm{~cm}$ de aresta & $73 \% \%^{* *}$ \\
\hline
\end{tabular}

* Ferraz (2013)

** Peixoto (2011)

\subsubsection{Material Suporte Reator Metanogênico}

O leito estruturado do reator metanogênico foi constituído de 9 hastes prismáticas de espuma de poliuretano, cada haste tem $60 \mathrm{~cm}$ de comprimento, $1 \mathrm{~cm}$ de aresta e porosidade do leito de $73 \%$, conforme descrito para o reator acidogênico (R2). A escolha deste material para compor a configuração do reator metanogênico, se deu devido a resultados positivos na melhora da produção de metano, descritos conforme estudo de Silva et al. (2011).

\subsubsection{Monitoramento da Operação dos Reatores}

Para etapa 1, os reatores acidogênicos foram operados em paralelo por aproximadamente 45 dias. Após este período foi realizado o tratamento dos dados obtidos e 
62

identificado o reator de melhor eficiência, quanto a produção continua de hidrogênio e geração de ácidos orgânicos de interesse para a metanogênese.

O reator de melhor desempenho na acidogênese foi mantido, com produção continua de hidrogênio por longo período de tempo, fechando ciclo total com 417 dias de operação.

O reator metanogênico foi operado por 251 dias consecutivos com produção contínua de metano, sendo alimentado com o efluente acidificado do reator acidogênico descrito anteriormente.

\subsection{Procedimentos Experimentais}

\subsubsection{Inoculação dos Reatores}

\subsubsection{Reatores Acidogênicos}

A inoculação dos reatores acidogênicos se deu por meio de dois procedimentos distintos, em um foi realizada a auto fermentação da vinhaça da usina São Martinho, e em outro foi inoculado por meio de grânulos obtidos no efluente de reator anaeróbio de fluxo ascendente e manta de lodo (UASB), tratando vinhaça.

O primeiro procedimento se deu por autofermentação da vinhaça $(10 \mathrm{~L})$, oriunda da Usina São Martinho. A vinhaça foi previamente filtrada em papel qualitativo (Nalgon, $80 \mathrm{~g} \cdot \mathrm{m}^{-2}$, porosidade $3 \mu \mathrm{m}$ ) a fim de diminuir a interferência dos sólidos em suspensão. $\mathrm{O}$ pH da vinhaça foi ajustado para 6,5, por adição de hidróxido de sódio a $50 \%\left(\mathrm{~m} . \mathrm{v}^{-1}\right)$ e mantido em repouso durante três dias em câmara escura. Após o período de repouso, o efluente fermentado foi bombeado para R1 e recirculado por um período de 5 dias, de acordo com Leite et al. (2008).

O procedimento de inoculação do reator R2 se deu pela utilização de lodo granulado proveniente de reator UASB tratando vinhaça da cana-de-açúcar $(500 \mathrm{ml})$, na própria Usina São Martinho. A escolha se justifica devido principalmente condição termofílica imposta no sistema de tratamento. Seguindo as recomendações de Godoi et al. (2015) o lodo foi submetido à trituração mecânica para desfazer os grânulos em porções menores, misturado e homogeneizado no meio suporte, deixados em repouso por 24 horas a temperatura ambiente. Após este processo o material foi transferido para o reator. 


\subsubsection{Reator Metanogênico}

A inoculação do reator metanogênico, para a Etapa 2 do trabalho, se deu pela utilização lodo granulado proveniente de reator UASB em condições mesofílicas $\left(35^{\circ} \mathrm{C}\right)$, tratando água residuária de abatedouro de aves $(500 \mathrm{ml})$. A escolha se justifica devido principalmente à grande diversidade microbiana apresentada no lodo (SILVA, 2006). O lodo foi submetido à trituração mecânica para desfazer os grânulos em porções menores seguindo recomendações de Godoi et al. (2015), misturado e homogeneizado no meio suporte, deixados em repouso por 24 horas a temperatura ambiente. Após este processo o material foi transferido para o reator metanogênico, em condição termofílica $\left(55^{\circ} \mathrm{C}\right)$.

\subsubsection{Matriz Orgânica Utilizada no Experimento}

A matriz orgânica utilizada para este experimento foi o melaço in natura da cana-deaçúcar, coletado na Usina São Martinho, em Pradópolis/SP.

A utilização de uma fonte de carbono com características constantes possibilita maior controle dos processos estudados, para obtenção de conhecimentos fundamentais. Para isso o melaço foi armazenado durante todo o período de operação a $4^{\circ} \mathrm{C}$, para evitar alterações em sua característica inicial. Por ser um subproduto da indústria sucroalcooleira, a avaliação da produção de biogás a partir dessa matriz pode representar ganho energético adicional expressivo.

O melaço da cana-de-açúcar é um composto de consistência pastosa, por isso optou-se por diluir em água, assim os resultados das análises são expressos em massa (gramas) por litro da diluição.

A caracterização prévia do melaço foi realizada para verificar a sua composição e atingir os valores de DQO afluente estipulados nas etapas experimentais (Tabela 3).

Foram pesadas previamente $10 \mathrm{~g}$ de melaço e diluídas em 1 litro de água destilada para a caracterização físico-química, conforme Tabela 6. 
64

Tabela 6: Caracterização do melaço e da vinhaça de cana-de-açúcar

\begin{tabular}{|c|c|c|}
\hline \multicolumn{3}{|c|}{ Caracterização do melaço e da vinhaça de cana-de-açúcar } \\
\hline \multirow{2}{*}{ Parâmetros } & \multirow{2}{*}{ Unidades } & Melaço diluído* \\
\hline & & Valores \\
\hline $\mathrm{pH}$ & Adimensional & 4,78 \\
\hline DQO Total & $\left(\mathrm{mg} . \mathrm{L}^{-1}\right)$ & 8.720 \\
\hline DQO solúvel $(0.45 \mu \mathrm{m})$ & $\left(\mathrm{mg} \cdot \mathrm{L}^{-1}\right)$ & 7.880 \\
\hline $\mathrm{DBO}_{5}$ & $\left(\mathrm{mg} . \mathrm{L}^{-1}\right)$ & 3.992 \\
\hline Alcalinidade Total & $\left(\mathrm{mg} \mathrm{CaCO}{ }_{3} \cdot \mathrm{L}^{-1}\right)$ & 37 \\
\hline N. Amoniacal & $\left(\mathrm{mg} \mathrm{N} . \mathrm{L}^{-1}\right)$ & 67 \\
\hline N.T.K & $\left(\mathrm{mg} \mathrm{N} . \mathrm{L}^{-1}\right)$ & 269 \\
\hline Nitrato & $\left(\mathrm{mg} \mathrm{N}-\mathrm{NO}_{3}^{-} \cdot \mathrm{L}^{-1}\right)$ & 295 \\
\hline Nitrito & $\left(\mathrm{mg} \mathrm{N}-\mathrm{NO}_{2}^{-} \cdot \mathrm{L}^{-1}\right)$ & 0,10 \\
\hline Sulfato & $\left(\mathrm{mg} \mathrm{SO}_{4}{ }^{2-} \cdot \mathrm{L}^{-1}\right)$ & 70 \\
\hline Sulfeto & $\left(\mathrm{mg} \mathrm{S} 2_{2}^{-} \cdot \mathrm{L}^{-1}\right)$ & 0,190 \\
\hline \multirow{2}{*}{ Fenol } & $\left(\mathrm{mg} \mathrm{C}_{6} \mathrm{H}_{5} \mathrm{OH} . \mathrm{L}^{-1}\right)$ & 0,082 \\
\hline & Série Metais & \\
\hline Zinco & $\left(\mathrm{mg} \mathrm{Zn} . \mathrm{L}^{-1}\right)$ & 0,168 \\
\hline Chumbo & $\left(\mathrm{mg} \mathrm{Pb} . \mathrm{L}^{-1}\right)$ & 0,06 \\
\hline Cádmio & $\left(\mathrm{mg} \mathrm{Cd} . \mathrm{L}^{-1}\right)$ & 0,055 \\
\hline Níquel & $\left(\mathrm{mg} \mathrm{Ni} . \mathrm{L}^{-1}\right)$ & 0,576 \\
\hline Ferro & $\left(\mathrm{mg} \mathrm{Fe} . \mathrm{L}^{-1}\right)$ & 0,838 \\
\hline Manganês & $\left(\mathrm{mg} \mathrm{Mn} \cdot \mathrm{L}^{-1}\right)$ & 0,270 \\
\hline Cobre & $\left(\mathrm{mg} \mathrm{Cu} . \mathrm{L}^{-1}\right)$ & 0,053 \\
\hline Cromo Total & $\left(\mathrm{mg} \mathrm{Cr} . \mathrm{L}^{-1}\right)$ & 0,044 \\
\hline Cálcio & $\left(\mathrm{mg} \mathrm{Ca} . \mathrm{L}^{-1}\right)$ & 287,00 \\
\hline Magnésio & $\left(\mathrm{mg} \mathrm{Mg} \cdot \mathrm{L}^{-1}\right)$ & 21,18 \\
\hline Sódio & $\left(\mathrm{mg} \mathrm{Na} \cdot \mathrm{L}^{-1}\right)$ & 4,70 \\
\hline \multirow[t]{2}{*}{ Potássio } & $\left(\mathrm{mg} \mathrm{K} . \mathrm{L}^{-1}\right)$ & 216 \\
\hline & Carboidratos & \\
\hline Glicose & $\left(\mathrm{mg} . \mathrm{L}^{-1}\right)$ & $2.443,30$ \\
\hline Frutose & $\left(\mathrm{mg} . \mathrm{L}^{-1}\right)$ & 845,50 \\
\hline Metanol & $\left(\mathrm{mg} \cdot \mathrm{L}^{-1}\right)$ & N/D \\
\hline \multirow[t]{2}{*}{ Etanol } & $\left(\mathrm{mg} \cdot \mathrm{L}^{-1}\right)$ & N/D \\
\hline & s Orgânicos Volát & \\
\hline Cítrico & $\left(\mathrm{mg} . \mathrm{L}^{-1}\right)$ & $1.584,05$ \\
\hline Málico & $\left(\mathrm{mg} . \mathrm{L}^{-1}\right)$ & 312,90 \\
\hline Lático & $\left(\mathrm{mg} \cdot \mathrm{L}^{-1}\right)$ & N/D \\
\hline Fórmico & $\left(\mathrm{mg} \cdot \mathrm{L}^{-1}\right)$ & N/D \\
\hline Succínico & $\left(\mathrm{mg} \cdot \mathrm{L}^{-1}\right)$ & N/D \\
\hline Acético & $\left(\mathrm{mg} \cdot \mathrm{L}^{-1}\right)$ & N/D \\
\hline Propiônico & $\left(\mathrm{mg} \cdot \mathrm{L}^{-1}\right)$ & N/D \\
\hline Butírico & $\left(\mathrm{mg} \cdot \mathrm{L}^{-1}\right)$ & $\mathrm{N} / \mathrm{D}$ \\
\hline Valérico & $\left(\mathrm{mg} \cdot \mathrm{L}^{-1}\right)$ & 175,45 \\
\hline Capróico & $\left(\mathrm{mg} \cdot \mathrm{L}^{-1}\right)$ & N/D \\
\hline
\end{tabular}

Continua... 


\begin{tabular}{|c|c|c|}
\hline \multirow{2}{*}{ Parâmetros } & \multirow{2}{*}{ Unidades } & Melaço* \\
\hline & & Valores \\
\hline & Série de Sólidos & \\
\hline Sólidos Totais & $\left(m g . L^{-1}\right)$ & 7.651 \\
\hline Sólidos Totais Fixos & $\left(\mathrm{mg} . \mathrm{L}^{-1}\right)$ & 521 \\
\hline Sólidos Totais Voláteis & $\left(\mathrm{mg} \cdot \mathrm{L}^{-1}\right)$ & 7.130 \\
\hline Sólidos Suspensos Totais & $\left(\mathrm{mg} \cdot \mathrm{L}^{-1}\right)$ & 197 \\
\hline Sólidos Suspensos Fixos & $\left(\mathrm{mg} \cdot \mathrm{L}^{-1}\right)$ & 27 \\
\hline Sólidos Suspensos Voláteis & $\left(\mathrm{mg} \cdot \mathrm{L}^{-1}\right)$ & 170 \\
\hline Sólidos Dissolvidos Totais & $\left(\mathrm{mg} \cdot \mathrm{L}^{-1}\right)$ & 7.454 \\
\hline Sólidos Dissolvidos Fixos & $\left(\mathrm{mg} \cdot \mathrm{L}^{-1}\right)$ & 494 \\
\hline Sólidos Dissolvidos Voláteis & $\left(\mathrm{mg} . \mathrm{L}^{-1}\right)$ & 6.960 \\
\hline
\end{tabular}

* Diluição de melaço em água 10g.L ${ }^{-1}$

N/D não detectável

\subsubsection{Controle do $\mathrm{pH}$}

\subsubsection{Reatores Acidogênicos}

Para os reatores acidogênicos ao longo do experimento não foi realizado qualquer controle do $\mathrm{pH}$ afluente, obtendo $\mathrm{pH}$ médio entorno de 5,5 $\pm 0,2$, para ambos, pois compartilhavam da mesma fonte de carbono.

\subsubsection{Reator Metanogênico}

Para o reator metanogênico, ao longo do experimento, foi realizado o controle do $\mathrm{pH}$ com bicarbonato de sódio $\left(\mathrm{NaHCO}_{3}\right)$. Sendo que para cada grama de DQO aplicada por litro de substrato foi adicionado inicialmente, 1,2 gramas de $\mathrm{NaHCO}_{3}$ (P.A.) como solução tampão. No entanto a adição foi regredindo com o passar das fases em menos de 0,2 gramas de $\mathrm{NaHCO}_{3}$ por fase, de acordo com a tabela a seguir: 
66

Tabela 7: Controle do $\mathrm{pH}$ para as fases metanogênicas

\begin{tabular}{|c|c|c|c|c|c|c|c|}
\hline \multicolumn{8}{|c|}{ Controle do pH para as Fases Metanogênicas } \\
\hline \multirow{2}{*}{ Variáveis } & \multicolumn{7}{|c|}{ Fases Avaliadas na Metanogênese } \\
\hline & I & II & III & IV & $\mathbf{V}$ & VI & VII \\
\hline $\begin{array}{c}\text { Carga Orgânica Efluente } \\
\text { Reator Acidogênico } \\
\left(\mathrm{gDQO}^{-1}\right)\end{array}$ & 9 & 9 & 9 & 9 & 14 & 17 & 11 \\
\hline $\begin{array}{c}\mathrm{NaHCO}_{3} \\
\left(\mathrm{gNaHCO}_{3}\right) \cdot\left(\mathrm{gDQO}^{-1}\right)^{-1}\end{array}$ & 1,20 & 1,00 & 0,80 & 0,60 & 0,40 & 0,20 & 0,20 \\
\hline
\end{tabular}

\subsection{Metodologia Analítica}

\subsubsection{Produção de Biogás}

O volume de gás produzido foi mensurado com auxílio do medidor de volume de gás Milligas Counter da Ritter®. Foi realizado fator de correção em função da temperatura de operação do reator. Dado pela Equação 1.

$$
T=\frac{P \times K}{R \times(273+T)}
$$

Em que: p é a pressão atmosférica igual a $1 \mathrm{~atm}, K$ é correspondente a $1 \mathrm{~mol}$ do biogás obtido, $R$ é a constante universal dos gases e $T$ é a temperatura de operação do reator em $55^{\circ} \mathrm{C}$.

\subsubsection{Composição do Biogás}

A análise da composição do biogás gerado - dióxido de carbono $\left(\mathrm{CO}_{2}\right)$, metano $\left(\mathrm{CH}_{4}\right)$ e hidrogênio $\left(\mathrm{H}_{2}\right)$ foi realizada em cromatógrafo gasoso Shimadzu GC-2010, equipado com uma coluna capilar Carboxen 1010 PLOT (30mm x 0,32mm) e detector de condutividade térmica. A temperatura do injetor, do detector foi mantida em $220^{\circ} \mathrm{C}$ e rampa de aquecimento da coluna foi de $130^{\circ} \mathrm{C}$ a $135^{\circ} \mathrm{C}$, a $46^{\circ} \mathrm{C} \cdot \mathrm{min}^{-1}$. A vazão do gás de arraste (Argônio) utilizado foi de 5,66 mL.min ${ }^{-1}$ e o volume de amostra injetado foi de $500 \mu \mathrm{L}$. 


\subsubsection{Determinação da Demanda Química de Oxigênio}

A análise da Demanda Química de Oxigênio (DQO) foi realizada pela metodologia descrita no Standard Methods for the Examination of Water and Wastewater (APHA, 2012).

\subsubsection{Determinação do Potencial Hidrogeniônico}

$\mathrm{O}$ pH foi mensurado em pHmetro de bancada seguindo recomendações de Standard Methods for the Examination of Water and Wastewater (APHA, 2012).

\subsubsection{Determinação da Alcalinidade}

A alcalinidade foi realizada de acordo com a metodologia descrita em Dilallo e Albertson (1961), modificado por Ripley et al. (1986), que por titulação alcalimétrica mensura a alcalinidade total, parcial, intermediária e a bicarbonato (AT, AP, AI e AB). De posse dos resultados o monitoramento foi realizado pela razão da Alcalinidade Intermediária pela Alcalinidade Parcial (relação AI/AP).

\subsubsection{Determinação da Concentração de Carboidratos Totais}

A concentração dos carboidratos totais foi determinada pelo método fenol-sulfúrico proposto por Dubois et al. (1956). Após desidratação do açúcar pelo ácido sulfúrico e complexação dos produtos formados com o fenol, a absorbância da solução foi medida na região visível (490 nm) em espectrofotômetro e substituída na equação gerada a partir da curva padrão de sacarose $\left(1 \% \mathrm{~m} \cdot \mathrm{v}^{-1}\right)$ de intervalo de 20 a $600 \mathrm{mgC}{ }_{12} \mathrm{H}_{22} \mathrm{O}_{11} \cdot \mathrm{L}^{-1}$.

\subsubsection{Determinação de Ácidos Totais}

A concentração dos ácidos totais foi determinada pelo método da titulação acidimétrica proposto por Dilallo e Albertson (1961) que recomenda a fervura da amostra acidificadada por 3 minutos para remoção de $\mathrm{CO}_{2}$. 
68

\subsubsection{Caracterização dos Ácidos Orgânicos Voláteis}

Os ácidos orgânicos voláteis (cítrico, málico, succínico, lático, fórmico, acético, propiônico, butírico e capróico) foram determinados por cromatografia líquida de alta eficiência (HPLC). Analisados por sistema Shimadzu® equipado com bomba LC-10ADVP, válvula FCV10ALVP, detector ultravioleta (UV) com arranjo de diodos (SPD-M10 AVP), controlador SCL10AVP e injetor Rheodyne ${ }^{\circledR}\left(100 \mu \mathrm{L}\right.$ loop), com coluna Aminex ${ }^{\circledR} \mathrm{HPX}-87 \mathrm{H}$ (300mm x 7,8mm; Bio58 Rad). Os resultados das injeções cromatográficas foram analisados com auxílio do software Class-VP Shimadzu®. A elaboração das curvas de calibração do HPLC seguiu as recomendações do fabricante do equipamento e a preparação das amostras seguiu metodologia descrita em Lazaro (2009).

\subsection{Análises Biomoleculares}

\subsubsection{Amostragem da Biomassa para Análises Biomoleculares}

Amostras da biomassa foram coletadas para as análises moleculares nas zonas reacionais dos reatores anaeróbios de leito estruturado acidogênicos.

As amostras foram coletadas em R1 e em R2 no início e fim de cada fase operacional (COV de 30, 60 e 120gDQO.Lreator ${ }^{-1} \cdot \operatorname{dia}^{-1}$ ).

A estrutura da comunidade microbiana foi verificada pela técnica do DGGE em cada fase frente às variações de carga orgânica volumétrica aplicadas aos reatores.

A amplificação dos genes das bactérias e arquéias metanogênicas foi feita técnica da Reação em Cadeia da Polimerase (PCR).

A quantificação das bactérias e arquéias metanogênicas foi realizada pela técnica de PCR em tempo real (qPCR).

O Sequenciamento Metagenômico foi aplicado à caracterização da microbiota associada aos reatores anaeróbios acidogênicos também no final de cada fase operacional. 


\subsubsection{Extração do DNA Total}

A extração do DNA total para a DGGE foi realizada por meio da lise mecânica com pérolas de vidro, seguido da recuperação e purificação do DNA com fenol-clorofórmio, conforme o procedimento de Griffiths et al. (2000). Para as análises de qPCR e metagenômica, a extração de DNA foi feita utilizando o PowerSoil@ DNA Isolation Kit Mobio, seguindo as instruções do fabricante. A qualidade do DNA foi aferida por eletroforese em gel de agarose $(1,2 \%)$ em tampão Tris-Acetato-EDTA $1 X$ (Tris 1x - 4,84 g Tris, $1,14 \mathrm{ml}$ ácido acético e 0,74g EDTA para $1 \mathrm{~L}$ de $\mathrm{dH}_{2} \mathrm{O}$ ) corado com Blue Green Loading Dye I. O padrão de bandas utilizados foi o low DNA mass ladder - Invitrogen®. Se necessário, uma segunda purificação do DNA foi realizada por meio do kit de purificação (Illustra CFX PCR DNA e Gel Band PurificationGE Healthcare), de acordo com as instruções do fabricante a fim de eliminar ou reduzir possíveis interferentes para realizar a polimerase reaction chain (PCR).

\subsubsection{DGGE (Denaturing Gradient Gel Electrophoresis)}

Os genes 16S rRNA foram amplificados pela reação da cadeia em polimerase (PCR) usando os primers para o Domínio Bacteria (968FGC - 1401R) e Archaea (1400R-1100FG), conforme os procedimentos descritos em Nubel et al. (1996) e Kudo et al. (2006), respectivamente e adicionados deGC-clamp (MUYZER E SMALLA, 1998). Alíquotas de $1 \mu 1$ de DNA foram adicionadas a mistura de reação seguindo os procedimentos descritos no manual de instruções da Taq polymerase (Promega- Brazil). As reações de PCR foram conduzidas em equipamento termociclador GeneAmp PCR System 2400 (PERKIN-ELMER, NORWALK, CONN., USA).

DGGE foi feito em DCodeTM Universal Mutation Detection System (Bio-Rad Laboratories). Os produtos da PCR foram aplicados em gel de poliacrilamida 8\% (wt/v) em tampão TAE $(0.5 \times)$ com gradiente de desnaturação de $30-70 \%$ de uréia e formamida. A eletroforese prosseguiu a $75 \mathrm{~V}, 400 \mathrm{~mA}, 60 \mathrm{~W}$ e temperatura de $65^{\circ} \mathrm{C}$ por 16 horas. Os géis foram corados com solução de brometo de etídeo (1 $1 \mu \mathrm{lml}-1)$, visualizados sob luz UV e fotografados em equipamento Eagle Eye II (modelo Stratagene) com Eaglesight-Stratagene (v3.22) software. 
A análise do padrão de bandas dos géis de DGGE foi realizada com o software BioNumerics versão 2.5.

Para a comparação entre os diferentes perfis de bandas foram construídos Dendrogramas, para os domínios encontrados e analisados pela porcentagem do índice de similaridade de Jaccard (GOODALL, 1966), que considera a presença e ausência de bandas.

\subsubsection{Amplificação dos Genes por PCR (Polimerase Reaction Chain)}

A Polimerase Reaction Chain (PCR) ou Reação em Cadeia da Polimerase possibilita a síntese de fragmentos de DNA, pela enzima DNA-polimerase, a mesma que participa da replicação do material genético nas células. Esta enzima sintetiza uma sequência complementar de DNA, desde que um pequeno fragmento (primer) já esteja ligado a uma das cadeias do DNA no ponto escolhido para o início da síntese. Os iniciadores definem a sequência a ser replicada e o resultado obtido é a amplificação de uma determinada sequência DNA com bilhões de cópias (HIRASAWA, 2007).

\subsubsection{Quantificação dos Genes por PCR em Tempo Real (qPCR)}

A PCR em tempo real realiza a quantificação dos ácidos nucléicos de maneira precisa e com maior reprodutibilidade, porque determina valores durante a fase exponencial da reação. O ponto que detecta o ciclo na qual a reação atinge o limiar da fase exponencial é denominado de Cycle Threshold (CT). Este ponto permite a quantificação exata e reprodutível baseado na fluorescência.

A fim de quantificar o número de genes envolvidos, será gerada uma curva padrão através da representação gráfica do Crossing-treshold (CT) em função do logaritmo da concentração dos produtos de PCR purificados, obtidos por amplificação do gene RNAr 16S a partir do DNA genômico de uma cultura pura de bactéria.

Os genes para o Domínio Bacteria e Archaea foram amplificados por pesquisadores da Universidade de Wageningen (WUR) - Holanda, segundo os procedimentos adotados pela WUR. Os genes da Fe-hidrogenase foram amplificados em colaboração com o Departamento de Ciência do Solo da Escola Superior de Agricultura "Luiz de Queiroz" (ESALQ/USP), com os primers e procedimentos descritos em Fang et al. (2006). 


\subsubsection{Sequenciamento Metagenômico}

O Sequenciamento Metagenômico foi aplicado à caracterização da microbiota associada aos reatores anaeróbios acidogênicos, para compreender os processos microbianos na digestão de resíduos de biorrefinárias.

Para o reator acidogênico (USBR1), as amostras foram analisadas para o inóculo, e para cada COV de 30gDQO. $\operatorname{Lr}^{-1} \cdot \operatorname{dia}^{-1} ; 60$ gDQO.Lr ${ }^{-1} \cdot \mathrm{dia}^{-1}$ e $120 \mathrm{gDQO} \cdot \mathrm{Lr}^{-1} \cdot \mathrm{dia}^{-1}$.

Para o reator acidogênico (USBR2), as amostras foram analisadas para o inóculo, e para cada COV de 30 gDQO. $\operatorname{Lr}^{-1} \cdot \operatorname{dia}^{-1} ; 60$ gDQO. $\operatorname{Lr}^{-1} \cdot \mathrm{dia}^{-1}$ e $120 \mathrm{gDQO} \cdot \mathrm{Lr}^{-1} \cdot \mathrm{dia}^{-1}$.

Após a coleta o DNA foi extraído das amostras e submetido ao processo de sequenciamento metagenômico em sistema MiSeq ${ }^{\circledR}$ da Ilumina realizado pelo Centro de Genômica Funcional da ESALQ/USP e seguindo os procedimentos deste Centro.

As sequencias resultantes de sequenciamento por metagenômica plataforma MiSeq ${ }^{\circledR}$ passaram por uma análise de qualidade na qual foram removidas sequencias com Phred score abaixo de 30, foi permitido um máximo de 6 homopolímeros, não foi tolerado nenhuma base ambígua ("N") na sequência, e todas as sequencias abaixo de 300 pb foram descartadas, seguindo os protocolos descritos pelo fabricante do equipamento (MiSeq® ILUMINA, 2016). As análises de bioinformática foram feitas em colaboração com a Universidade Federal de Santa Catarina (UFSC).

\subsection{Análises Estatísticas e Matemáticas}

\subsubsection{Análises Estatísticas dos Dados Obtidos}

Os dados estatísticos foram avaliados conforme descritos em Morettin e Bussab (2011), usados os testes de Coeficiente de Correlação, Variação Conjunta, Ajustes de Curva Polinomial e Boxplot. Os dados foram trabalhados estatisticamente pelo software Microsoft Office Excel® 2016, habilitado com os complementos estatísticos de Data Analysis e Solver. Adotou-se para todos os testes estatísticos aplicados um nível de significância de 5\%, conforme proposto em Dagnelie (1973). 


\subsubsection{Análises Matemáticas do Desempenho dos Reatores}

Com os resultados obtidos nas análises previamente descritas utilizou-se o software Microsoft Office Excel® 2016, para realizar os cálculos das equações de valores máximos, médio e desvio padrão do desempenho geral do reator, produção de hidrogênio, produção de metano e balanços de massa e energético.

\section{$\underline{\text { Vazão aplicada }}$}

$$
Q=\frac{V u}{T D H}
$$

Em que: Vu é o volume útil, ou seja, é o volume reacional do reator (1,65L); TDH é o tempo de detenção hidráulico aplicado.

\section{Carga orgânica volumétrica}

$$
\operatorname{COV}=\frac{D Q O \text { Afluente } \times Q}{V u}
$$

Em que: DQO Afluente é a concentração de matéria orgânica afluente no reator; Q é a vazão definida.

\section{Eficiência de conversão de DQO}

$$
D Q O=\frac{(\text { DQOaf }- \text { DQOef })}{\text { DQOaf }} \times 100 \%
$$

Equação 4

Em que DQOaf é a concentração de matéria orgânica afluente e DQOef é a concentração de matéria orgânica no efluente.

\section{$\underline{\text { Eficiência de conversão de carboidrato (sacarose) }}$}

$$
C S=\frac{(C S a f-C S e f)}{C S a f} \times 100 \%
$$

Em que CSaf é a concentração de carboidrato afluente e CSef é a concentração de carboidrato no efluente. 
$\underline{\text { Velocidade de conversão de carboidrato (sacarose) }}$

$$
V c s=\frac{Q \times(C S a f-C S e f)}{M M s c}
$$

Equação 6

Em que MMsc é a massa molar da sacarose $\left(\sim 342,30\right.$ g.mol $\left.{ }^{-1}\right)$.

\section{$\underline{\text { Vazão de biogás produzido no reator }}$}

$$
Q_{b}=\frac{V m}{T}
$$

Em que: Vm é o volume obtido no medidor e T é o tempo de intervalo de cada medida.

\section{$\underline{\text { Cálculo de } n\left(\mathrm{~g} \cdot \mathrm{mol}^{-1}\right)}$}

$$
n=\frac{P \times V i}{R \times T}
$$

Em que: $P$ é a pressão de gás em atm, $V i$ o volume de gás injetado, $R$ a constante universal dos gases ideais e $T$ a temperatura absoluta. Nesse trabalho a pressão foi de $1 \mathrm{~atm}$ e a temperatura de $55^{\circ} \mathrm{C}$ (temperatura absoluta $=298 \mathrm{~K}$ ).

\section{Porcentagem de distribuição dos gases}

Hidrogênio $\left(\% \mathrm{H}_{2}\right)$ :

$\% H_{2}=\frac{n H_{2}}{n}$

Equação 9

Metano $\left(\% \mathrm{CH}_{4}\right)$ :

$\% \mathrm{CH}_{4}=\frac{n C H_{4}}{n}$

Equação 10

Dióxido de Carbono $\left(\% \mathrm{CO}_{2}\right)$ :

$\% \mathrm{CO}_{2}=\frac{n C O_{2}}{n}$

Em que: $\mathrm{nH}_{2}, \mathrm{nCH}_{4}, \mathrm{nCO}_{2}$, são os números de mols de cada gás contido no biogás; $n$ corresponde ao número de mols totais na amostra injetada. Esse conteúdo foi medido por cromatografia e calculado pelas curvas de calibração do cromatógrafo. O valor de $n$ corresponde ao número de mols totais na amostra de gás injetado, calculado usando a equação dos gases ideais. 
$\underline{\text { Vazões molares dos gases }}$

Vazão molar de hidrogênio $\left(\mathrm{VMH}_{2}\right)$

$V M H_{2}=Q b \times \frac{n H_{2}}{V i}$

Equação 12

Vazão molar de metano $\left(\mathrm{VMCH}_{4}\right)$

$\mathrm{VMCH}_{4}=Q b \times \frac{n C H_{4}}{V i}$

Em que: $n \mathrm{H}_{2}$ e $n \mathrm{CH}_{4}$, correspondem ao número de mols de cada gás contido no biogás; Vi representa o volume de biogás injetado no cromatógrafo; $Q b$ é a vazão do biogás no reator.

\section{Produções bruta dos gases}

Produção bruta de hidrogênio $\left(\mathrm{PBH}_{2}\right)$

$\mathrm{PBH}_{2}=\mathrm{Qb} \times \% \mathrm{H}_{2}$

Equação 14

Produção bruta de metano $\left(\mathrm{PBCH}_{4}\right)$

$\mathrm{PBCH}_{4}=\mathrm{Qb} \times \% \mathrm{CH}_{4}$

Equação 15

Em que: Qb é a vazão do biogás no reator; $\% \mathrm{H}_{2}$ e $\% \mathrm{CH}_{4}$ são as porcentagens de distribuição dos gases; Vútil é o volume útil reacional do reator.

\section{Produções volumétricas dos gases (CNTP)}

Produção volumétrica de hidrogênio $\left(\mathrm{PVH}_{2}\right)$

$\mathrm{PVH}_{2}=\frac{Q_{b} \times \% \mathrm{H}_{2}}{V \text { útil }}$

Produção volumétrica de metano $\left(\mathrm{PVCH}_{4}\right)$

$\mathrm{PVCH}_{4}=\frac{Q_{b} \times \% \mathrm{CH}_{4}}{V \text { útil }}$

Em que: Qb é a vazão do biogás no reator; $\% \mathrm{H}_{2}$ e $\% \mathrm{CH}_{4}$ são as porcentagens de distribuição dos gases; Vútil é o volume útil reacional do reator.

C: $273,15^{\circ} \mathrm{K}\left(0^{\circ} \mathrm{C}\right)$ e $\mathrm{T}: 101325 \mathrm{~Pa}(760 \mathrm{mmHg})$

\section{$\underline{\text { Rendimentos de hidrogênio }}$}

Rendimento de hidrogênio por mol de $\mathrm{H}_{2}$ por mol de carboidrato convertido $\left(\mathrm{YH}_{2}\right)$

$Y H_{2}=\frac{V M H_{2}}{V C S}$

Equação 18

Em que: Qb é a vazão do biogás; e Vcs é a velocidade de conversão de carboidrato. 
Rendimento de hidrogênio pela produção bruta de $\mathrm{H}_{2}$ por litro de melaço diluído $\left(\mathrm{YPBH}_{2}\right)$ $Y P B H_{2}=\frac{P B H_{2}}{Q}$

Equação 19

Rendimento de hidrogênio pela produção volumétrica $\mathrm{H}_{2}$ por de melaço diluído $\left(\mathrm{YPVH}_{2}\right)$ $Y P V H_{2}=\frac{P V H_{2}}{Q}$

Em que: Q é a vazão no reator e melaço diluído gmelaço.L $\mathrm{L}^{-1}(11,44 \mathrm{~g}$ melaço em 1 litro de água).

Rendimento de hidrogênio pela produção bruta de $\mathrm{H}_{2}$ por massa de melaço $\left(\mathrm{ZPBH}_{2}\right)$ $Z P B H_{2}=\frac{P B H_{2}}{Q m}$ Equação 21

Em que: Qm é a massa ( $\mathrm{kg}$ ) de melaço aplicado por litro.

\section{$\underline{\text { Rendimentos de metano }}$}

Rendimento de metano pela produção bruta de $\mathrm{CH}_{4}$ pela DQO removida $\left(\mathrm{YCH}_{4}\right)$ $Y_{C H}=\frac{Q_{b} \times \% C H_{4}}{Q \times\left(D Q O_{a f}-D Q O_{e f}\right)}$

Equação 22

Em que: Qb é a vazão do biogás no reator; Q é a vazão no reator; DQOaf é a DQO afluente; DQOef é a DQO efluente.

Rendimento de metano pela produção bruta de $\mathrm{CH}_{4}$ por melaço diluído $\left(\mathrm{YPBCH}_{4}\right)$ $Y \mathrm{PBCH}_{4}=\frac{\mathrm{PBCH}_{4}}{Q}$ Equação 23

Rendimento de metano pela produção volumétrica $\mathrm{CH}_{4}$ por melaço diluído $\left(\mathrm{YPVCH}_{4}\right)$ $\mathrm{YPVCH}_{4}=\frac{\mathrm{PVCH}_{4}}{Q}$ Equação 24

Em que: Q é a vazão no reator, melaço diluído (11,44g melaço em 1 litro de água).

Rendimento de metano $\left(\mathrm{ZPBCH}_{4}\right)$ pela produção bruta de $\mathrm{CH}_{4}$ por massa $(\mathrm{Kg})$ de melaço $\mathrm{ZPBCH}_{4}=\frac{\mathrm{PBCH}_{4}}{Q m}$

Em que: Qm é a massa $(\mathrm{kg})$ de melaço aplicado por litro. 
76

$\underline{\text { Rendimentos energéticos de hidrogênio e metano }}$

Cálculo do rendimento energético de hidrogênio $\left(\mathrm{JH}_{2}\right)$

$\mathrm{JH}_{2}=m l H_{2} \times 12,9$

Equação 26

O rendimento energético de hidrogênio foi calculado de acordo com o proposto por

Kongjan et al. (2013), em que a cada $\mathrm{ml} \mathrm{de} \mathrm{H}_{2}$ produzido corresponde a 12,9 Joules (J).

Cálculo do rendimento energético de metano $\left(\mathrm{JCH}_{4}\right)$

$\mathrm{JCH}_{4}=\mathrm{mlCH}_{4} \times 40,1$

Equação 27

$\mathrm{O}$ rendimento energético de metano foi calculado de acordo com o proposto por

Kongjan et al. (2013), em que a cada $\mathrm{ml}$ de $\mathrm{CH}_{4}$ produzido corresponde a 40,1 Joules (J).

\section{Conversão dos rendimentos energéticos para Wattshora}

Podemos obter os valores dos rendimentos energéticos de hidrogênio e metano $\left(\mathrm{JH}_{2} \mathrm{e}\right.$ $\mathrm{JCH}_{4}$ ) em Wattshora (Wh) usando o fator de conversão de 2,77×10-4 de acordo com a Equação 28.

$W P B=J \times 2,77 \times 10^{-4}$

Equação 28 
5 APRESENTAÇÃO E DISCUSSÃO DOS RESULTADOS

\subsection{Etapa 1 - Análise e Comparação dos Reatores Acidogênicos}

Neste item são abordados os dados referentes a operação dos reatores acidogênicos em paralelo, alimentados com melaço, usando distintos meios suportes e inóculos de diferentes procedências.

\subsubsection{Análise Comparativa do Desempenho dos Reatores Acidogênicos}

Esta primeira etapa compreendeu o início da operação dos reatores acidogênicos, afim de comparar os diferentes inóculos e meios suportes favoráveis a acidogênese, relatados na literatura, polietileno de baixa densidade segundo Peixoto (2011) e espuma de poliuretano segundo Ferraz (2013).

Os reatores foram submetidos às mesmas condições operacionais de temperatura $\left(55^{\circ} \mathrm{C}\right)$ e THD de 2 horas; operados em paralelo durante 45 dias, divididos da seguinte forma, 1 aos 12 (DQO de 2,5 g.L $\mathrm{L}^{-1}$ ); 13 aos 26 (DQO de 5 g.L $\mathrm{L}^{-1}$ ); 27 aos 45 dias (DQO de 10 g.L $\mathrm{L}^{-1}$ ), o que corresponde a Cargas Orgânicas Volumétricas (COVs) de 30, 60 e 120 gDQO.Lreator ${ }^{-1}$.dia ${ }^{-1}$ respectivamente (Figura 6).

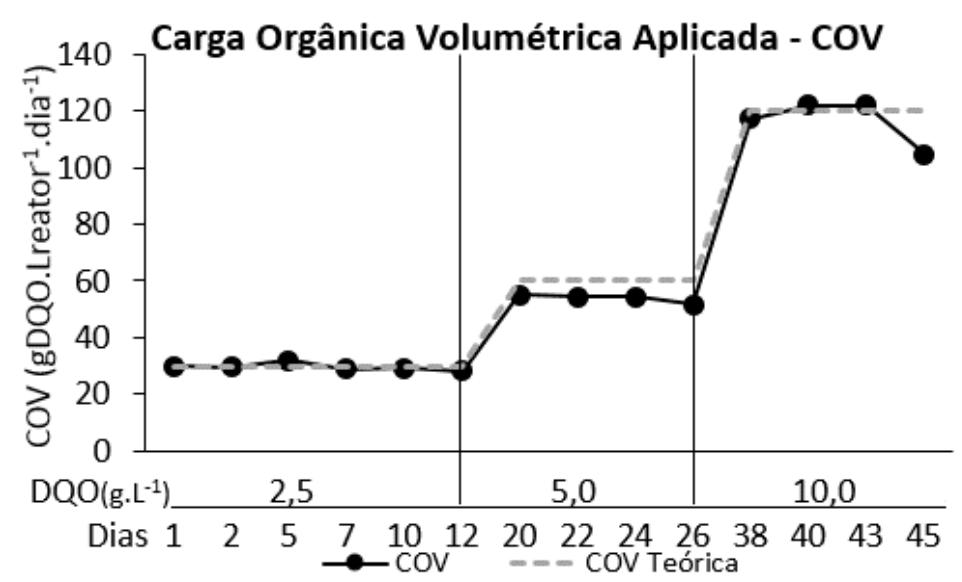

Figura 6: Monitoramento temporal da Carga Orgânica Volumétrica Aplicada (COV). 
$\mathrm{O}$ afluente dos reatores acidogênicos não foi suplementado com álcali e o $\mathrm{pH}$ ficou em

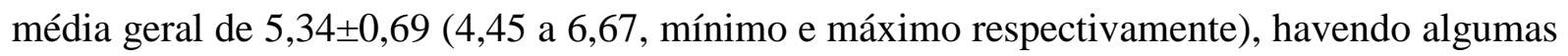
oscilações ocasionadas devido a renovação do substrato. No efluente, o pH manteve praticamente estável para ambos os reatores e em todas as cargas aplicadas, com variação pouco maior em R1, sendo que média geral para R1 ficou em 4,11 $\pm 0,23(3,80$ a 4,65) e em R2 4,12 $\pm 0,19$ (3,86 a 4,57). Os resultados indicam a ocorrência de acidogênese em ambos os reatores (Figura 7a).

A análise estatística de boxplot do efluente de ácidos totais corroboram com a premissa da acidificação de ambos os reatores, nota-se no gráfico da (Figura 7b) que houve aumento da concentração de ácidos totais, tanto em R1 quanto em R2.

Para o Reator R1 a média geral de ácidos totais ficou em $249 \pm 91 \mathrm{mg} . \mathrm{L}^{-1}$ (101 a 383 mg. $\mathrm{L}^{-1}$ ) e a carga de ácidos de média de $2985 \pm 1090 \mathrm{mg} . \mathrm{L}^{-1} \cdot \mathrm{dia}^{-1}$, enquanto que para ao reator R2 a média geral de ácidos totais ficou em $303 \pm 98$ mg.L $\mathrm{L}^{-1}\left(127\right.$ a $479 \mathrm{mg} . \mathrm{L}^{-1}$ ) valores mínimos e máximos respectivamente e a carga de ácidos de $3640 \pm 1190 \mathrm{mg} \cdot \mathrm{L}^{-1} \cdot \mathrm{dia}^{-1}$.

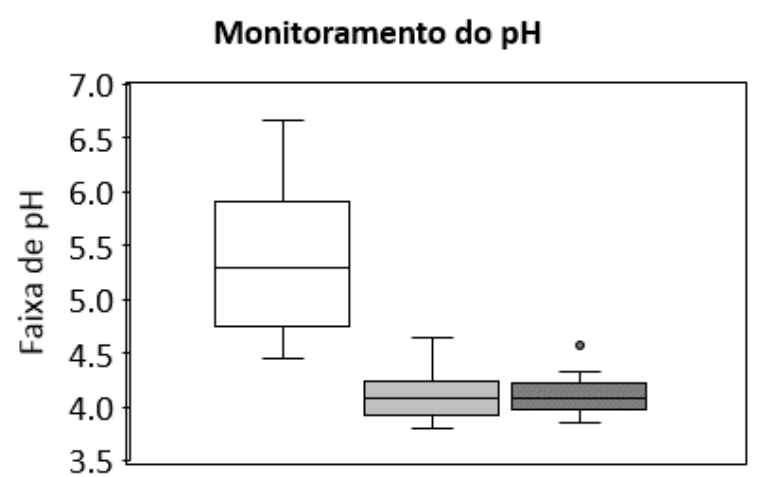

a)

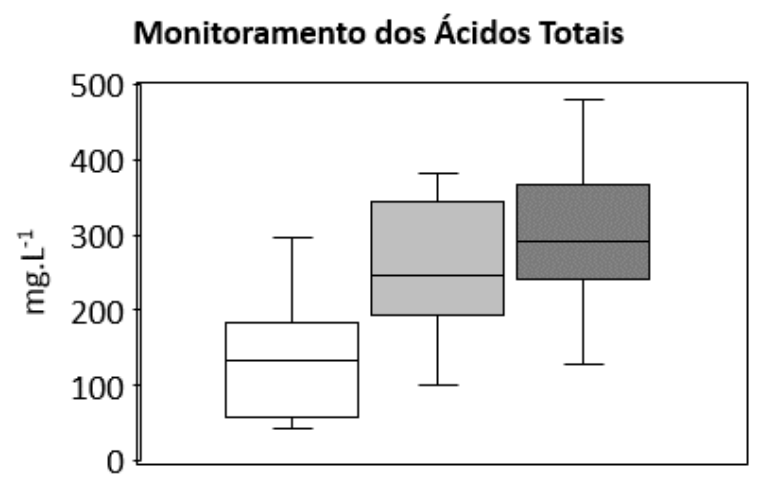

b) $\square$ Afluente $\square$ Reator R1 $\square$ Reator R2

Monitoramento da Carga de Ácidos Totais

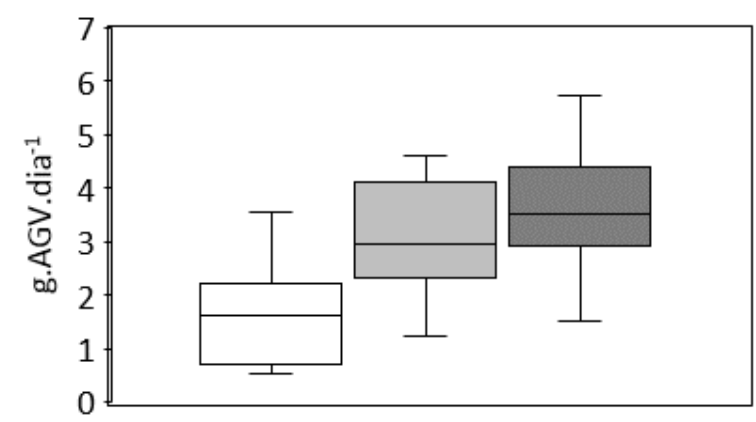

c) $\square$ Afluente $\square$ Reator R1 $\square$ Reator R2

Figura 7: Monitoramento dos reatores acidogênicos - Etapa 1; a) Análise estatística de boxplot do monitoramento do $\mathrm{pH}$, b) Análise estatística de boxplot monitoramento da geração de ácidos totais, c) Análise estatística de boxplot monitoramento da carga de ácidos totais. 
A remoção de matéria orgânica (DQO) é muito baixa no processo acidogênico (valores de 5\% até 30\% relatados na literatura pertinente) tanto para a DQO Bruta (Figura 8a), quanto para a DQO Solúvel (Figura 8b). Visto que os dados para ambas (DQO) foram bem próximos, optou-se por relacionar com os resultados obtidos apenas a DQO bruta.

Foi observado para ambos os reatores as maiores porcentagens de remoção de matéria orgânica no início da operação (COV inicial de 30 gDQO.Lreator ${ }^{-1} \cdot$ dia $^{-1}$ ). Em que o reator R1 apresentou média de porcentagem de eficiência de remoção de 16,48\% e o reator R2 média de eficiência de 23,65\%, decaindo ao longo da mesma etapa. A partir do incremento de COV, foi observado a redução da remoção de DQO atingindo médias de 6,98 e 3,36\% em R1 e 11,89 e 4,05\% para R2, nas COVs de 60 e 120 gDQO.Lreator ${ }^{-1}$.dia ${ }^{-1}$, respectivamente (Figura 8a).

Os valores de remoção de DQO mais elevados no início da operação do que nas fases subsequentes, podem estar associados a maiores necessidades metabólicas para o crescimento e geração celular dos reatores nas fases iniciais (Anzola-Rojas, 2014).

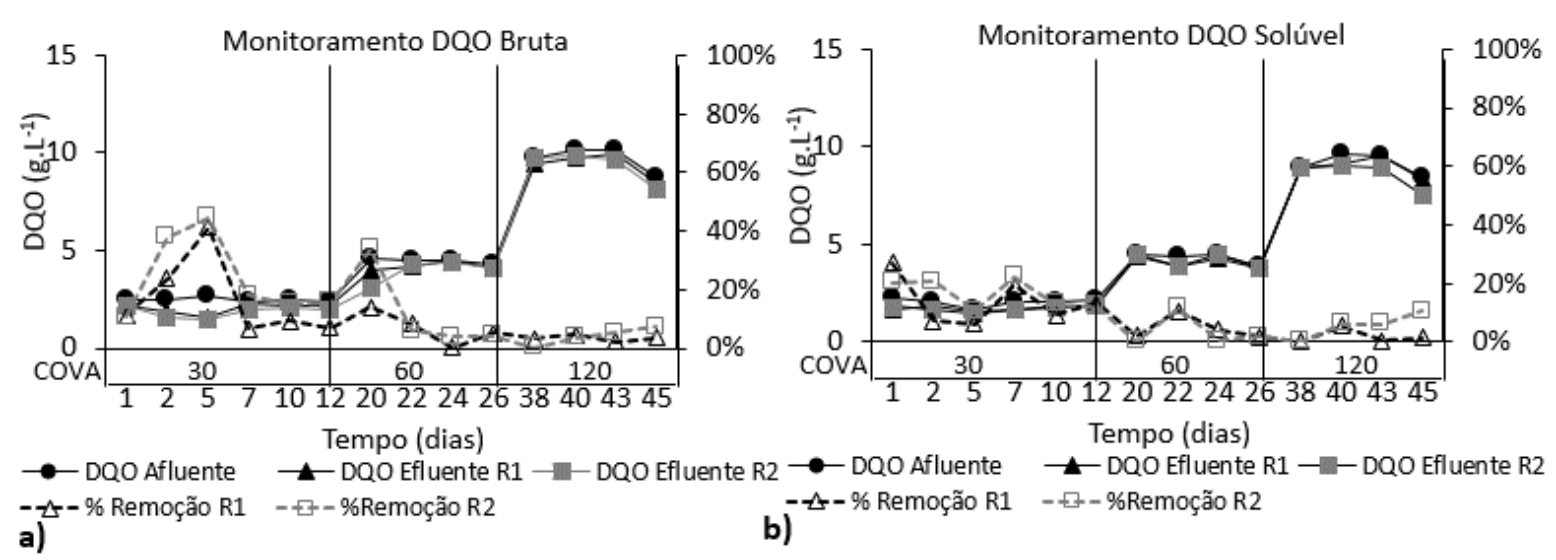

Figura 8: Monitoramento da remoção de DQO; a) Monitoramento temporal da remoção de DQO Bruta, b) Monitoramento temporal da remoção de DQO Solúvel.

Os valores de remoção de DQO nas COV de 30, 60 e 120 gDQO.Lreator ${ }^{-1}$.dia ${ }^{-1}$, ficaram em média de $29,78 \%, 48,80 \%$ e $34,72 \%$ em R1 e $70,02 \%, 69,48 \%$ e $55,27 \%$ em R2 respectivamente (Figura 9a).

A conversão global de carboidratos para o reator R2 apresentou média de 70\%, acima de R1 com 55\% (Figura 9b). 
80
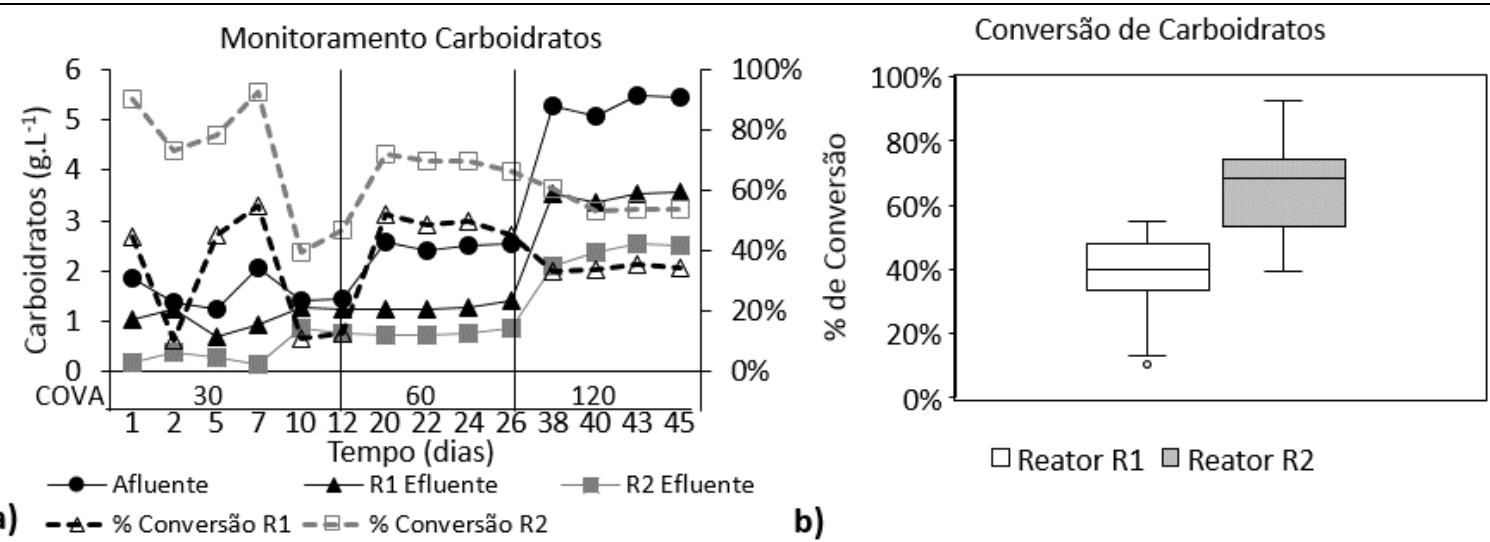

b)

Figura 9: Monitoramento da conversão de carboidratos, a) Monitoramento temporal da conversão de carboidratos, b) Análise estatística de boxplot monitoramento da conversão global de carboidratos.

A Tabela 8 apresenta a média dos parâmetros monitorados na primeira etapa de operação com carga de 30gDQO.Lreator ${ }^{-1} \cdot \mathrm{dia}^{-1}$.

Tabela 8: Valores obtidos no monitoramento dos parâmetros afluente e efluente de R1 e R2 na primeira fase de operação com carga de 30gDQO.Lreator ${ }^{-1}$.dia ${ }^{-1}$.

\begin{tabular}{|c|c|c|c|c|}
\hline \multicolumn{5}{|c|}{ Carga Orgânica Volumétrica Aplicada (COV) 30 gDQO.Lreator ${ }^{-1}$.dia ${ }^{-1}$} \\
\hline Parâmetro & & Afluente & R1 & R2 \\
\hline \multirow{3}{*}{$\mathrm{pH}$} & Média & 5,55 & 4,08 & 3,96 \\
\hline & Máximo & 6,67 & 4,65 & 4,03 \\
\hline & Desvio Padrão & $\pm 0,84$ & $\pm 0,31$ & $\pm 0,06$ \\
\hline \multirow{3}{*}{ Ácidos Totais* $\left(\mathrm{mg} . \mathrm{L}^{-1}\right)$} & Média & 56 & 196 & 254 \\
\hline & Máximo & 67 & 250 & 298 \\
\hline & Desvio Padrão & \pm 9 & \pm 56 & \pm 39 \\
\hline \multirow{3}{*}{ Carga de ácidos (gAGV.dia $\left.{ }^{-1}\right)$} & Média & 0,70 & 2,35 & 3,00 \\
\hline & Máximo & 0,80 & 3,00 & 3,60 \\
\hline & Desvio Padrão & $\pm 0,11$ & $\pm 0,70$ & $\pm 0,50$ \\
\hline \multirow{3}{*}{ DQO 2,5 (g.L $\left.\mathrm{L}^{-1}\right)$} & Média & 2,50 & 2,00 & 2,00 \\
\hline & Máximo & 2,70 & 2,00 & 2,22 \\
\hline & Desvio Padrão & $\pm 0,10$ & $\pm 0,27$ & $\pm 0,30$ \\
\hline \multirow{3}{*}{ Carboidratos Totais (g.L $\mathrm{L}^{-1}$ ) } & Média & 1,56 & 1,06 & 0,43 \\
\hline & Máximo & 2,06 & 1,27 & 0,86 \\
\hline & Desvio Padrão & $\pm 0,32$ & $\pm 0,23$ & $\pm 0,31$ \\
\hline
\end{tabular}

Tabela 9 apresenta a média dos parâmetros monitorados na primeira etapa de operação com carga de $60 \mathrm{gDQO} \cdot$ Lreator $^{-1} \cdot \mathrm{dia}^{-1}$. 
Tabela 9: Valores obtidos no monitoramento dos parâmetros afluente e efluente de R1 e R2 na primeira fase de operação com carga de 60gDQO.Lreator ${ }^{-1} \cdot$ dia $^{-1}$.

\begin{tabular}{|c|c|c|c|c|}
\hline \multicolumn{5}{|c|}{ Carga Orgânica Volumétrica Aplicada (COV) 60 gDQO.Lreator ${ }^{-1}$. dia $^{-1}$} \\
\hline \multicolumn{2}{|c|}{ Parâmetro } & Afluente & R1 & $\mathbf{R 2}$ \\
\hline \multirow{3}{*}{$\mathrm{pH}$} & Média & 5,11 & 4,13 & 4,20 \\
\hline & Máximo & 5,75 & 4,45 & 4,32 \\
\hline & Desvio Padrão & $\pm 0,49$ & $\pm 0,22$ & $\pm 0,13$ \\
\hline \multirow{3}{*}{ Ácidos Totais (mg.L $\left.\mathrm{L}^{-1}\right)$} & Média & 156 & 212 & 253 \\
\hline & Máximo & 192 & 271 & 30 \\
\hline & Desvio Padrão & \pm 47 & \pm 59 & \pm 73 \\
\hline \multirow{3}{*}{ Carga de ácidos (gAGV.dia $\left.{ }^{-1}\right)$} & Média & 1,90 & 2,50 & 3,00 \\
\hline & Máximo & 2,30 & 3,20 & 3,60 \\
\hline & Desvio Padrão & $\pm 0,40$ & $\pm 0,80$ & $\pm 1,00$ \\
\hline \multirow{3}{*}{ DQO $5\left(\right.$ g. $\left.\mathrm{L}^{-1}\right)$} & Média & 4,49 & 4,18 & 3,95 \\
\hline & Máximo & 4,60 & 4,53 & 4,37 \\
\hline & Desvio Padrão & $\pm 0,96$ & $\pm 0,92$ & $\pm 1,03$ \\
\hline \multirow{3}{*}{ Carboidratos Totais (g. $\mathrm{L}^{-1}$ ) } & Média & 2,51 & 1,28 & 0,77 \\
\hline & Máximo & 2,58 & 1,39 & 0,85 \\
\hline & Desvio Padrão & $\pm 0,48$ & $\pm 0,06$ & $\pm 0,05$ \\
\hline
\end{tabular}

Tabela 10 apresenta a média dos parâmetros monitorados na primeira etapa de operação com carga de $120 \mathrm{gDQO}$.Lreator ${ }^{-1}$. $\mathrm{dia}^{-1}$.

Tabela 10: Valores obtidos no monitoramento dos parâmetros afluente e efluente de R1 e R2 na primeira fase de operação com carga de 120gDQO.Lreator ${ }^{-1}$.dia ${ }^{-1}$.

\begin{tabular}{|c|c|c|c|c|}
\hline \multicolumn{5}{|c|}{ Carga Orgânica Volumétrica Aplicada (COV) 120 gDQO.Lreator ${ }^{-1}$.dia ${ }^{-1}$} \\
\hline \multicolumn{2}{|c|}{ Parâmetro } & Afluente & R1 & $\mathbf{R 2}$ \\
\hline \multirow{3}{*}{$\mathrm{pH}$} & Média & 5,27 & 4,16 & 4,25 \\
\hline & Máximo & 6,00 & 4,27 & 4,57 \\
\hline & Desvio Padrão & $\pm 0,64$ & $\pm 0,10$ & $\pm 0,23$ \\
\hline \multirow{3}{*}{ Ácidos Totais (mg. $\left.\mathrm{L}^{-1}\right)$} & Média & 205 & 365 & 428 \\
\hline & Máximo & 295 & 383 & 479 \\
\hline & Desvio Padrão & \pm 62 & \pm 21 & \pm 58 \\
\hline \multirow{3}{*}{ Carga de ácidos (gAGV.dia $\left.{ }^{-1}\right)$} & Média & 2,50 & 4,40 & 5,10 \\
\hline & Máximo & 3,50 & 4,60 & 5,75 \\
\hline & Desvio Padrão & $\pm 0,75$ & $\pm 0,30$ & $\pm 0,70$ \\
\hline \multirow{3}{*}{ DQO $10\left(\mathrm{~g} . \mathrm{L}^{-1}\right)$} & Média & 9,72 & 9,39 & 9,33 \\
\hline & Máximo & 10,19 & 9,97 & 9,80 \\
\hline & Desvio Padrão & $\pm 0,69$ & $\pm 0,68$ & $\pm 0,83$ \\
\hline \multirow{3}{*}{ Carboidratos Totais $\left(\mathrm{g} . \mathrm{L}^{-1}\right)$} & Média & 5,32 & 3,49 & 2,38 \\
\hline & Máximo & 5,47 & 3,56 & 2,54 \\
\hline & Desvio Padrão & $\pm 0,19$ & $\pm 0,09$ & $\pm 0,20$ \\
\hline
\end{tabular}


Como observado nos dados obtidos do desempenho dos reatores, ambos se mostraram eficientes na acidogênese, no entanto com vantagem para o Reator R2.

Para o levantamento das produções de hidrogênio, tanto a produção bruta de hidrogênio $\left(\mathrm{PBH}_{2}\right)$ quanto para a produção volumétrica de hidrogênio $\left(\mathrm{PVH}_{2}\right)$, foram calculados apenas para as COV de 60 e 120 gDQO.Lreator ${ }^{-1} \cdot \mathrm{dia}^{-1}$. Devido a problemas operacionais, não foi possível mensurar os volumes de $\mathrm{H}_{2}$ gerados na COV de 30 gDQO.Lreator ${ }^{-1}$. dia $^{-1}$, dado essencial para os cálculos das produções $\left(\mathrm{PBH}_{2}\right.$ e $\left.\mathrm{PVH}_{2}\right)$.

Em relação às produções de hidrogênio em R1 e R2 para $\mathrm{PBH}_{2}$ e $\mathrm{PVH}_{2}$, os gráficos de se assemelham, pois, estas produções estão intimamente relacionadas entre si. Observa-se pequena oscilação e aumento da produção em $\mathrm{PBH}_{2}$ (Figura $10 \mathrm{a}$ b) e em $\mathrm{PVH}_{2}$ (Figura 10 c d) no incremento COV, tanto para R1 quanto para R2.

No entanto, a $\mathrm{PBH}_{2}$ e $\mathrm{PVH}_{2}$ em R2 foi superior comparada a $\mathrm{R} 1$ em aproximadamente 88\%, conforme apontam os principais dados da produção de Hidrogênio na Tabela 11.
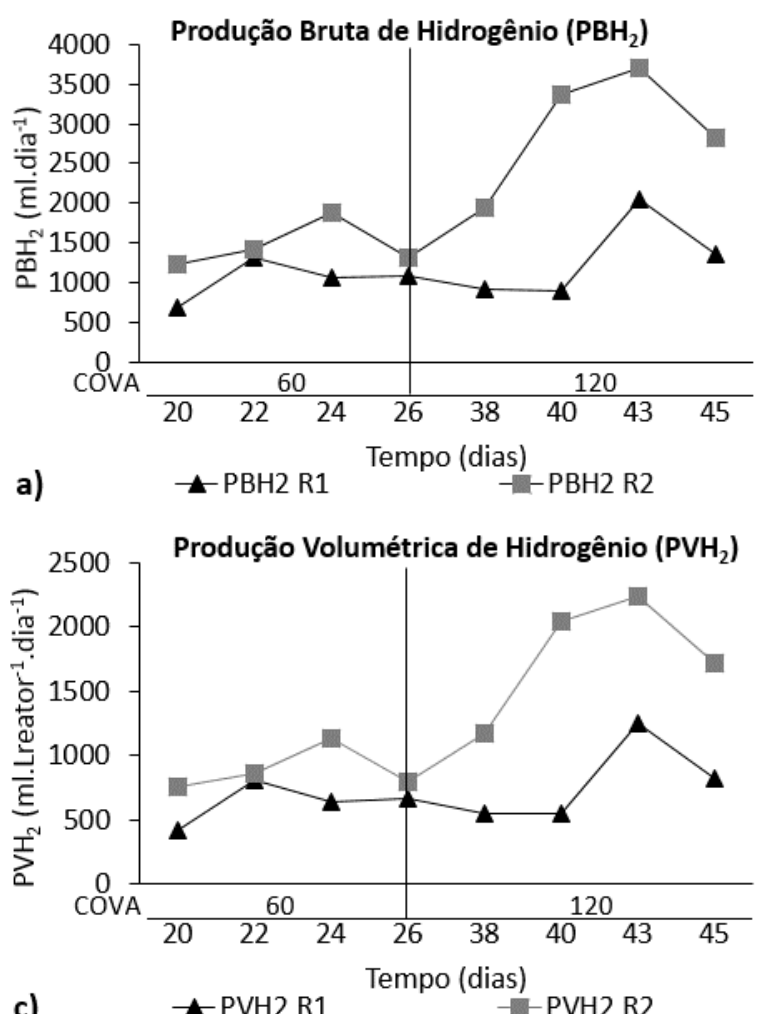
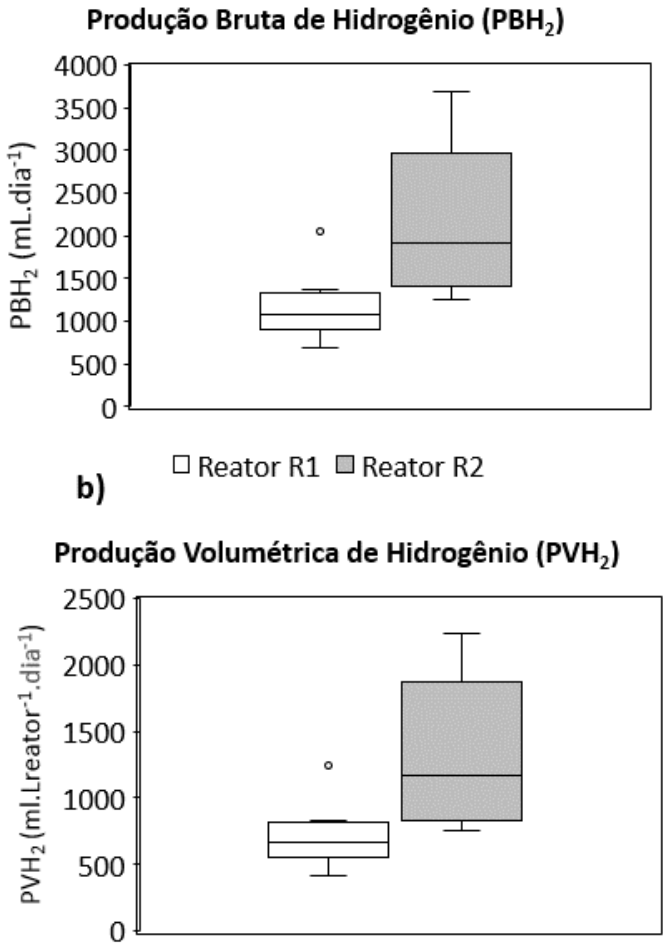

d)

Figura 10: Produção de hidrogênio; a) Variação temporal da produção bruta de hidrogênio $\left(\mathrm{PBH}_{2}\right)$, b) Análise estatística de boxplot da $\mathrm{PBH}_{2}$, c) Variação temporal da produção volumétrica de hidrogênio $\left(\mathrm{PVH}_{2}\right)$, d) Análise estatística de boxplot da $\mathrm{PVH}_{2}$. 
Tabela 11: Comparativo das produções de hidrogênio $\left(\mathrm{PBH}_{2}\right.$ e $\left.\mathrm{PVH}_{2}\right)$ entre os reatores acidogênicos

\begin{tabular}{|c|c|c|c|}
\hline \multicolumn{4}{|c|}{ Avaliação da Produção de Hidrogênio } \\
\hline \multirow{2}{*}{\multicolumn{2}{|c|}{ Parâmetro de Produção de $\mathbf{H}_{2}$}} & \multicolumn{2}{|c|}{ Reatores } \\
\hline & & R1 & $\mathbf{R 2}$ \\
\hline \multirow{4}{*}{$\begin{array}{l}\text { Produção Bruta de Hidrogênio } \\
\mathrm{PBH}_{2}\left(\mathrm{mlH}_{2} \cdot \mathrm{dia}^{-1}\right)\end{array}$} & Média & 1176 & 2212 \\
\hline & Máximo & 2059 & 3698 \\
\hline & Mínimo & 684 & 1243 \\
\hline & Desvio Padrão & \pm 421 & \pm 960 \\
\hline \multirow{4}{*}{$\begin{array}{l}\text { Produção Volumétrica de Hidrogênio } \\
\mathrm{PVH}_{2}\left(\mathrm{mlH}_{2} \text {.Lreator }{ }^{-1} \cdot \text { dia }^{-1}\right)\end{array}$} & Média & 713 & 1341 \\
\hline & Máximo & 1248 & 2241 \\
\hline & Mínimo & 415 & 753 \\
\hline & Desvio Padrão & \pm 256 & \pm 581 \\
\hline
\end{tabular}

Analisou-se a influência da carga orgânica volumétrica aplicada (COV) sobre a produção bruta de hidrogênio $\left(\mathrm{PBH}_{2}\right)$, por meio da análise do coeficiente de correlação e ajuste polinomial de $2^{\mathrm{a}}$ ordem. Os dados apresentaram uma baixa correlação entre a $\mathrm{COV}$ e $\mathrm{PBH}_{2}$ para ambos os reatores R1 e R2. Os gráficos de correlação apontam que com o aumento de carga orgânica volumétrica aplicada (COV) aos reatores, houve aumento da produção de hidrogênio no reator R2, embora tenha sido imposta a mesma estratégia do reator R1. Dados de $\mathrm{PBH}_{2} \mathrm{em}$ função da carga (Figura 10) indicaram que em R1, apesar do aumento de carga não houve aumento de $\mathrm{PBH} 2$, diferentemente de R2, em que o aumento de carga praticamente triplicou $\mathrm{PBH}_{2}$. $\mathrm{O}$ ajuste polinomial de $2^{\mathrm{a}}$ ordem mostrou que a equação do coeficiente de correlação se aproximou em $81 \%$ em R1 (Figura 11a) e 94\% em R2 (Figura 11b).

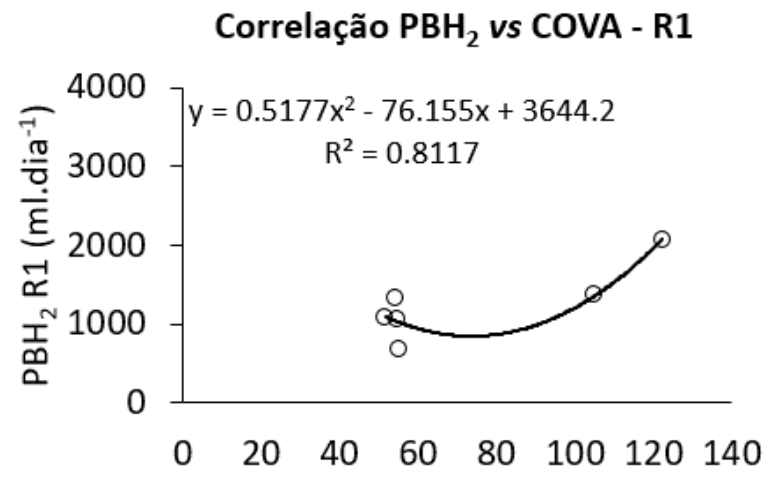

a)

COVA (gDQO.Lreator ${ }^{-1} \cdot \mathrm{dia}^{-1}$ ) b)

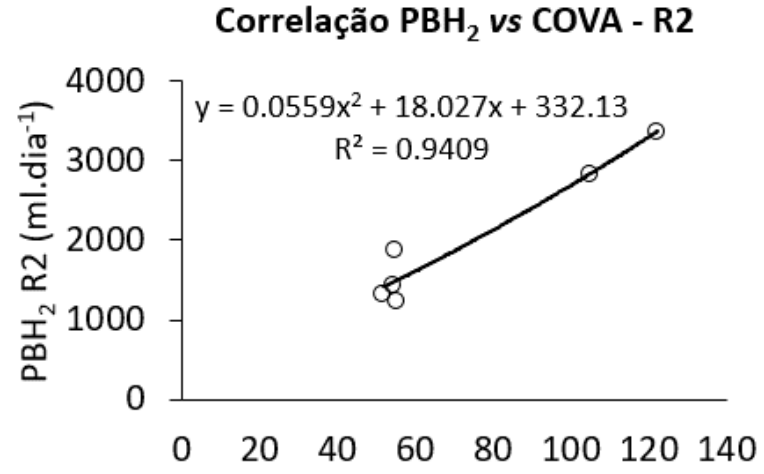

Correlação $\mathrm{PBH}_{2}$ vs COVA - R2

COVA (gDQO.Lreator ${ }^{-1} \cdot \mathrm{dia}^{-1}$ )

Figura 11: Análise estatística do coeficiente de correlação e ajuste polinomial de $2^{\mathrm{a}}$ ordem entre a produção de hidrogênio e carga orgânica volumétrica aplicada; a) Correlação $\mathrm{PBH}_{2}$ $\mathrm{R} 1$ vs COV para R1, b) Correlação $\mathrm{PBH}_{2} \mathrm{R} 2$ vs COV para R2. 
84

As populações desenvolvidas a partir de diferentes inóculos apresentaram diferentes produções de $\mathrm{H}_{2}$. A Figura 11a e a Figura $11 \mathrm{~b}$ evidenciam que em R1, apesar do aumento de carga não houve aumento significativo de $\mathrm{PBH}_{2}$, diferentemente de $\mathrm{R} 2$, em que o aumento de carga praticamente triplicou o valor de $\mathrm{PBH}_{2}$. Seguindo a premissa às modificações impostas durante a operação desta etapa, ou seja, aplicação da estratégia operacional de aumento de $\mathrm{COV}$, provavelmente promoveram alterações na comunidade microbiana acidogênica incialmente estabelecida nos reatores.

A correlação entre a geração de ácidos totais e a produção bruta de hidrogênio aponta que em R1 a $\mathrm{PBH}_{2} \mathrm{R} 1$ (Figura 12a) foi inferior a $\mathrm{PBH}_{2} \mathrm{R} 2$ em R2 (Figura 12b), que nesta $\left(\mathrm{PBH}_{2} \mathrm{R} 2\right)$ houve maior produção e consequentemente maior concentração de ácidos voláteis, a partir da conversão de carboidratos. Dado confirmado pelo ajuste polinomial de $2^{\mathrm{a}}$ ordem em que a equação do coeficiente de correlação entre a geração de ácidos totais e a produção bruta de hidrogênio se aproxima em $84 \%$ em $\mathrm{PBH}_{2} \mathrm{R} 1$ e $92 \%$ em $\mathrm{PBH}_{2} \mathrm{R} 2$.
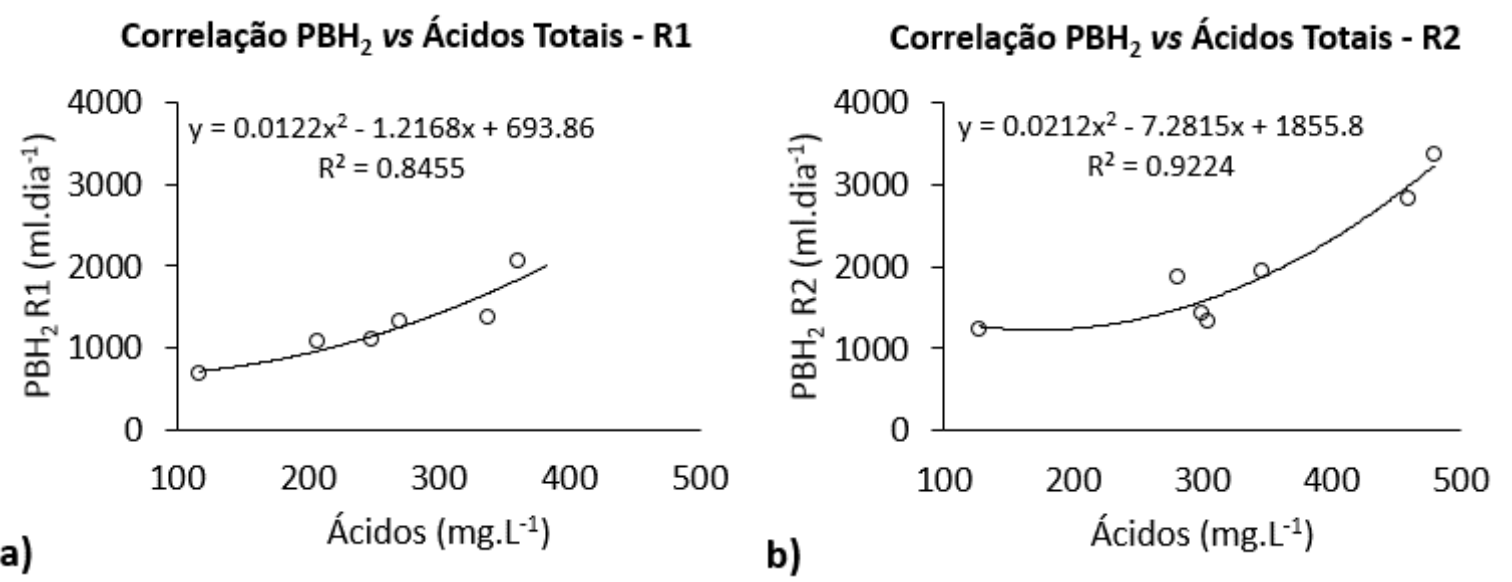

Figura 12: Análise estatística do coeficiente de correlação e ajuste polinomial de $2^{\mathrm{a}}$ ordem entre a produção de hidrogênio e a geração de ácidos toais gerados; a) Correlação $\mathrm{PBH}_{2} \mathrm{R} 1$ $v s$ ácidos totais $\mathrm{R} 1, \mathbf{b})$ Correlação $\mathrm{PBH}_{2} \mathrm{R} 2$ vs ácidos totais $\mathrm{R} 2$.

Conforme aumento na produção de ácidos totais em R2, houve aumento da produção de hidrogênio, sendo que o inverso ocorreu para R1, quanto houve aumento de ácidos totais houve diminuição da produção de hidrogênio. Possivelmente houve desvio de rotas metabólicas dos ácidos orgânicos envolvidos na produção de hidrogênio, de acordo com a equações estequiométricas propostas por Antonopoulou et al. (2008), tanto para a geração de $\mathrm{H}_{2}$ pela via fermentativa do tipo ácido acético (Equação 29) e butírico (Equação 30), quanto para o consumo de $\mathrm{H}_{2}$ pela via do ácido propiônico (Equação 31).

$\mathrm{C}_{6} \mathrm{H}_{12} \mathrm{O}_{6}+2 \mathrm{H}_{2} \mathrm{O} \rightarrow 2$ Acético $+2 \mathrm{CO}_{2}+4 \mathrm{H}_{2}$

Equação 29

$\mathrm{C}_{6} \mathrm{H}_{12} \mathrm{O}_{6} \rightarrow$ Butírico+2 $\mathrm{CO}_{2}+2 \mathrm{H}_{2}$

Equação 30

$\mathrm{C}_{6} \mathrm{H}_{12} \mathrm{O}_{6}+2 \mathrm{H}_{2} \rightarrow$ Propiônico $+2 \mathrm{H}_{2} \mathrm{O}$

Equação 31 
Resultado comprovado pela Tabela 12, conforme houve aumento de carga, ocorreu o acúmulo de ácido propiônico no reator R1.

Tabela 12: Avaliação dos Produtos Intermediários (valores de porcentagem de ácidos por fases)

\begin{tabular}{|c|c|c|c|c|c|c|}
\hline \multicolumn{7}{|c|}{ Avaliação das frações (\%) dos ácidos orgânicos no efluente dos reatores } \\
\hline \multirow{2}{*}{$\begin{array}{c}\text { Ácidos Orgânicos } \\
\text { Voláteis } \\
\end{array}$} & \multicolumn{3}{|c|}{ Reator R1 } & \multicolumn{3}{|c|}{ Reator R2 } \\
\hline & Fase I & Fase II & Fase III & Fase I & Fase II & Fase III \\
\hline Ácido Acético (\%) & 35 & 32 & 17 & 38 & 36 & 70 \\
\hline Ácido Butírico (\%) & 14 & 35 & 19 & 40 & 37 & 25 \\
\hline Ácido Propiônico (\%) & 47 & 32 & 63 & 21 & 26 & 05 \\
\hline
\end{tabular}

Observa-se pela análise estatística do conjunto das cargas aplicadas que a produção de hidrogênio pela fermentação do tipo Acético/Butírico foi dominante na operação do reator R2 (Figura 13b), enquanto a via metabólica do ácido propiônico que é desfavorável para a produção de hidrogênio, foi associada à baixa produção de $\mathrm{H}_{2}$ no reator R1 (Figura 13a).

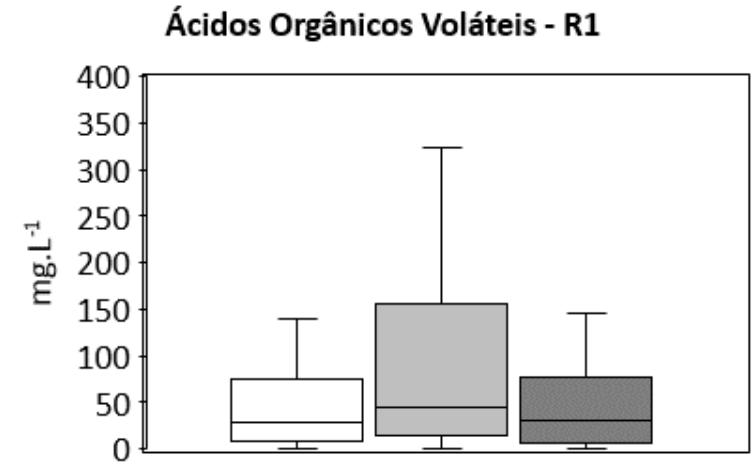

a)

$\square$ Acético $\square$ Propiônico $\square$ Butírico

Carga de Ácidos - R1

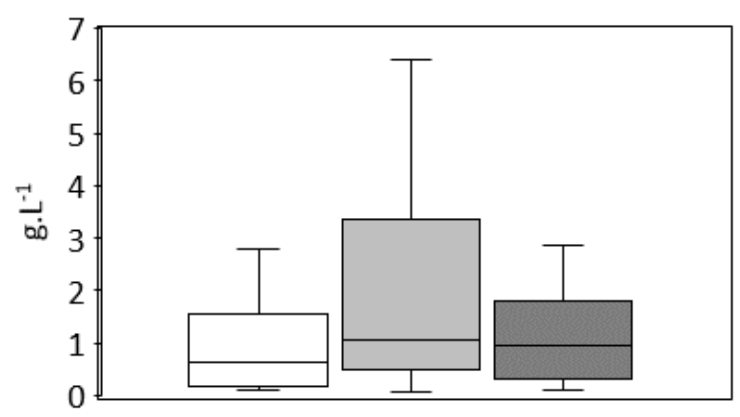

c) $\square$ Acético $\square$ Propiônico $\square$ Butírico

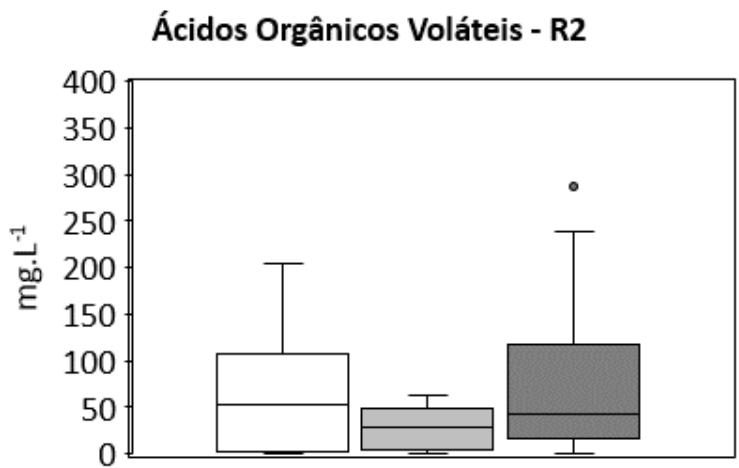

b)

$\square$ Acético $\square$ Propiônico $\square$ Butírico

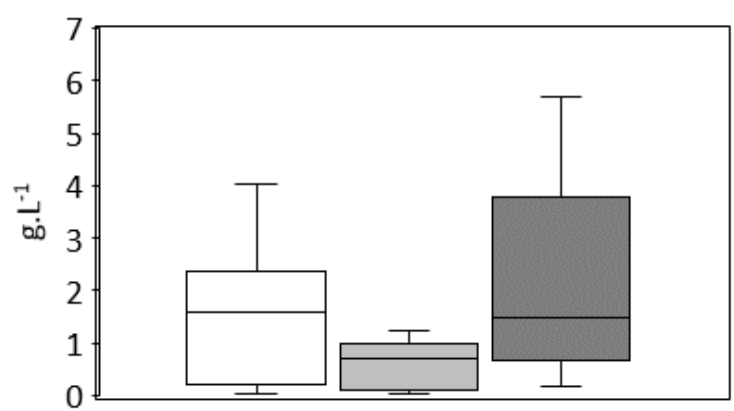

d) $\square$ Acético $\square$ Propiônico $\square$ Butírico

Figura 13: Análise estatística de boxplot da geração de ácidos orgânicos de interesse para a produção de hidrogênio; a) Ácidos orgânicos voláteis produzidos em R1, b) Ácidos orgânicos voláteis produzidos em R2, c) Concentração de ácidos efluente pela vazão aplicada em R1, d) Concentração de ácidos efluente pela vazão aplicada em R2. 
Outra hipótese que explica a reduzida produção de $\mathrm{H}_{2}$ em $\mathrm{R} 1$, pode ser creditada ao estabelecimento de populações microbianas homoacetogênicas no reator, as quais também empregam o $\mathrm{CO}_{2}$ no crescimento autotrófico pela rota de Wood-Ljungdahl, utilizando-se do hidrogênio molecular como doador de elétron (FONTES LIMA et al., 2012; ANZOLA-ROJAS et al., 2015; FERRAZ et al., 2015).

Outro fator que pode ser observado pela composição do biogás em R1 (Figura 14a), em que a produção média de $\mathrm{H}_{2}(57,19 \%)$ e de $\mathrm{CO}_{2}(42,81 \%)$, foi inferior a médias observadas em R2 (Figura 14b) com médias de produção de $65,5 \%$ de $\mathrm{H}_{2}$ de $34,5 \%$ de $\mathrm{CO}_{2}$, comprovadas pelas análises de boxplot da composição do biogás apresentadas nas Figura 14c e Figura 14d.

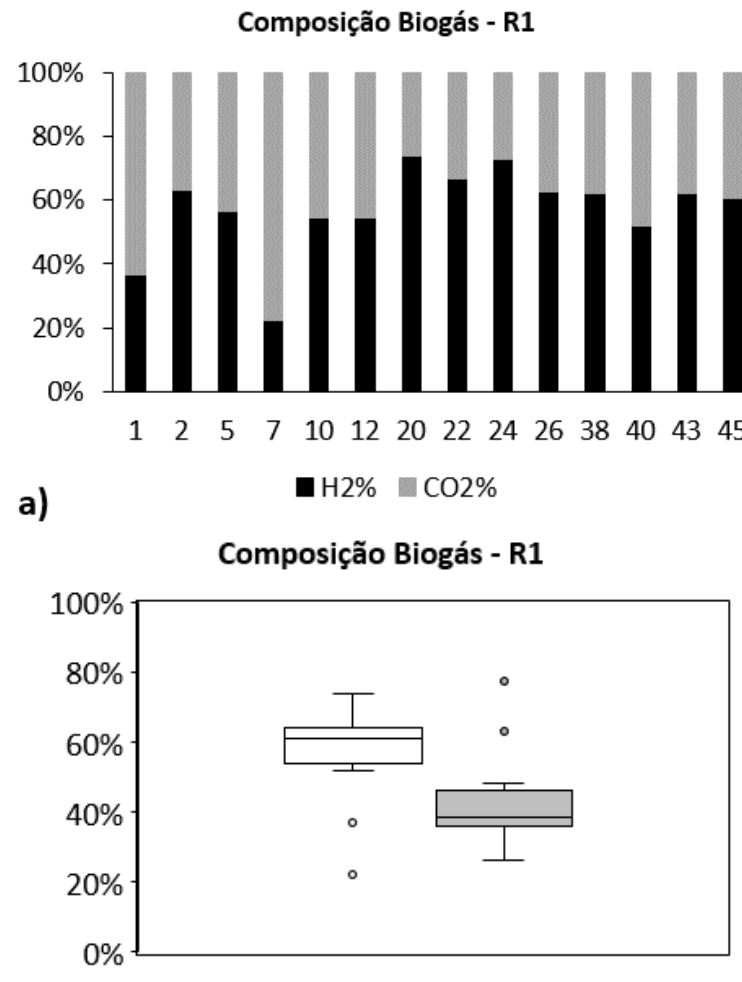

c) $\square$ Hidrogênio $\square$ Dióxido de Carbono

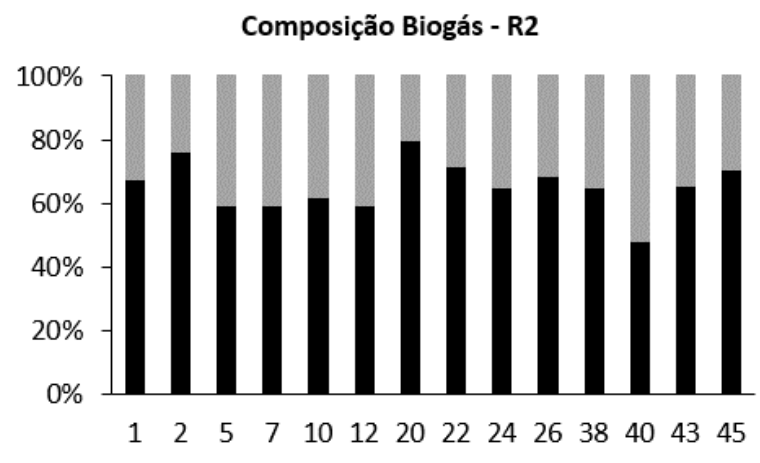

b)

- $\mathrm{H} 2 \%=\mathrm{CO} 2 \%$

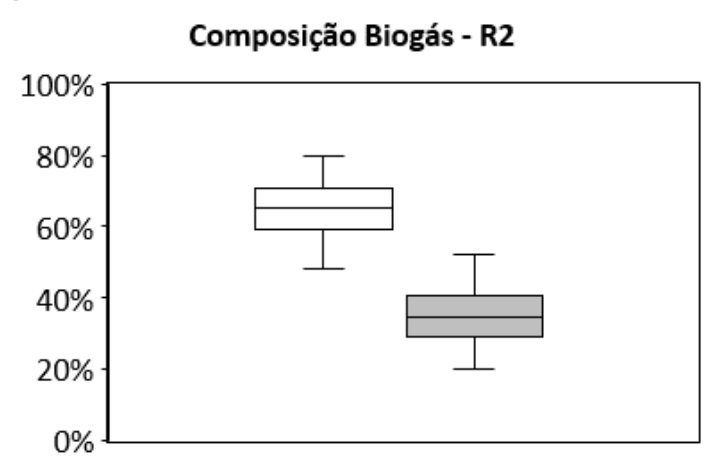

d) $\square$ Hidrogênio $\square$ Dióxido de Carbono

Figura 14: Composição do biogás nos reatores acidogênicos; a) Composição do biogás R1, b) Composição do biogás R2, c) Análise estatística de boxplot da composição do biogás reator R1, d) Análise estatística de boxplot da composição do biogás reator R2.

Em resumo podemos creditar as seguintes hipóteses para a menor produção de $\mathrm{H}_{2} \mathrm{em}$ R1 do que em R2, menor conversão de carboidratos; acumulo de ácido propiônico (desvio de rota da produção de $\mathrm{H}_{2}$ ) e utilização do $\mathrm{H}_{2}$ pela população desenvolvida no reator $\mathrm{R}$, a partir do inóculo. 
De acordo com a Tabela 13, observa-se que não houve geração de metano em ambos os reatores durante todo o período de operação (45 dias), mostrando que as estratégias adotadas foram eficazes na inibição da metanogênese e consequentemente favorecendo a acidogênese.

Tabela 13: Valores de composição do biogás nos reatores acidogênicos

\begin{tabular}{llcc}
\hline \multicolumn{3}{c}{ Composição do Biogás dos Reatores Acidogênicos } \\
\cline { 3 - 4 } \multicolumn{2}{c}{ Reatores } & \multicolumn{2}{c}{ Biogás } \\
\cline { 2 - 4 } & Média & $\mathbf{H}_{2}$ & $\mathbf{C O}_{2}$ \\
\hline \multirow{3}{*}{ Composição do Biogás } & $57,19 \%$ & $42,81 \%$ \\
Reator R1 & Máximo & $73,66 \%$ & $77,70 \%$ \\
& Mínimo & $22,30 \%$ & $26,34 \%$ \\
& Desvio Padrão & $\pm 0,13$ & $\pm 0,13$ \\
\hline \multirow{3}{*}{ Composição do Biogás } & Máximo & $65,54 \%$ & $34,46 \%$ \\
Reator R2 & Média & $79,86 \%$ & $52,01 \%$ \\
& Mínimo & $47,99 \%$ & $20,14 \%$ \\
& Desvio Padrão & $\pm 0,08$ & $\pm 0,08$ \\
\hline
\end{tabular}

\subsubsection{Análise Comparativa Biomoleculares dos Reatores Acidogênicos}

\subsubsection{Perfil da Comunidade de Bactéria pela Técnica de PCR-DGGE}

A análise biomolecular da técnica de DGGE foi realizada na comunidade bacterina do material suporte dos reatores R1 e R2. As amostras para o perfil da comunidade bacteriana foram coletadas no inóculo e durante o aumento de COV aplicada aos reatores 60 e 120 gDQO.Lreator ${ }^{-1} \cdot$ dia $^{-1}$.

Estatisticamente foi realizado o índice de correlação de Pearson, que demonstra quais amostras são similares e qual a porcentagem desta similaridade.

Os resultados obtidos auxiliaram na construção do dendograma (Figura 15) que apontou similaridade de $72 \%$ entre os inóculos de R1 e R2, demonstrando a presença de grupos semelhantes de bactérias entre a vinhaça autofermentada (R1) e o lodo de reator UASB tratando vinhaça da cana-de-açúcar (R2). 


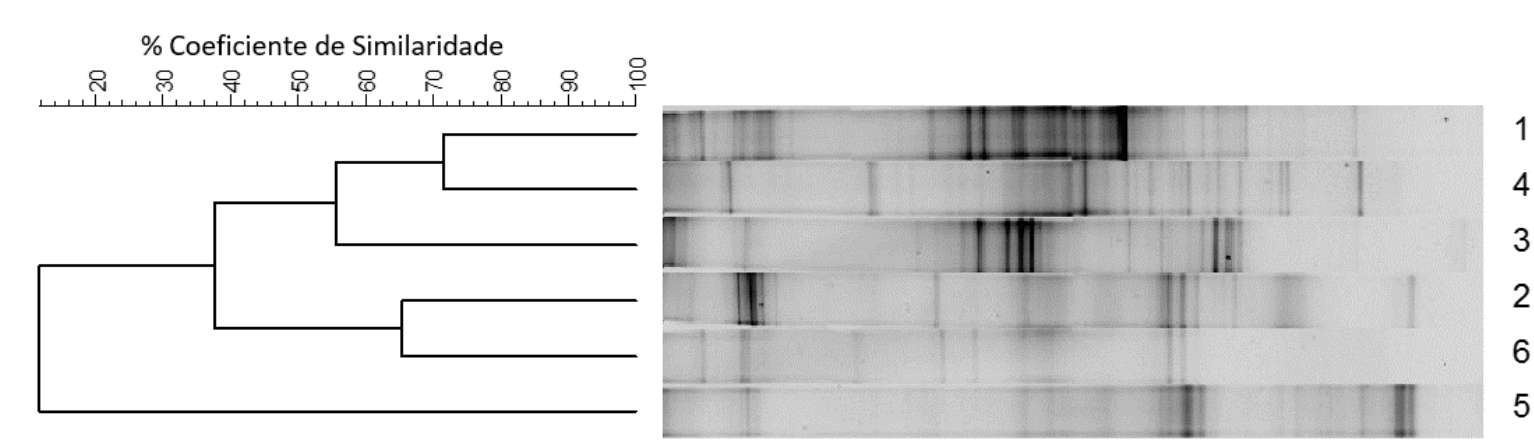

Figura 15: DGGE comparativos dos reatores acidogênicos; 1) Inóculo R1, 2) R1 COV 60 gDQO.Lreator ${ }^{-1} \cdot$ dia $^{-1}$, 3) R1 120 gDQO.Lreator ${ }^{-1} \cdot$ dia $^{-1}$, 4) Inóculo R2, 5) R2 COV 60 gDQO.Lreator ${ }^{-1} \cdot \mathrm{dia}^{-1}$; 6) R2 120 gDQO.Lreator ${ }^{-1} \cdot \mathrm{dia}^{-1}$.

Conforme aponta a Tabela 14, as condições de operação impostas ao reator, selecionou os organismos com capacidade de metabolizar efetivamente o melaço com carga orgânica volumétrica crescente, dado apontado pela baixa similaridade entre ambos os inóculos e as respectivas amostras no final da operação (55\% R1 e 40\% R2 respectivamente).

A seleção das espécies por grupos foi mais elevada em R2 comparada a R1, muito provavelmente pela fonte do inóculo aplicada. Baixos valores de similaridade (abaixo de 20\%) foram também observados entre os biorreatores, demostrando dessa maneira que o material suporte auxiliou na seleção dos microrganismos.

Tabela 14: Índices aplicados à técnica de DGGE

\begin{tabular}{lcccccccc}
\hline \multirow{2}{*}{ Índices Aplicados } & \multicolumn{3}{c}{ Reator R1 } & & \multicolumn{3}{c}{ Reator R2 } \\
\cline { 2 - 4 } & In & II & III & & In & II & III \\
\hline Shannon (H) & 2,91 & 3,10 & 3,36 & & 2,84 & 2,49 & 3,29 \\
\hline Dominância (D) & 0,06 & 0,05 & 0,04 & & 0,06 & 0,09 & 0,04
\end{tabular}

Legenda: Reator R1 In - inóculo, II - 60 e III - 120 gDQO.Lreator ${ }^{-1}$.dia ${ }^{-1}$; Reator R2 In inóculo, II - 60 e III - 120 gDQO.Lreator ${ }^{-1} \cdot$ dia $^{-1}$.

Não foi observada por esta técnica à amplificação do DNA, mesmo com primers específicos das arquéias metanogênicas. Demostrando possivelmente a abstenção ou baixo número de cópias dos genes das arquéias metanogênicas nos biorreatores, corroborando com os resultados de seleção dos organismos. 
5.1.2.2 Análise Biomolecular pela Técnica de PCR em tempo real (qPCR)

A técnica de biologia molecular de PCR em tempo real (qPCR) demonstrou de acordo com a (Figura 16), que o número dos genes quantificados pela análise biomolecular do rRNA 16S, alvo para o domínio bactéria, foi maior em R2 comparado ao R1, tanto para o inóculo e como para todas as condições operacionais impostas.

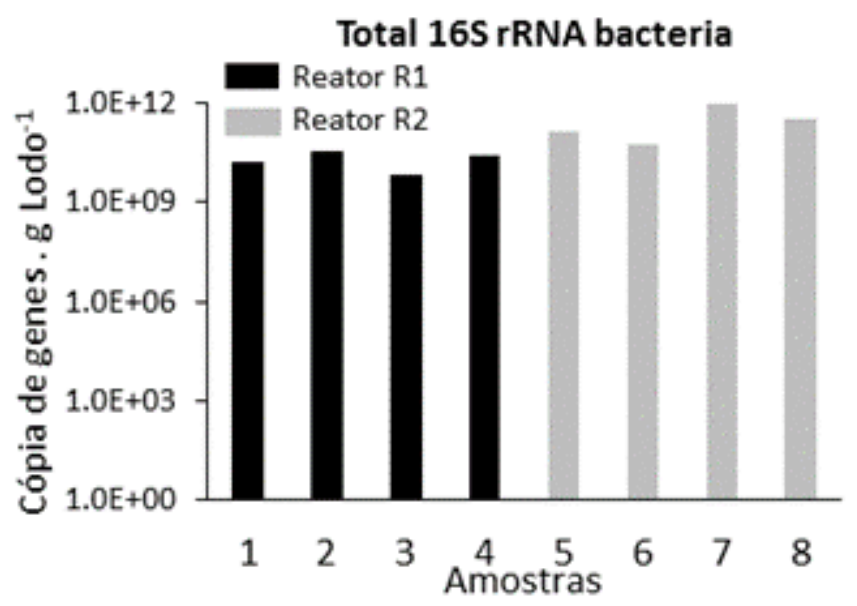

Figura 16: Número de cópias rRNA 16S para Bactérias, amostras: 1) Inóculo R1, 2) R1 30 gDQO.Lreator ${ }^{-1} \cdot \mathrm{dia}^{-1}$, 3) R1 60 gDQO.Lreator ${ }^{-1} \cdot \mathrm{dia}^{-1}$, 4) R1 120 gDQO.Lreator ${ }^{-1} \cdot \mathrm{dia}^{-1}$, 5) Inóculo R2, 6) R2 30 gDQO.Lreator ${ }^{-1} \cdot \mathrm{dia}^{-1}$, 7) R2 60 gDQO.Lreator ${ }^{-1}$.dia ${ }^{-1}$, 8) R2 120 gDQO.Lreator ${ }^{-1} \cdot$ dia $^{-1}$.

A Figura 18 também aponta que o aumento da COV não afetou significantemente o número das cópias dos genes do rRNA 16S. O montante de cópia dos genes foi maior nas fases operacionais do que nos inóculos aplicados, demonstrando assim que as fases operacionais impostas com melaço, favoreceram os microrganismos do domínio bactéria, incluindo as bactérias fermentativas e as produtoras de hidrogênio como observado nas análises da produção de ácidos voláteis e na Figura 17. Por esta Figura observa-se que o número de cópias do gene Fe hidrogenase, envolvido na produção de hidrogênio, esteve presente em todas as fases operacionais de R1 e R2 sendo maior o número de cópias para R2, corroborando com dos resultados de produção de hidrogênio. Para R1 as aplicações crescentes de COV praticamente não influenciaram o número de cópias do gene Fe hidrogenase. Para R2, houve aumento no número de genes Fe hidrogenase com aumento da COV aplicada. 


\section{Fe-hidrogenase}

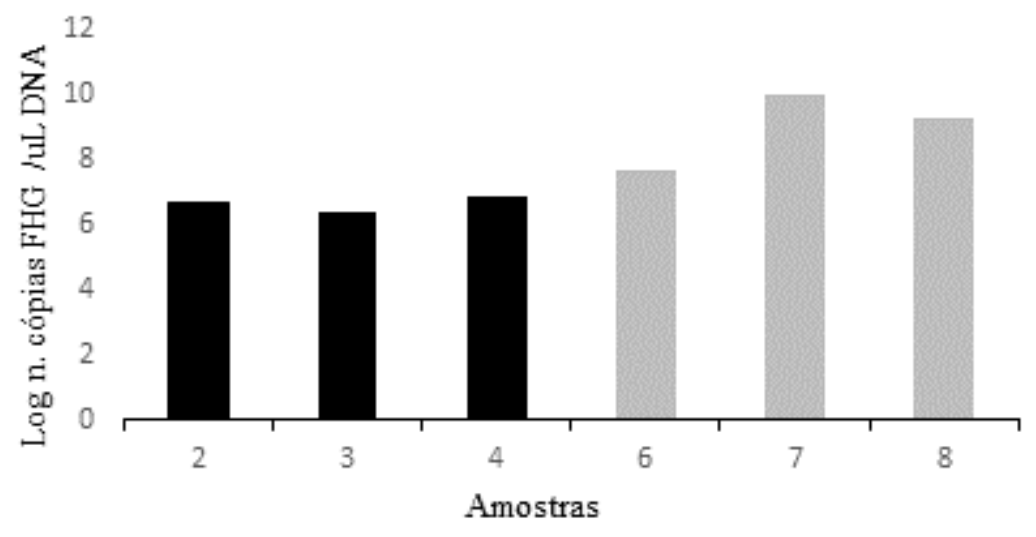

Figura 17: Gene Fe hidrogenase (FHG). Amostras: 2) R1 30 gDQO.Lreator ${ }^{-1}$.dia ${ }^{-1}$, 3) R1 60 gDQO.Lreator ${ }^{-1} \cdot \mathrm{dia}^{-1}$, 4) R1 120 gDQO.Lreator ${ }^{-1} \cdot \mathrm{dia}^{-1}$, 6) R2 30 gDQO.Lreator ${ }^{-1} \cdot \mathrm{dia}^{-1}$, 7) R2 60 gDQO.Lreator ${ }^{-1} \cdot$ dia $^{-1}$, 8) R2 120 gDQO.Lreator ${ }^{-1} \cdot$ dia $^{-1}$.

De acordo com a Figura 18a, as arquéias metanogênicas estavam presentes nos inóculos, tanto de R1 quanto de R2, e foram inibidas durante a operação do reator. O Grupo metanogênico (mcrA gene) estava presente apenas em R2 na fase operacional condição de COV de 30 gDQO.Lreator ${ }^{-1} \cdot \operatorname{dia}^{-1}$. Mesmo com a presença deste gene, metano não foi detectado nas análises de biogás no reator. Como aumento da COV, os genes de mcrA decresceram nas condições operacionais impostas, não sendo mais detectadas na condição de COV de 120 gDQO.Lreator ${ }^{-1} \cdot$ dia $^{-1}$ (Figura 18b).

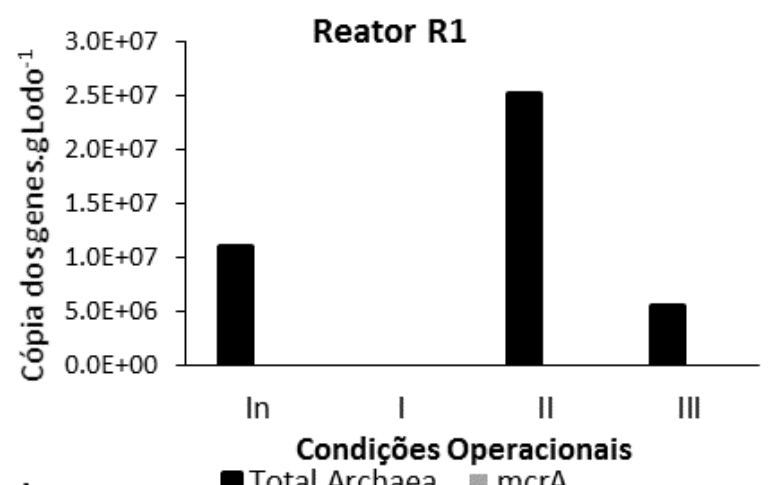

a)

Total Archaea mcrA

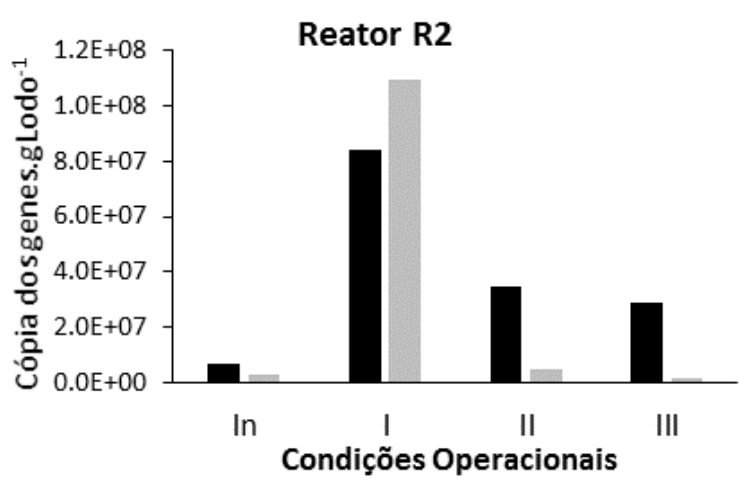

b)
- Total Archaea mcrA

Figura 18: Número de cópias do genes do inóculo e das amostras das diferentes cargas aplicadas ao reatores; a) R1 In - Inóculo, I - 30, II - 60 e III - 120 gDQO.Lreator ${ }^{-1}$.dia ${ }^{-1}$, b) R2 In - Inóculo, I - 30, II - 60 e III - 120 gDQO.Lreator ${ }^{-1}$.dia ${ }^{-1}$. 
Estes resultados de análises biomoleculares, juntamente com os resultados das análises de gases e ácidos voláteis orgânicos, demonstraram que a condição operacional de $55^{\circ} \mathrm{C}$ com aumento das COVA e o tempo de retenção hidráulico de 2 horas, foi adequado e favoreceu o metabolismo das bactérias fermentativas entre elas as produtoras de hidrogênio.

\subsubsection{Sequenciamento Metagenômico}

As sequencias resultantes de sequenciamento por metagenômica plataforma MiSeq passaram por uma análise de qualidade na qual foram removidas sequencias com Phred score abaixo de 30, foi permitido um máximo de 6 homopolímeros, não foi tolerado nenhuma base ambígua (“ $N$ ") na sequência, e todas as sequencias abaixo de 300 pb foram descartadas.

Para o reator acidogênico R1 (USBR1) foram analisadas 398289 sequencias do inóculo, 428238 para COV de 30gDQO.Lr-1 ${ }^{-1}$ dia $^{-1} ; 288621$ para COV de 60 gDQO. $\operatorname{Lr}^{-1} \cdot \operatorname{dia}^{-1} ; 369547$ para COV de $120 \mathrm{gDQO} \cdot \mathrm{Lr}^{-1} \cdot \mathrm{dia}^{-1}$.

Para o reator acidogênico R2 (USBR2) foram analisadas 333471 sequencias do inóculo, 330540 para COV de 30 gDQO.Lrr ${ }^{-1} \cdot$ dia $^{-1} ; 173160$ para COV de 60 gDQO.Lrr ${ }^{-1} \cdot$ dia $^{-1}$; e 241851 para COV de 120gDQO.Lr ${ }^{-1} \cdot \mathrm{dia}^{-1}$.

A Figura 19, apresenta os resultados obtidos para o conhecimento do sequenciamento metagenômico dos Filos nos reatores USBR1 e USBR2 referente aos inóculos e cada etapa operacional.

A Figura 19 mostra que no reator acidogênico R1 (USBR1) o inóculo, vinhaça autofermentada, foi composto praticamente pelo Filo Firmicutes (97\%) que permaneceu predominante durante todo o período operacional, ou seja com aumentos da COV aplicada. Os outros Filos foram Proteobacteria (1,5\% a 4\%) e em mínima frequência Archaea (menor que 1\%). Dentre as sequências relacionadas ao Filo Firmicutes no inóculo estão as de bactérias produtoras de ácido lático da Classe Bacili, tais como Lactobacillus (90\%) e Pediococcus (7,5\%) ambos da ordem Lactobacillales. Microrganismos destes gêneros são gram-positivos anaeróbios facultativos, produtores de ácido lático com espécies mesofilica e termofílicas. Microrganismos relacionados a outros gêneros cuja frequência foi menor que 4\% também estavam presentes. 


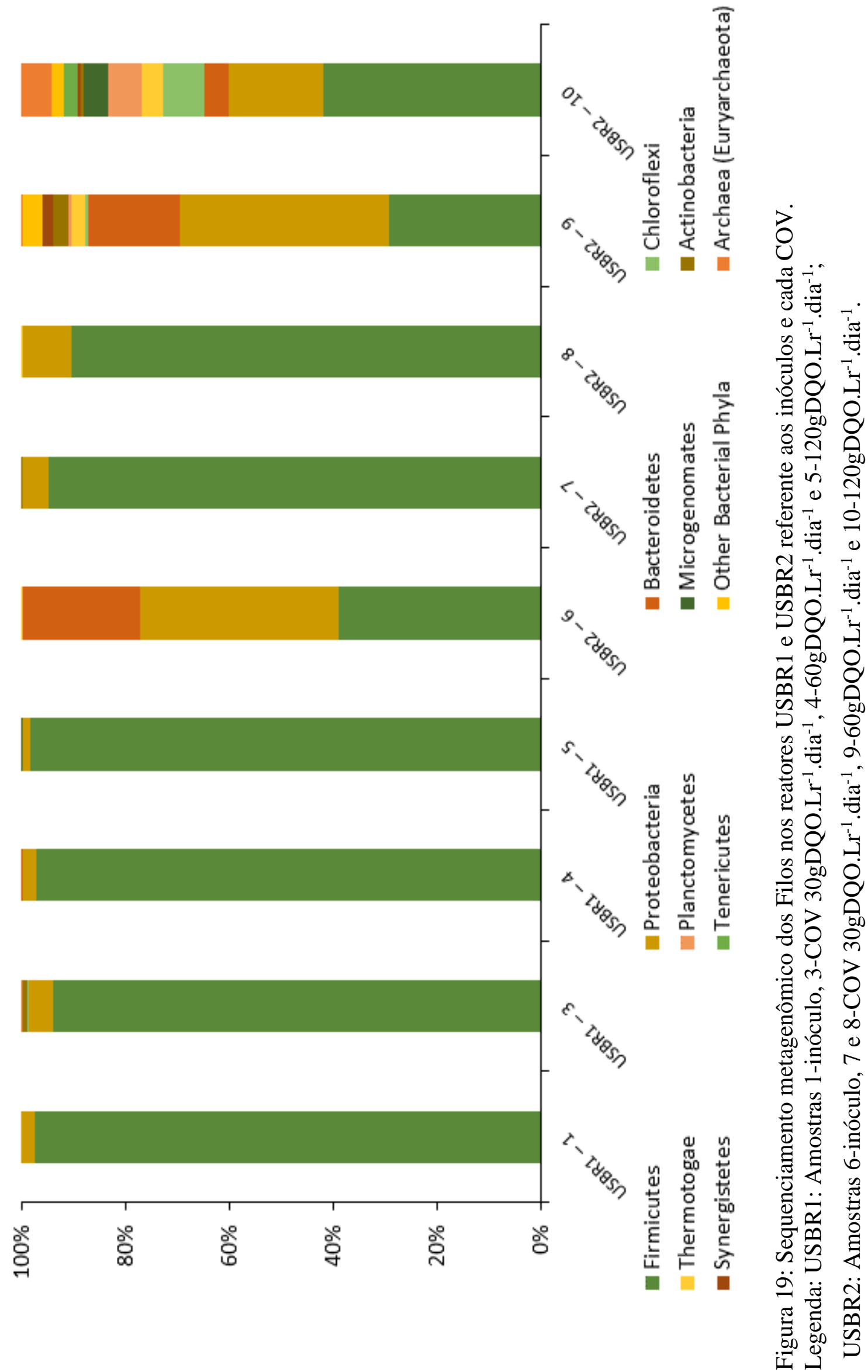


Com o decorrer da operação em ambiente termofílico e com aumento de COV houve seleção de sequências relacionadas a microrganismos reconhecidamente produtores de hidrogênio do Filo Firmicutes, Classe Clostridia, que estavam presentes no inóculo, mas em baixa frequência $(0,1 \%)$. Foram detectadas sequencias relacionadas principalmente aos gêneros Clostridium sensu stricto, Thermohydrogenium e Thermoanaerobacterium, conhecidos produtores de hidrogênio (KAPDAN e KARGI, 2006).

Na etapa I com COV aplicada de 30gDQO. $\operatorname{Lr}^{-1} \cdot \mathrm{dia}^{-1}$ houve a seleção de sequencias relacionadas principalmente a Clostridium sensu stricto (59\%) seguido de Thermohydrogenium (11\%) e em menor frequência Thermoanaerobacterium (2,8\%) e Ethanoligenens (3,5\%). Na etapa II, com COV aplicada de 60gDQO. $\mathrm{Lr}^{-1} \cdot \mathrm{dia}^{-1}$, houve a seleção de sequencias relacionadas a Thermoanaerobacterium (47,3\%) em detrimento de Clostridium sensu stricto (26,6\%). Na etapa III, COV aplicada de $120 \mathrm{gDQO} \cdot \mathrm{Lr}^{-1} \cdot \mathrm{dia}^{-1}$, observou-se diversidade microbiana semelhante à da etapa I, ambas maiores que a etapa II. Na etapa III houve seleção de Thermohydrogenium (34\%) seguida de Clostridium sensu stricto (26\%) e decaimento de Thermoanaerobacterium $(1,8 \%)$.

Tanto na etapa I quanto na etapa III, sequencias relacionadas a microrganismos produtores de ácido lático, pertencentes a Classe Bacili, também foram detectadas. Por exemplo, na etapa I Lactobacillus (8,9\%), Sporolactobacillus (2,2\%) e Leuconostoc $(1,8 \%)$. Interessante notar que na etapa III houve aumento do número de sequencias relacionadas a Leuconostoc (22\%), as demais continuaram em baixa frequência Lactobacillus (1,6\%\%), Sporolactobacillus (5\%).

Microrganismos produtores de ácido lático têm sido detectados em reatores operados para produção de hidrogênio, mas sua função ainda não é bem entendida, podendo influenciar negativamente, positivamente e até mesmo produzir hidrogênio (SIKORA et al. 2013). Relacionando as sequencias detectadas com a produção de hidrogênio, observa-se que o aumento de COV não provocou mudança na estrutura da comunidade microbiana e nem na produção de hidrogênio. Microrganismos produtores de hidrogênio do Filo Firmicutes, Classe Clostridia, principalmente de três gêneros Clostridium strictu sensu, Thermohydrogenium, Thermoanaerobacterium foram selecionados desde o início da operação e permaneceram até o fim, em detrimento dos produtores de ácido lático que estavam presentes majoritariamente no inóculo.

No reator acidogênico R2 (USBR2), o inóculo, lodo de reator UASB tratando vinhaça da cana-de-açúcar, não apresentou predominância de um único Filo como ocorreu em USBR1, 
94

mas sim a presença de três Filos. Resultado este esperado, uma vez que foram inóculos diferentes. Os Filos Firmicutes e Proteobacteria com frequência de 38\% cada seguido de Bacterioidetes (23\%). No Filo Firmicutes foram detectadas sequencias relacionadas a microrganismos produtores de hidrogênio da Classe Clostridia, gêneros Thermoanaerobacterium (15\%), Thermohydrogenium (9\%) e Clostridium sensu stricto (3\%), bem como em menor frequência da Classe Bacilli Lactobacillus $(1,6 \%)$ e os aeróbios formadores de esporos dos gêneros Tumebacillus (9\%) e Alicyclobacillus (5\%). Os Filos Proteobacteria e Bacterioidetes foram compostos basicamente por sequencias relacionadas a Enterobacter (22\%), microrganismo produtor de hidrogênio (KAPIDAN e KARGI, 2006) e Wautersiella (28\%), respectivamente.

Microrganismos isolados pertencentes ao gênero Wautersiella são aeróbios não sendo encontrado na literatura espécies com capacidade fermentativa. Na etapa I, com COV de 30 gDQO. $\operatorname{Lr}^{-1} \cdot$ dia $^{-1}$, houve seleção do Filo Firmicutes (95\%) com sequencias relacionadas produtores de hidrogênio da Classe Clostridia, gênero Clostridium sensu stricto (21\%) bem como da classe Bacilli, gêneros Lactobacillus (53\%), Leuconostoc (8,5\%) e Sporolactobacillus (6\%). Interessante notar a seleção de microrganismos produtores de ácido lático em detrimento dos conhecidos produtores de hidrogênio, tais microrganismos têm sido detectados em reatores operados para produção de hidrogênio, mas sua função ainda não é bem entendida, principalmente em ambientes termofílicos, podendo influenciar negativamente, positivamente e até mesmo produzir hidrogênio (SIKORA et al. 2013).

No final da COV de 60gDQO. $\mathrm{Lr}^{-1} \cdot \mathrm{dia}^{-1}$, houve seleção e aparecimento de novos filos. A frequência de sequencias relacionadas ao Filo Firmicutes foi de $29 \%$, inferior à carga anterior. Sequencias relacionadas aos filos Proteobacteria e Bacterioidetes foram de $40 \%$ e 17\%, respectivamente, e novos filos surgiram tais como Thermotogae (3\%), Actinobacteria (3\%), Synergistestes $(2 \%)$.

A Figura 20 demonstra que o Filo Firmicutes foram detectadas sequencias relacionadas a sequencias detectadas na etapa I, tais como Lactobacillus (2\%), Clostridium sensu stricto (1\%), Thermohydrogenium, Thermoanaerobacterium e Leuconostoc com frequência menor que $1 \%$. Novas sequencias foram detectadas e pertencentes microrganismos fermentadores dos gêneros Trichococcus (5\%), Proteiniclasticum (6,8\%), Desemzia (6,4\%). Para o Filo Proteobacteria sequencias relacionadas a Pseudomonas prevaleceram (21\%), espécies deste gênero são capazes de produzir hidrogênio (KAPDAN e KARGI, 2006) seguida de Arcobacter $(8,5 \%)$ gênero que contem espécies metabolicamente diversas (ROALKVMAN et al., 2015). 


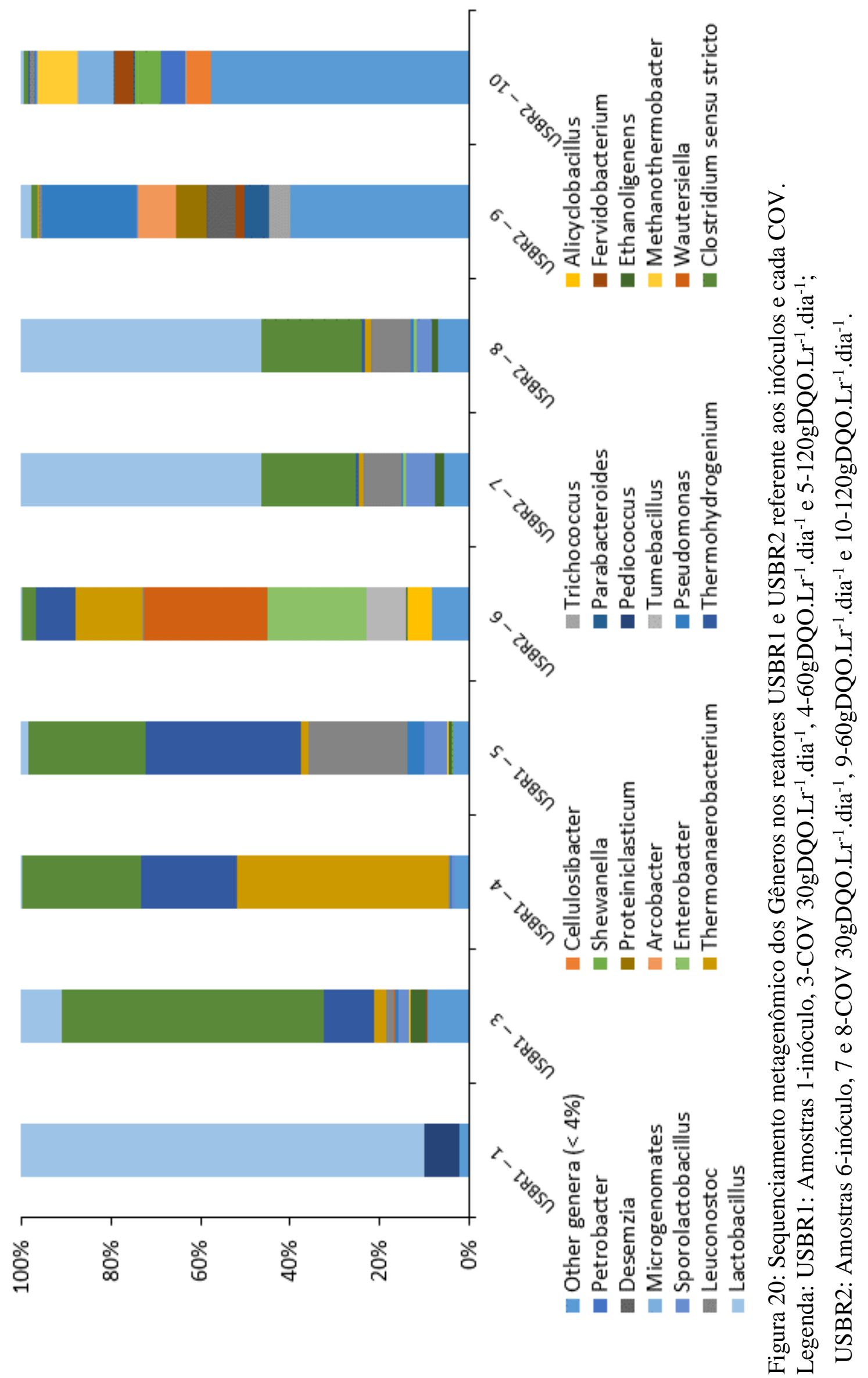


Bacterioidetes foram representadas por sequencias relacionadas ao gênero Parabacteroides (6\%) que apresenta espécies fermentadoras de carboidratos (TAN et al., 2012). Na etapa III, COV 120gDQO.Lr ${ }^{-1} \cdot \mathrm{dia}^{-1}$, o Filo Firmicutes voltou a predominar com frequência de $42 \%$, seguido de Proteobacteria (18\%). Interessante notar o aparecimento de vários novos Filos com frequência inferior a $6 \%$ mostrados na Figura 19. Interessante notar também a detecção de sequencias no Filos Firmicutes e Proteobacteria em menor frequência quando comparado as etapas anteriores.

Por exemplo, foram detectadas sequencias relacionadas a bactérias láticas tais como Lactobacillus (0,5\%), Leuconostoc (0,7\%), Sporolactobacillus (0,2\%) e Trichococcus $(0,3 \%)$. Da ordem Clostridiales foram detectadas sequencias relacionadas a produtores de hidrogênio Clostridium sensu stricto (1\%), Thermohydrogenium, Thermoanaerobacterium com frequência de $0,2 \%$ e Cellulosibacter (5,1\%). Em Proteobacteria foram detectadas sequencias relacionadas aos gêneros com capacidade metabólica de produção de hidrogênio tais como Pseudomonas $(0,3 \%)$, Enterobacter $(0,2 \%)$ e fermentadoras Shewanella $(5,4 \%)$ e Petrobacter $(5,4 \%)$. Para outros filos foram detectadas sequencias relacionadas a microrganismo produtor de hidrogênio Fervidobacterium $(4,2 \%)$ do Filo Thermotogae.

\subsubsection{Conclusões Parciais Sobre Análise Comparativa dos Reatores Acidogênicos}

A geração de ácidos orgânicos foi relativamente maior em R2 que em R1, sendo que para R2, o butirato e acetato foram os metabólitos predominantes. Em contrapartida, em R1 o metabólito predominante foi o ácido propiônico, inibindo a produção de hidrogênio desviando a rota metabólica para o consumo de $\mathrm{H}_{2}$.

Também em R2 se verifica conversão de carboidratos em torno de $65 \%$, bem acima da porcentagem de R1 com $40 \%$ de eficiência de conversão.

Os dados expostos acima sustentam a maior produtividade de hidrogênio em R2 em $88 \%$ maior, comparado a R1.

A análise biomolecular do DGGE apontou que o aumento de COV influenciou a composição da comunidade microbiana no reator, quanto maiores os índices de diversidade (H), menores índices de dominância (D) para as maiores cargas volumétricas. 
Pelos resultados do sequenciamento metagenômico em ambos os biorreatores ocorreu a redundância funcional com a seleção de sequencias de microrganismos fermentadores do Filos Firmicutes, Proteobacteria e Bacterioidetes, envolvidos direta e indiretamente na produção de hidrogênio. Em R2 (USBR2) a diversidade de Filos e gêneros fermentadores e produtores de hidrogênio foi superior a R1 (USBR1), com detecção também de Thermotogae, Actinobacteria, Chloroflexi, Synergistetes, o que pode explicar a maior produção de hidrogênio neste biorreator mesmo com o aumento da COV aplicada.

Os resultados mostram também que tanto a fonte do inóculo quanto o meio suporte influenciaram na seleção da microbiota e, portanto, na produção de hidrogênio. Lodo de reator UASB e espuma de poliuretana (USBR2) foram mais adequados na seleção de microbiota diversa envolvida direta e indiretamente na produção de hidrogênio que vinhaça autofermentada e pelo polietileno de baixa densidade.

$\mathrm{Na}$ conclusão parcial, sob as condições termofílicas $\left(55^{\circ} \mathrm{C}\right)$ e operacionais impostas neste estudo, o reator R2 inoculado com lodo de reator UASB e usando como material suporte a espuma de poliuretano, demonstrou melhor desempenho na geração de metabólitos associados a via acidogênica, com aumento de aproximadamente $80 \%$ na produção de hidrogênio, comparado ao reator 1 , inoculado com vinhaça auto fermentada e como material suporte o polietileno de baixa densidade.

De acordo com o exposto acima optou-se por manter o reator 2 em operação por longo período de tempo, compondo o sistema acidogênico/metanogênico. 
98

\subsection{Etapa 2 - Análise do Sistema de Reatores Combinados}

Os dados apresentados nesta etapa foram analisados com abordagem descritiva do desempenho dos reatores acidogênico e metanogênico em série. Foi dada ênfase nas características individuais de cada reator em relação aos bioprocessos envolvidos, suas comunidades microbianas estabelecidas, geração de ácidos orgânicos intermediários de interesse e eficiência de geração de biogás na acidogênese $\left(\mathrm{H}_{2}\right)$ e metanogênese $\left(\mathrm{CH}_{4}\right)$.

\subsubsection{Análise do Desempenho do Reator Acidogênico}

De acordo com a análise dos dados obtidos na etapa anterior, optou-se por utilizar o reator acidogênico R2 descrito anteriormente (inoculado com lodo de reator UASB e espuma de poliuretano como material suporte), para acoplar o Reator Metanogênico em série. Na associação em série, esse reator passou a ser denominado Reator Acidogênico. O bioprocesso foi avaliado em relação a produção global de hidrogênio por meio de análises das variáveis aplicadas, validação dos dados obtidos por métodos estatísticos e análise comparativa dos resultados com a literatura pertinente.

O reator foi operado por 417 dias consecutivos em condição termofílica de $55^{\circ} \mathrm{C}$, com TDH fixo de 2 horas, com DQO de 2,5 g. $\mathrm{L}^{-1}$ ( $1^{\circ}$ ao $12^{\circ}$ dias), 5 g. $\mathrm{L}^{-1}$ ( $13^{\circ}$ ao $26^{\circ}$ dias) e 10 g.L $\mathrm{L}^{-1}\left(27^{\circ}\right.$ ao $417^{\circ}$ dias), que corresponde a COV de 30, 60 e 120 gDQO.Lreator ${ }^{-1}$.dia ${ }^{-1}$, respectivamente. No entanto como os dados do $1^{\circ}$ ao $45^{\circ}$ dias de operação já foram discutidos na Etapa anterior, optou-se por apresentar os dados relativos a operação de 372 dias consecutivos $\left(45^{\circ}\right.$ ao $417^{\circ}$ dias) com carga fixa de DQO de 10 g. $\mathrm{L}^{-1}$ que corresponde a COV de $120 \mathrm{gDQO} \cdot$ Lreator $^{-1} \cdot \mathrm{dia}^{-1}$.

Os valores de COV obtidos no afluente (Figura 21a) foram em média de 119,29 $\pm 9,12$ gDQO.Lreator ${ }^{-1} \cdot$ dia $^{-1}$ (138 e 96 gDQO.Lr ${ }^{-1} \cdot$ dia $^{-1}$, máximo e mínimo respectivamente).

Nota-se que o valor médio na análise estatística de boxplot apresentado na Figura $21 \mathrm{~b}$ ficou bem próximo ao valor teórico proposto. 

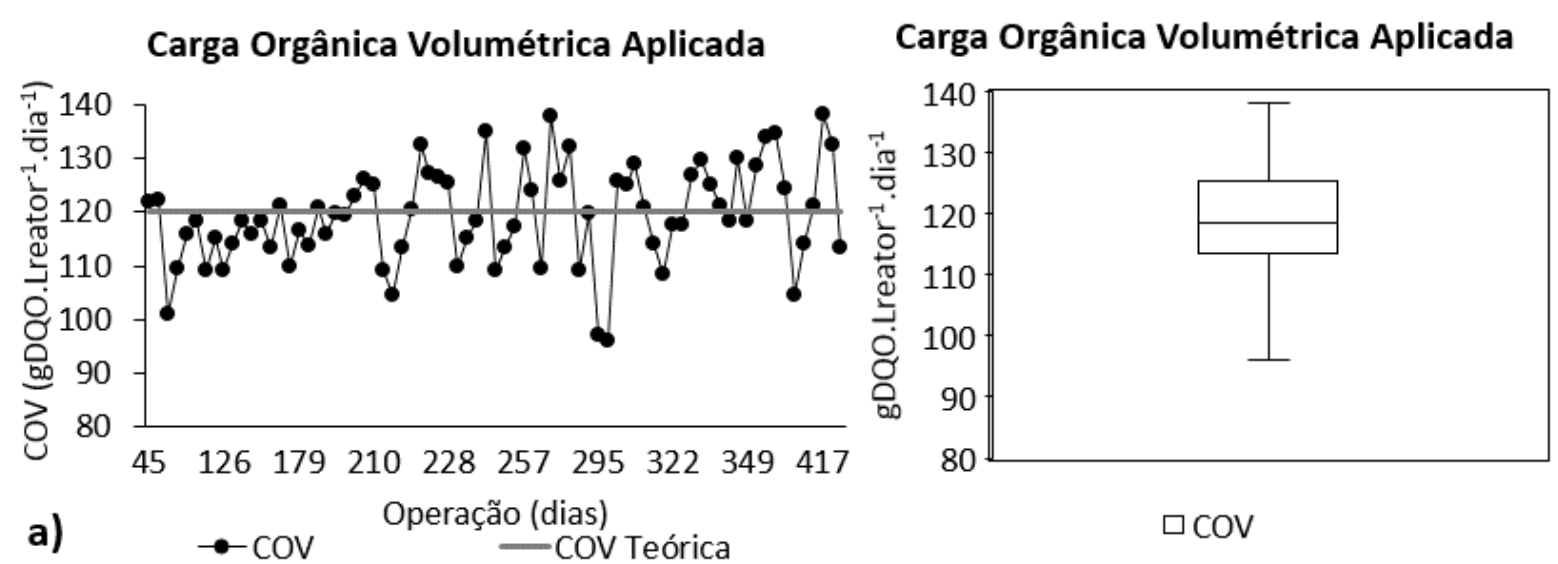

Figura 21: Monitoramento da carga orgânica volumétrica aplicada (COV) ao reator acidogênico; a) Monitoramento temporal da COV, b) Análise estatística de boxplot da variação da $\mathrm{COV}$.

A oscilação do $\mathrm{pH}$ afluente verificada na Figura 22a esteve associada às variações composicionais do melaço e por não haver suplementação de álcali, o que impossibilita a manutenção do $\mathrm{pH}$ afluente fixo. O valor médio do $\mathrm{pH}$ de entrada foi de 5,32 $\pm 0,42$, com valores máximo e mínimo de 6,54 e 4,45, respectivamente, e os valores obtidos no efluente foi média de 4,16 $\pm 0,31$, com valores máximo e mínimo de 4,88 e 3,37, respectivamente (Figura 22b).
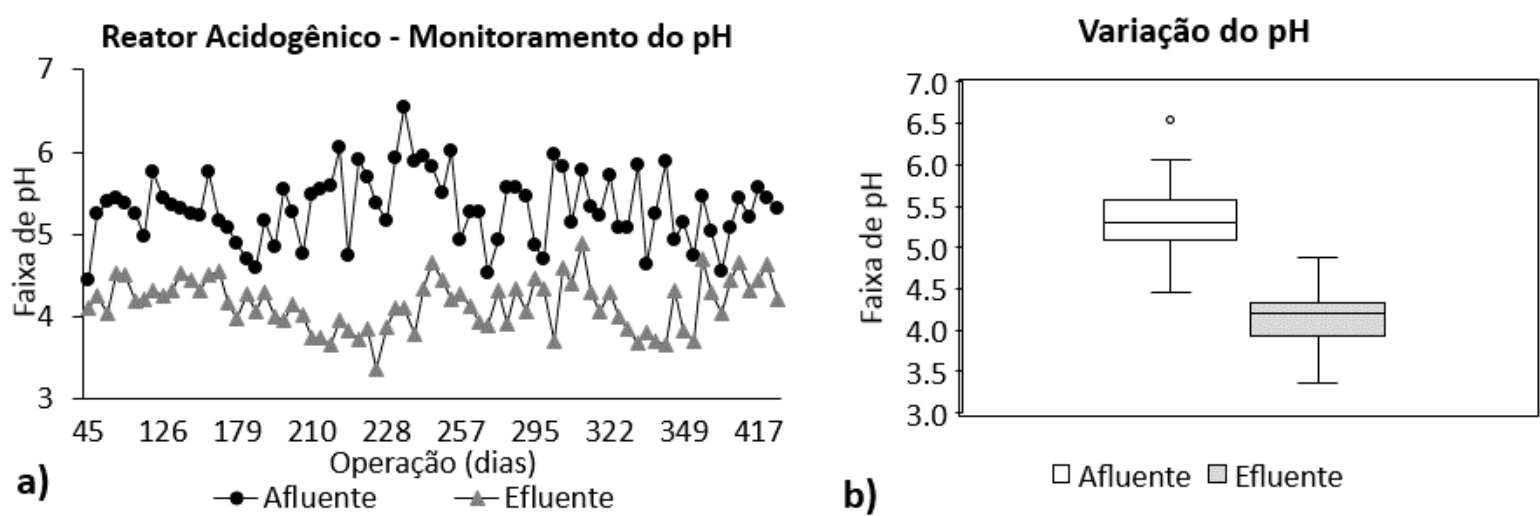

Figura 22: Monitoramento do $\mathrm{pH}$; a) Variação temporal do $\mathrm{pH}$ afluente e efluente, b) Análise estatística de boxplot da variação de $\mathrm{pH}$.

Observa-se a acidificação no reator, com valores indicativos de sistemas fermentativos acidogênicos. Conforme relata Temudo et al. (2008), as faixas de $\mathrm{pH}$ abaixo da neutralidade impõem uma forte pressão de seleção no sistema, favorecendo bactérias produtoras de hidrogênio, por exemplo espécies dos gêneros Clostridium spp e Bacillus spp, as quais desenvolvem endósporos em condições ambientais adversas, o que contribui para a sua resistência natural. 
A geração de ácidos totais no efluente reforçam a afirmação que a acidogênese ocorreu ao longo de todo o período operacional (Figura 23a). O valor médio da geração de ácidos orgânicos totais no efluente foi de $602 \pm 171 \mathrm{mg} . \mathrm{L}^{-1}$, com valores mínimos e máximos de 313 a $1030 \mathrm{mg} . \mathrm{L}^{-1}$, respectivamente (Figura 23b).
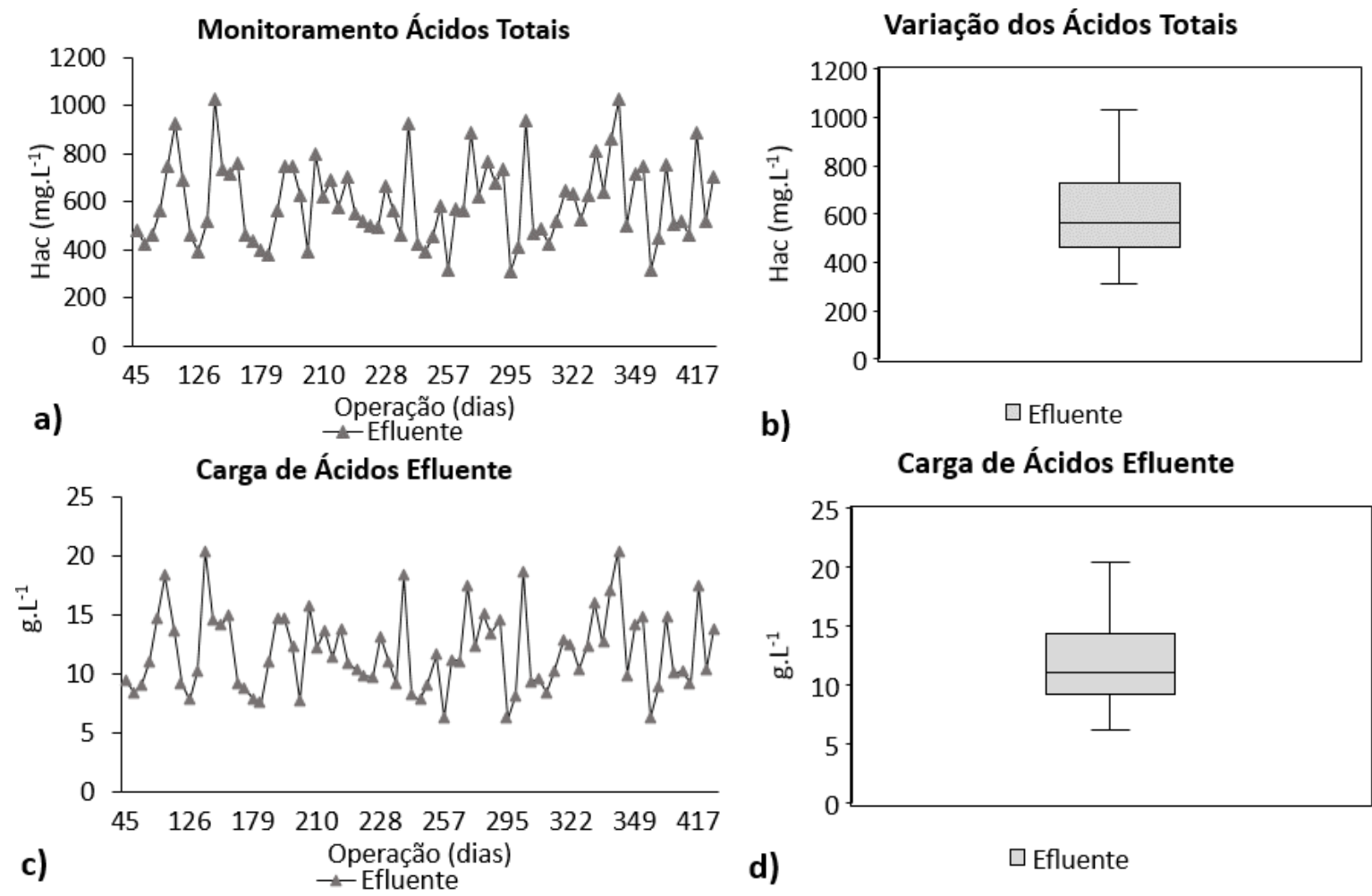

b)

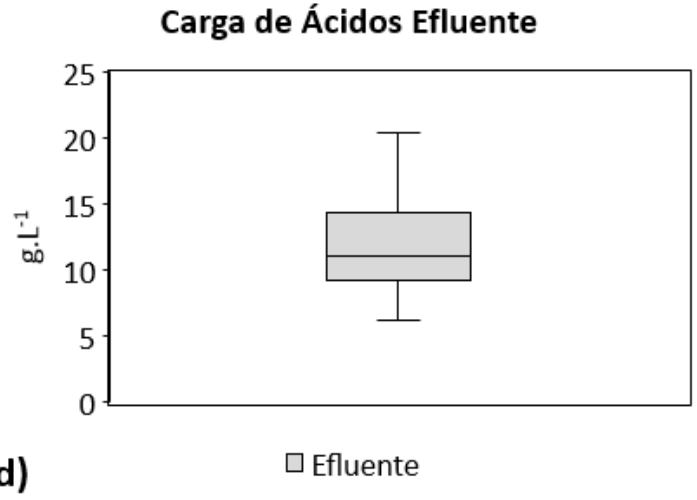

Figura 23: Monitoramento da geração de ácidos totais; a) Variação temporal da geração de ácidos totais, b) Análise estatística de boxplot da geração de ácidos totais, c) Carga de ácidos no efluente, d) Análise estatística de boxplot da carga de ácidos no efluente

Segundo Deublein e Steinhauser (2010), o acúmulo de ácidos orgânicos nos sistemas fermentativos, favorece as bactérias produtoras de hidrogênio, pois inibem os organismos metanogênicos. McCarty e McKinney (1961) ainda relatam que ela é intensificada pelo pH, sendo que quanto maior a concentração de ácidos orgânicos e menor valores de $\mathrm{pH}$, maior será o efeito da inibição na metanogênese.

Conforme observado nos dados apresentados, houve sucesso na operação do reator, com manutenção da acidogênese por longo período de tempo. A hipótese levantada para a manutenção de acidificação prolongada, foi que a estratégia da manutenção da alta carga orgânica afluente, pela elevada vazão e consequente baixo valor de TDH. 
A matéria orgânica afluente expressa em DQO manteve-se entre 8,01 a 11,51 g.L $\mathrm{L}^{-1}$, com DQO efluente variando entre 7,47 a 11,20 g.L $\mathrm{L}^{-1}$. A eficiência de remoção de DQO variou de $1,06 \%$ e 18,28\%, valor mínimo e máximo respectivamente (Figura 24a).

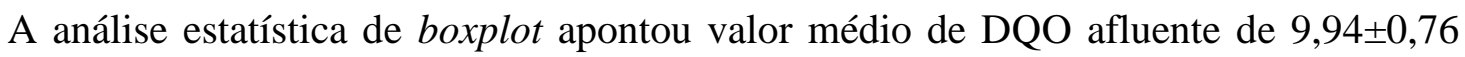
g. $\mathrm{L}^{-1}$, bem próximos ao teórico planejado $\left(10 \mathrm{~g} . \mathrm{L}^{-1}\right)$. A DQO efluente obteve valor médio de $9,20 \pm 0,73$ g.L ${ }^{-1}$.

A DQO removida ficou com valor médio de $0,74 \pm 0,46$ g.L -1 $^{-1}$ (Figura 24b).

A porcentagem de eficiência de remoção de DQO obteve valor médio de 7,39\% $\pm 4,30 \%$, manteve-se na faixa reportada na literatura para condições acidogênicas (5-30\% de eficiência), conforme aponta a análise estatística de boxplot (Figura 24c).
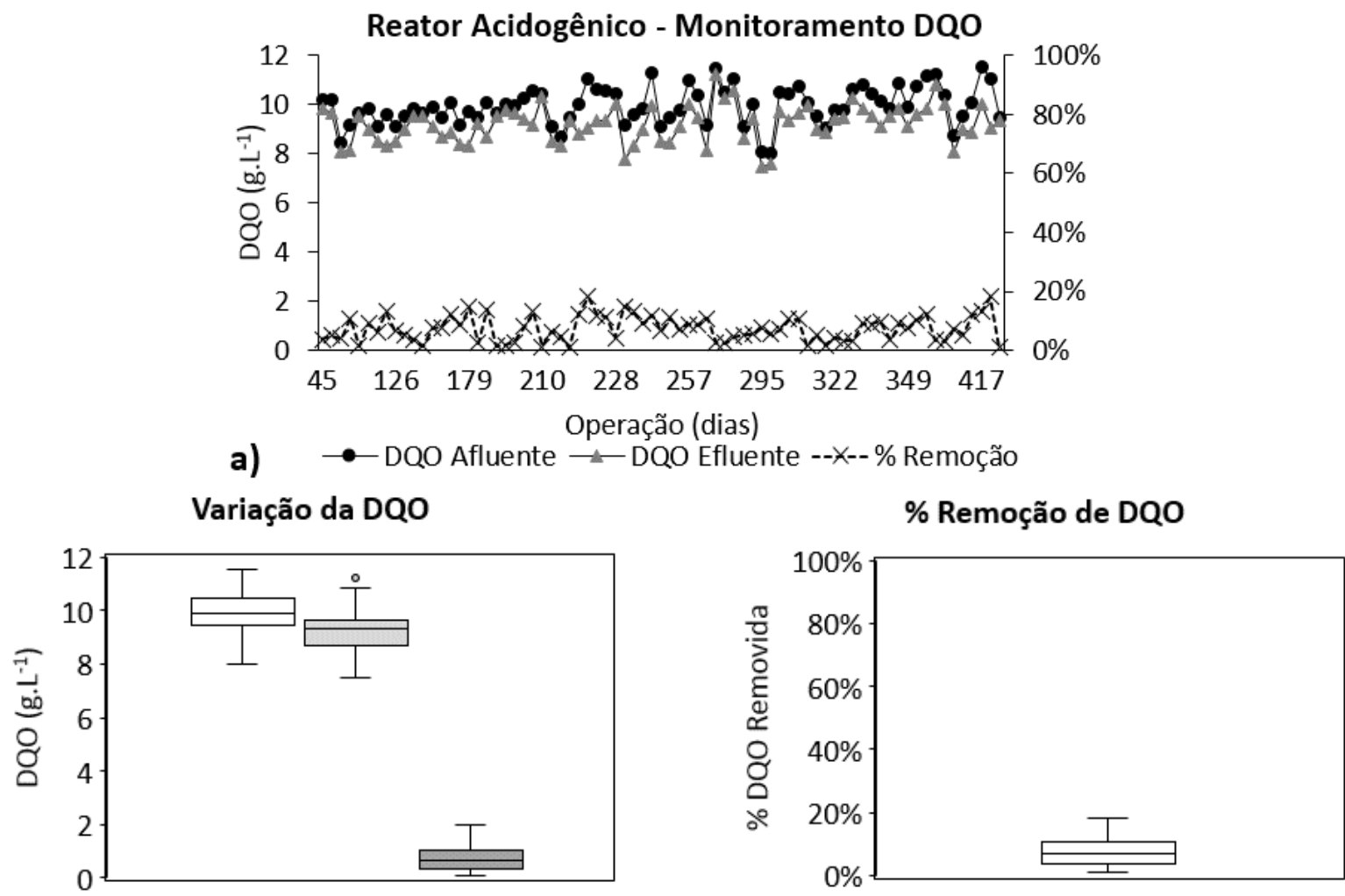

b)

$\square$ Afluente $\square$ Efluente $\square$ Removida

c)

$\square \%$ Remoção

Figura 24: Monitoramento da remoção de DQO reator acidogênico; a) Monitoramento temporal da remoção de DQO, b) Análise estatística de boxplot da variação da DQO, c) Análise estatística de boxplot da porcentagem de remoção de DQO.

A remoção de DQO relatada no presente estudo foi associada à manutenção celular do reator devido ao baixo TDH aplicado. Destaca-se que não foi realizado descarte da biomassa 
durante o período operacional e que o controle da biomassa foi realizado pela perda parcial no efluente, permitindo a constante renovação da biomassa no reator.

O acúmulo de biomassa está associado a efeitos negativos sobre a produção continua de hidrogênio, conforme descrevem Hafez et al. (2010), Peixoto et al. (2011) e Anzola-Rojas et al. (2015). Os autores citados apontam que a carga orgânica específica é determinante para a manutenção do processo, sem o desenvolvimento de rota de digestão complementar.

A concentração de carboidratos afluente apresentou valores entre 3,48 a 6,33 g.L $\mathrm{L}^{-1}$ e a concentração de carboidrato efluente variou entre 1,75 a 3,59 g.L.-1. A eficiência de conversão de carboidrato ficou com porcentagem variando de 24,12\% a 61,65\% (Figura 25a).

A análise estatística de boxplot para a concentração de carboidratos apontou valores no

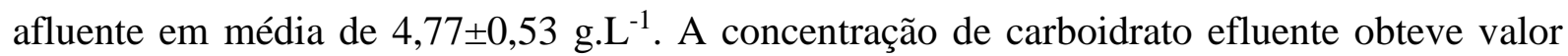

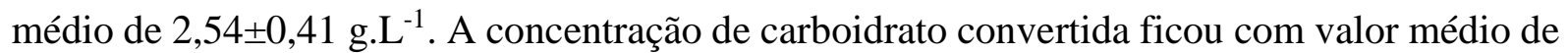
2,22 $\pm 0,48$ g.L.- (Figura 25b).

Conforme aponta a análise estatística de boxplot a porcentagem de conversão de carboidratos totais foi em média de 46,42 $\pm 0,48 \%$ (Figura 25 c).

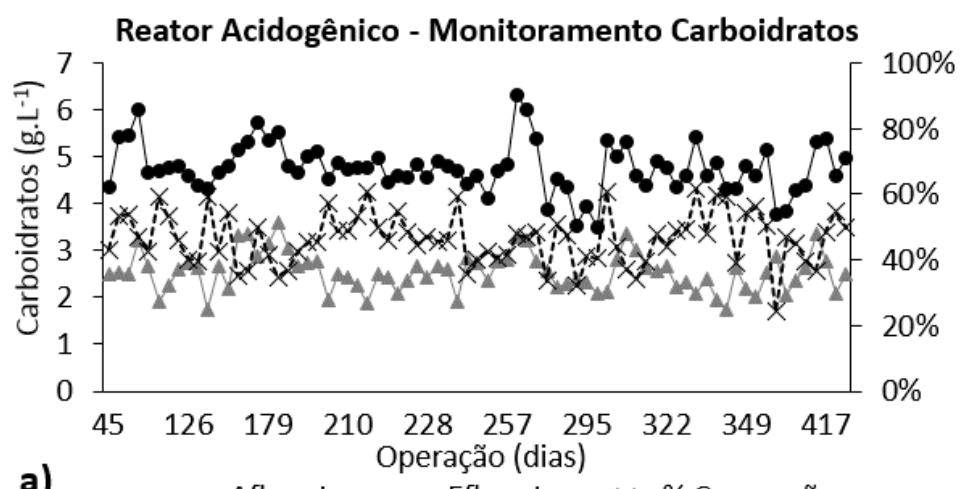

Variação de Carboidratos

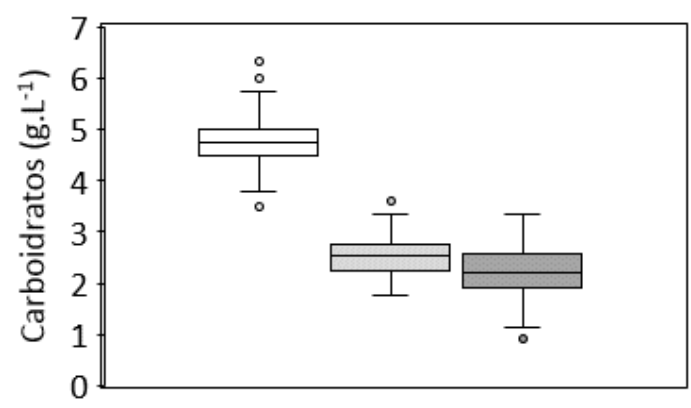

b) $\square$ Afluente $\square$ Efluente $\square$ Convertido
\% Conversão de Carboidratos

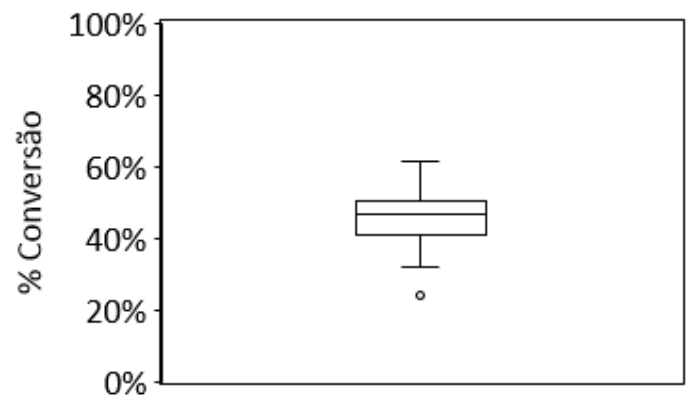

c)

Figura 25: Monitoramento da conversão de carboidratos reator acidogênico; a) Monitoramento temporal da conversão de carboidratos, b) Análise estatística de boxplot da variação dos carboidratos, c) Análise estatística de boxplot da porcentagem de conversão de carboidratos. 
O valor médio reportado neste trabalho ficou abaixo do que relatados por Braga et al. (2015) com média de 63\% de eficiência de conversão de carboidratos. Os autores operaram um reator do tipo UASB (TDH 6-12h) alimentado com efluente sintético a base de sacarose sob condições termofílicas $\left(55^{\circ} \mathrm{C}\right)$ para a produção continua de hidrogênio. Ferraz (2015) relatou eficiência de conversão acima de 60\%, com TDH de 10 horas para vinhaça com médias de conversão de carboidratos de 67 a 79\% em estudo para produção de $\mathrm{H}_{2}$ em reatores UASB.

Os valores inferiores de conversão de carboidratos relatados no trabalho, podem estar associados à estratégia de baixo TDH $(2 \mathrm{~h})$, como consequência demonstra que o metabolismo das bactérias nas condições ambientais estabelecidas no reator pode ter direcionado o metabolismo para rotas menos eficientes de conversão de carboidratos. Entretanto, a estratégia permitiu manter o ambiente acidogênico.

Para melhor compreensão e comparativa dos dados acima expostos, na Tabela 15 é apresentada uma visão geral do monitoramento das variáveis avaliados no reator acidogênico.

Tabela 15: Resumo do monitoramento das variáveis do reator acidogênico

\begin{tabular}{|c|c|c|c|}
\hline \multicolumn{4}{|c|}{ Resumo do Monitoramento dos Parâmetros Físico Químico } \\
\hline \multirow{2}{*}{\multicolumn{2}{|c|}{ Parâmetro }} & \multicolumn{2}{|c|}{ Reator Acidogênico } \\
\hline & & Afluente & Efluente \\
\hline \multirow{4}{*}{$\mathrm{pH}$} & Média & 5,32 & 4,16 \\
\hline & Máximo & 6,54 & 4,88 \\
\hline & Mínimo & 4,45 & 3,37 \\
\hline & Desvio Padrão & $\pm 0,42$ & $\pm 0,31$ \\
\hline \multirow{4}{*}{ Ácidos Totais (mg. $\left.\mathrm{L}^{-1}\right)$} & Média & 244 & 602 \\
\hline & Máximo & 396 & 1030 \\
\hline & Mínimo & 151 & 313 \\
\hline & Desvio Padrão & \pm 50 & \pm 171 \\
\hline \multirow{4}{*}{ Carga de ácidos (gAGV.dia $\left.{ }^{-1}\right)$} & Média & - & 12 \\
\hline & Máximo & - & 20,40 \\
\hline & Mínimo & - & 6,20 \\
\hline & Desvio Padrão & - & $\pm 3,40$ \\
\hline \multirow{5}{*}{ DQO $10\left(\mathrm{~g} \cdot \mathrm{L}^{-1}\right)$} & Média & 9,94 & 9,20 \\
\hline & Máximo & 11,51 & 11,20 \\
\hline & Mínimo & 8,01 & 7,47 \\
\hline & Desvio Padrão & 0,76 & 0,73 \\
\hline & \% Média de Remoção & - & $7,39 \%$ \\
\hline \multirow{5}{*}{ Carboidratos Totais (g.L $\left.\mathrm{L}^{-1}\right)$} & Média & 4,77 & 2,54 \\
\hline & Máximo & 6,33 & 3,59 \\
\hline & Mínimo & 3,485 & 1,75 \\
\hline & Desvio Padrão & $\pm 0,53$ & $\pm 0,41$ \\
\hline & \% Média de Conversão & - & $46,42 \%$ \\
\hline
\end{tabular}


104

Alguns parâmetros estão intimamente relacionados à produção de hidrogênio, embora trabalhos apresentados na literatura indiquem diferentes valores para as variáveis relacionadas. Nos sistemas fermentativos há relatos de produções decrescentes/desprezíveis de $\mathrm{H}_{2}$ e queda abrupta na produção de biogás, como por exemplo, para valores de $\mathrm{pH}$ inferiores a 5,0 por longo período de tempo. Ferraz et al. (2014) relatou que as condições demasiadamente ácidas podem afetar a atividade das hidrogenases, principais enzimas atuantes na produção de hidrogênio causando o colapso do reator acidogênico. No entanto, para este estudo não foi observado este comportamento. Conforme se verifica na Figura 26a, houve produção continua de biogás durante todo o período de operação do reator, com pico máximo de 11,46 e mínimo de 1,35 L.dia $^{-1}$ de biogás. A análise estatística de boxplot (Figura 26b) aponta pequenos pontos de oscilações e queda na produção de biogás (outliers), com produção de biogás em média de $6,69 \pm 2,26 \mathrm{~L} \cdot \mathrm{dia}^{-1}$.
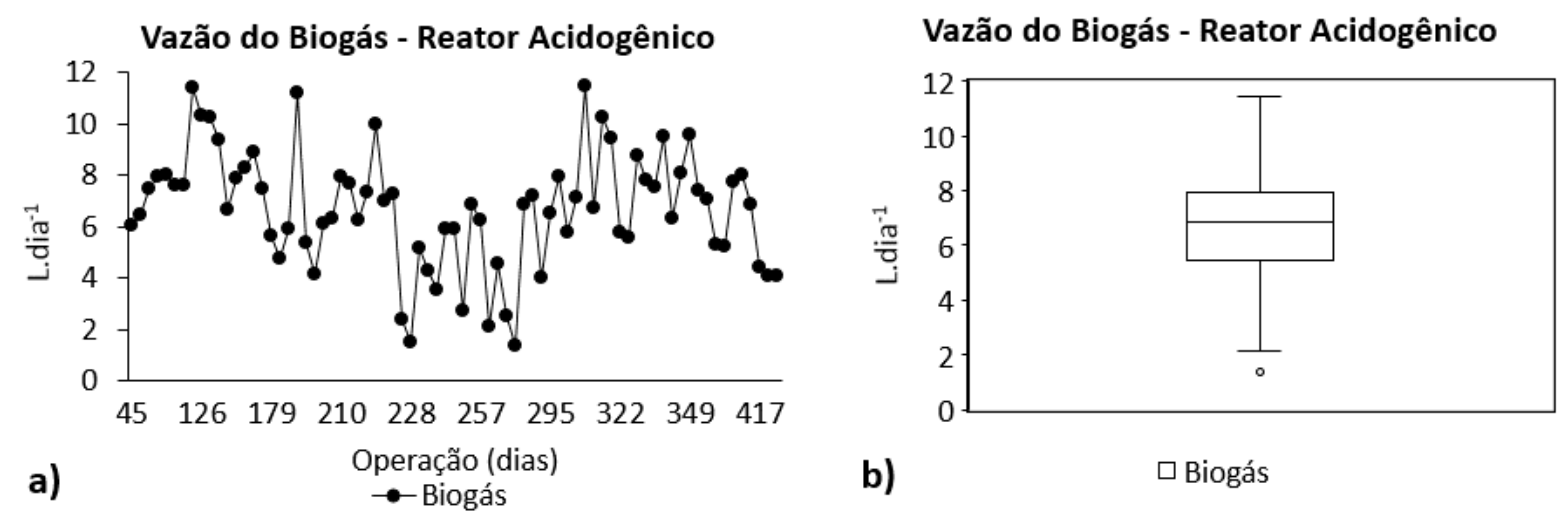

Figura 26: Monitoramento da vazão do biogás gerado; a) Variação temporal da produção de biogás, b) Análise estatística de boxplot da porcentagem da geração de biogás.

A composição do biogás apresentado na Figura 27a, aponta a presença de $\mathrm{H}_{2}$ no biogás ao longo de todo o período operacional. A composição do biogás apresentou média de $55,39 \pm 11,74 \%$ de hidrogênio, com valores máximo de 78,09\% e mínimo de 19,04\%. Como pode ser observado na análise estatística de boxplot (Figura 27 b) houve pontos discrepantes de porcentagem mínima para $\mathrm{H}_{2}$ e consequentemente pontos de máximo para a porcentagem de $\mathrm{CO}_{2}$. O gás carbônico ficou com média de 44,61+12\% (80,96\% e 21,91\%, máximo e mínimo respectivamente).

A Tabela 16 apresenta as porcentagens obtidas de cada gás avaliado. 


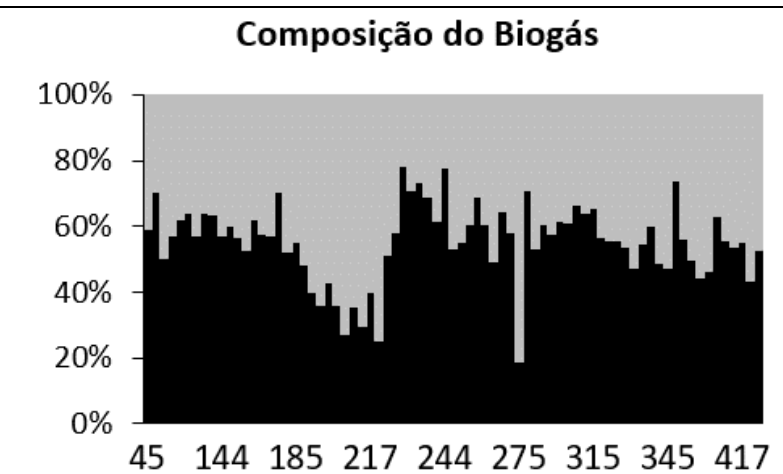

a)

$\mathbf{\mathrm { H }} 2 \square \mathrm{CO} 2$

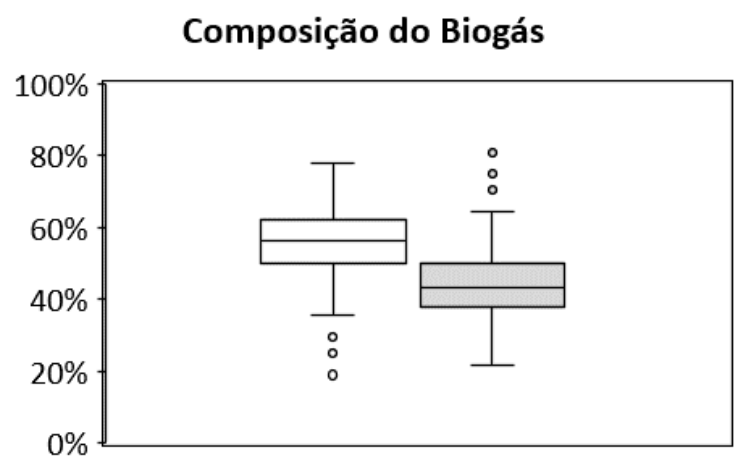

b)

$\square \mathrm{H} 2 \square \mathrm{CO} 2$

Figura 27: Monitoramento da composição do Biogás; a) Variação temporal da porcentagem da composição do biogás, b) Análise estatística de boxplot da porcentagem da composição do biogás.

Tabela 16: Monitoramento e composição o biogás gerado ao longo do experimento

\begin{tabular}{clcc}
\hline \multicolumn{2}{c}{ Composição do Biogás no Reator Acidogênico } \\
\cline { 2 - 4 } Variáveis & \multicolumn{2}{c}{ Porcentagem do Biogás } \\
\cline { 2 - 4 } & Média & $\mathbf{H}_{\mathbf{2}}$ & $\mathbf{C O}_{\mathbf{2}}$ \\
\hline \multirow{3}{*}{ Reator Acidogênico } & $55 \%$ & $44 \%$ \\
& Máximo & $78 \%$ & $80 \%$ \\
& Mínimo & $19 \%$ & $21 \%$ \\
& Desvio Padrão & $\pm 11 \%$ & $\pm 11 \%$ \\
\hline
\end{tabular}

A porcentagem de $\mathrm{H}_{2}$ no biogás (55,39\%) ficou acima que o relatado por Ferraz (2013) operando reatores UASB em condições termofílicas $\left(55^{\circ} \mathrm{C}\right)$, que submeteu o reator ao aumento de COV. O autor citado relata que o reator atingiu valor de porcentagem média da composição de hidrogênio no biogás de $36,2 \pm 5,8 \%$.

Durante o período experimental, não foi observado metano na composição do biogás, indicando que as estratégias aplicadas, especialmente as condições operacionais impostas de temperatura $\left(55^{\circ} \mathrm{C}\right)$, TDH baixo $(2 \mathrm{~h})$ e COV fixa $\left(120 \mathrm{gDQO} \cdot \mathrm{Lr}^{-1} \cdot \mathrm{d}^{-1}\right)$ apresentaram forte influência na produção continua de hidrogênio e inibição da metanogênese.

Segundo a literatura pertinente sobre a abordagem da produção de hidrogênio, vários autores relatam que apesar do crescente interesse na produção biológica de $\mathrm{H}_{2}$, ainda não há uma padronização nas unidades das variáveis, dificultando a comparação dos dados obtidos com as peculiaridades de cada trabalho realizado.

Sendo assim optou por apresentar os dados para a Produção Bruta de Hidrogênio $\left(\mathrm{PBH}_{2}\right)$ na forma de $\mathrm{LH}_{2} \cdot \operatorname{dia}^{-1}$ (Litros de hidrogênio produzidos por dia). Para a Produção Volumétrica de Hidrogênio $\left(\mathrm{PVH}_{2}\right)$ optou-se pela notação dos dados em $\mathrm{LH}_{2}$. Lreator $^{-1}$.dia ${ }^{-1}$ (Litros de hidrogênio produzidos por litro de reator por dia). 
A produção de hidrogênio foi continua em todos os dias de operação do reator acidogênico. $\mathrm{O}$ valor médio obtido na produção bruta de hidrogênio $\left(\mathrm{PBH}_{2}\right)$ foi de 3,69 $\pm 1,53$ $\mathrm{LH}_{2} \cdot \mathrm{dia}^{-1}$, com pico de produção de 7,60 $\mathrm{LH}_{2} \cdot \mathrm{dia}^{-1}$, e valor mínimo de produção de 0,79 $\mathrm{LH}_{2} \cdot \mathrm{dia}^{-1}$ (Figura 28a). A análise estatística de boxplot demonstrou que não houve produções discrepantes (outliers), no entanto o gráfico apontou variação nos resultados de produção, possivelmente ocasionada por desvio de rotas metabólicas, seja para o crescimento celular ou devido aos ácidos orgânicos gerados para produção de hidrogênio (acético e butírico) e consumo (propiônico).

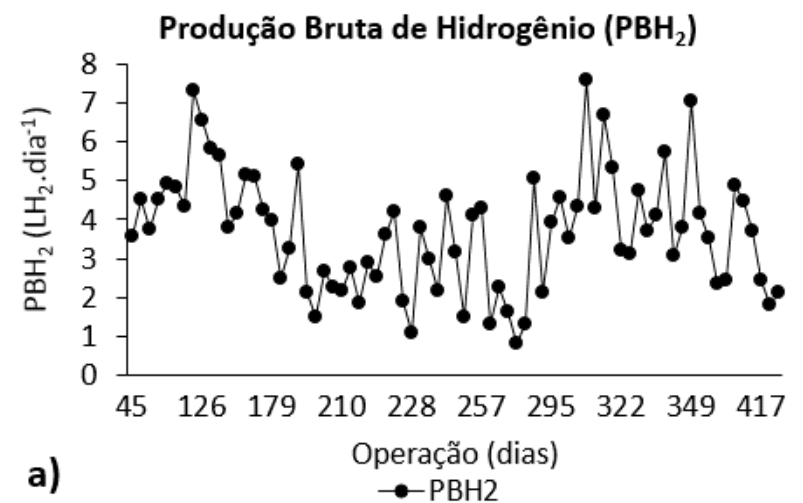

Figura 28: Monitoramento da produção de hidrogênio; a) Variação temporal da produção bruta de hidrogênio $\left(\mathrm{PBH}_{2}\right)$, b) Análise estatística de boxplot da produção bruta de hidrogênio $\left(\mathrm{PBH}_{2}\right)$.

Os gráficos da produção volumétrica de hidrogênio $\left(\mathrm{PVH}_{2}\right)$ apresentados na Figura $29 \mathrm{a}$ (variação temporal) e Figura 29b (análise estatística de boxplot), assemelham ao de produção

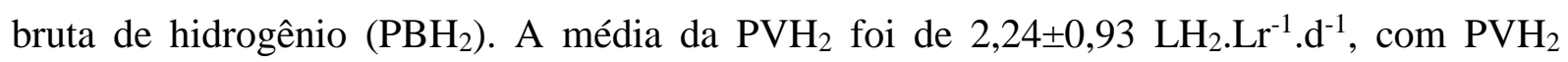
máxima de 4,61 e mínima de $0,48 \mathrm{LH}_{2} \cdot \mathrm{Lr}^{-1} \cdot \mathrm{d}^{-1}$. Visão comparativa do resumo das produções obtidas pode ser observada na Tabela 17.

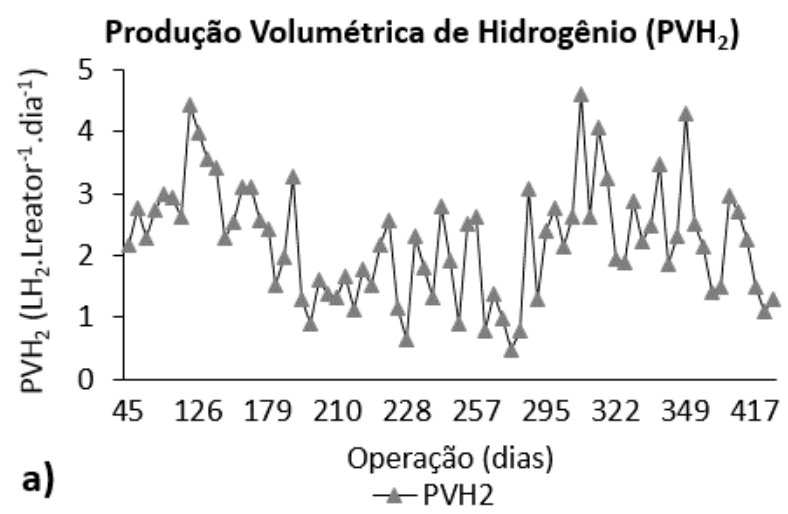

\section{Produção Volumétrica de Hidrogênio $\left(\mathrm{PVH}_{2}\right)$}

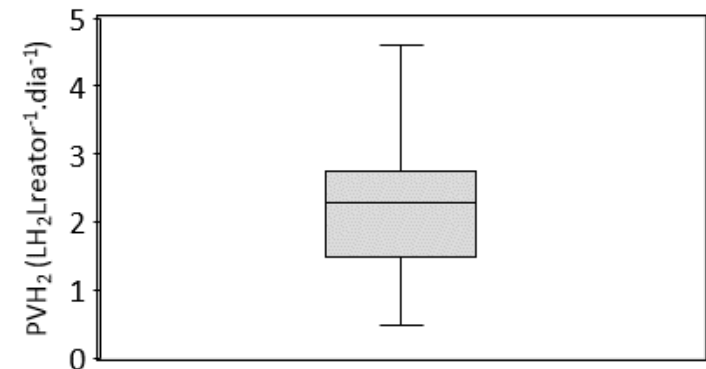

b)

$\square \mathrm{PVH} 2$

Figura 29: Monitoramento da produção de hidrogênio; a) Variação temporal da produção volumétrica de hidrogênio $\left(\mathrm{PVH}_{2}\right)$, b) Análise estatística de boxplot da produção volumétrica de hidrogênio $\left(\mathrm{PVH}_{2}\right)$. 
Tabela 17: Resumo das produções de hidrogênio $\left(\mathrm{PBH}_{2}\right.$ e $\left.\mathrm{PVH}_{2}\right)$

\begin{tabular}{|c|c|c|c|}
\hline \multicolumn{4}{|c|}{ Resumo das Produções de Hidrogênio } \\
\hline \multirow{2}{*}{\multicolumn{2}{|c|}{ Variáveis }} & \multicolumn{2}{|c|}{$\begin{array}{l}\text { Produções de Hidrogênio } \\
\end{array}$} \\
\hline & & $\begin{array}{c}\text { Produção Bruta de } \mathrm{H}_{2} \\
\left.\text { (LH2.dia }{ }^{-1}\right)\end{array}$ & $\begin{array}{c}\text { Produção Volumétrica de } \mathrm{H}_{2} \\
\left.\text { (LH2.Lreator-1.dia }{ }^{-1}\right)\end{array}$ \\
\hline \multirow{4}{*}{$\begin{array}{l}\text { Reator } \\
\text { Acidogênico }\end{array}$} & Média & 3,69 & 2,24 \\
\hline & Máximo & 7,60 & 4,61 \\
\hline & Mínimo & 0,79 & 0,48 \\
\hline & Desvio Padrão & $\pm 1,53$ & $\pm 0,93$ \\
\hline
\end{tabular}

A Tabela 18 apresenta resumo de trabalhos realizados com objetivo da produção de hidrogênio, para comparação de resultados com trabalhos citados na literatura. Os autores relatados utilizaram diferentes variáveis para apresentar seus resultados, tais como tipo de reator, substratos, TDH para reatores sequenciais ou tempo de ciclo (TC) para reatores em batelada e suas respectivas produções de hidrogênio.

Tabela 18: Tabela comparativa de trabalhos realizados com objetivo de produção de $\mathrm{H}_{2}$

\begin{tabular}{|c|c|c|c|c|c|}
\hline \multicolumn{6}{|c|}{ Tabela Comparativa de Trabalhos Realizados com Objetivo da Produção de $\mathrm{H}_{2}$} \\
\hline Referências & $\begin{array}{l}\text { Tipo de } \\
\text { Reator } \\
\text { (Temp) }\end{array}$ & Substrato & $\begin{array}{c}\text { TDH*, } \\
\text { TC** } \\
\text { (h) }\end{array}$ & $\begin{array}{l}\text { Operação } \\
\text { (dias) }\end{array}$ & $\begin{array}{c}\text { Produção ou } \\
\text { Rendimento de } \mathrm{H}_{2}\end{array}$ \\
\hline $\begin{array}{l}\text { Kongjan et } \\
\text { al. (2010) }\end{array}$ & $\begin{array}{l}\text { UASB } \\
\left(55^{\circ} \mathrm{C}\right)\end{array}$ & $\begin{array}{c}\text { Palha de Trigo } \\
\text { Hidrolisada }\end{array}$ & $24^{*}$ & 35 & $\begin{array}{c}883 \\
\mathrm{mLH}_{2} \cdot \mathrm{L}^{-1} \cdot \mathrm{dia}^{-1}\end{array}$ \\
\hline $\begin{array}{l}\text { Wang et al. } \\
(2013)\end{array}$ & $\begin{array}{l}\text { CSTR } \\
\left(35^{\circ} \mathrm{C}\right)\end{array}$ & $\begin{array}{c}\text { Melaço de } \\
\text { cana-de-açúcar }\end{array}$ & $5^{*}$ & 150 & $\begin{array}{c}294,48 \\
\mathrm{mmolH}_{2} \cdot \mathrm{d}^{-1}\end{array}$ \\
\hline $\begin{array}{l}\text { Kongjan et } \\
\text { al. (2013) }\end{array}$ & $\begin{array}{l}\mathrm{UASB} \\
\left(55^{\circ} \mathrm{C}\right)\end{array}$ & $\begin{array}{l}\text { Melaço de } \\
\text { Beterraba }\end{array}$ & $16^{*}$ & 34 & $\begin{array}{c}5600 \\
\mathrm{mLH}_{2} \mathrm{~L}^{-1} \cdot \mathrm{dia}^{-1}\end{array}$ \\
\hline $\begin{array}{l}\text { Ferraz et al. } \\
\text { (2014) }\end{array}$ & $\begin{array}{l}\text { APBR } \\
\left(55^{\circ} \mathrm{C}\right)\end{array}$ & Vinhaça & $12 *$ & 30 & $\begin{array}{c}762,20 \\
\mathrm{mLH}_{2} \mathrm{~L}^{-1} \cdot \mathrm{dia}^{-1}\end{array}$ \\
\hline $\begin{array}{l}\text { Reis et al. } \\
(2015)\end{array}$ & $\begin{array}{l}\text { AFBR } \\
\left(22^{\circ} \mathrm{C}\right)\end{array}$ & $\begin{array}{l}\text { Vinhaça }(25 \%) \\
\text { Glicose }(75 \%)\end{array}$ & $6^{*}$ & 40 & $18,4 \mathrm{molH}_{2} . \mathrm{kgDQO}^{-1}$ \\
\hline $\begin{array}{l}\text { Braga et al. } \\
\text { (2015) }\end{array}$ & $\begin{array}{l}\mathrm{UASB} \\
\left(55^{\circ} \mathrm{C}\right)\end{array}$ & $\begin{array}{l}\text { Sacarose } \\
\text { Sintética }\end{array}$ & $2^{*}$ & 84 & $\begin{array}{c}1807,92 \\
\mathrm{mLH}_{2} \mathrm{~L}^{-1} \cdot \mathrm{dia}^{-1}\end{array}$ \\
\hline $\begin{array}{l}\text { Albanez } \\
(2015)\end{array}$ & $\begin{array}{c}\mathrm{AnSBBR} \\
\left(30^{\circ} \mathrm{C}\right)\end{array}$ & $\begin{array}{l}\text { Vinhaça }(67 \%) \\
\text { Melaço }(33 \%)\end{array}$ & $3 * *$ & 29 & $\begin{array}{c}6,2 \\
\mathrm{molH}_{2} \mathrm{kgDQO}^{-1}\end{array}$ \\
\hline $\begin{array}{l}\text { Cheng et al. } \\
\text { (2016) }\end{array}$ & $\begin{array}{c}\text { HFB } \\
\left(37^{\circ} \mathrm{C}\right)\end{array}$ & $\begin{array}{c}\text { Bagaço de } \\
\text { cana-de-açúcar }\end{array}$ & $4 * *$ & 2,5 & $\begin{array}{c}876,3 \\
\mathrm{mLH}_{2} \cdot \mathrm{L}^{-1} \cdot \mathrm{dia}^{-1}\end{array}$ \\
\hline Este Estudo & $\begin{array}{c}\text { AFSBR } \\
\left(55^{\circ} \mathrm{C}\right)\end{array}$ & $\begin{array}{c}\text { Melaço de } \\
\text { cana-de-açúcar }\end{array}$ & $2^{*}$ & 471 & $\begin{array}{c}2240 \\
\mathrm{mLH}_{2} \text { Lreator }^{-1} \cdot \text { dia }^{-1}\end{array}$ \\
\hline Este Estudo & $\begin{array}{c}\text { AFSBR } \\
\left(55^{\circ} \mathrm{C}\right) \\
\end{array}$ & $\begin{array}{c}\text { Melaço de } \\
\text { cana-de-açúcar }\end{array}$ & $2^{*}$ & 471 & $\begin{array}{c}3690 \\
\mathrm{mLH}_{2 .} \mathrm{L}^{-1} \cdot \mathrm{dia}^{-1} \\
\end{array}$ \\
\hline Este Estudo & $\begin{array}{l}\text { AFSBR } \\
\left(55^{\circ} \mathrm{C}\right)\end{array}$ & $\begin{array}{c}\text { Melaço de } \\
\text { cana-de-açúcar }\end{array}$ & $2^{*}$ & 471 & $\begin{array}{c}1520 \\
\mathrm{mLH}_{2} \mathrm{~L}^{-1} \mathrm{~mol} \mathrm{carbo}^{-1}\end{array}$ \\
\hline
\end{tabular}


Como relatado anteriormente, pode-se observar que devido as diferentes formas de apresentação dos resultados, se tornam difíceis as comparações exatas entre os trabalhos utilizados, visto as características estruturais e concepções de cada experimento.

Outra maneira de expressar e comparar os resultados seria pelas análises estatísticas de correlação entre a produção de hidrogênio e as variáveis analisadas.

Os gráficos de correlação (Figura 30a, b, c, d, e, f) apontaram que não houve correlação positiva $(P=1)$ ou proporcional ao aumento, nem correlação negativa $(P=-1)$ ou inversamente proporcional entre a produção continua de hidrogênio e as variáveis mensuradas, havendo portanto correlação nula $(P=0)$.

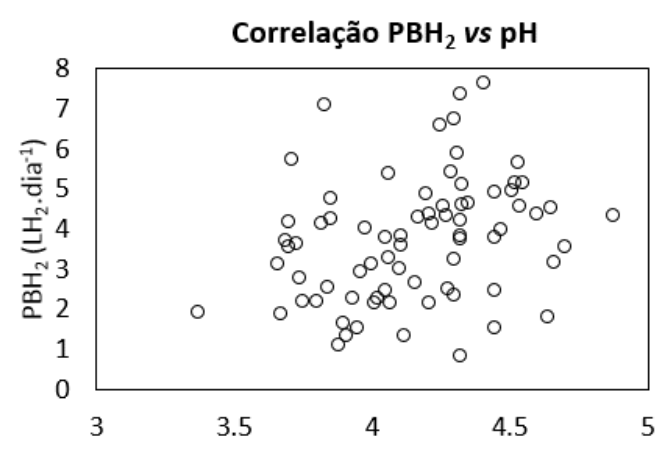

a)

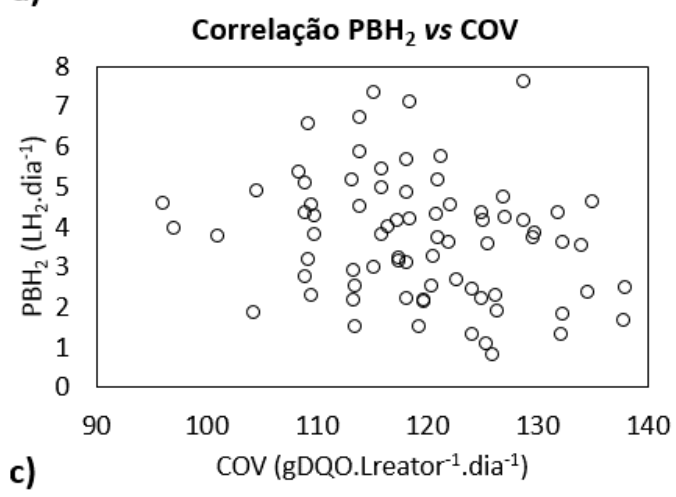

Correlação $\mathrm{PBH}_{2}$ vs COV Carboidratos

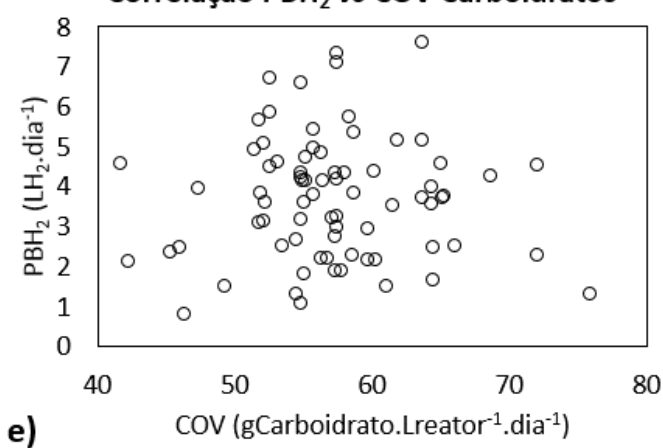

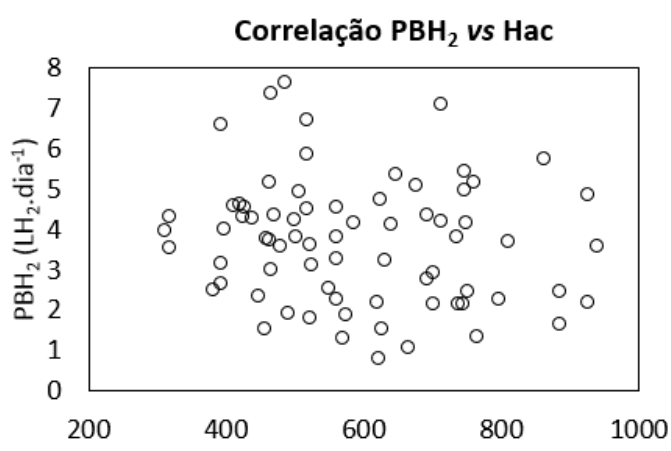

b) Ácidos Totais Hac $\left(\mathrm{mg} \cdot \mathrm{L}^{-1}\right)$
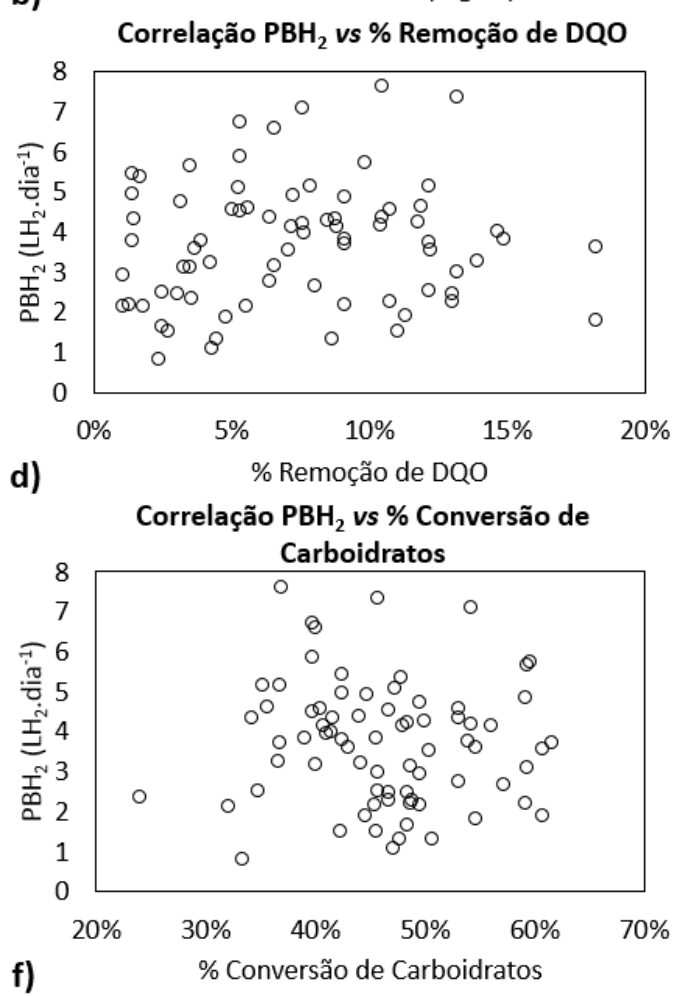

Figura 30: Análise estatística do coeficiente de correlação da produção bruta de hidrogênio $\left(\mathrm{PBH}_{2}\right)$; a) Correlação $\mathrm{PBH}_{2} v s \mathrm{pH}$, b) Correlação $\mathrm{PBH}_{2}$ vs ácidos totais, c) Correlação $\mathrm{PBH}_{2}$ vs $\mathrm{COV}$, d) Correlação $\mathrm{PBH}_{2}$ vs \% Remoção de DQO, e) Correlação $\mathrm{PBH}_{2}$ vs $\mathrm{COV}$ carboidratos, f) Correlação $\mathrm{PBH}_{2}$ vs \% conversão de carboidratos. 
Estes dados sustentam a hipótese que as estratégias adotadas de alta COV aliada ao TDH de 2 horas atuaram como fator limitante no crescimento da biomassa no reator e consequente renovação celular, essenciais para manutenção da produção de hidrogênio em reatores com alimentação continua. Por exemplo, observa-se no gráfico da Figura 30 a, que a produção bruta de hidrogênio ocorreu em uma faixa ampla de $\mathrm{pH}$ (entre 3,27 a 4,88).

Como exposto anteriormente, dados apontados na literatura sugerem que o $\mathrm{pH}$ tem um efeito mais significativo sobre a produção de hidrogênio, uma vez que afeta diretamente a atividade da hidrogenase, as vias metabólicas e as espécies dominantes. No entanto faixas de pH para a produção de hidrogênio podem ser bem amplas, devido a versatilidade dos microrganismos envolvidos (FANG et al, 2002, ANTONOPOULOU et al., 2010).

Em complementação ao observado, Kongjan et al. (2013) estudaram em condição termofílica $\left(55^{\circ} \mathrm{C}\right)$ a produção de hidrogênio e metano a partir do melaço de açúcar de beterraba em sistema de duas fases (UASB). Os autores relataram a produção média de hidrogênio de 4,3 $\mathrm{LH}_{2} \cdot \mathrm{Lr}^{-1} \cdot \mathrm{dia}^{-1}$, em faixa de $\mathrm{pH}$ média acima de 5. Os autores concluíram que o domínio das bactérias produtoras de hidrogênio no reator acidogênico, contribuíram para a manutenção da rota de produção de $\mathrm{H}_{2}$, demonstrando a versatilidade e adaptação dos organismos as condições termofílicas impostas.

Os resultados deste estudo apresentados na Tabela 19, interpreta-se como forma de manutenção da produção continua de $\mathrm{H}_{2}$ em ampla faixa de valores das variáveis aplicadas, sustentando a hipótese levantada que os organismos envolvidos se adaptaram às condições de operação impostas, o que comprova a versatilidade das comunidades envolvidas na produção de Hidrogênio estabelecidas no reator.

Tabela 19: Resumo da correlação da produção bruta de hidrogênio com as faixas de valores dos parâmetros aplicados

\begin{tabular}{|c|c|c|c|c|}
\hline \multicolumn{5}{|c|}{ Resumo das Correlações da Produção de Hidrogênio } \\
\hline \multirow{2}{*}{ Tipo de Correlação } & \multicolumn{2}{|c|}{$\begin{array}{c}\text { Faixas de valores das } \\
\text { variáveis }\end{array}$} & \multicolumn{2}{|c|}{$\begin{array}{c}\text { Produção de } \mathrm{H}_{2} \\
\text { respectiva }(\mathrm{L})\end{array}$} \\
\hline & Mínimo & Máximo & Mínimo & Máximo \\
\hline $\mathrm{PBH} 2$ vs pH & 3,37 & 4,88 & 1,88 & 4,30 \\
\hline PBH2 vs Hac (mg.L-1) & 313 & 941 & 3,54 & 3,95 \\
\hline PBH2 vs COV (gDQO.Lr-1.d-1) & 96,17 & 138,07 & 2,46 & 4,57 \\
\hline PBH2 vs \% Remoção de DQO & 1,06 & 18,28 & 2,14 & 3,59 \\
\hline PBH2 vs COV carboidratos (g.Lr-1.d-1) & 41,73 & 75,95 & 1,30 & 4,57 \\
\hline PBH2 vs \% Conversão de Carboidratos & 24,12 & 61,65 & 2,34 & 3,69 \\
\hline
\end{tabular}


Vale ressaltar que não foi realizado correlação para a $\mathrm{PVH}_{2}$, pois conforme aponta os resultados, esta produção $\left(\mathrm{PVH}_{2}\right)$ está intimamente relacionada a produção bruta de hidrogênio $\left(\mathrm{PBH}_{2}\right)$.

A variável a seguir é destacada em termos de rendimento de hidrogênio $\left(\mathrm{YH}_{2}\right)$ a qual é comumente usada para investigações científicas, e assim facilitar a interpretação dos resultados.

A análise temporal para a variável de rendimento de mol de Hidrogênio por mol de carboidrato convertido $-\mathrm{YH}_{2-}\left(\mathrm{molH}_{2}\right.$ molcarboidrato $\left.{ }^{-1}\right)$ mostrou que apesar de haver rendimento de hidrogênio durante todo o período operacional (417 dias) ocorreram pequenas oscilações no decorrer do experimento (Figura 31a). O rendimento de hidrogênio obteve média de 1,52 $\mathrm{molH}_{2} \cdot$ molcarboidrato $^{-1}$, com pico máximo de rendimento de 3,64 $\mathrm{molH}_{2} \cdot$ molcarboidrato $^{-1}$, e rendimento mínimo de $0,10 \mathrm{molH}_{2} \cdot$ molcarboidrato $^{-1}$, conforme aponta a Figura $31 b$.
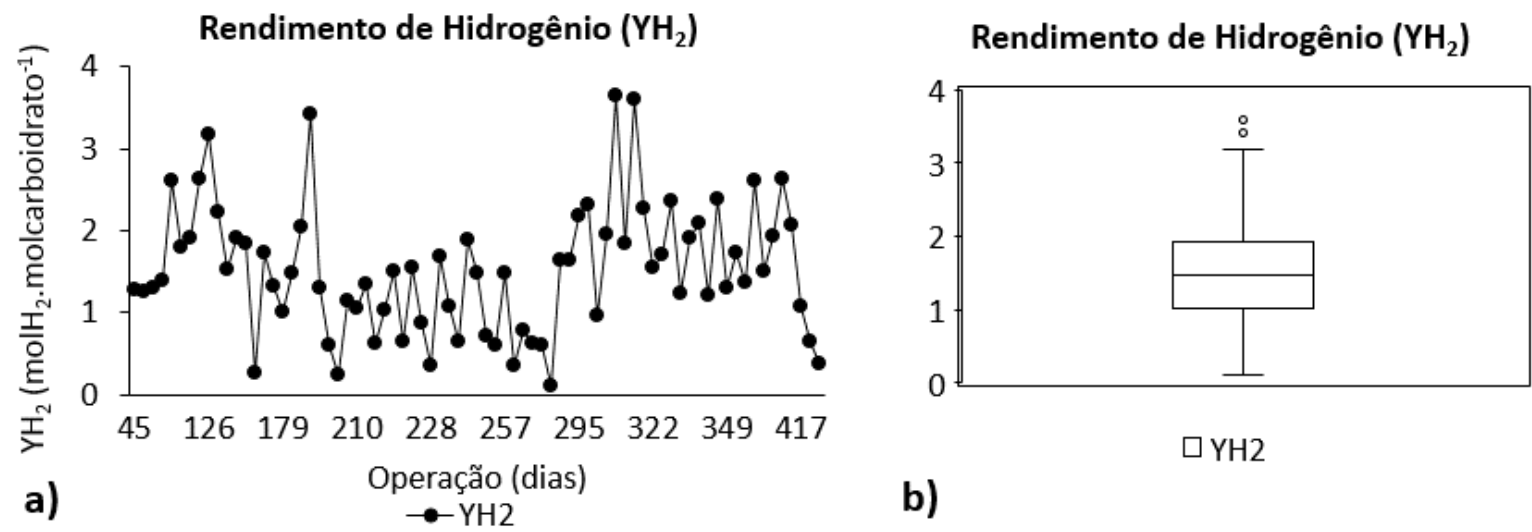

b)

Figura 31: Monitoramento do rendimento de mol de hidrogênio por mol de carboidrato convertido $\left(\mathrm{YH}_{2}\right)$; a) Análise temporal do $\mathrm{YH}_{2}$, b) Análise estatística de boxplot do $\mathrm{YH}_{2}$.

Han et al. (2015) avaliaram a produção fermentativa de hidrogênio extraindo glicose a partir de alguns tipos de rejeitos desperdiçados da cantina da Universidade Hangzhou Dianzi na China. Os autores obtiveram variadas concentrações de glicose no substrato afluente pelo aumento da carga aplicada, e os resultados foram apresentados em relação à quantidade de glicose em g.L $\mathrm{L}^{-1}$ por substrato. Os autores conseguiram rendimento de hidrogênio de 2 $\mathrm{molH}_{2}$.molglicose ${ }^{-1}$ quando aplicaram 21,7 glicose por litro (glic. $\mathrm{L}^{-1}$ ), os resultados apontaram que houve aumento de $7 \%$ no rendimento de $\mathrm{H}_{2}\left(2,13 \mathrm{molH}_{2} \cdot \mathrm{molglicose}^{-1}\right)$ quando aplicaram 36,9 glic. $\mathrm{L}^{-1}$, no entanto com aumento para 46,11 glic. $\mathrm{L}^{-1}$ obtiveram um decréscimo na quantidade de rendimento de hidrogênio em 1,52 $\mathrm{molH}_{2} \cdot$ molglicose $^{-1}$. 
Quedas nas produções de hidrogênio geralmente ocorrem quando se acumulam produtos metabólicos intermediários consumidores de $\mathrm{H}_{2}$, como por exemplo o propionato. Essa tendência foi observada quando houve aumento da carga orgânica volumétrica aplicada, ocasionando inibição por substrato na produção de hidrogênio (ANTONOPOULOU et al., 2008).

Além disso, o consumo de $\mathrm{H}_{2}$ por meio de processos, tais como a metanogênese ou homoacetogênese, também pode causar baixa produção de hidrogênio. No entanto estes processos são altamente dependentes das condições operacionais, tais como pH, TDH, bem como tipo de substrato e suas concentrações inibitórias (KONGJAN et al., 2011) e não foram observados no presente estudo.

Braga et al. (2015) acrescentam que a queda na relação substrato/microrganismo após certo período operacional, conduz a rotas metabólicas menos eficientes, diminuindo dessa maneira o ganho de $\mathrm{H}_{2}$ ao longo do período operacional. Os autores relatam ainda que a produção de $\mathrm{H}_{2}$ depende dos produtos finais formados e os microrganismos podem mudar sua rota metabólica preferencial dependendo das condições impostas ( $\mathrm{pH}, \mathrm{COV}$ específica, potencial redox, pressão parcial de $\mathrm{H}_{2}$, etc.).

Para auxiliar na avaliação da robustez do reator, às condições impostas, em complementação ao resultado de rendimento de $\mathrm{H}_{2}\left(\mathrm{YH}_{2}\right)$ apresentado anteriormente, foram avaliados em conjunto o rendimento bruto de hidrogênio $\left(\mathrm{YPBH}_{2}\right)$ e o rendimento volumétrico $\left(\mathrm{YPVH}_{2}\right)$ ambos por Litro de melaço aplicado $\left(\mathrm{LH}_{2} \cdot \mathrm{Lmelaço}^{-1}\right)$.

A análise temporal para a variável de rendimento da produção bruta de hidrogênio por litro de melaço aplicado $\left(\mathrm{YPBH}_{2}\right)$ apresentou valores máximos de produção de 9,21 $\mathrm{LH}_{2}$. Lmelaço ${ }^{-1}$ e mínimo de 0,95 LH 2. Lmelaço $^{-1}$ (Figura 33a). A análise estatística de boxplot para o rendimento da produção bruta de hidrogênio por litro de melaço aplicado ficou em média

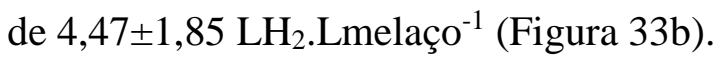


112

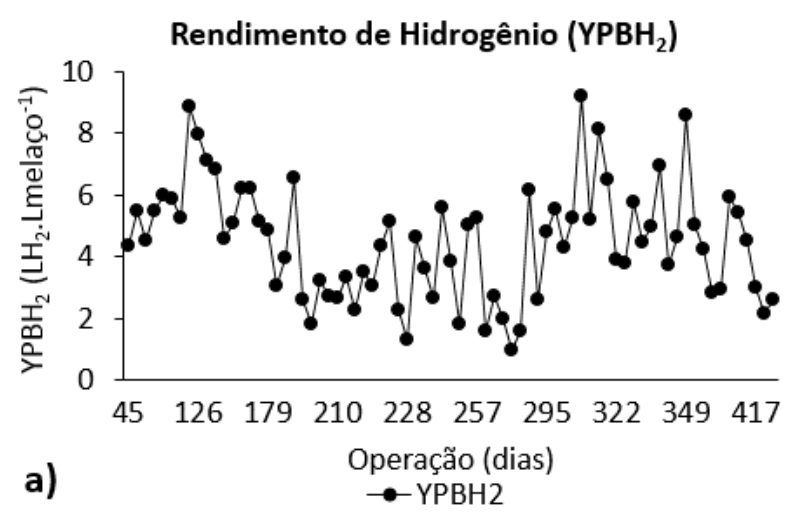

Rendimento de Hidrogênio $\left(\mathrm{YPBH}_{2}\right)$

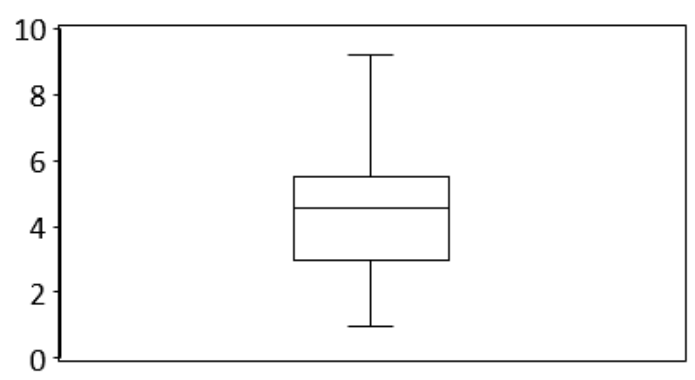

b)

$\square$ YPBH2

Figura 32: Monitoramento do rendimento da produção bruta de hidrogênio por litro de melaço diluído $\left(\mathrm{YPBH}_{2}\right)$; a) Análise temporal da $\mathrm{YPBH}_{2}$, b) Análise estatística de boxplot $\mathrm{YPBH}_{2}$.

A análise temporal para a variável de rendimento da produção volumétrica de hidrogênio por litro de melaço diluído $\left(\mathrm{YPVH}_{2}\right)$ obteve valores com máximo de produção de

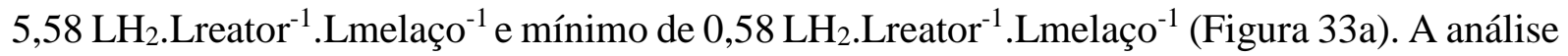
estatística de boxplot para o rendimento da produção volumétrica de hidrogênio por litro de

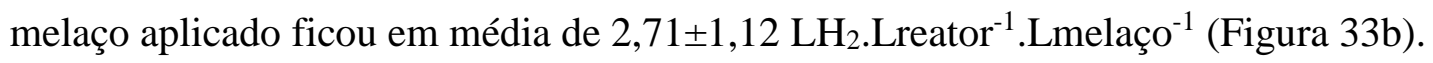
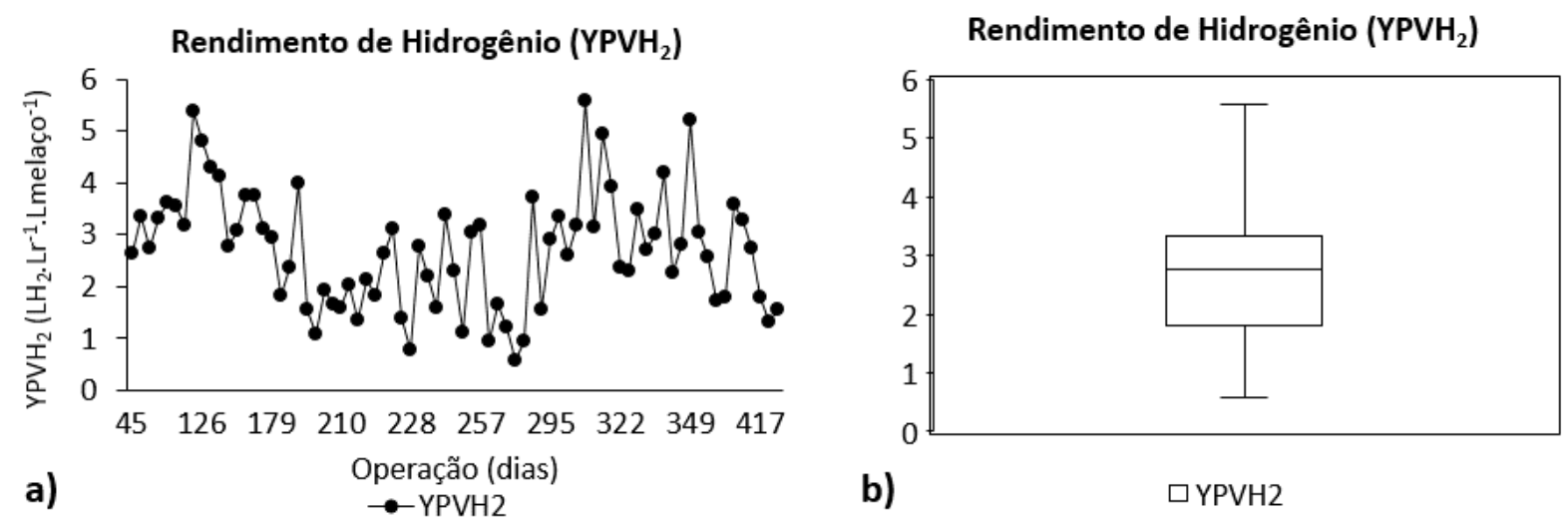

Figura 33: Monitoramento do rendimento da produção volumétrica de hidrogênio por litro de melaço diluído $\left(\mathrm{YPVH}_{2}\right)$; a) Análise temporal da $\mathrm{YPVH}_{2}$, b) Análise estatística de boxplot $\mathrm{YPVH}_{2}$.

Visão geral do resumo dos resultados comparativos dos rendimentos da produção de hidrogênio por litro de melaço aplicado pode ser visualizado na Tabela 20. 
Tabela 20: Comparativo dos rendimentos de hidrogênio por litro de melaço aplicado

\section{Comparativo dos Rendimentos de Hidrogênio por Litro de Melaço}

Variáveis

Rendimentos de Hidrogênio

\begin{tabular}{|c|c|c|c|}
\hline \multicolumn{2}{|c|}{ Variáveis } & \multirow{2}{*}{$\begin{array}{c}\mathbf{Y P B H}_{2} \\
\left(\mathbf{L H}_{\left.2 . \text { Lmelaço }^{-1}\right)}\right.\end{array}$} & \multirow{2}{*}{$\begin{array}{c}\text { YPVH }_{2} \\
\left(\mathbf{L H}_{\left.2 . \text { Lreator }^{-1} \cdot \text { Lmelaço }^{-1}\right)}\right.\end{array}$} \\
\hline \multirow{4}{*}{ Reator Acidogênico } & Média & & \\
\hline & Máximo & 9,21 & 5,58 \\
\hline & Mínimo & 0,95 & 0,58 \\
\hline & Desvio Padrão & $\pm 1,85$ & $\pm 1,12$ \\
\hline
\end{tabular}

A partir dos resultados obtidos pelo rendimento da produção de hidrogênio por litro de melaço aplicado $\left(\mathrm{YPBH}_{2}\right.$ e $\left.\mathrm{YPVH}_{2}\right)$, pode-se chegar aos cálculos específicos para este estudo do rendimento de hidrogênio por quilograma $(\mathrm{kg})$ de melaço aplicado $\left(\mathrm{ZPBH}_{2}\right)$.

O rendimento da $\mathrm{ZPBH}_{2}$ máximo foi de $805,30 \mathrm{LH}_{2} \cdot \mathrm{Kgmelaço}^{-1}$ e valor de produção mínima de 84,40 $\mathrm{LH}_{2} . \mathrm{Kgmelaço}^{-1}$ (Figura 34a). A análise estatística de boxplot da $\mathrm{ZPBH}_{2}$ apontou valor médio de 391,16 $\pm 162,03 \mathrm{LH}_{2} \cdot \mathrm{Kgmelaço}^{-1}$ (Figura 34b).
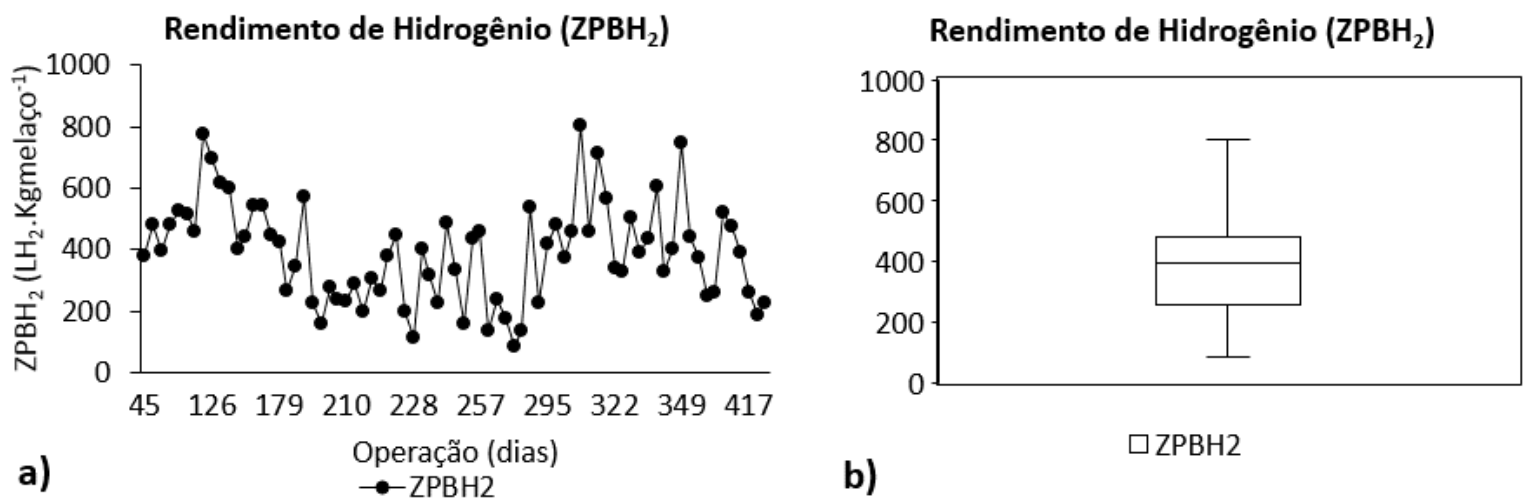

Figura 34: Monitoramento do rendimento da produção de hidrogênio por $\mathrm{Kg}$ de melaço aplicado $\left(\mathrm{ZPBH}_{2}\right)$; a) Análise temporal da $\mathrm{ZPBH}_{2}$, b) Análise estatística de boxplot $\mathrm{ZPBH}_{2}$.

Igualmente aos resultados apontados anteriormente pode observar-se que houve rendimento ao longo de todo o período operacional do reator acidogênico comprovando a eficácia das estratégias utilizadas. O resumo dos dados obtidos para o rendimento da $\mathrm{ZPBH}_{2}$ está apresentado na Tabela 21. 
114

Tabela 21: Rendimento da produção de hidrogênio por kg de melaço aplicado

Rendimentos de Hidrogênio por Kg de Melaço Aplicado

Variáveis

Rendimento de Hidrogênio

\begin{tabular}{|c|c|c|}
\hline \multicolumn{2}{|c|}{ Variáveis } & $\begin{array}{r}\mathrm{ZPBH}_{2} \\
\text { (LH } 2 . \text { Kgmela }\end{array}$ \\
\hline \multirow{4}{*}{ Reator Acidogênico } & Média & 391,16 \\
\hline & Máximo & 805,30 \\
\hline & Mínimo & 83,40 \\
\hline & Desvio Padrão & $\pm 162,03$ \\
\hline
\end{tabular}

Analisando os resultados, observa-se que houve alta eficiência do reator com base na produção de hidrogênio por massa de melaço aplicada $\left(\mathrm{ZPBH}_{2}\right)$. Os dados obtidos podem auxiliar em tomadas de decisão quanto a aplicação do melaço nos biorreatores para geração de energia.

Visto a produção de hidrogênio por kg de melaço aplicado juntamente com os resultados obtidos nas variáveis aplicadas neste estudo, pode-se afirmar que a produção de hidrogênio pode ser também fortemente influenciada pelas características da fonte de carbono utilizadas e modo de aplicação das mesmas.

Sustentando essa hipótese, os resultados obtidos nessa etapa do trabalho, aliado às estratégias operacionais adotadas (tipo de substrato, TDH, $\mathrm{COV}$ e temperatura $55^{\circ} \mathrm{C}$ ), direcionaram a via metabólica dos organismos envolvidos para a produção de hidrogênio.

A versatilidade e a capacidade dos microrganismos envolvidos na produção de hidrogênio de se adaptarem as condições impostas, mantendo a produção de hidrogênio por longo período de tempo (417 dias) foram demonstradas.

Apesar do lodo utilizado para inocular o reator acidogênico não ter passado por nenhum tratamento de inativação e morte dos microrganismos metanogênicos, nenhum traço de metano foi detectado ao longo de todo o período operacional, confirmando que as estratégias empregadas para manter a acidogênese (produção de hidrogênio) por longo período de tempo, suprimiram completamente a atuação dos organismos produtores de metano.

A fim de obter uma visão global do desempenho do reator neste estudo em processo acidogênico em reatores de duas fases operados em condição termofílica $\left(55^{\circ} \mathrm{C}\right)$, destaca-se a Tabela 22 com resumo dos resultados obtidos no experimento. 
Tabela 22: Visão geral do desempenho do reator acidogênico

\section{Visão Geral e Análise do Desempenho do Reator Acidogênico}

Parâmetro

Afluente

Efluente

\begin{tabular}{|c|c|c|c|}
\hline \multirow{3}{*}{$\mathrm{pH}$} & Média & 5,32 & 4,16 \\
\hline & Máximo & 6,54 & 4,88 \\
\hline & Mínimo & 4,45 & 3,37 \\
\hline \multirow{3}{*}{$\begin{array}{l}\text { Matéria orgânica expressa em DQO } \\
\left(\text { g. } L^{-1}\right)\end{array}$} & Média & 9,94 & 9,20 \\
\hline & Máximo & 11,51 & 11,20 \\
\hline & Mínimo & 8,01 & 7,47 \\
\hline \multirow{3}{*}{$\begin{array}{l}\text { Ácidos totais } \\
\left(\mathrm{mg} \cdot \mathrm{L}^{-1}\right)\end{array}$} & Média & 245 & 602 \\
\hline & Máximo & 395 & 1029 \\
\hline & Mínimo & 151 & 313 \\
\hline \multirow{3}{*}{$\begin{array}{l}\text { Carboidratos totais } \\
\left(\mathrm{mg} . \mathrm{L}^{-1}\right)\end{array}$} & Média & 4766 & 2544 \\
\hline & Máximo & 6330 & 3595 \\
\hline & Mínimo & 3477 & 1752 \\
\hline \multirow{3}{*}{$\begin{array}{l}\text { Remoção de DQO } \\
\left(\text { g.L. }{ }^{-1}\right)\end{array}$} & Média & - & 0,74 \\
\hline & Máximo & - & 2,02 \\
\hline & Mínimo & - & 0,10 \\
\hline \multirow{3}{*}{$\begin{array}{l}\text { Porcentagem de remoção de DQO } \\
(\%)\end{array}$} & Média & - & $7,39 \%$ \\
\hline & Máximo & - & $18,28 \%$ \\
\hline & Mínimo & - & $1,06 \%$ \\
\hline \multirow{3}{*}{$\begin{array}{l}\text { Conversão de carboidratos } \\
\left(\mathrm{mg} . \mathrm{L}^{-1}\right)\end{array}$} & Média & - & 2222 \\
\hline & Máximo & - & 3345 \\
\hline & Mínimo & - & 911 \\
\hline \multirow{3}{*}{$\begin{array}{l}\text { Porcentagem de conversão de carboidratos } \\
(\%)\end{array}$} & Média & - & $46,42 \%$ \\
\hline & Máximo & - & $61,65 \%$ \\
\hline & Mínimo & - & $24,12 \%$ \\
\hline \multirow{3}{*}{$\begin{array}{l}\text { Porcentagem da composição do biogás } \\
\left(\% \mathrm{H}_{2}\right)\end{array}$} & Média & - & $55,39 \%$ \\
\hline & Máximo & - & $78,09 \%$ \\
\hline & Mínimo & - & $19,04 \%$ \\
\hline \multirow{3}{*}{$\begin{array}{l}\text { Produção bruta de hidrogênio }\left(\mathrm{PBH}_{2}\right) \\
\left(\mathrm{LH}_{2} \cdot \mathrm{dia}^{-1}\right)\end{array}$} & Média & - & 3,69 \\
\hline & Máximo & - & 7,60 \\
\hline & Mínimo & - & 0,79 \\
\hline \multirow{3}{*}{$\begin{array}{l}\text { Produção volumétrica de hidrogênio }\left(\mathrm{PVH}_{2}\right) \\
\left(\mathrm{LH}_{2} \text {.Lreator }{ }^{-1} \cdot \text { dia }^{-1}\right)\end{array}$} & Média & - & 2,24 \\
\hline & Máximo & - & 4,61 \\
\hline & Mínimo & - & 0,48 \\
\hline \multirow{3}{*}{$\begin{array}{l}\text { Rendimento de hidrogênio }\left(\mathrm{YH}_{2}\right) \\
\left(\mathrm{molH}_{2} \cdot \text { molcarboidrato }^{-1}\right)\end{array}$} & Média & - & 1,52 \\
\hline & Máximo & - & 3,64 \\
\hline & Mínimo & - & 0,10 \\
\hline \multirow{3}{*}{$\begin{array}{l}\text { Rendimento bruto de hidrogênio }\left(\mathrm{YPBH}_{2}\right) \\
\left(\mathrm{LH}_{2} \cdot \mathrm{Lmelaço}^{-1}\right)\end{array}$} & Média & - & 4,47 \\
\hline & Máximo & - & 9,21 \\
\hline & Mínimo & - & 0,95 \\
\hline \multirow{3}{*}{$\begin{array}{l}\text { Rendimento volumétrico de hidrogênio }\left(\mathrm{YPVH}_{2}\right) \\
\left(\mathrm{LH}_{2} \cdot \mathrm{Lmelaço}^{-1} \cdot \mathrm{dia}^{-1}\right)\end{array}$} & Média & - & 2,71 \\
\hline & Máximo & - & 5,58 \\
\hline & Mínimo & - & 0,58 \\
\hline \multirow{3}{*}{$\begin{array}{l}\text { Rendimento de hidrogênio por kg melaço }\left(\mathrm{ZPBH}_{2}\right) \\
\left(\mathrm{LH}_{2} . \mathrm{Kgmelaço}^{-1}\right)\end{array}$} & Média & - & 391,16 \\
\hline & Máximo & - & 805,30 \\
\hline & Mínimo & - & 83,40 \\
\hline
\end{tabular}


5.2.2 Análise do Desempenho do Reator Metanogênico Instalado Sequencialmente ao Reator Acidogênico

O desempenho do reator metanogênico foi avaliado pelo comportamento quanto às variáveis aplicadas de controle de $\mathrm{pH}$, geração de alcalinidade, pela eficiência de remoção de DQO e produção de metano. Para isso foram aplicadas 7 fases operacionais distintas (I-VII). O comportamento global do reator (conjunto das fases) também foi analisado e apresentados neste item. Os dados obtidos foram apresentados na forma temporal e por análise estatística realizada pelos métodos de boxplot e coeficiente de correlação, além da comparação com os resultados da literatura pertinente.

Destaca-se que o reator ora denominado "metanogênico" desempenhou a digestão anaeróbia completa, uma vez que parte do carboidrato não acidificado no reator acidogênico era conduzida ao segundo reator. Portanto, o leitor deve ter em mente que, embora a geração de metano tenha sido o alvo da pesquisa para o segundo reator, ambas as fases da digestão metanogênica (ácida e metanogênica) tiveram lugar no reator 2. A geração de $\mathrm{H}_{2}$ no segundo reator não foi observada, uma vez que a metanogênese hidrogenotrófica pode ter ocorrido.

O reator metanogênico foi operado por 251 dias consecutivos alimentado com efluente do reator acidogênico (denominada de DQO afluente). As fases (I-VII) foram avaliadas pelo incremento da carga orgânica volumétrica aplicada ao reator metanogênico $(\mathrm{COVm})$, que se deu pelo aumento da vazão de entrada e consequente diminuição do TDH. Foi realizado controle do $\mathrm{pH}$ afluente com bicarbonato de sódio $\left(\mathrm{NaHCO}_{3}\right)$ como solução tampão. Inicialmente, $1,2 \mathrm{~g}$ de $\mathrm{NaHCO}_{3}$ para cada grama de DQO aplicada foi adicionada por litro de substrato, regredindo com o passar das fases para $0,2 \mathrm{~g}$ no final do período operacional (Tabela 23).

Tabela 23: Fases avaliadas na metanogênese

\begin{tabular}{|c|c|c|c|c|c|c|c|}
\hline \multirow{2}{*}{ Variáveis } & \multicolumn{7}{|c|}{ Fases Avaliadas na Metanogênese } \\
\hline & I & II & III & IV & $\mathbf{V}$ & VI & VII \\
\hline DQO Afluente* (gDQO.L L $^{-1}$ ) & 9 & 9 & 9 & 9 & 14 & 17 & 11 \\
\hline TDH (horas) & 240 & 96 & 48 & 32 & 34 & 16 & 12 \\
\hline COVm (gDQO.Lreator $\left.{ }^{-1} \cdot \mathrm{dia}^{-1}\right)$ & 1,0 & 2,0 & 5,0 & 7,0 & 14,0 & 26,0 & 17,5 \\
\hline $\mathrm{NaHCO}_{3}\left(\right.$ g.gDQO.L $\left.{ }^{-1}\right)$ & 1,2 & 1,0 & 0,8 & 0,6 & 0,4 & 0,2 & 0,2 \\
\hline
\end{tabular}

*Condicionada ao efluente do reator acidogênico 
A Figura 35a aponta os valores obtidos para as COVm (teóricos e práticos) e suas respectivas fases. Observa-se que a partir da fase $\mathrm{V}$ ocorreram oscilações em relação às cargas aplicadas ao reator metanogênico, ocasionado pelo aumento da vazão do reator e pela dificuldade de controle do afluente introduzido. A análise estatística de boxplot (Figura 35b) corrobora com os dados temporais, demostrando que a partir da fase $\mathrm{V}$ houve oscilações afluente da COVm com maior resiliência dos dados obtidos, ocorrendo oscilação também para as Fases VI e VII com maiores cargas orgânicas volumétricas aplicadas, do que programado.
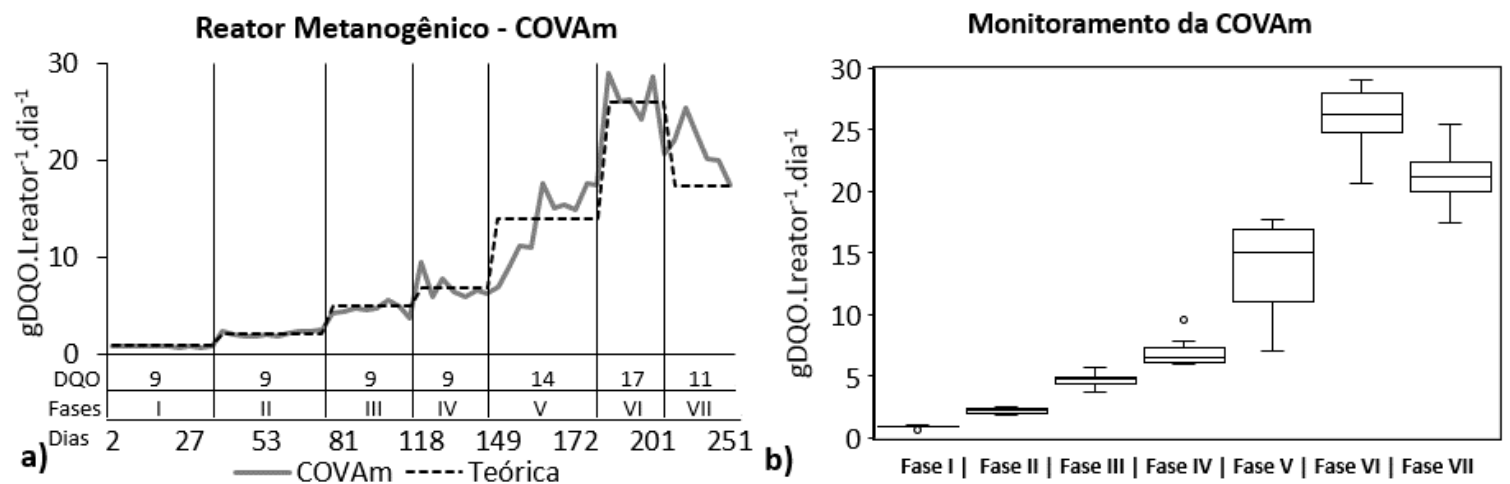

Figura 35: Monitoramento da COVm; a) Monitoramento temporal da COVm, b) Análise estatística de boxplot da COVm.

Como exposto anteriormente, a adição de $\mathrm{NaHCO}_{3}$ ocorreu para o tamponamento do $\mathrm{pH}$ afluente, para favorecer o desenvolvimento do reator metanogênico. Com o estabelecimento do processo metanogênico, a geração de alcalinidade, principalmente a partir da conversão de acetato a metano, possibilitou a diminuição da adição com o passar das fases (Figura 36a, b). O

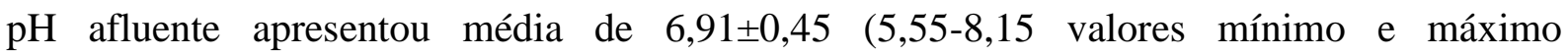
respectivamente), enquanto o $\mathrm{pH}$ efluente foi de $8,69 \pm 0,35(8,15-9,60)$, indicando que houve geração de alcalinidade e consequente manutenção da metanogênese em todas as fases conforme indicado na análise de boxplot do monitoramento global do $\mathrm{pH}$ (Figura 36c). 


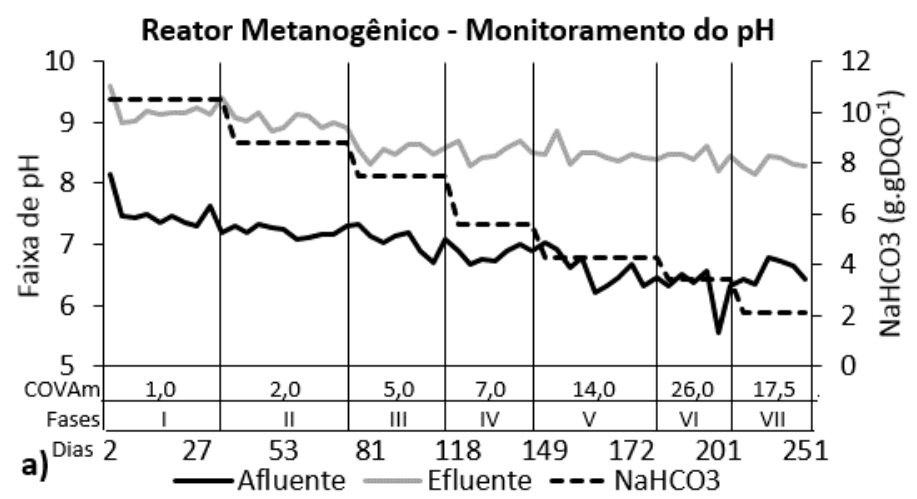

Monitoramento do $\mathrm{pH}$

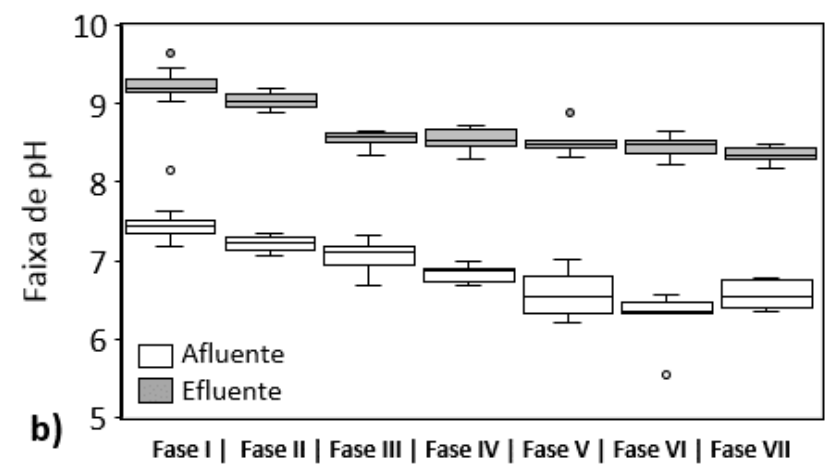

Monitoramento Global do pH

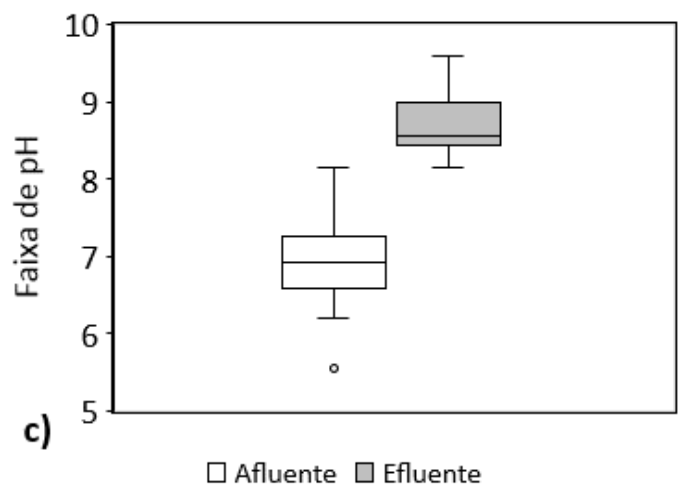

Figura 36: Monitoramento e controle do $\mathrm{pH}$; a) Monitoramento e controle temporal do $\mathrm{pH}$, b) Análise estatística de boxplot do monitoramento do $\mathrm{pH}$, c) monitoramento global do $\mathrm{pH}$.

Para verificar a estabilidade operacional, o monitoramento da geração de alcalinidade foi realizado pela relação da Alcalinidade Intermediária pela Alcalinidade Parcial (AI/AP).

O valor da relação AI/AP global durante o período de operação foi de média de 0,53 $\pm 0,08$ (Figura 37a).

A análise temporal da relação AI/AP apresentada na Figura 37b apontou instabilidade momentânea do reator quando houve troca de fases, ao qual podem ser creditados devido ao aumento de COVm. Prontamente observou-se estabilização da relação em valores próximos ao observado ao longo da operação do reator, de acordo com os demais fatores de desempenho.

A análise estatística de boxplot mostrou que os maiores pontos de instabilidade momentânea (outliers) ocorreram nas Fases I, III e IV, no entanto as medianas apresentadas no gráfico para todas as fases estudadas ficaram em níveis praticamente estáveis demonstrando a robustez do reator na manutenção da geração da alcalinidade e, consequente adaptação às condições impostas (Figura 37c). 


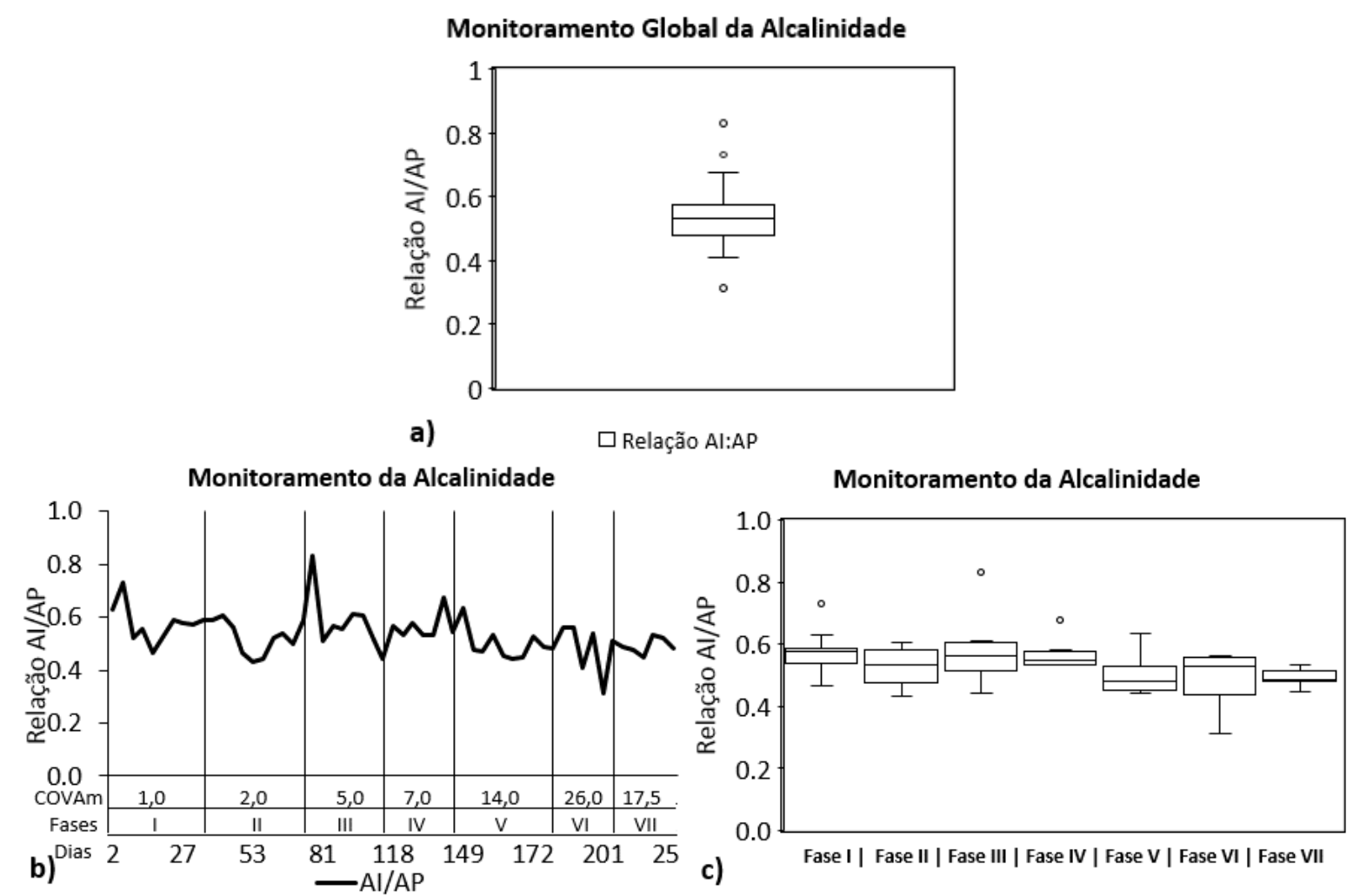

Figura 37: Monitoramento da geração de alcalinidade pela relação AI/AP; a) Monitoramento global da relação AI/AP, b) Monitoramento temporal da relação AI/AP, c) Análise estatística de boxplot da relação AI/AP.

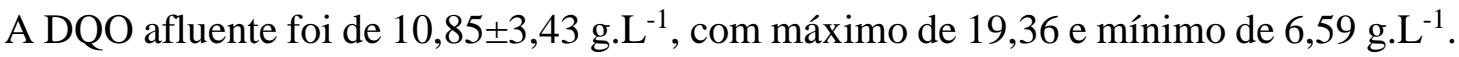
A remoção global de DQO foi de 8,58 $\pm 3,03$ g.L $\mathrm{L}^{-1}$ com máximo e mínimo de 16,51 e 4,72 g.L $\mathrm{L}^{-1}$, respectivamente (Figura 38a). A eficiência de remoção global de DQO para o reator metanogênico foi em média de 78,41+5,73\%, atingindo valor máximo de 90,53\% e valor mínimo de 66,27\% (Figura 38b).

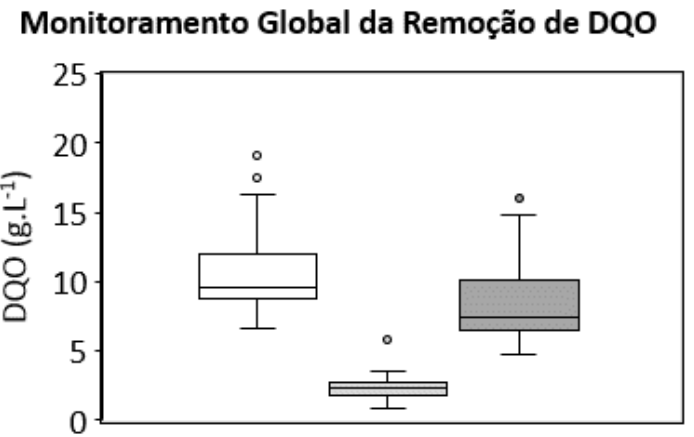

a)

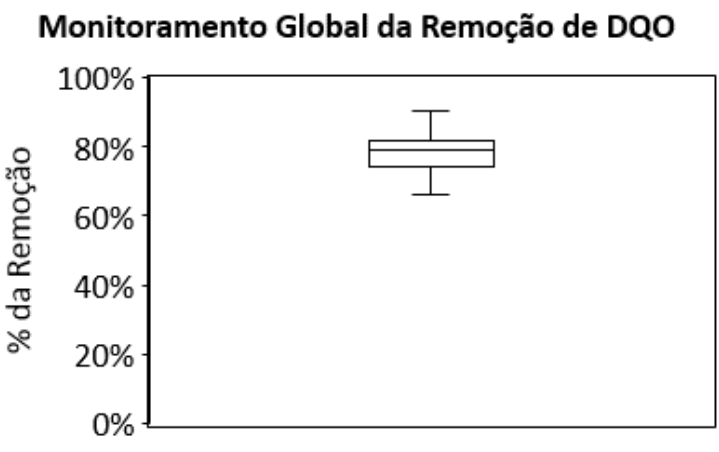

b) $\quad \square \%$ da Remoção Global de DQO

Figura 38: Análise estatística de boxplot da eficiência da remoção global de DQO; a) análise da eficiência da remoção global de DQO, b) Análise da porcentagem da eficiência da remoção global de DQO. 
Comportamento semelhante foi relatado por Ferraz et al. (2016) em sistema de duas fases. Estes autores verificaram que o aumento da COV por meio da redução do TDH no reator metanogênico aliado a adição de $\mathrm{NaHCO}_{3}$ ao afluente apresentaram forte influência na remoção da matéria orgânica, alcançando valor médio acima de 74\% de eficiência de remoção de DQO.

A análise temporal de remoção da DQO por fases demonstra que mesmo com o incremento da carga orgânica aplicada ao reator pelo aumento da vazão afluente, a remoção de DQO manteve-se praticamente estável em todas as fases com média acima de 70\%. As fases V e VI tiveram maior variação na DQO afluente, embora a remoção e a DQO efluente mantiveram-se estáveis, no entanto com maior oscilação para a fase VI (Figura 39a).

A análise estatística de boxplot da remoção de DQO por fases apresentado na Figura $39 \mathrm{~b}$, reafirmou o dado temporal apresentado anteriormente, quando aplicadas maiores cargas orgânicas nas fases V e VI ocorreram maiores oscilações da DQO afluente e houve as maiores médias de remoção de DQO comparado de forma escalonar com as fases I, II, III, IV e VII, no entanto com maior variação nos dados obtidos (Figura 39b). Observa-se na Figura 39c da análise estatística de boxplot da porcentagem de eficiência da remoção de DQO por fases, que a maior eficiência de remoção ocorreu para a fase IV com média de 83,22 $44,97 \%$, e a menor

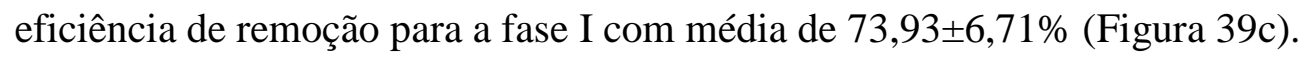
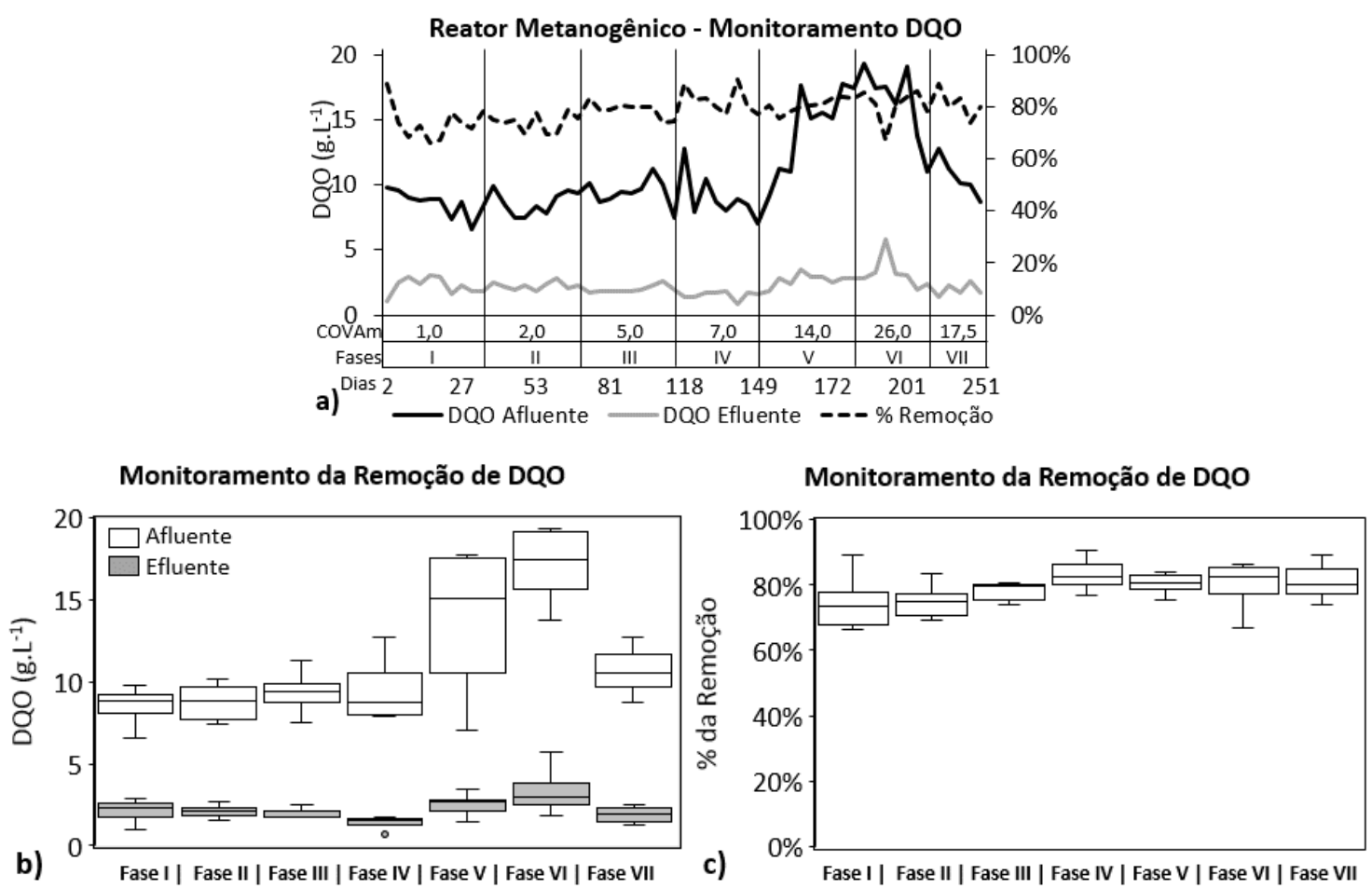

Figura 39: Monitoramento da eficiência da remoção de DQO por fases; a) Monitoramento temporal da eficiência remoção de DQO, b) Análise estatística de boxplot da eficiência de remoção de DQO, c) Análise estatística de boxplot da porcentagem da eficiência da remoção de DQO. 
Verificou-se que com o aumento da vazão afluente e diminuição do TDH, ocorreu a manutenção da remoção de DQO com valores médios acima de $70 \%$ em todas as fases, indicando adaptação da comunidade de microrganismos envolvidos na metanogênese.

Afirmando esta hipótese, mesmo com o reator exposto a sobrecargas na Fase V (14gDQO.L $\mathrm{L}^{-1}$ e TDH de 34h) e na Fase VI (17gDQO.L ${ }^{-1}$ e TDH de 16h), o reator metanogênico manteve a estabilidade de remoção de DQO, com oscilação maior para a Fase VI. No entanto, o reator retomou a estabilidade com a redução da COVm pelo ajuste da DQO afluente na Fase VII (11gDQO.L ${ }^{-1}$ e TDH de $\left.12 \mathrm{~h}\right)$.

Durante todo o período operacional foi detectada a presença de metano (Figura 40), o que indica claramente a manutenção da metanogênese com o aumento de carga. A maior porcentagem foi observada na fase $\mathrm{V}$ com média de 58,22 $\pm 4,83 \%$ (66,77-51,67\%, máximo e mínimo respectivamente) e a menor porcentagem foi para a fase III com média de $42,12 \pm 8,80 \%$ (61,93-34,20\%). Traços de hidrogênio também foram observados em todas as fases, com valores de $0,06 \%$ a $0,20 \%$ (Figura 40 ).

\section{Composição do Biogás}

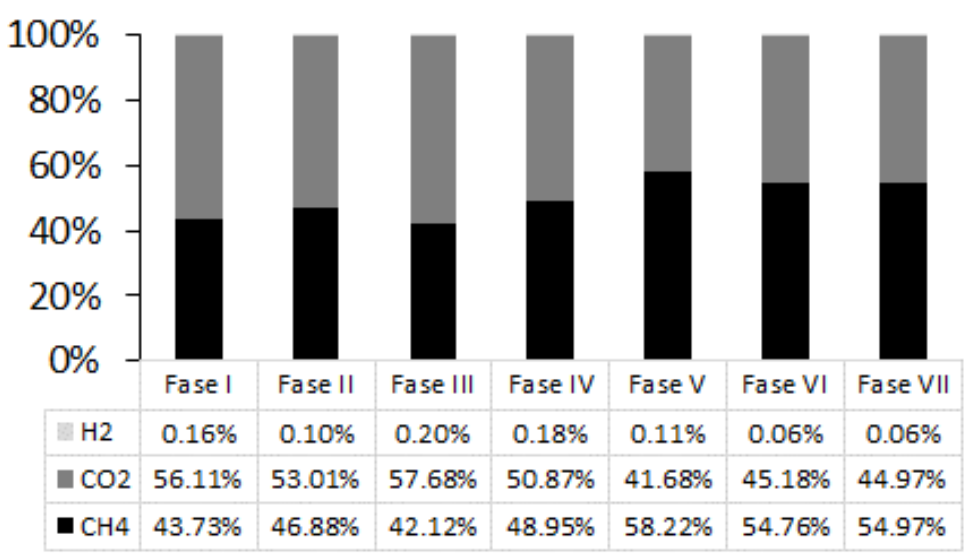

Figura 40: Monitoramento por fases da composição do biogás

Conforme aponta a Figura 41, pela análise estatística de boxplot a porcentagem de metano no biogás ficou acima de $40 \%$, indicando estabilidade na produção de metano. 


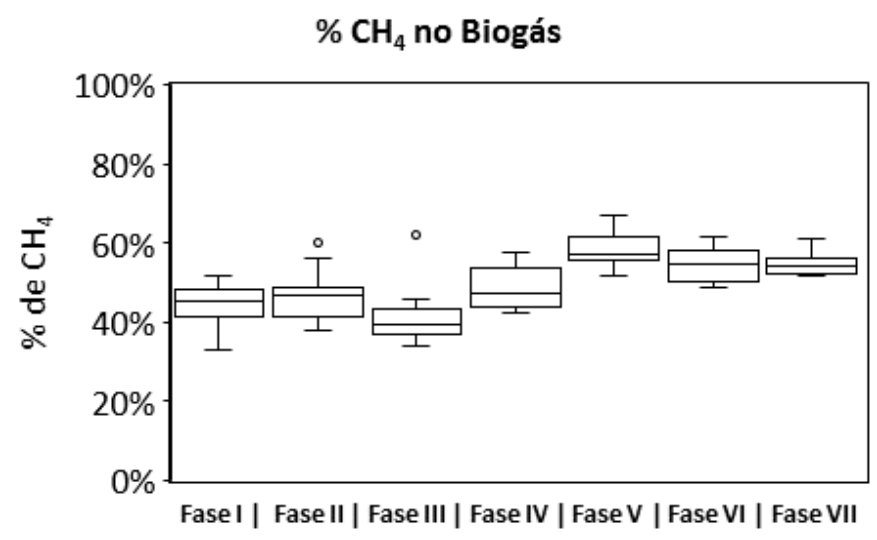

Figura 41: Análise estatística de boxplot da porcentagem de metano no biogás

Como observado na Figura 42a, a produção bruta de metano $\left(\mathrm{PBCH}_{4}\right)$ aumentou conforme houve aporte da carga orgânica pelo incremento de vazão até a fase V (14,0 gDQO.Lr-1 dia $^{-1}$ e TDH 34h), apesar de não apresentar taxa da mesma ordem de grandeza do aumento de COVm as fases. Com a diminuição do aporte de DQO afluente na fase VII (17,5 gDQO.Lr-1 ${ }^{-1} \cdot \mathrm{dia}^{-1}$ e TDH $12 \mathrm{~h}$ ), a produção de metano retomou seu crescimento (Figura 42b).
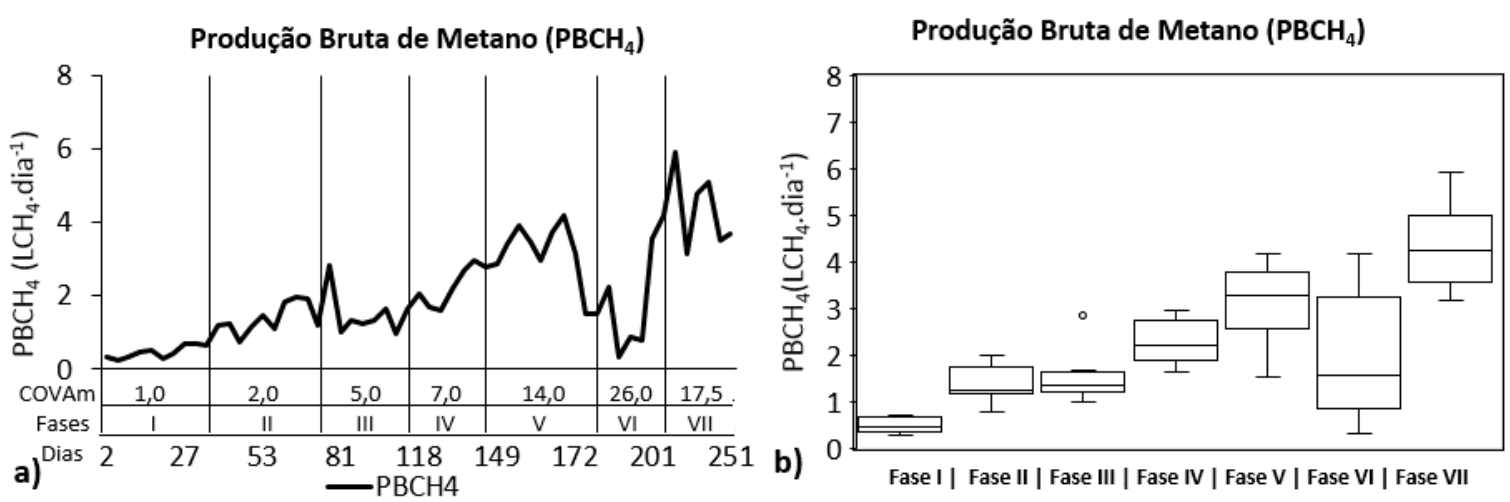

Figura 42: Monitoramento da produção bruta de metano $\left(\mathrm{PBCH}_{4}\right)$; a) Monitoramento temporal da $\mathrm{PBCH}_{4}$, b) Análise estatística de boxplot da $\mathrm{PBCH}_{4}$.

Comportamento semelhante pode ser observado para o monitoramento da produção volumétrica de metano $\left(\mathrm{PVCH}_{4}\right)$. A análise do monitoramento temporal da $\mathrm{PVCH}_{4}$ indica que que com o aumento da COVm na Fase VI de 14 para 26 gDQO.Lr ${ }^{-1} \cdot \operatorname{dia}^{-1}$ e TDH de 24 para $16 \mathrm{~h}$ houve queda na produção de metano (Figura 43a). 

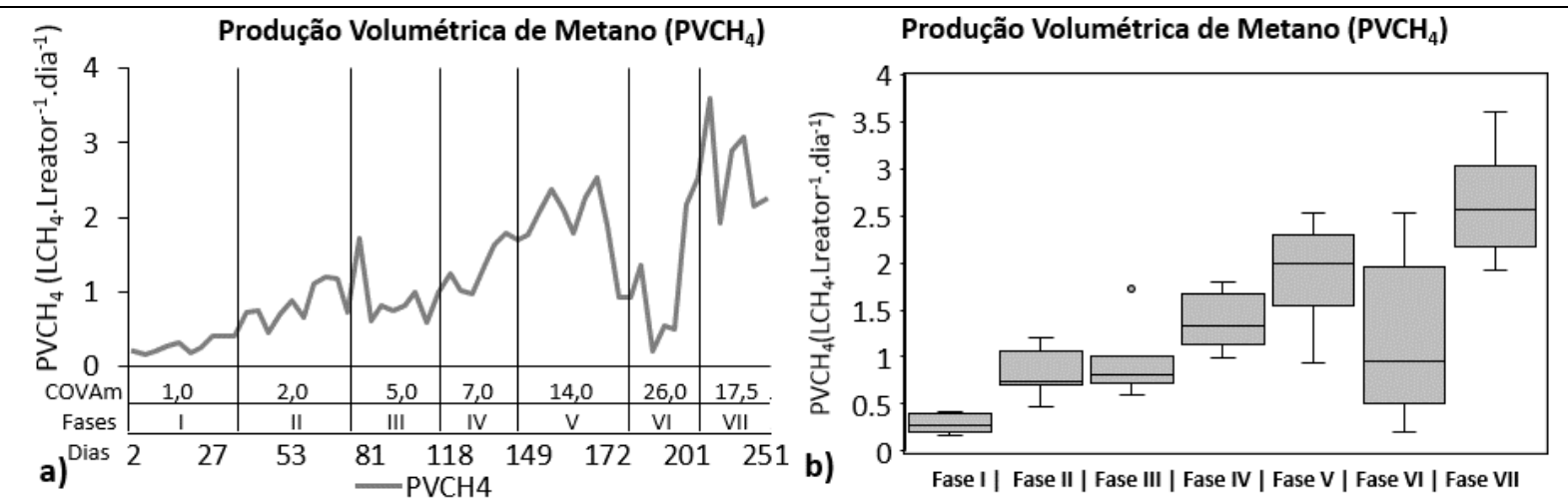

Figura 43: Monitoramento da produção volumétrica de metano $\left(\mathrm{PVCH}_{4}\right)$; a) Monitoramento temporal da $\left.\mathrm{PVCH}_{4}, \mathbf{b}\right)$ Análise estatística de boxplot da $\mathrm{PVCH}_{4}$.

Nos dados obtidos pode-se observar que a Fase V obteve-se maior eficiência de produção de metano, relacionado com as variáveis obtidas (estabilidade na remoção de DQO e geração de alcalinidade) e as condições impostas de COVm e ao TDH (14 gDQO.Lr ${ }^{-1} \cdot \mathrm{d}^{-1}$ e TDH de 34h). Embora a Fase VII (17,5 gDQO.Lr ${ }^{-1} \cdot \mathrm{d}^{-1}$ e TDH de 12h) obteve-se maior média de produção de $\mathrm{CH}_{4}$, o desempenho foi menos estável em relação as variáveis analisadas.

Conforme exposto quando o objetivo do processo for a geração de compostos energéticos, como o metano, a operação em condições da fase VII, com reduzido TDH pode ser mais interessante.

Visão comparativa dos valores obtidos entre as produções de metano $\left(\mathrm{PBCH}_{4} \mathrm{e} \mathrm{PVCH}_{4}\right)$ pode ser verificada na Tabela 24.

Tabela 24: Valores obtidos nas produções de metano, $\mathrm{PBCH}_{4}$ e $\mathrm{PVCH}_{4}$

\begin{tabular}{lcccccccc}
\hline \multirow{2}{*}{ Variáveis } & & \multicolumn{7}{c}{ Produção de Metano por Fases } \\
\cline { 3 - 9 } & & I & II & III & IV & V & VI & VII \\
\hline \multirow{2}{*}{ Mediana } & 0,44 & 1,22 & 1,34 & 2,20 & 3,29 & 1,57 & 4,23 \\
$\left(\mathrm{LCH}_{4} \cdot \mathrm{dia}_{4}^{-1}\right)$ & Máximo & 1,80 & 1,98 & 2,83 & 2,97 & 4,19 & 4,18 & 5,94 \\
& Mínimo & 0,26 & 0,77 & 0,97 & 1,63 & 1,53 & 0,33 & 3,17 \\
& Desvio & $\pm 0,56$ & $\pm 0,40$ & $\pm 0,59$ & $\pm 0,54$ & $\pm 0,91$ & $\pm 1,60$ & $\pm 1,60$ \\
\hline \multirow{2}{*}{$\mathrm{PVCH}_{4}$} & Mediana & 0,27 & 0,74 & 0,81 & 1,33 & 1,99 & 0,95 & 2,56 \\
$\left(\mathrm{LCH}_{4} \cdot \mathrm{Lr}^{-1} \cdot \mathrm{dia}^{-1}\right)$ & Máximo & 1,09 & 1,20 & 1,72 & 1,80 & 2,54 & 2,54 & 3,60 \\
& Mínimo & 0,16 & 0,46 & 0,59 & 0,99 & 0,93 & 0,20 & 1,92 \\
& Desvio & $\pm 0,01$ & $\pm 0,25$ & $\pm 0,36$ & $\pm 0,33$ & $\pm 0,55$ & $\pm 0,97$ & $\pm 0,65$ \\
\hline
\end{tabular}


Análise estatística do coeficiente de correlação foi realizada para analisar a influência entre a produção bruta de metano $\left(\mathrm{PBCH}_{4}\right)$ e as variáveis aplicadas de $\mathrm{pH}$ afluente, relação AI/AP, remoção de DQO e COVm (Figura 44).
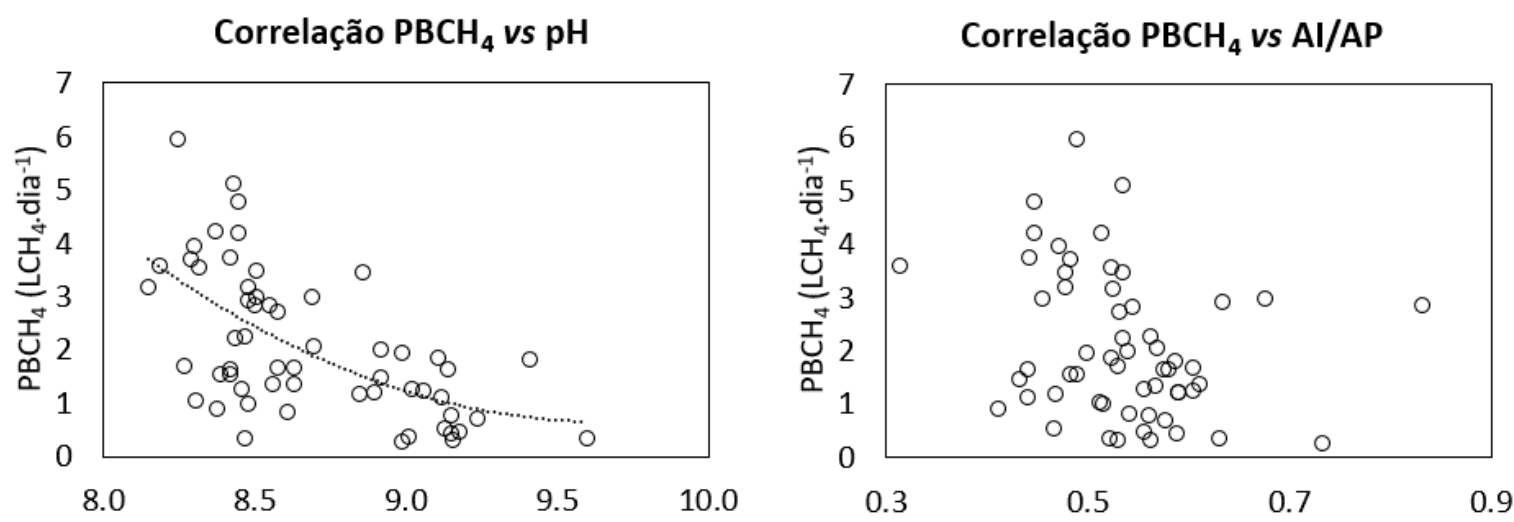

a)

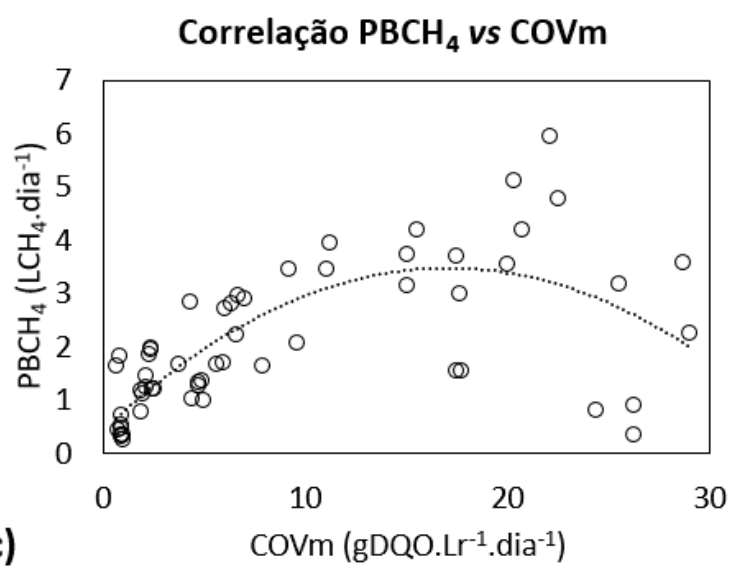

b)

$$
\mathrm{Al} / \mathrm{AP}
$$

\section{Correlação $\mathrm{PBCH}_{4}$ vs DQo Afluente}

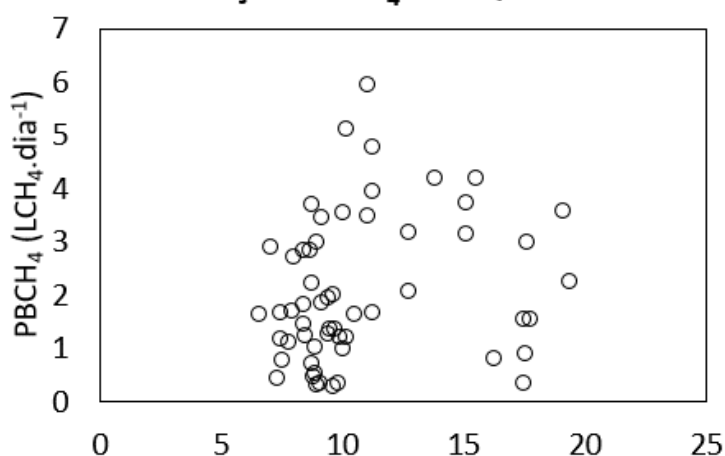

d)

DQO Afluente (gDQO. $\left.\mathrm{L}^{-1}\right)$

Figura 44: Análise estatística do coeficiente de correlação da produção bruta de metano $\left(\mathrm{PBCH}_{4}\right)$; a) Correlação $\mathrm{PBCH}_{4}$ vs $\mathrm{pH}$ efluente, b) Correlação $\mathrm{PBCH}_{4}$ vs relação AI/AP, c) Correlação $\mathrm{PBCH}_{4}$ vs $\mathrm{COVm}$, d) Correlação $\mathrm{PBCH}_{4}$ vs DQO afluente.

Observa-se na relação entre $\mathrm{PBCH}_{4}$ e o pH efluente (Figura 44a) correlação negativa foi obtida, em que as maiores produções de metano $\left(5,94\right.$ - 5,09 $\left.\mathrm{LCH}_{4}\right)$ ocorreram em $\mathrm{pH}$ com valores entre 8,0 e 8,5 .

Para verificar a estabilidade da manutenção da metanogênese foi obtido o coeficiente de correlação entre a produção de metano e a relação AI/AP (Figura 44b). Observou-se que houve correlação nula, isto indica que o reator se adaptou as diferentes cargas impostas, manteve-se a produção de metano mesmo em valores discrepantes da média da relação AI/AP, o que confirmou a hipótese de estabilidade do processo metanogênico no segundo reator. 
Para certificar a resiliência do reator, o coeficiente de correlação entre $\mathrm{PBCH}_{4}$ e a COVm (Figura 44c) apontaram que a produção de metano aumentou conforme houve incremento da COVm, no entanto em cargas elevadas acima de $20 \mathrm{gDQO} . \mathrm{Lr}^{-1}$. $\mathrm{dia}^{-1}$ houve o decaimento da produção de metano. Esses dados indicam efeitos inibitórios em relação a sobrecarga a que foi exposto o reator.

O efeito inibitório da sobrecarga foi reafirmado pela correlação entre $\mathrm{PBCH}_{4}$ e a DQO afluente (Figura 44d). Observou-se que as maiores produções de metano ocorreram na faixa que compreende 7,5 e 12,5 g.DQO.L ${ }^{-1}$. Valores de DQO acima dos descritos permitiram manter a produção de $\mathrm{CH}_{4}$, mas com níveis abaixo do que na faixa relatada, verificando ligeiro decaimento conforme aumento da DQO Afluente.

Embora o controle do $\mathrm{pH}$ afluente com a adição de $\mathrm{NaHCO}_{3}$ tenha exercido fator-chave para o estabelecimento da metanogênese, observa-se que a comunidade metanogênica se adaptou favoravelmente a diminuição da dependência de álcali aplicada, mantendo as maiores produções de metano nos valores de $\mathrm{pH}$ indicados na correlação $\mathrm{PBCH}_{4}$ vs $\mathrm{pH}$ (Figura 44a).

Afirma-se com os resultados apresentados que a dependência de controle de pH externo pode ser gradativamente diminuída conforme a biomassa se adapta. Com isso pode-se diminuir custos em relação à manutenção da metanogênese em sistemas de duas fases com águas residuárias ácidas, mantendo a geração de alcalinidade conforme indica a correlação $\mathrm{PBCH}_{4} \mathrm{e}$ a relação AI/AP (Figura 44b).

Observa-se a resiliência e adaptação do reator quanto à variação de aumento de vazão e incremento de carga orgânica volumétrica aplicada (Figura 44c).

A hipótese é que a estimativa da produção de metano no processo anaeróbio baseia-se na concentração de matéria orgânica e na eficiência de sua remoção e conversão a metano. Para tanto, verificou-se que para o coeficiente de correlação entre $\mathrm{PBCH}_{4}$ e a DQO efluente (Figura 45a), a qual foi observado correlação nula $(P=0)$, visto que a produção de $\mathrm{CH}_{4}$ ocorreu em várias faixas de remoção de DQO (0,84-3,94gDQO.L ${ }^{-1}$ efluente), indicando que independentemente da quantidade de DQO removida houve produção de metano.

No entanto para o coeficiente de correlação entre $\mathrm{PBCH}_{4}$ e a \% de DQO Removida (Figura 45b), observa-se que as maiores produções de metano ocorreram entre valores próximos a $80 \%$ (entre 75 e $85 \%$ ) de remoção de DQO. 


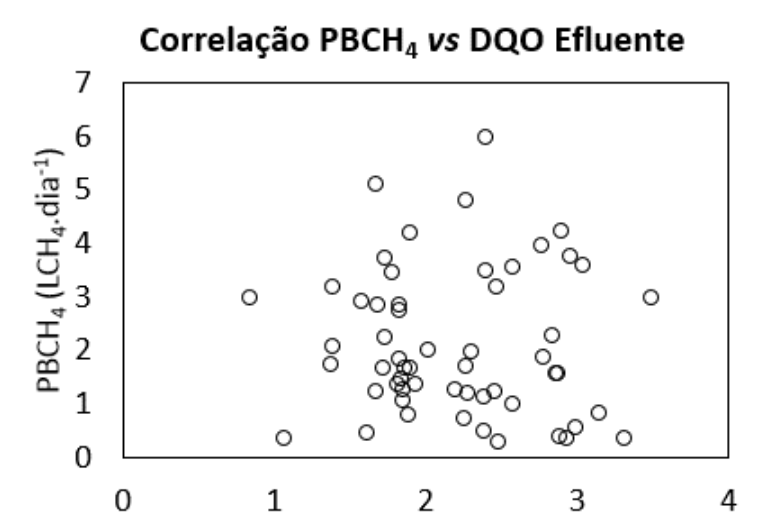

a)

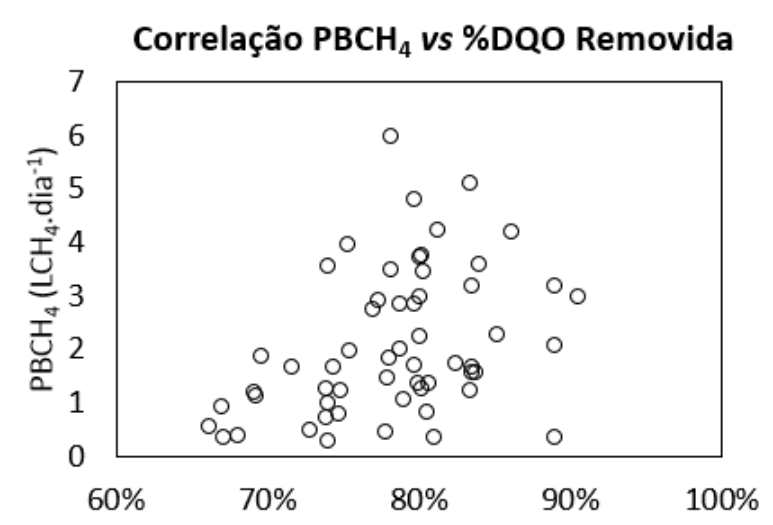

b)

Figura 45: Coeficiente de correlação entre $\mathrm{PBCH}_{4}$ e os valores de DQO efluentes obtidos; a) $\mathrm{PBCH}_{4} v s$ DQO efluente, b) $\mathrm{PBCH}_{4} v s \%$ de DQO removida.

Como observado na Figura 46a, o rendimento de metano por grama de DQO removida $\left(\mathrm{YCH}_{4}\right)$ expresso em $\mathrm{mLCH}_{4} . \mathrm{gDQOremovida}{ }^{-1}$, apresentou comportamento diferente das produções bruta $\left(\mathrm{PBCH}_{4}\right)$ e volumétrica $\left(\mathrm{PVCH}_{4}\right)$ de metano, em que nas maiores cargas aplicadas houve os menores rendimentos de metano.

$\mathrm{Na}$ Figura 46b conforme o aporte de nutrientes pelo aumento da COVm a partir da Fase III ( 5 gDQO. $\mathrm{Lr}^{-1} \cdot \mathrm{dia}^{-1}$ e TDH de 48h), houve decréscimo do rendimento de metano por grama de DQO removida. Observam-se valores praticamente nulos na Fase VI (26 gDQO.Lr ${ }^{-1} \cdot \mathrm{dia}^{-1} \mathrm{e}$ TDH de 16h), retomando o rendimento na Fase VII (17,5 gDQO.Lr ${ }^{-1} \cdot \mathrm{dia}^{-1}$ e TDH de 12h). Embora ainda mantivesse a produção de metano e remoção de DQO em todas as fases.
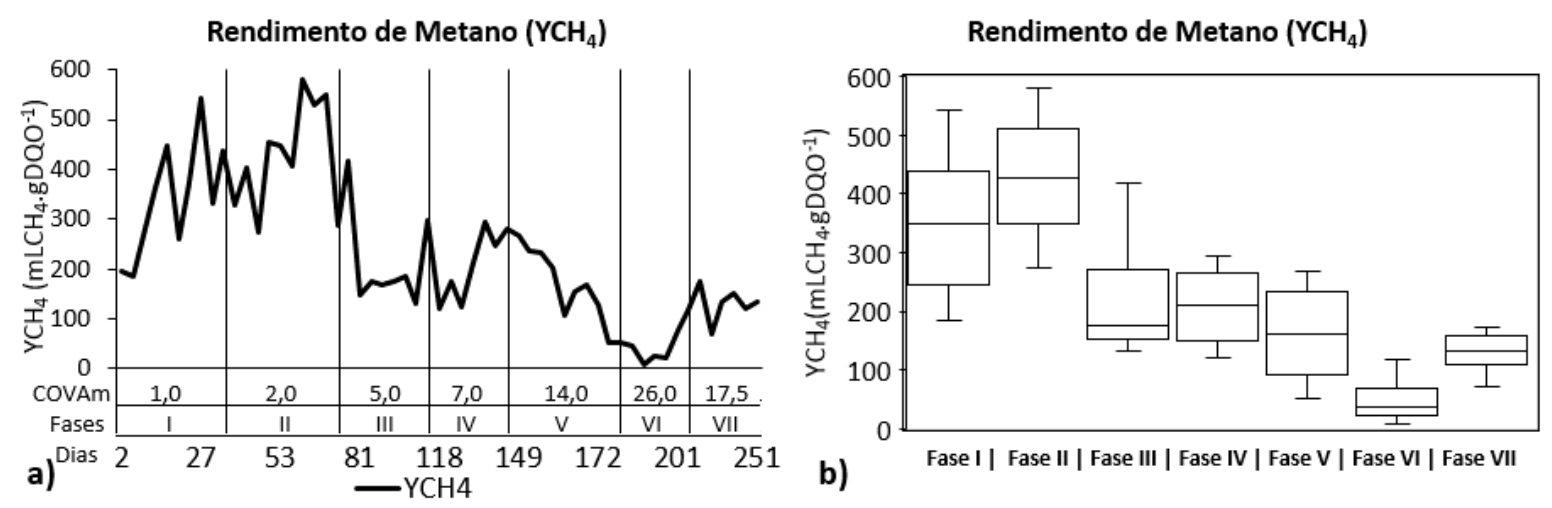

Figura 46: Monitoramento do rendimento de metano por gDQO removida $\left(\mathrm{YCH}_{4}\right)$; a) Monitoramento temporal do rendimento de metano gDQO removida $\left(\mathrm{YCH}_{4}\right)$, b) análise estatística de boxplot do rendimento de metano gDQO removida $\left(\mathrm{YCH}_{4}\right)$. 
$\mathrm{Na}$ Figura $47 \mathrm{a}$ o rendimento de metano por quilograma de melaço $\left(\mathrm{ZCH}_{4}\right)$ expresso em $\mathrm{LCH}_{4} \cdot \mathrm{kgmelaço}^{-1}$, apresentou comportamento semelhante ao rendimento anterior $\left(\mathrm{YCH}_{4}\right)$, visto o decaimento do rendimento em cargas elevadas indicando inibição da metanogênese em altas cargas.

$\mathrm{Na}$ análise de boxplot da Figura 47b observa-se que o maior rendimento ocorreu na Fase II (2gDQO.Lr ${ }^{-1} \cdot$ dia $^{-1}$ e TDH de 96h) com média de 631,3 \pm 168 LCH $_{4} \cdot$ kgmelaço $^{-1}$. A partir desta fase o rendimento de metano foi decaindo para as fases subsequentes, com acentuado decréscimo para a Fase VI. No entanto, o rendimento retomou o crescimento na Fase VII $(17,5$ gDQO.Lr ${ }^{-1} \cdot \operatorname{dia}^{-1}$ e TDH de 12h).
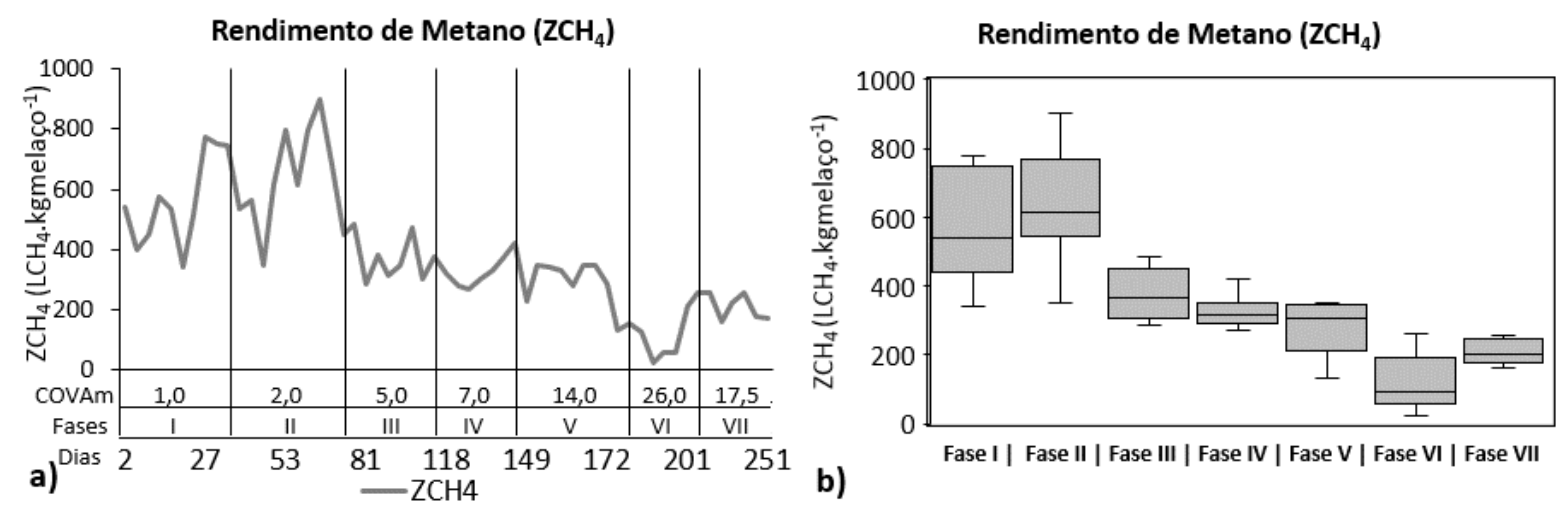

Figura 47: Monitoramento do rendimento de metano por $\mathrm{kg}$ de melaço $\left(\mathrm{ZCH}_{4}\right)$; a) Monitoramento temporal do rendimento de metano por $\mathrm{kg}$ de melaço $\left(\mathrm{ZCH}_{4}\right)$, b) análise estatística de boxplot do rendimento de metano por kg de melaço $\left(\mathrm{ZCH}_{4}\right)$.

Com os resultados obtidos nesta etapa pode-se afirmar que houve desequilíbrio do sistema metanogênico creditado ao aumento da COVm.

Comparando os resultados obtidos em todas as fases estudadas afirma-se que a Fase V com COVm de 14 gDQO. $\mathrm{Lr}^{-1} \cdot \mathrm{dia}^{-1}$, TDH de 34h apontou resultados mais satisfatórios para a produção de metano com eficiência na remoção de DQO em águas com elevada taxa de acidificação.

Vários relatos na literatura pertinentes (ANTONOPOULOU et al., 2010; LEE et al., 2010) apontam que o pH de crescimento ótimo das bactérias acetogênicas e arquéias metanogênicas em sistemas combinados de dois estágios está na faixa de $\mathrm{pH}$ compreendida de $7-8$, para sistemas com condição mesofílica $\left(35-42^{\circ} \mathrm{C}\right)$. No entanto para o presente estudo com condição termofílica $\left(55^{\circ} \mathrm{C}\right)$, observou-se crescimento otimizado em faixa de $\mathrm{pH}$ compreendida 8-8,5, faixa com maior produção de metano. 
128

Considerando que o processo de remoção de DQO apresentou eficiência média acima de $70 \%$, pode-se afirmar com estes resultados a robustez do reator metanogênico aplicado em condições de águas residuárias com elevada concentração de ácidos e consequente baixos valores de $\mathrm{pH}$.

Houve a necessidade da correção inicial do pH para estabelecimento da metanogênese, embora os organismos se adaptaram a diminuição da correção com álcali, mantendo a geração de alcalinidade e relação AI/AP estáveis.

Esta investigação demonstrou claramente que substratos provenientes de águas residuárias com elevada concentração de ácidos para a produção continua de hidrogênio, podem ser utilizados para a produção de metano e consequente estabilização e remoção da matéria orgânica, pela eficiência elevada de remoção de DQO em sistemas de duas fases, aplicando estratégias simples de controle de $\mathrm{pH}$ afluente e mantendo a concentração de matéria orgânica estável.

A Tabela 25 aponta a visão geral do desempenho do reator metanogênico frente às variáveis aplicadas e as produções de $\mathrm{CH}_{4}$ obtidas. 
Tabela 25: Visão geral do desempenho do reator metanogênico

\begin{tabular}{|c|c|c|c|c|c|c|c|c|}
\hline \multirow{2}{*}{ Variáveis } & & \multicolumn{7}{|c|}{ Desempenho Reator Metanogênico por Fases } \\
\hline & & $\mathbf{I}$ & II & III & IV & $\mathbf{V}$ & VI & VII \\
\hline \multirow{4}{*}{ pH Afluente } & Média & 7,48 & 7,22 & 7,07 & 6,83 & 6,57 & 6,28 & 6,56 \\
\hline & Máximo & 8,15 & 7,34 & 7,33 & 6,99 & 7,02 & 6,57 & 6,78 \\
\hline & Mínimo & 7,19 & 7,07 & 6,69 & 6,68 & 6,20 & 5,55 & 6,34 \\
\hline & Desvio & $\pm 0,26$ & $\pm 0,09$ & $\pm 0,20$ & $\pm 0,11$ & $\pm 0,27$ & $\pm 0,37$ & $\pm 0,18$ \\
\hline \multirow{4}{*}{ pH Efluente } & Média & 9,20 & 9,00 & 8,53 & 8,51 & 8,47 & 8,43 & 8,32 \\
\hline & Máximo & 9,60 & 9,15 & 8,63 & 8,70 & 8,86 & 8,61 & 8,45 \\
\hline & Mínimo & 8,99 & 8,85 & 8,31 & 8,27 & 8,30 & 8,19 & 8,15 \\
\hline & Desvio & $\pm 0,18$ & $\pm 0,10$ & $\pm 0,11$ & $\pm 0,15$ & $\pm 0,15$ & \pm 0.14 & $\pm 0,11$ \\
\hline \multirow{4}{*}{$\begin{array}{l}\text { DQO Afluente } \\
\left(\mathrm{gDQO} . \mathrm{L}^{-1}\right)\end{array}$} & Média & 8,61 & 8,77 & 9,35 & 9,32 & 13,69 & 17,24 & 10,65 \\
\hline & Máximo & 9,78 & 10,14 & 11,26 & 12,74 & 17,73 & 19,36 & 12,74 \\
\hline & Mínimo & 6,59 & 7,45 & 7,47 & 7,93 & 7,03 & 13,79 & 8,73 \\
\hline & Desvio & $\pm 0,98$ & $\pm 0,99$ & $\pm 1,10$ & $\pm 1,74$ & $\pm 3,81$ & $\pm 2,05$ & $\pm 1,36$ \\
\hline \multirow{4}{*}{$\begin{array}{l}\text { DQO Efluente } \\
\left(\mathrm{gDQO} . \mathrm{L}^{-1}\right)\end{array}$} & Média & 2,24 & 2,19 & 2,01 & 1,52 & 2,62 & 3,34 & 2,01 \\
\hline & Máximo & 3,00 & 2,78 & 2,59 & 1,84 & 3,50 & 5,78 & 2,59 \\
\hline & Mínimo & 1,07 & 1,68 & 1,82 & 0,85 & 1,59 & 1,91 & 1,40 \\
\hline & Desvio & $\pm 0,63$ & $\pm 0,33$ & $\pm 0,28$ & $\pm 0,35$ & $\pm 0,57$ & $\pm 1,29$ & $\pm 0,47$ \\
\hline \multirow{4}{*}{$\begin{array}{l}\text { Remoção de DQO } \\
\left(\text { gDQO.L }{ }^{-1}\right)\end{array}$} & Média & 6,38 & 6,59 & 7,34 & 7,80 & 11,07 & 13,90 & 8,63 \\
\hline & Máximo & 8,71 & 8,46 & 8,98 & 11,35 & 14,85 & 16,51 & 11,35 \\
\hline & Mínimo & 4,72 & 5,16 & 5,56 & 6,16 & 5,44 & 11,74 & 6,99 \\
\hline & Desvio & $\pm 1,03$ & $\pm 1,05$ & $\pm 0,96$ & $\pm 1,81$ & $\pm 3,33$ & $\pm 2,04$ & $\pm 1,53$ \\
\hline \multirow{4}{*}{$\begin{array}{l}\text { \% Remoção de } \\
\text { DQO }\end{array}$} & Média & $73,9 \%$ & $74,8 \%$ & $78,4 \%$ & $83,2 \%$ & $80,4 \%$ & $80,7 \%$ & $80,8 \%$ \\
\hline & Máximo & $89,0 \%$ & $83,4 \%$ & $80,7 \%$ & $90,5 \%$ & $83,8 \%$ & $86,2 \%$ & $89,0 \%$ \\
\hline & Mínimo & $66,3 \%$ & $69,3 \%$ & $74,1 \%$ & $77,0 \%$ & $75,3 \%$ & $67,0 \%$ & $74,1 \%$ \\
\hline & Desvio & $\pm 6,7 \%$ & $\pm 4,6 \%$ & $\pm 2,6 \%$ & $\pm 5,0 \%$ & $\pm 2,8 \%$ & $\pm 7,1 \%$ & $\pm 5,1 \%$ \\
\hline \multirow{4}{*}{ Relação AI/AP } & Média & 0,58 & 0,53 & 0,58 & 0,57 & 0,50 & 0,48 & 0,49 \\
\hline & Máximo & 0,73 & 0,60 & 0,83 & 068 & 0,63 & 0,56 & 0,53 \\
\hline & Mínimo & 0,47 & 0,43 & 0,44 & 0,53 & 0,44 & 0,31 & 0,45 \\
\hline & Desvio & $\pm 0,07$ & $\pm 0,06$ & $\pm 0,12$ & $\pm 0,05$ & $\pm 0,06$ & $\pm 0,10$ & $\pm 0,03$ \\
\hline \multirow{4}{*}{$\begin{array}{l}\mathrm{PBCH}_{4} \\
\left(\mathrm{LCH}_{4} \cdot \mathrm{dia}^{-1}\right)\end{array}$} & Média & 0,68 & 1,39 & 1,51 & 2,29 & 3,08 & 2,00 & 4,37 \\
\hline & Máximo & 1,80 & 1,98 & 2,83 & 2,97 & 4,19 & 4,18 & 5,94 \\
\hline & Mínimo & 0,26 & 0,77 & 0,97 & 1,63 & 1,53 & 0,33 & 3,17 \\
\hline & Desvio & $\pm 0,56$ & $\pm 0,40$ & $\pm 0,59$ & $\pm 0,54$ & $\pm 0,91$ & $\pm 1,60$ & $\pm 1,60$ \\
\hline \multirow{4}{*}{$\begin{array}{l}\mathrm{PVCH}_{4} \\
\left(\mathrm{LCH}_{4} \cdot \mathrm{Lr}^{-1} \cdot \mathrm{dia}^{-1}\right)\end{array}$} & Média & 0,41 & 0,84 & 0,91 & 1,39 & 1,87 & 1,21 & 2,65 \\
\hline & Máximo & 1,09 & 1,20 & 1,72 & 1,80 & 2,54 & 2,54 & 3,60 \\
\hline & Mínimo & 0,16 & 0,46 & 0,59 & 0,99 & 0,93 & 0,20 & 1,92 \\
\hline & Desvio & $\pm 0,01$ & $\pm 0,25$ & $\pm 0,36$ & $\pm 0,33$ & $\pm 0,55$ & $\pm 0,97$ & $\pm 0,65$ \\
\hline \multirow{4}{*}{$\begin{array}{l}\mathrm{YCH}_{4} \\
\left(\mathrm{mLCH}_{4} \cdot \mathrm{DQOrem}^{-1}\right)\end{array}$} & Média & 342 & 426 & 212 & 207 & 160 & 48 & 130 \\
\hline & Máximo & 544 & 581 & 417 & 294 & 268 & 118 & 173 \\
\hline & Mínimo & 185 & 275 & 132 & 121 & 52 & 7 & 70 \\
\hline & Desvio & \pm 114 & \pm 107 & \pm 96 & \pm 70 & \pm 75 & \pm 41 & \pm 34 \\
\hline \multirow{4}{*}{$\begin{array}{l}\mathrm{ZCH}_{4} \\
\left(\mathrm{LCH}_{4} \cdot \mathrm{kgmelaço}^{-1}\right)\end{array}$} & Média & 563,4 & 631,3 & 371,2 & 328,3 & 281 & 124,1 & 209,2 \\
\hline & Máximo & 775,6 & 899,6 & 484,5 & 420,7 & 351 & 260,7 & 258,1 \\
\hline & Mínimo & 341,6 & 348,6 & 288,1 & 271 & 131,9 & 23,6 & 160,9 \\
\hline & Desvio & $\pm 150,7$ & \pm 168 & $\pm 74,6$ & \pm 53 & $\pm 81,7$ & $\pm 95,5$ & $\pm 42,9$ \\
\hline
\end{tabular}


5.2.3 Avaliação dos Ácidos Orgânicos Voláteis no Sistema de Reatores Combinados

A verificação das possíveis rotas de degradação que ocorrem nos processos de conversão da matéria orgânica pode ser efetuada pela análise dos componentes (ácidos, álcoois, etc.) do afluente e efluente dos reatores, além do conteúdo de matéria orgânica (DQO) utilizado nas avaliações de desempenho.

A compreensão dessas rotas de degradação permite o entendimento dos bioprocessos como sistemas complexos, envolvendo a ecologia dos reatores anaeróbios, suas inter-relações funcionais, possibilitando a adoção de estratégias em função dos produtos desejados: gases combustíveis, ácidos orgânicos, etc.

A partir dos resultados obtidos pela análise de ácidos orgânicos voláteis é apresentada na Tabela 26, a caracterização da matéria orgânica do afluente do biorreator em termos de ácidos orgânicos voláteis (AOV).

Tabela 26: DQO relativa dos ácidos orgânicos voláteis no afluente

\begin{tabular}{lccc}
\hline Ácidos Orgânicos Voláteis & $\begin{array}{c}\text { DQO } \\
\text { Relativa* } \\
\left(\text { mgDQO.L }^{-1}\right)\end{array}$ & $\begin{array}{c}\text { Concentração } \\
\text { Média na água } \\
\text { residuária }\left(\mathbf{m g . L}^{-\mathbf{1}}\right)\end{array}$ & $\begin{array}{c}\text { Concentração } \\
\text { Relativa }\left(\mathbf{m g . L}^{-\mathbf{1}}\right) \\
\text { a ácido acético }\end{array}$ \\
\hline Ácido Ć́trico $\left(\mathrm{C}_{6} \mathrm{H}_{8} \mathrm{O}_{7}\right)$ & 0,666 & 360 & 240 \\
Ácido Málico $\left(\mathrm{C}_{4} \mathrm{H}_{6} \mathrm{O}_{5}\right)$ & 0,716 & 330 & 235 \\
Ácido Succínico $\left(\mathrm{C}_{4} \mathrm{H}_{6} \mathrm{O}_{4}\right)$ & 0,948 & 400 & 380 \\
Ácido Lático $\left(\mathrm{C}_{3} \mathrm{H}_{6} \mathrm{O}_{3}\right)$ & 1,066 & 229 & 240 \\
Ácido Fórmico $\left(\mathrm{CH}_{2} \mathrm{O}_{2}\right)$ & 0,348 & 228 & 80 \\
Ácido Acético $\left(\mathrm{C}_{2} \mathrm{H}_{4} \mathrm{O}_{2}\right)$ & 1,066 & 277 & 295 \\
Ácido Propiônico $\left(\mathrm{C}_{3} \mathrm{H}_{6} \mathrm{O}_{2}\right)$ & 1,512 & 170 & 255 \\
Ácido Butírico $\left(\mathrm{C}_{4} \mathrm{H}_{8} \mathrm{O}_{2}\right)$ & 1,816 & 18 & 35 \\
\hline
\end{tabular}

*DQO relativa é a determinação por análise de DQO de solução de $1 \mathrm{~L}$ contendo $1 \mathrm{mg}$ da substância em questão.

Os perfis de concentração espacial dos ácidos orgânicos voláteis no afluente é apresentado pela análise estatística de boxplot na Figura 48. 


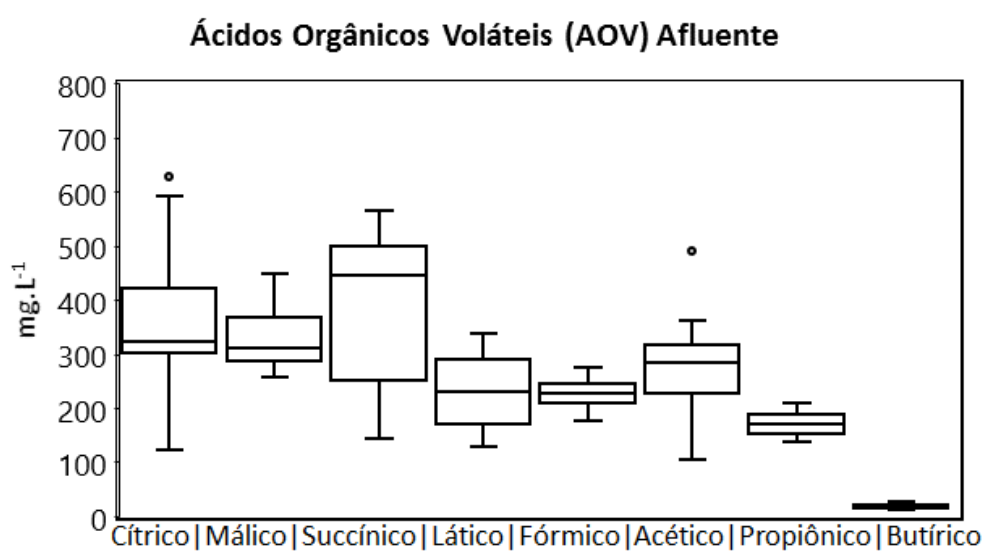

Figura 48: Análise estatística de boxplot dos ácidos orgânicos voláteis (AOV) afluente

A partir dos dados obtidos no afluente (Figura 48), pode-se fazer o comparativo da geração de ácidos no efluente dos reatores, a qual se pode descrever as possíveis rotas metabólicas e o entendimento da ecologia do sistema de reatores em série como sistema interrelacionados.

As equações 33 a 35 (consolidadas pela literatura pertinente) e equações 36 e 37 (via ácido lático) representam as possíveis rotas de digestão ácida em reator acidogênico para a produção e consumo de hidrogênio.

Produção de Ácido Acético (Rota de produção de hidrogênio)

$\mathrm{C}_{6} \mathrm{H}_{12} \mathrm{O}_{6}+2 \mathrm{H}_{2} \mathrm{O} \rightarrow 2$ Acético $+2 \mathrm{CO}_{2}+4 \mathrm{H}_{2}$

Equação 32

Produção de Ácido Butírico (Rota de produção de hidrogênio)

$\mathrm{C}_{6} \mathrm{H}_{12} \mathrm{O}_{6} \rightarrow$ Butírico $+2 \mathrm{CO}_{2}+2 \mathrm{H}_{2}$

Equação 33

Produção de Ácido Propiônico (Rota de consumo de hidrogênio)

$\mathrm{C}_{6} \mathrm{H}_{12} \mathrm{O}_{6}+2 \mathrm{H}_{2} \rightarrow$ Propiônico $+2 \mathrm{H}_{2} \mathrm{O}$

Equação 34

No presente estudo foi possível observar uma relação clara entre a produção de hidrogênio e a concentração dos produtos intermediários (Figura 49). Observou-se que as rotas metabólicas preferenciais da produção de hidrogênio no reator acidogênico foram as vias dos ácidos butírico e lático sem acúmulo de ácido propiônico, explicando a manutenção da produção continua de hidrogênio, conforme as equações apresentadas. 


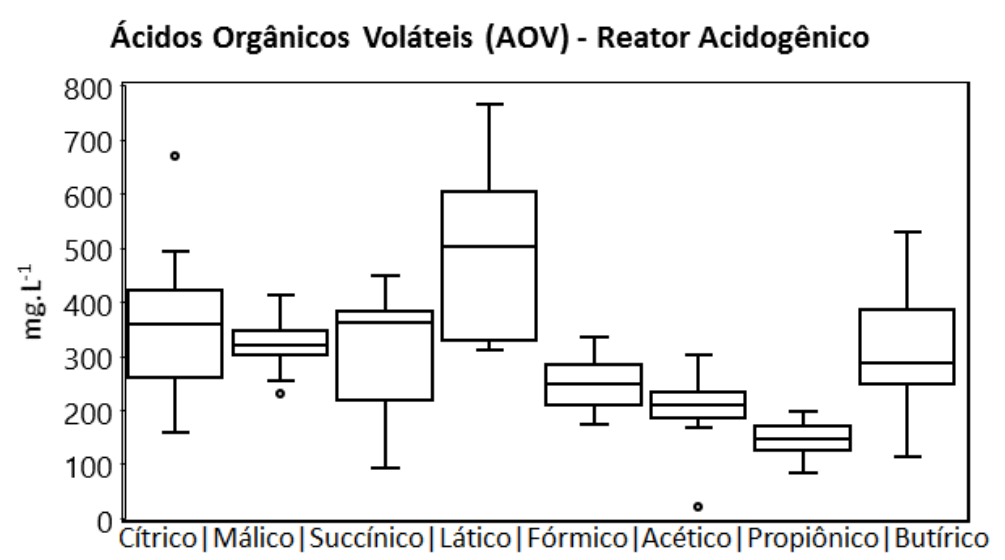

Figura 49: Análise estatística de boxplot produtos intermediários gerados no reator acidogênico.

Como observado nas equações 33 a 35, comparando as rotas de produção/consumo de $\mathrm{H}_{2}$, a rota do ácido acético está associada ao maior rendimento de produção de hidrogênio. No entanto, na prática, elevados rendimentos de $\mathrm{H}_{2}$ são obtidos quando se observa a produção da mistura dos ácidos acético e butírico, como produtos da fermentação anaeróbia (LEVIN et al. 2004), além da associação com o ácido lático como observado no presente estudo.

Ohnishi et al. (2012) descreveram a fermentação para produção de $\mathrm{H}_{2}$ usando lactato como única fonte de carbono, ou seja, não houve produção de ácido lático, o ácido foi adicionado previamente. $\mathrm{O}$ rendimento de hidrogênio obtido via bactérias produtoras de hidrogênio da espécie Megasphaera elsdenii foi de aproximadamente 0,4 $\mathrm{molH}_{2} \cdot \mathrm{mol}^{-1}$ lactato. A qual os autores propuseram a equação do tipo:

2 Lactato $\rightarrow$ Acetato + Propionato $+\mathrm{CO}_{2}+\mathrm{H}_{2}$ Equação 35

Masset et al. (2012) apresentaram modelo simplificado das principais vias metabólicas envolvidas na produção de $\mathrm{H}_{2}$ por Clostridium spp. a partir da glicose via Piruvato.

Os autores descreveram a rota da produção de $\mathrm{H}_{2}$ via ácido lático (com produção deste ácido) acoplada a rota proposta por Matsumoto et al. (2007), de acordo com a Equação 36.

$\left(\mathrm{C}_{6} \mathrm{H}_{12} \mathrm{O}_{6} \rightarrow \text { Lactato }+ \text { Acetato }\right)^{*} \rightarrow\left(\text { Butirato }+\mathrm{CO}_{2}+\mathrm{H}_{2}\right)^{* *}$

()* Via metabólica adaptada de Masset et al. (2012)

()** Via metabólica proposta por Matsumoto et al. (2007) 
Observa-se na rota apresentada por Masset et al. (2012) a associação de ácidos produtores de hidrogênio relatados na literatura pertinente (acético e butírico), com a produção de ácido Lático via Piruvato a partir da Glicose (Figura 50).

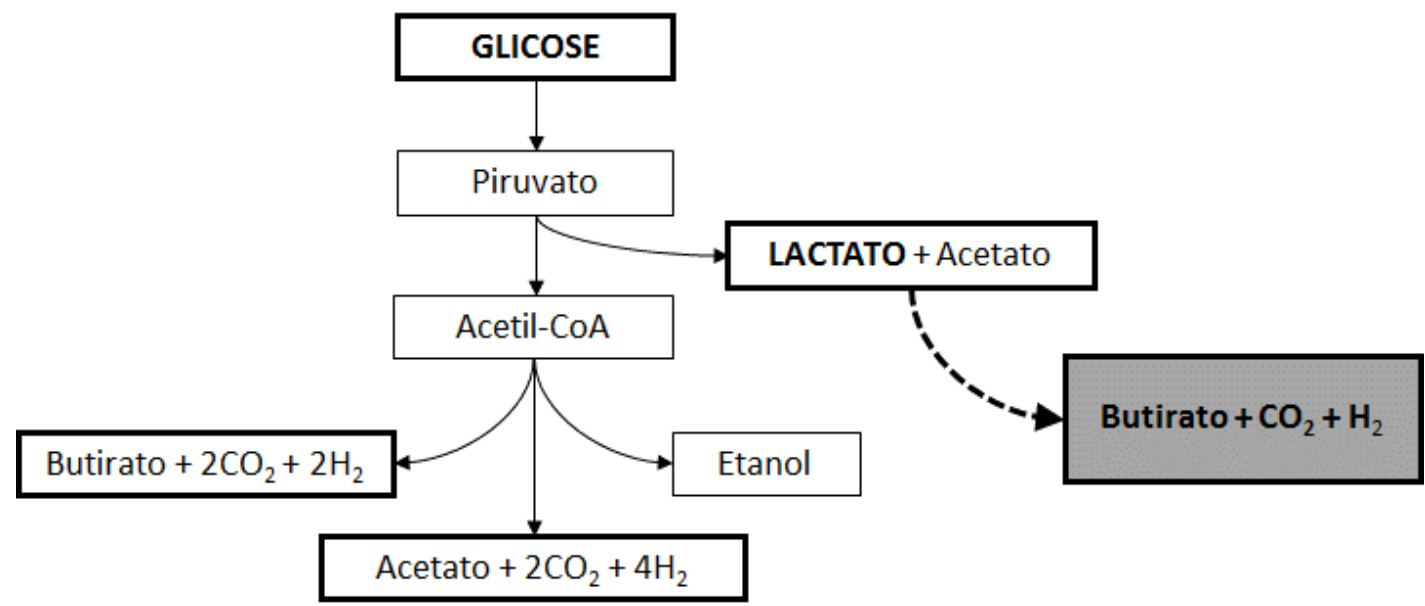

Figura 50: Visão simplificada das principais rotas metabólicas envolvendo a produção de $\mathrm{H}_{2}$ por Clostridium spp.

Adaptada de Masset et al. (2012).

A linha tracejada indica a rota teórica da produção de $\mathrm{H}_{2}$ pela via do Lactato proposta por Matsumoto et al. (2007).

Em ambas as rotas metabólicas apresentadas via ácido Lático para a produção de $\mathrm{H}_{2}$ (Equação 35 e Equação 36) pode-se observar a presença dos ácidos relatados anteriormente para produção e consumo de $\mathrm{H}_{2}$ (acético, butírico -produção- e propiônico -consumo-). Outro dado importante é que nos trabalhos relatados, os organismos produtores de hidrogênio eram isolados, o que não aconteceu para este estudo em que se utilizou inóculo de reator anaeróbio, com elevada diversidade microbiana.

Acredita-se que a produção contínua de $\mathrm{H}_{2}$ obtida nos resultados deste estudo está relacionada à associação das rotas metabólicas dos ácidos produtores de hidrogênio, já consolidados pela literatura pertinente (acético e butírico) e pela produção de hidrogênio pela rota do ácido lático.

A rota mais provável de produção de $\mathrm{H}_{2}$ pela via do ácido lático ocorrida neste estudo seja a proposta por Matsumoto et al. (2007) complementada por Masset et al. (2012), visto a presença dos ácidos produtores de $\mathrm{H}_{2}$ e o não acumulo de ácido propiônico (consumidor de $\mathrm{H}_{2}$ ). Os dados relacionados apontam que a diversidade microbiana auxiliou na manutenção da produção de hidrogênio por rotas metabólicas coexistentes no reator. 
Para o reator metanogênico optou-se por apresentar os dados obtidos dos ácidos orgânicos voláteis (AOV) em conformidade com os gráficos de rendimento de metano analisados anteriormente (conforme aponta os resultados do capítulo anterior, Figura 46 e Figura 47).

Nos resultados apresentados de rendimento de $\mathrm{CH}_{4}$ elevados, os dados de AOV foram agrupados nas Fases I e II (Figura 51a); nos resultados apresentados de rendimento de $\mathrm{CH}_{4}$ intermediários, os dados de AOV foram agrupados nas Fases III, IV e V (Figura 51b); nos resultados de rendimentos de $\mathrm{CH}_{4}$ inferiores, os dados de AOV foram agrupados nas Fases VI e VII (Figura 51c).

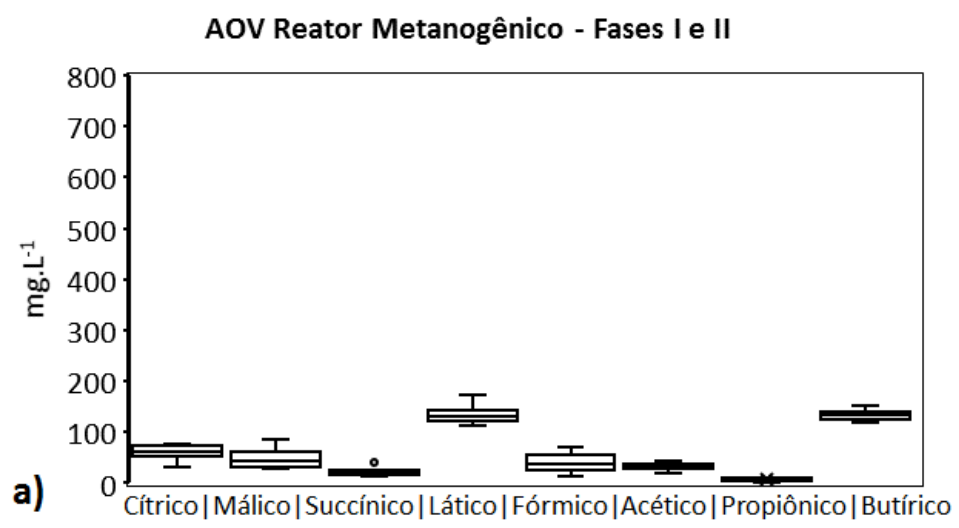

AOV Reator Metanogênico - Fases III, IV e V

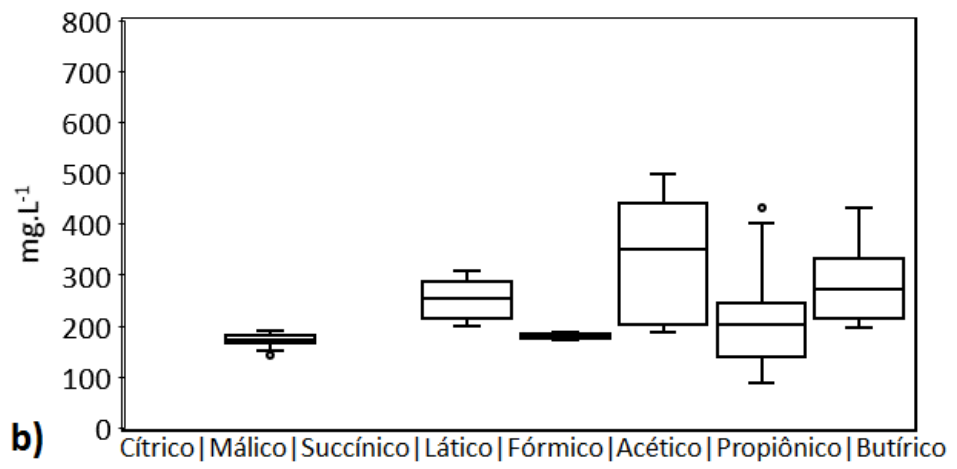

AOV Reator Metanogênico - Fases VI e VII

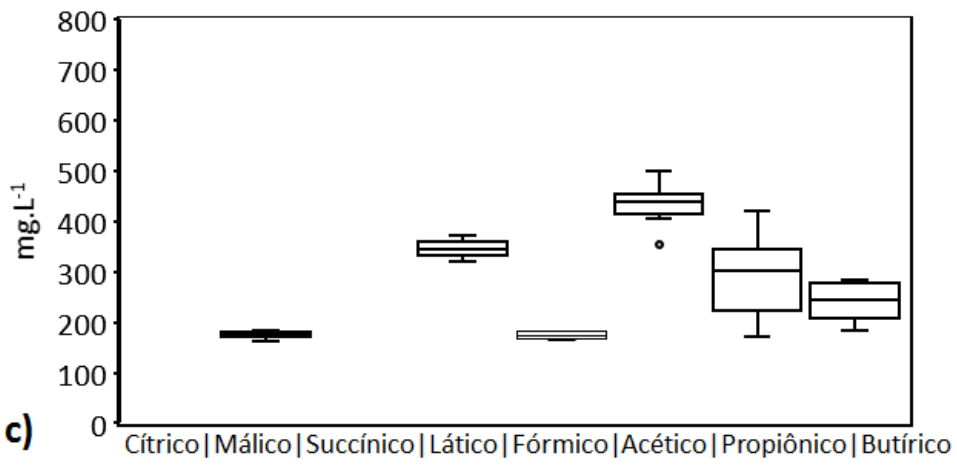

Figura 51: Produtos intermediários efluente reator metanogênico - Ácidos Orgânicos Voláteis (AOV) a) AOV Fases I e II, b) AOV Fases III, IV e V, c) AOV Fases VI e VII. 
No processo de degradação anaeróbia, um parâmetro importante para avalição do equilíbrio do sistema é a concentração de ácidos orgânicos voláteis. Quando o sistema está em equilíbrio, as arquéias metanogênicas usam os ácidos intermediários tão rapidamente quanto eles são fornecidos. Entretanto, se as metanogênicas não estão presentes em quantidades suficientes por alguma condição ambiental desfavorável, há o aumento na concentração de ácidos voláteis.

Este comportamento citado é observado no reator metanogênico para o presente estudo (conforme apontam os resultados do capítulo anterior, Figura 46 e Figura 47), nas Fases I e II de rendimento de metano elevados, não houve acúmulo de ácidos orgânicos voláteis no sistema. Para as Fases III, IV e V houve acúmulo perceptível (aumento da concentração) de ácidos acético, butírico, lático e propiônico. De tal modo que para as Fases VI e VII o acúmulo dos ácidos acético e propiônico se intensificou.

Os resultados obtidos nas análises de ácidos orgânicos acumulados para o reator metanogênico creditam ao aumento de carga a que foram expostos os microrganismos, embora o reator manteve o $\mathrm{pH}$ efluente estável, gerando alcalinidade e removendo DQO. 
136

\subsubsection{Abordagem Geral do Sistema de Reatores Combinados}

No presente estudo foi demonstrado a operação por longo período de tempo do sistema de duas fases, produzindo continuamente hidrogênio e sequencialmente metano, a partir de melaço da cana-de-açúcar.

O sistema de duas fases, composto de um reator anaeróbio acidogênico acoplado sequencialmente a um reator anaeróbio acidogênico/metanogênico, ambos de leito fixo estruturado com fluxo ascendente, demonstrou robustez e bom desempenho durante todo o período de operação, com 471 dias para o reator acidogênico com Carga Orgânica Volumétrica Aplicada (COV) de 30 - 120 gDQO.Lreator ${ }^{-1} \cdot$ dia $^{-1}$; e 251 dias para o reator metanogênico com Carga Orgânica Volumétrica Aplicada (COVm) de 1-26 gDQO.Lreator ${ }^{-1} \cdot$ dia $^{-1}$.

O reator acidogênico produziu efetivamente e continuamente hidrogênio ao longo de todo o período operacional (417 dias), com valores médios de $3690 \pm 1530 \mathrm{mlH}_{2}$.dia ${ }^{-1}$, no entanto ocorreram alguns pontos de instabilidade. Houve produção de ácidos precursores como o acético, butírico, além da produção do ácido lático de interesse comercial, e não houve acúmulo de ácido propiônico, ao qual a literatura refere-se como consumidor de hidrogênio.

No segundo reator, os ácidos gerados na fase acidogênica e no próprio foram prontamente metabolizados pela comunidade microbiana estabelecida no reator para a produção de metano, com valores médios de 2030 $\pm 1380 \mathrm{mlCH}_{4} \cdot \mathrm{dia}^{-1}$. Nas etapas de aumento de carga orgânica volumétrica (aumento de vazão e diminuição de TDH), houve o acúmulo durante os primeiros dias de ácidos orgânicos, indicando instabilidade no processo metanogênico e decaimento da produção de gás. Entretanto, o desempenho estável era novamente alcançado em alguns dias de operação.

A média de remoção de matéria orgânica (DQO) global do sistema foi de aproximadamente $90 \%$, com a maior parte da DQO sendo removida pelo reator metanogênico com contribuição média de aproximadamente $80 \%$ de eficiência, e a contribuição da remoção de DQO do reator acidogênico foi média de aproximadamente $10 \%$ de eficiência.

Relatos na literatura pertinente sobre a produção contínua de hidrogênio por longo período de tempo via fermentação escura (enzimática) e geração de metano em um segundo reator acoplado ao primeiro usando melaço como fonte de carbono são escassos. Este estudo vem contribuir com a geração de conhecimento, afim de demonstrar a robustez do sistema de biorreatores em duas fases operados por longo período de tempo, com a produção contínua de 
hidrogênio e metano, a qual é extremamente crucial para a aplicação do processo como tecnologia anaeróbia nas biorrefinárias brasileiras.

Do ponto de vista ambiental o excesso de melaço, que não for usado na produção de açúcar e etanol, pode ser aproveitado no processo anaeróbio com potencial para ser usado na codigestão com a vinhaça da cana-de-açúcar (ALBANEZ, 2015) sem que haja prejuízo para o mercado consumidor do açúcar e do álcool, visto o potencial de geração de energia em forma de biogás do melaço apontado neste estudo.

Do ponto de vista econômico diante do cenário de crise energética que assola o país de tempos em tempos, esta medida visa diminuir custos energéticos e manter o biorreator nas usinas operando continuamente no período de entressafra da cana-de-açúcar, período este em que há escassez de vinhaça.

O fluxograma da Figura 52 reporta o processo produtivo do açúcar e álcool com a produção de bioenergia a partir da vinhaça, desviando parte do melaço para a codigestão a fim de manter o reator anaeróbio em operação continua na entressafra.

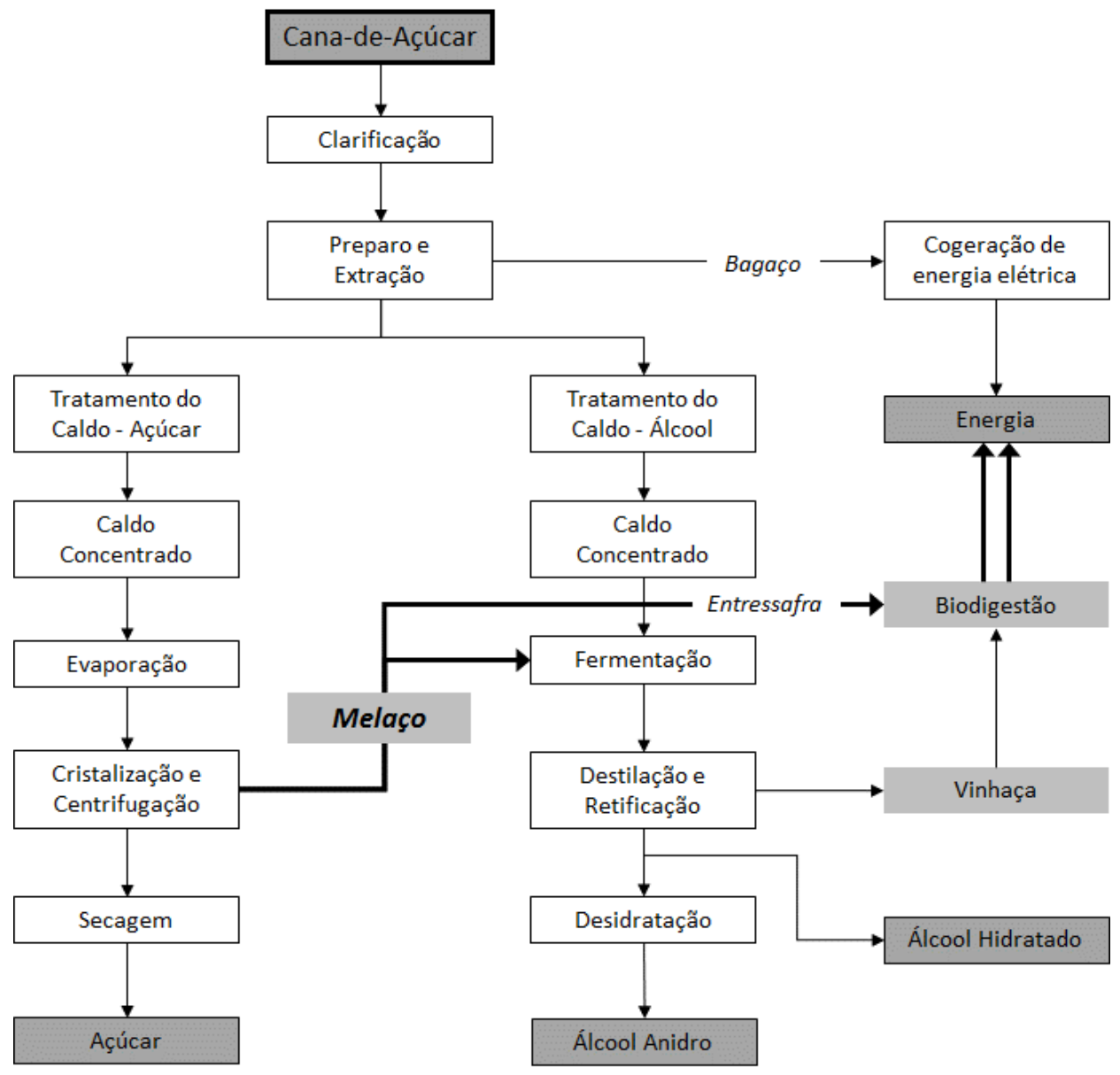

Figura 52: Fluxograma do processo produtivo do açúcar e álcool com a produção de bioenergia a partir da vinhaça, desviando parte do melaço para a codigestão a fim de manter o reator anaeróbio em operação continua na entressafra. 
138

Do ponto de vista científico e tecnológico este estudo deu mais um passo para a compreensão dos bioprocessos envolvidos nos sistemas anaeróbios em dois estágios produzindo hidrogênio e metano (biocombustíveis) continuamente e por longo período de tempo, usando o melaço de cana-de-açúcar como substrato.

Este trabalho permite afirmar que o sistema proposto se apresenta como uma alternativa viável para a produção biológica de $\mathrm{H}_{2}$ e $\mathrm{CH}_{4}$ a partir de matrizes orgânicas de elevada concentração. No entanto desafios precisam ser superados para otimizar a produção continua de hidrogênio e metano nos sistemas de reatores em dois estágios.

Adicionalmente, ao ponto de vista econômico ambiental, estudos futuros serão necessários e cruciais para a avaliação da inserção da digestão anaeróbia do melaço e outros subprodutos da cana-de-açúcar na matriz produtiva das biorrefinárias. Espera-se que o presente trabalho contribua com informações para o desenvolvimento de sistema para produção de biocombustíveis de maneira sustentável, com o uso e recuperação de fontes renováveis, com responsabilidades sociais e ambientais.

\subsubsection{Abordagem sobre o Balanço Energético do Sistema Combinado}

O hidrogênio e o metano, produzidos continuamente por longo período de tempo, têm grande potencial para serem usados como fontes energéticas limpas, renováveis e sustentáveis, após a limpeza e depuração dos gases $\left(\mathrm{H}_{2} \mathrm{e} \mathrm{CH}_{4}\right)$. Entretanto, uma análise econômica precisa ser realizada para verificação da viabilidade da implantação do processo.

Na avaliação econômica, deve ser avaliado o desvio de parte o melaço destinado para a geração de bioenergia pode ser bem aplicado dependendo das necessidades energéticas da matriz produtiva das biorrefinárias, o que também depende das condições de disponibilidade energética das concessionárias de energia elétrica.

Na Figura 53 apresentam-se dados calculados com base no presente trabalho, com respeito a utilização do melaço de cana-de-açúcar para a produção de hidrogênio e metano continuamente, usando reatores anaeróbios de leito fixo estruturado com fluxo ascendente em sistemas de duas fases em condições termofílicas $\left(55^{\circ} \mathrm{C}\right)$. 

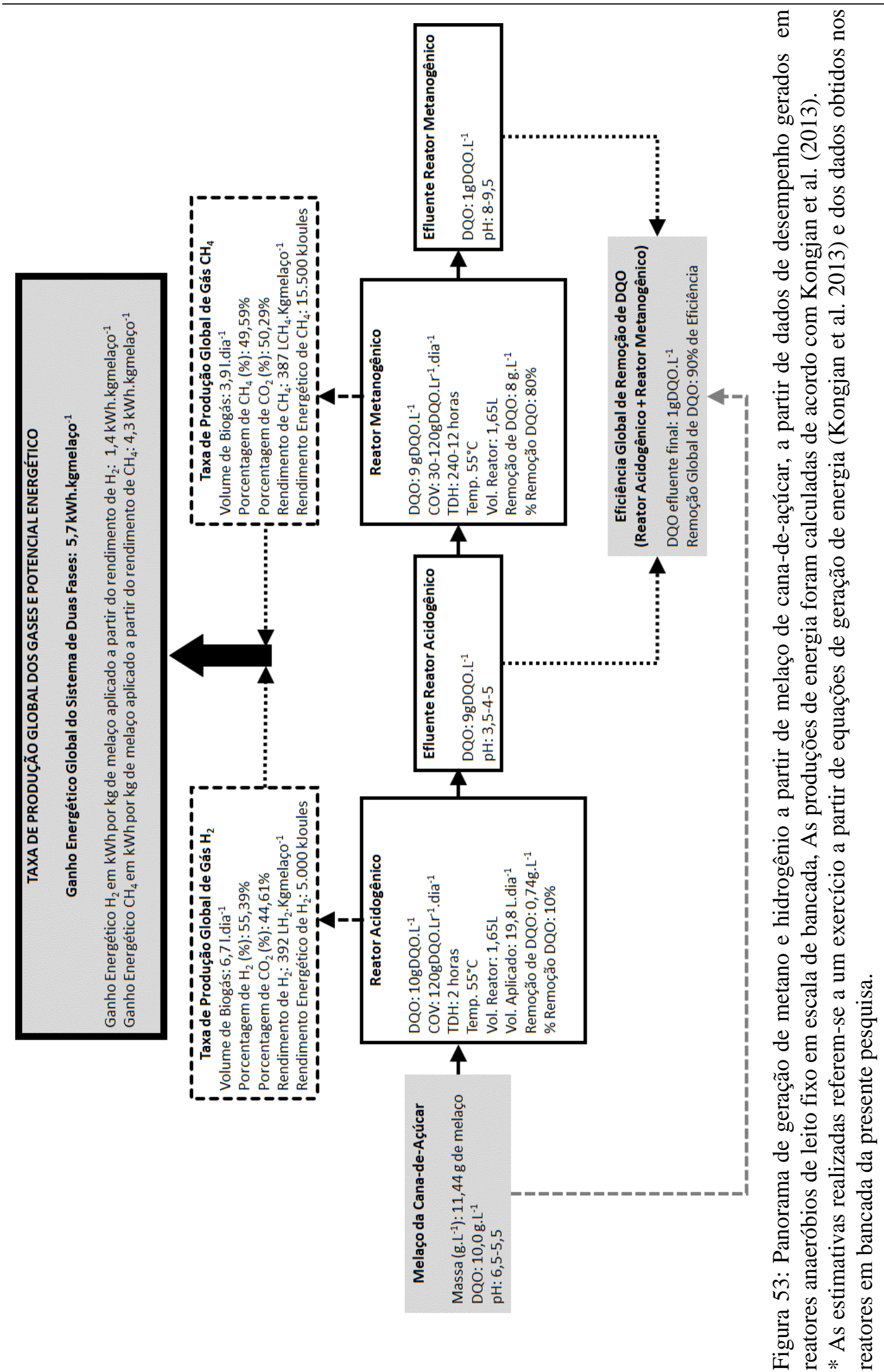
A partir do balanço energético exposto, o sistema de reatores em duas fases operado sob condição termofílica e alimentado com melaço da cana-de-açúcar, demonstrou que o conjunto dos reatores alcançou a remoção global de DQO de aproximadamente $90 \%$ de eficiência, como relatado anteriormente. A contribuição do reator acidogênico foi de aproximadamente $10 \%$ enquanto o reator metanogênico teve $80 \%$ de contribuição de eficiência, ou seja, dos 10gDQO. $\mathrm{L}^{-1}$ aplicados inicialmente ao experimento, 9gDQO. $\mathrm{L}^{-1}$ foram convertidos para a manutenção celular e geração de gases nos reatores.

O sistema de reatores de duas fases obteve volume de produção global da mistura de gases hidrogênio e metano de aproximadamente 5,6 L.dia ${ }^{-1}$ de biogás. A contribuição obtida pelo gás hidrogênio foi de aproximadamente $3,7 \mathrm{LH}_{2} \cdot \mathrm{dia}^{-1}$, e a contribuição obtida pelo gás metano foi de aproximadamente $1,9 \mathrm{LCH}_{4} \cdot \mathrm{dia}^{-1}$.

Pelo ponto de vista energético da aplicabilidade do melaço por massa $(\mathrm{kg})$, o reator acidogênico obteve rendimento de hidrogênio por quilo de melaço aplicado de 392 $\mathrm{LH}_{2} . \mathrm{Kgmelaço}^{-1}$, representando rendimento energético de aproximadamente 5.000 kJoules, sendo que para este cálculo usou-se o fator de rendimento energético apresentado por Kongjan et al. (2013), em que para cada $\mathrm{ml}$ de $\mathrm{H}_{2}$ convertido a partir da degradação da matéria orgânica obtém-se o rendimento de 12,9 Joules. (Vide Equação 26). O reator metanogênico obteve rendimento de metano por quilo de melaço aplicado de $387 \mathrm{LCH}_{4} \cdot \mathrm{Kgmelaço}^{-1}$, representando rendimento energético de 15.500 kJoules, para este cálculo usou-se o fator de rendimento energético apresentado por Kongjan et al. (2013), em que para cada ml de $\mathrm{CH}_{4}$ convertido a partir da degradação da matéria orgânica obtém-se o rendimento de 40,1 Joules. (Vide Equação 27).

A partir dos cálculos de rendimento energético do hidrogênio e metano calculados em kJoules de acordo com o proposto por Kongjan et al. (2013), pode-se calcular o ganho energético em kWh (QuiloWattshora) utilizando o fator de conversão, em que para cada

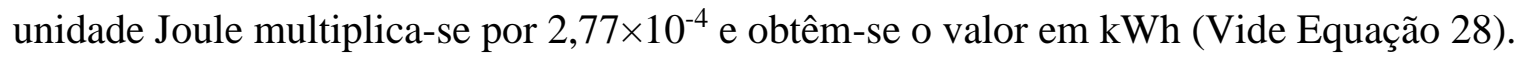

Os rendimentos e cálculos indicou que o reator acidogênico obteve ganho energético por quilo de melaço aplicado de aproximadamente de 1,4 kWh.Kgmelaço ${ }^{-1}$. Os rendimentos e cálculos indicou que o reator metanogênico obteve ganho energético de aproximadamente 4,3 KWh.Kgmelaço ${ }^{-1}$. Para finalidade de comparações e aplicabilidade, o ganho energético global do sistema de reatores de duas fases foi de aproximadamente 5,7 kWh.Kgmelaço-1 ${ }^{-1}$ (Tabela 27). 
Tabela 27: Ganho energético do sistema de reatores combinados

\begin{tabular}{|c|c|c|c|}
\hline \multicolumn{4}{|c|}{ Ganho Energético do Sistema de Reatores Combinados } \\
\hline \multirow{2}{*}{ Variáveis } & \multicolumn{3}{|c|}{ Ganho Energético Relativo } \\
\hline & L.Kgmelaço $^{-1}$ & Joules* & KWh.Kgmelaço $^{-1}$ \\
\hline $\begin{array}{l}\text { Reator Acidogênico } \\
\text { (Produção de } \mathrm{H}_{2} \text { ) }\end{array}$ & 392 & 5.000 & 1,4 \\
\hline $\begin{array}{l}\text { Reator Metanogênico } \\
\text { (Produção de } \mathrm{CH}_{4} \text { ) }\end{array}$ & 387 & 15.500 & 4,3 \\
\hline Ganho Energé & obal do Sistems & s Fases: 5 & h.K.Kgmelaço ${ }^{-1}$ \\
\hline
\end{tabular}

* Kongjan et al. (2013)

Com os dados obtidos acima pode-se alcançar várias comparações para a aplicabilidade do melaço em reatores anaeróbios, obtendo assim ganho energético e econômico sem comprometer a produção de açúcar e álcool das plantas produtivas das usinas sucroalcooleiras.

A partir do exposto a aplicação prática deste trabalho está relacionada com a produção dos biocombustíveis hidrogênio e metano, a remoção eficiente de matéria orgânica pela taxa de conversão de DQO, e utilização racional de matéria-prima, ou seja, a otimização dos bioprocessos envolvidos.

O processo anaeróbio contínuo de duas fases testado neste estudo demonstrou alta de produção de hidrogênio e metano a partir da biomassa proveniente das próprias plantas das usinas sucroalcooleiras (melaço da cana-de-açúcar).

A especificação da mistura de gases $\left(\mathrm{H}_{2}\right.$ e $\left.\mathrm{CH}_{4}\right)$ demonstrou pelo ganho energético obtido em kWh avaliados neste estudo, que a partir do sistema anaeróbio de duas fases se mostrou apropriado para nossa realidade, além disso, a eficiência de remoção de matéria orgânica no processo de dois estágios foi relativamente alta.

Por conseguinte, este processo anaeróbio de duas fases se mostrou eficiente e com potencial para ser utilizado para a recuperação de energia na forma de biocombustíveis, desde que demonstrados em estudos de viabilidade econômica. 
Produção de hidrogênio e metano a partir de subproduto da indústria sucroalcooleira, em reatores anaeróbios de fases separadas sob condição termofílica

142 


\section{CONCLUSÕES}

A partir dos resultados obtidos e da discussão apresentada para os experimentos realizados em sistema anaeróbio de duas fases (acidogênico seguido do metanogênico) para produção de hidrogênio e metano, alimentado com melaço da cana-de-açúcar em condição termofílica $\left(55^{\circ} \mathrm{C}\right)$, conclui-se que:

- Os resultados comparativos entre o desempenho dos reatores acidogênicos (R1 e $\mathrm{R} 2)$, operados sob as condições termofílicas $\left(55^{\circ} \mathrm{C}\right)$ e com as condições de aumento de carga impostas neste estudo (COV 30, 60 e 120 gDQO.Lreator ${ }^{-1} \cdot$ dia $^{-1}$ ), demonstrou que o reator inoculado com lodo de reator UASB e usando como material suporte a espuma de poliuretano, teve melhor desempenho na geração de metabólitos associados a via acidogênica, com aumento de aproximadamente 80\% na produção de hidrogênio, além de ser adequado na seleção de microbiota diversa envolvida direta e indiretamente na produção de hidrogênio, comparado ao reator inoculado com vinhaça auto fermentada e como material suporte o polietileno de baixa densidade.

- Nenhum pré-tratamento do inóculo foi necessário o que indicou que a condição termofílica imposta de $55^{\circ} \mathrm{C}$ e $\mathrm{TDH}$ de 2 horas melhorou os resultados de produtividade de contínua e estável de hidrogênio.

- As ferramentas de biologia molecular, especialmente o Sequenciamento massivo pela técnica metagenômica MiSeq ${ }^{\circledR}$ Illumina foi adequada no estudo de microrganismos presentes no inóculo e nos biorreatores revelando os diferentes filos e gêneros selecionados pelo aumento de COV aos reatores acidogênicos.

- Em ambos os reatores acidogênicos (R1 e R2) ocorreram a redundância funcional com a seleção de sequencias de microrganismos fermentadores do Filos Firmicutes, Proteobacteria e Bacterioidetes, envolvidos direta e indiretamente na produção de Hidrogênio. Em R2 a diversidade de Filos e gêneros fermentadores e produtores de 
hidrogênio foi superior a R1, com detecção também de Thermotogae, Actinobacteria, Chloroflexi, Synergistetes o que pode explicar a maior produção de hidrogênio neste biorreator com o aumento da COV aplicada.

- Os dados obtidos do desempenho do reator acidogênico, nas análises biomoleculares, juntamente com os resultados das análises de gases e ácidos voláteis orgânicos, demonstraram que a condição operacional de $55^{\circ} \mathrm{C}$ com $\mathrm{COV}$ de 120 gDQO.Lreator ${ }^{-1} \cdot \mathrm{dia}^{-1}$, e o TDH de 2 horas, foi adequada e favoreceu o metabolismo das bactérias fermentativas acidogênicas, produzindo continuamente e estável $\mathrm{H}_{2}$ por longo período de tempo (417 dias).

- A produção continua de $\mathrm{H}_{2}$ obtida nos resultados deste estudo está relacionada à associação das rotas metabólicas dos ácidos produtores de hidrogênio já consolidados pela literatura pertinente (acético e butírico) e pela produção de Hidrogênio pela rota do ácido lático.

- O sistema de duas fases se mostrou eficiente na remoção global de DQO com aproximadamente $90 \%$ de eficiência. O reator acidogênico foi responsável pela remoção de aproximadamente $10 \%$, enquanto o segundo reator teve aproximadamente $80 \%$ de contribuição de eficiência, indicando a robustez do sistema.

- A adaptação dos organismos metanogênicos às condições impostas de diminuição da solução álcali, como forma de diminuir custos operacionais, se apresentou eficiente comprovando adaptação dos organismos metanogênicos.

- O processo anaeróbio contínuo de duas fases em reator de leito estruturado demonstrou alta de produção de hidrogênio (392 LH 2. Kgmelaço $^{-1}$ ) e metano (387 $\mathrm{LCH}_{4} . \mathrm{Kgmelaço}^{-1}$ ) a partir da biomassa proveniente das próprias plantas das usinas sucroalcooleiras (melaço da cana-de-açúcar). O ganho energético do sistema após estabelecimento dos processos no sistema de reatores foi de 1,4 Kwh.Kgmelaço ${ }^{-1}$ 
para o reator acidogênico e 4,3 Kwh. $\mathrm{Kgmelaço}^{-1}$ para o reator metanogênico, com ganho global de 5,7 Kwh.Kgmelaço-1 ${ }^{-1}$, se mostrando apropriado para nossa realidade que busca a inserção de outras fontes energéticas à atual matriz.

- Dos pontos de vista científico e tecnológico este estudo deu mais um passo para a compreensão dos bioprocessos envolvidos nos sistemas anaeróbios em dois estágios produzindo hidrogênio e metano (biocombustíveis) continuamente e por longo período de tempo, usando o melaço de cana-de-açúcar como substrato. Este trabalho permite afirmar que o sistema proposto se apresenta como uma alternativa viável para a produção biológica de biocombustíveis a partir de matrizes orgânicas de elevada concentração. No entanto, desafios precisam ser superados para otimizar a produção continua de hidrogênio e metano nos sistemas de reatores em dois estágios. 
Produção de hidrogênio e metano a partir de subproduto da indústria sucroalcooleira, em reatores anaeróbios de fases separadas sob condição termofílica

146 


\section{TRABALHOS FUTUROS}

As lacunas observadas no decorrer do presente trabalho levaram às seguintes sugest

- Elevar TDH no reator acidogênico para 3 ou 4 horas, visando aumentar a taxa de conversão de carboidratos, intimamente relacionada com a produção de $\mathrm{H}_{2}$;

- Utilizar recirculação do efluente no reator acidogênico visando aumentar a conversão de carboidratos, intimamente relacionada com a produção de $\mathrm{H}_{2}$;

- Avaliar a estabilidade e o rendimento no reator de segunda fase (metanogênico) na condição de aumento de conversão de carboidratos, comparando com a obtida neste estudo;

- Realizar análise econômica do sistema de reatores em duas fases para geração de energia a partir do biogás produzido na digestão anaeróbia da vinhaça, a fim de verificar a viabilidade econômica, comparada aos outros usos do melaço;

- Realizar aumento de escala no sistema de duas fases proposto, visando o balanço de massa e de energia do sistema. 
Produção de hidrogênio e metano a partir de subproduto da indústria sucroalcooleira, em reatores anaeróbios de fases separadas sob condição termofílica

148 


\section{REFERÊNCIAS}

AGÊNCIA NACIONAL DE ENERGIA ELÉTRICA - ANEEL (2009). Atlas da energia elétrica do Brasil - Fatores de conversão. $3^{\mathrm{a}}$ edição, 236p.

ALBANEZ, R. (2015). Codigestão de vinhaça e melaço em biorreator anaeróbio operado em bateladas sequenciais com biomassa imobilizada visando a produção de hidrogênio. Tese (Doutorado) - Escola de Engenharia de São Carlos, Universidade de São Paulo, 314p.

ALBERTSEN, M.; HANSEN, L.B.S.; SAUNDERS, A.M.; NIELSEN, P.H.; NIELSEN, K.L. (2012). A metagenome of a full-scale microbial community carrying out enhanced biological phosphorus removal. International Society Microbial Ecology Journal (ISME), v. 6, 1094-1106p.

ANAIS V SEMINÁRIO DO PROJETO TEMÁTICO (2015). Produção de Bioenergia no Tratamento de Águas Residuárias e Adequação Ambiental dos Efluentes e Resíduos Gerados. Programa de Pós-Graduação em Engenharia Hidráulica e Saneamento (EESC/USP), Departamento de Engenharia Química (CCET/UFSCAR), Departamento de Engenharia Química e de Alimentos (EEM/IMT), Departamento de Físico-Química (IQSC/USP), São Carlos/SP. Agência de Fomento FAPESP, 526p.

ANJOLA-ROJAS, M.P. (2014). Estratégias para a Produção Contínua de Hidrogênio em Reator Anaeróbio de Leito Fixo. Tese (Doutorado) - Escola de Engenharia de São Carlos, Universidade de São Paulo, 161P.

ANTONOPOULOU, G.; GAVALA, H.; SKIADAS, I.; ANGELOPOULOS, K.; LYBERATOS, G. (2008). Biofuels generation from sweet sorghum: fermentative hydrogen production and anaerobic digestion of the remaining biomass. Bioresource Technology, n.99 (1), 110-119p.

ANTONOPOULOU, G.; GAVALA, H.N.; SKIADAS, I.V.; LYBERATOS, G. (2010). Influence of pH on fermentative hydrogen production from sweet sorghum extract. International Journal of Hydrogen Energy, n.35, 1921-1928p.

ANZOLA-ROJAS, M.P.; FONSECA, S.G.; SILVA, C.C.; OLIVEIRA, V.M.; ZAIAT, M. (2015). The use of the carbon/nitrogen ration and specific organic loading rate as tools for improving biohydrogen production in fixed-bed reactors. Biotechnology Reports, n.5, 46$54 \mathrm{p}$. 
APHA, AWWA, WEF. (2012). Standard methods for examination of water and wastewater. American Public Health Association, American Water Works Association, Water Environment Federation, Washington, D.C., $22^{\text {nd }}$ ed.

BRAGA, A.F.M.; FERRAZ., A.D.N.; ZAIAT, M. (2015). Thermophilic biohydrogen production using a UASB reactor: performance during long-term operation. Journal of Chemical Technology and Biotechnology, vol. 91, Issue 4, 967-976p.

BUSTIN, S.A. (2002). Quantification of mRNA using real-time reverse transcription PCR (qPCR): trends and problems. Journal of Molecular Endocrinology, Bristol, v. 29, 29-39p.

BUSTIN, S.A.; BENES, V.; GARSON, J.A.; HELLEMANS, J.; HUGETT, J.; KUBISTA, M.; MUELLER, R.; NOLN, T.; PFAFFL, M.W.; SHIPLEY, G.L.; VANDESOMPELE, J.; WITTWER, C.T. (2009). The MIQE guidelines: minimum information for publication of quantitative real-time PCR experiments. Clinical Chemistry, n55(4), 611-622p.

CAVINATO, C.; GIULIANO, A.; BOLZONELLA, D.; PAVAN, P.; CECCHI, F. (2012). Biohythane production from food waste by dark fermentation coupled with anaerobic digestion process: a long-term pilot scale experience. International Journal of Hydrogen Energy, 37, 11549-11555p.

CHEN, C.C.; LIN, C.Y. (2003). Using sucrose as a substrate in an anaerobic hydrogenproducing reactor. Advances in Environmental Research 7, 695-699p.

CHEN, C.C.; LIN, C.Y.; CHANG, J.S. (2001). Kinetics of hydrogen production with continuous anaerobic cultures utilizing sucrose as the limiting substrate. Applied Microbiology Biotechnology, v. 57, 56-64p.

CHENG, H.; WNAG, L.; CHUNG, M.; CHAN, K. (2016). Biological hydrogen and methane production from bagasse bioethanol fermentation residues using a two-stage bioprocess. Bioresource Technology, doi: http://dx.doi.org/10.1016/j.biortech.2015.12.084. In Press.

CHU, C.F.; LI, Y.Y.; XU, K.Q.; EBIE, Y.; INAMORI, Y.; KONG, H.N. (2008). A pH- and temperature-phased two-stage process for hydrogen and methane production from food waste. International Journal of Hydrogen Energy, vol. 33, 4739-4746p.

DAGNELIE, P. (1973). Estatística - Teoria e Métodos II. Publicações Europa-América Ltda. 
DEMIREL B.; YENIGUIN, O. (2002). Two-phase anaerobic digestion processes: a review. Journal of Chemical Technology and Biotechnology, Volume 77, Issue 7July, 743-755p.

DEUBLEIN D.; STEINHAUSER A. (2010). Biogas from Waste and Renewable Resources: An Introduction, 2nd, Revised and Expanded Edition. WILEY-VCH Verlag GmbH \& Co. KGaA, Weinheim, 578p.

DILALLO, R.; ALBERTSON, O.E. (1961). Volatile acids by direct titration. Journal Water Pollution Control Federation, 33, 356-365.

DUBOIS, S.M.; GILLES, K.A.; HAMILTON, J.L.; REBERS, P.A.; SMITH, F. (1956). Colorimetric methods for determination of sugars and related substance. Analytical Chemistry, (228): 13-21p.

FANG, H.H.P; ZHANG, T.; LI, C. (2006) Characterization of Fe-hydrogenase genes diversity and hydrogen-producing population in an acidophilic sludge. Journal of Biotechnology, n.126, 357-364p.

FANG, Y.T.; LIU, H. (2002). Effect of pH on hydrogen production from glucose by a mixed culture. Bioresource Technology, n. 82:87-93p.

FERNANDES, B.S. (2008). Produção de hidrogênio em reator anaeróbio de leito fixo. Tese (Doutorado) - Escola de Engenharia de São Carlos, Universidade de São Paulo, 115p.

FERRAZ., A.D.N (2013). Digestão anaeróbia da vinhaça da cana de açúcar em reator acidogênico de leito fixo seguido de reator metanogênico de manta de lodo. Tese (Doutorado) - Escola de Engenharia de São Carlos, Universidade de São Paulo, 164p.

FERRAZ., A.D.N.; ETCHEBEHERE, C.; ZAIAT, M. (2015). High organic loading rate on thermophilic hydrogen production and metagenomic study at an anaerobic packed-bed reactor treating a residual liquid stream of a Brazilian biorefinery. Bioresource Technology 186, 81-88p.

FERRAZ., A.D.N.; ETCHEBEHERE, C.; ZAIAT, M. (2015b). Mesophilic hydrogen production in acidogenic packed-bed reactors (APBR) using raw sugarcane vinasse as substrate: Influence of support materials. Anaerobe (London. Print), v. 34, 94-105p.

FERRAZ., A.D.N.; KOYAMA, M.H.; ARAÚJO, M.M.; ZAIAT, M. (2016). Thermophilic anaerobic digestion of raw sugarcane vinasse. Renewable Energy 89, 245-252p. 
152

FERRAZ., A.D.N.; WENZEL, J.; ETCHEBEHERE, C.; ZAIAT, M. (2014). Effect of organic loading rate on hydrogen production from sugarcane vinasse in thermophilic acidogenic packed bed reactors. International Journal of Hydrogen Energy, 39: 16852-16862p.

FONTES LIMA, D.M.; ZAIAT, M. (2012). The influence of the degree of back-mixing on hydrogen production in an anaerobic fixed-bed reactor. International journal of hydrogen energy, v. 37, p. 9630-9635p.

GODOI, L.; DAMIANOVIC, M.H.R.Z.; FORESTI, E. (2015). Sulfidogenesis interference on methane production from carbohydrate-rich wastewater. IWA Publishing, Water Science and Technology, v.74, 1644-1652p.

GOODALL, D.W. (1966). A new similarity index based on probability. Biometrics, 22(4): 882-907p.

GRIFFITHS, R.I.; WHITELEY, A.S.; O'DONNELL, A.G.; BAILEY, M.J. (2000). Rapid Method for Coextraction of DNA and RNA from Natural Environments for Analysis of Ribosomal DNA- and rRNA-Based Microbial Community Composition. Applied Environmental Microbiology, vol. 66 n.12, 5488-5491p.

GUO, J.; PENG, Y.; NI, B.J.; HAN, X.; FAN, L.; YUAN, Z. (2015). Dissecting microbial community structure and methane-producing pathways of a full-scale anaerobic reactor digesting activated sludge from wastewater treatment by metagenomic sequencing. Microbial Cell Factories, v. 14, 33p.

HAFEZ H.; NAKHLA, G.; NAGGAR, H.E.; ELBESHBISHY, E.; BAGHCHEHSARAEE, B. (2010). Effect of organic loading on a novel hydrogen bioreactor. International Journal of Hydrogen Energy, 35, 81-92p.

HAN, W.; YE, M.; ZHU, A.J.; HUANG, J.G.; ZHAO, H.T.; LI, Y.F. (2015). A combined bioprocess based on solid-state fermentation for dark fermentative hydrogen production from food waste. Journal of Cleaner Production, 1-6p.

HIRASAWA, J. S. (2007). Avaliação da metanogênese e sulfetogênese na presença de oxigênio, sob diferentes relações etanol/sulfato, utilizando técnicas de Biologia Molecular. Tese (Doutorado) - Escola de Engenharia de São Carlos, Universidade de São Paulo. 134p.

KAPDAN, I.K.; KARGI, F. (2006). Bio-hydrogen production from waste materials. Enzyme and Microbial Technology, v.38, 569-582p. 
KONGJAN, P.; O-THONG, S.; KOTAY, M.; MIN, B.; ANGELIDAKI, I (2010). Biohydrogen production from wheat straw hydrolysate by dark fermentation using extreme thermophilic mixed culture. Biotechnology Bioenergy. N.105, 899-908p.

KONGJAN, P.; O-THONG, S.; ANGELIDAKI, I. (2011). Performance and microbial community analysis of two-stage process with extreme thermophilic hydrogen and thermophilic methane production from hydrolysate in UASB reactors. Bioresource Technology, n. 102, 4028-4035p.

KONGJAN, P.; O-THONG, S.; ANGELIDAKI, I. (2013). Hydrogen and methane production from desugared molasses using a two-stage thermophilic anaerobic process. Engineering in Life Sciences, 13, No. 2, 118-125p.

KRAMER, J.T.; BAGLEY, D.M. (2007). Improving the yield from fermentative hydrogen production. Biotechnology Letters. V. 29, 685p.

KUDO, Y.; NAKAJIMA, T.; TARO, M.; OYAIZU, H. (2006) Methanogen flora of paddy soils in Japan. Federation of European Microbiological Society, Microbiology Ecology, n. 22 vol 1, 39-48p.

LAZARO, C.Z. (2009). Obtenção e caracterização filogenética de consórcio de bactérias fototróficas púrpuras não sulfurosas consumidoras de ácidos orgânicos visando a produção de hidrogênio em reator anaeróbio de batelada. Dissertação (Mestrado) Departamento de Engenharia Hidráulica e Saneamento, Escola de Engenharia de São Carlos da Universidade de São Paulo - EESC/USP, São Carlos, SP, 127p.

LEE, D.; EBIE, Y.; XU, K.; LI, Y.; INAMORI, Y. (2010). Continuous $\mathbf{H}_{2}$ and $\mathbf{C H}_{4}$ production from high-solid food waste in the two-stage thermophilic fermentation process with the recirculation of digester sludge. Bioresource Technology 101 (1S), 42-47p.

LEITE, J.A.C.; FERNANDES B.S.; POZZI, E.; BARBOZA, M.; ZAIAT, M. (2008). Application of an anaerobic packed-bed reactor for the production of hydrogen and organic acids. International Journal of Hydrogen Energy, 33:579-586p.

LEVIN, D.B.; PITT, L.; LOVE, M. (2004). Biohydrogen production: prospects and limitations to practical application. International Journal of Hydrogen Energy, v. 29, p. 173$185 \mathrm{p}$.

LI, A.; CHU, Y.; WANG, X.; REN, L.; YU, J.; LIU, X. (2013). A pyrosequencing-based metagenomic study of methane-producing microbial community in solid-state biogas reactor. Biotechnology Biofuels, v. 6, 3p. 
154

LIMA, U. A. (1987). Tecnologia das fermentações, v. 1. São Paulo: Edgar Blucher, 285p.

LIU, AC.; CHOU, C.Y.; CHEN, L.L.; KUO, C.H.; (2015). Bacterial community dynamics in a swine wastewater anaerobic reactor revealed by $16 \mathrm{~S}$ rDNA sequence analysis. Journal Biotechnology, v. 194, 124-131p.

MARDIS, E.R. (2008). The impact of next-generation sequencing technology on genetics. Trends Genetic., v. 24, 133-141p.

MASSET, J.; CALUSINSKA, M.; HAMILTON, C.; HILIGSMANN, S.; JORIS, B.; WILMOTTE, A.; THONART, P. (2012). Fermentative hydrogen production from glucose and starch using pure strains and artificial co-cultures of Clostridium spp. Biotechnology for Biofuels, 2012, 25-35p.

MATSUMOTO, M.; NISHIMURA, Y. (2007). Hydrogen Production by Fermentation Using Acetic Acid and Lactic Acid. Journal of Bioscience and Bioengineering. Vol. 103, No. 3, 236-241p.

McCARTY, P. L.; McKINNEY, R.E. (1961). Volatile acids toxicity in anaerobic digestion. Water Pollution Control Federation, 33(3), 223-232p.

MORAES, B.; ZAIAT, M.; BONOMI, A. (2015). Anaerobic digestion of vinasse from sugar cane ethanol production in Brazil: Challenges and perspectives. Renewable and Sustainable Energy Reviews n. 44, 888-903p.

MORETTIN, P.A.; BUSSAB, W.O. (2011). Estatística básica. Editora Saraiva, $7^{\text {a }}$ edição, São Paulo - SP, 540p.

MUYZER, G.; DEWAAL, E.C.; UITTERLINDEN, A.G. (1993). Profiling of complex microbial-populations by denaturing gradient gel-electrophoresis analysis of polymerase chain reaction-amplified genes-coding for16S ribosomal-RNA. Applied Environmental Microbiology, n.59, 695-700p.

MUYZER, G.; SMALLA, K. (1998) Application of denaturing gradient gel electrophoresis (DGGE) and temperature gradient gel electrophoresis (TGGE) in microbial ecology. Antonie Van Leeuwenhoek., January, n.73, vol (1), 127-41p.

NARS, N.; ELBESHBISHY, E.; HAFEZ, H.; NAKHLA, G.; NAGGAR, M.H. (2012). Comparative assessment of single-stage and two-stage anaerobic digestion for the treatment of thin stillage. Bioresource Technology v.111, 122-126p. 
NUBEL, U.; ENGELEN, B.; FELSKE, A.; SNAIDR, J.; WIESHUBER, A.; HOLDER, E.L.; MILLER, K.M.; HAINES, J.R.; (1999). Sequence heterogeneities of genes encoding $16 S$ rRNAs in Paenibacillus polymyxa detected by temperature-gradient gel electrophoresis. Journal Bacteriology, n. 178, 5636-5643p.

OHNISHI, A.; HASEGAWA, Y.; ABE, S.; BANDO, Y.; FUJIMOTO, N.; SUZUKI, M. (2012). Hydrogen fermentation using lactate as the sole carbon source: Solution for 'blind spots' in biofuel production. The Royal Society of Chemistry, 2, 8332-8340p.

OLIVEIRA, M. R. (2005). Avaliação estatística da produção de levana por Zymomonas mobilis ATCC 31821 utilizando fontes de carboidratos regionais e de baixo custo. Dissertação (Mestrado em Biotecnologia) - Departamento de Bioquímica e Biotecnologia, Universidade Estadual de Londrina, Londrina, 88p.

PEIXOTO, G. (2011). Sistema fermentativo de duas fases para a produção de hidrogênio e metano a partir de esgoto sanitário combinado com águas residuárias industriais. Tese (Doutorado) - Escola de Engenharia de São Carlos, Universidade de São Paulo, 214p.

PEIXOTO, G.; SAAVEDRA, N.K.; VARESCHE, M.B.A.; ZAIAT, M. (2011). Hydrogen production from soft-drink wastewater in an upflow anaerobic packed-bed reactor. International Journal of Hydrogen Energy, v.36, 8953-8966p.

PENTEADO, E.D.; LAZARO, C.Z.; SAKAMOTO, I.K.; ZAIAT, M. (2013). Influence of seed sludge and pretreatment method on hydrogen production in packed-bed anaerobic reactors. International Journal of Hydrogen Energy, 38(14): 6137-6145p.

PIACENTE, F. J. (2005). Agroindústria canavieira e o sistema de gestão ambiental: o caso das usinas localizadas nas bacias hidrográficas dos rios Piracicaba, Capivari e Jundiaí. Dissertação (Mestrado em Desenvolvimento Econômico) - Universidade Estadual de Campinas, Campinas, 181p.

POHLAND F.G.; GHOSH S. (1971). Developments in anaerobic stabilization of organic wastes--the two-phase concept. Environmental Letters, 1(4):255-266p.

QIN, J.; LI, R.; RAES, J.; ARUMUGAM, M.; BURGDORF, K.S.; MANICHANH, C. (2010). A human gut microbial gene catalogue established by metagenomic sequencing. Nature, $\mathrm{v}$. 464, 59-70p.

REIS, C.M.; CAROSIA, M.F.; SAKAMOTO, I.K.; VARESCHE, M.B.A.; SILVA, E.L. (2015). Evaluation of hydrogen and methane production from sugarcane vinasse in an anaerobic fluidized bed reactor. International Journal of hydrogen energy, n. 40, 8498-8509p. 
156

ROALKVAM, I.; DRØNEN, K.; STOKKE, R.; DAAE, F.L.; DAHLE, H.; STEEN, I.H. (2015) Physiological and genomic characterization of Arcobacter anaerophilusIR-1 reveals new metabolic features. Epsilonproteobacteria Front Microbiololgy, v6: 987p.

RODRÍGUEZ, E.; LOPES, A.; POLANCO, M.; STAMS, A.J.M.; GARCÍA-ENCINA, P.A. (2012). Molecular analysis of the biomass of a fluidized bed reactor treating synthetic vinasse at anaerobic and micro-aerobic conditions. Applied Microbiology Biotechnology n.93, 2181-2191p.

ROESCH, L.F.W.; FULTHORPE, R.R.; RIVA, A.; CASELLA, G.; HADWIN, A.K.M.; KENT, A.D.; DAROUB, S.H.; CAMARGO, F.A.O.; FARMERIE, W.G.; TRIPLETT, E.W. (2007). Pyrosequencing enumerates and contrasts soil microbial diversity. International Society Microbial Ecology Journal (ISME), v. 1, 283-290p.

SAIA, F.T.; SOUZA, T.S.O.; DUARTE, R.T.D.; POZZI, E.; FONSECA, D.; FORESTI, E. (2015). Microbial community in a pilot-scale bioreactor promoting anaerobic digestion and sulfur-driven denitrification for domestic sewage treatment. Bioprocess and Biosystems Engineering (Print), v. 38, 1-12p.

RIPLEY, L.E.; BOYLE, W.C.; CONVERSE, J.C. (1986). Improved alkalimetric monitoring for anaerobic digestion of high strength wastes. Journal Water Pollution Control Federation. 58, 406-411p.

ROMBLA, M.O; PRADA, A.R; COOPAT, T.S; CARRACEDO, G.B. (1999). Manual dos derivados da cana-de-açúcar. Brasília: ABIPTI, 474p.

SHIPLEY, G.L. (2006). An introduction to real-time PCR. In: DORAK, M.T. (Ed.). Realtime PCR. New York: Taylor \& Francis Group, 1-31p.

SHOW, K.Y.; LEE, D.J.; TAY, J.H.; LIN, C.Y.; CHANG, J.S. (2012). Biohydrogen production: Current perspectives and the way forward. International Journal of Hydrogen Energy, v.37,.15616-15631p.

SIKORA, A.; BŁASZCZYK, M.; JURKOWSKI, M.; ZIELENKIEWICZ, U. (2013). Lactic Acid Bacteria in Hydrogen-Producing Consortia: On Purpose or by Coincidence? In: Biochemistry, Genetics and Molecular Biology "Lactic Acid Bacteria $-R$ \& D for Food, Health and Livestock Purposes", Marcelino Kongo, editor, ISBN 978-953-51-0955-6, Cap. 21.

SILVA, A.J.; HIRASAWA, J.S.; VARESCHE, M.B.A.; FORESTI, E.; ZAIAT, M. (2006). Evaluation of support materials for the immobilization of sulfate-reducing bacteria and methanogenic archaea. Ecology Environmental Microbiology, Anaerobe, n.12, 93-98p. 
SILVA, A.J.; DOMINGUES, M.R.; HIRASAWA, J.S.; VARESCHE, M.B.A.; FORESTI, E.; ZAIAT, M. (2011). Kinetic modeling and microbial assessment by Fluorescent in Situ Hybridization in anaerobic sequencing batch biofilm reactors treating sulfate-rich wastewater. Brazilian Journal of Chemical Engineering, vol. 28, n. 2, 209-219p.

SOGIN, M.L.; MORRISON, H.G.; HUBER, J.A.; WELCH, D.M.; HUSE, S.M.; NEAL, P.R.; ARRIETA, F.M.; HERNDL, G.J. (2006). Microbial diversity in the deep sea and the underexplored rare biosphere. Proceedings of the National Academy of Sciences, USA, v. 103, 12115-12120p.

SPEECE, R.E (1996). Anaerobic Biotechnology for Industrial Wastewaters. Archae Press, $394 p$.

SUNDBERG, C.; AL-SOUD, W.A.; LARSSON, M.; ALM, E.; YEKTA, S.S.; SVENSSON B.H. (2013). 454 pyrosequencing analyses of bacterial and archaeal richness in 21 fullscale biogas digesters. Federation of European Microbiological Society, Microbiology Ecology, v.85, 612-626p.

TAN, H.Q.; LI, T.T.; ZHU, C.; ZHANG, X.Q.; WU, M.; ZHU, X.F. (2012) Parabacteroides chartae sp. nov., an obligately anaerobic species from wastewater of a paper mil. International Journal of Systematic and Evolutionary Microbiology, v.62, 2613-2617p.

TEMUDO, M. F.; MUYZER, G.; KLEEREBEZEM, R.; van LOOSDRECHT, M. C. M. (2008). Diversity of microbial communities in open mixed culture fermentations: impact of the $\mathbf{p H}$ and carbon source. Environmental Biotechnology Applied Microbiology Biotechnology, 80:1121-1130p.

TERRY BROWN, A.I (2012). Comportamento da Biomassa de Reator Anaeróbio Utilizado no Processamento de Vinhaça de Destilaria de Álcool. Tese (Doutorado) - Escola de Engenharia de São Carlos, Universidade de São Paulo, 114p.

UENO, Y.; FUKUI, H.; GOTO, M. (2007). Operation of a Two-Stage Fermentation Process Producing Hydrogen and Methane from Organic Waste. Environmental Science Technology, v. 41, pag. 1413-1419p.

ÚNICA (2016). União das Indústrias de Cana-de-Açúcar. http://www.unica.com.br/, portal web, último acesso em 03 de outubro de 2016.

PERNA, V.; CASTELlÓ, E.; WENZEL, J.; ZAMPOL, C.; FONTES LIMA, D.M.; BORZACCONI, L.; VARESCHE, M.B.A.; ZAIAT, M; ETCHEBEHERE, E. (2013). Hydrogen production in an upflow anaerobic packed bed reactor used to treat cheese whey. International Journal of Hydrogen Energy, 38(1):54-62p. 
158

VAN LIER, J.B. (1996). Limitations of thermophilic anaerobic wastewater treatment and the consequences for process design. Antonie van Leeuwenhoek January, v.69, Issue 1, 1$14 \mathrm{p}$.

YANG, Y.; YU, K.; XIA, Y.; LAU, F.T.K.; TANG, D.T.W.; FUNG, W.C.; FANG, H.H.P.; ZHAN, G.T. (2014). Metagenomic analysis of sludge from full-scale anaerobic digesters operated in municipal wastewater treatment plants. Applied Microbiology and Biotechnology, v. 98, 5709-5718p.

WALISZEWSKI, K. N.; ROMERO, A.; PARDIO, V. T. (1997). Use of cane condensed molasses in feeding broilers. Animal Feed Science Technology, Amsterdam, v.67, 253-258p. WANG, B.; LI, Y.; REN, N. (2013). Biohydrogen from molasses with ethanol-type fermentation: Effect of hydraulic retention time. International Journal of Hydrogen Energy, n.38, p.4361 - 4367p.

WONG, M.T.; ZHANG, D.; LI, J.; HUI, R.K.H.; TUN, H.M.; BRAR, M.S. (2013). Towards a metagenomic understanding on enhanced biomethane production from waste activated sludge after pH 10 pretreatment. Biotechnology Biofuels., v. 6, 38p. 


\section{ANEXO}

\section{Obtenção das Curvas para Gases - Cromatógrafo Shimadzu GC-2010}

1) Resultados das curvas com todos os pontos (10 a $1000 \mu \mathrm{L}$, correspondentes, em micromols, de 0,10107 a 10,10729), em que - $y$-é a área cromatográfica e $-x$ - o número de micromols do gás correspondente.

2) Resultados das curvas baixas, de 10 a $300 \mu \mathrm{L}(0,10107$ a 3,03219 micromols).

3) Resultados das curvas altas, de 100 a $1000 \mu \mathrm{L}(1,01073$ a 10,10729 micromols).

Tabela A1: Valores Obtidos em todos os pontos:

\begin{tabular}{cccccc}
\hline $\begin{array}{c}\text { Volume } \\
(\mathbf{e m} \boldsymbol{\mu L})\end{array}$ & $\begin{array}{c}\text { Número de } \\
\text { micromols }\end{array}$ & $\begin{array}{c}\text { Área } \\
\text { cromatográfica } \\
\mathbf{H}_{\mathbf{2}}\end{array}$ & $\begin{array}{c}\text { Área } \\
\text { cromatográfica } \\
\mathbf{N}_{\mathbf{2}}\end{array}$ & $\begin{array}{c}\text { Área } \\
\text { cromatográfica }_{\mathbf{C H}_{\mathbf{4}}}\end{array}$ & $\begin{array}{c}\text { Área } \\
\text { cromatográfica } \\
\mathbf{C O}_{\mathbf{2}}\end{array}$ \\
\hline 10 & 0,10107 & 58341,40 & 7104,03 & 15529,53 & 4848,08 \\
20 & 0,20215 & 128079,70 & 16202,95 & 40641,90 & 13169,00 \\
30 & 0,30322 & 231015,13 & 21102,38 & 72632,10 & 23032,55 \\
60 & 0,60644 & 465630,18 & 44233,38 & 150985,70 & 48748,83 \\
80 & 0,80858 & 600544,70 & 61663,15 & 199767,45 & 64508,28 \\
100 & 1,01073 & 760789,85 & 69369,25 & 240706,33 & 77998,23 \\
200 & 2,02146 & 1292565,50 & 112913,90 & 400221,05 & 127733,75 \\
300 & 3,03219 & 1653617,75 & 150055,25 & 529048,98 & 168699,68 \\
400 & 4,04292 & 1597315,58 & 151155,60 & 533185,22 & 171185,97 \\
500 & 5,05364 & 2243740,35 & 209526,73 & 748380,18 & 241377,00 \\
600 & 6,06437 & 2730294,88 & 262927,30 & 935947,18 & 300533,63 \\
800 & 8,08583 & 3320089,68 & 327237,83 & 1154884,25 & 367842,15 \\
1000 & 10,10729 & 3869556,38 & 363574,53 & 1279868,40 & 405685,73 \\
\hline
\end{tabular}

Tabela A2: Limites de detecção e de quantificação:

\begin{tabular}{lcc}
\hline \multicolumn{1}{c}{ Gás } & LD $(\boldsymbol{\mu m o l s})$ & LQ $(\boldsymbol{\mu m o l s})$ \\
\hline Hidrogênio & 0,717 & 2,173 \\
Nitrogênio & 0,663 & 2,010 \\
Metano & 0,743 & 2,250 \\
Gás Carbônico & 5,733 & 17,373 \\
\hline
\end{tabular}


160

Tabela A3: Curva de todos os pontos:

\begin{tabular}{lccc}
\hline \multicolumn{1}{c}{ Gás } & $\begin{array}{c}\text { Tempo de } \\
\text { retenção }(\text { min) }\end{array}$ & Reta de calibração & \multirow{2}{*}{$\mathbf{R}^{\mathbf{2}}$} \\
\hline Hidrogênio & 2,01 & $\mathrm{y}=379450,996 \mathrm{x}+248244,4005$ & 0,9778 \\
Nitrogênio & 2,32 & $\mathrm{y}=36252,44674 \mathrm{x}+22674,55378$ & 0,9808 \\
Metano & 3,22 & $\mathrm{y}=129206,3061 \mathrm{x}+72884,95267$ & 0,9791 \\
Gás Carbônico & 4,61 & $\mathrm{y}=41099,9595 \mathrm{x}+24014,26514$ & 0,9776 \\
\hline
\end{tabular}

Tabela A4: Curva baixa (10 a $300 \mathrm{uL}$ ):

\begin{tabular}{lccc}
\hline \multicolumn{1}{c}{ Gás } & $\begin{array}{c}\text { Tempo de } \\
\text { retenção }(\text { min) }\end{array}$ & Reta de calibração & \multirow{2}{*}{$\mathbf{R}^{2}$} \\
\hline Hidrogênio & 2,01 & $\mathrm{y}=551056,7899 \mathrm{x}+91854,06387$ & 0,9733 \\
Nitrogênio & 2,32 & $\mathrm{y}=48342,79352 \mathrm{x}+11469,08129$ & 0,9712 \\
Metano & 3,22 & $\mathrm{y}=174685,8699 \mathrm{x}+29631,59066$ & 0,9735 \\
Gás Carbônico & 4,61 & $\mathrm{y}=55664,78193 \mathrm{x}+9830,29933$ & 0,9709 \\
\hline
\end{tabular}

Tabela A5: Curva alta (100 a $1000 \mathrm{uL})$ :

\begin{tabular}{lccc}
\hline \multicolumn{1}{c}{ Gás } & $\begin{array}{c}\text { Tempo de } \\
\text { retenção }(\mathbf{m i n})\end{array}$ & Reta de calibração & \multirow{2}{*}{$\mathbf{R}^{\mathbf{2}}$} \\
\hline Hidrogênio & 2,01 & $\mathrm{y}=341559,9085 \mathrm{x}+500527,1375$ & 0,9781 \\
Nitrogênio & 2,32 & $\mathrm{y}=33564,72579 \mathrm{x}+40461,47846$ & 0,9757 \\
Metano & 3,22 & $\mathrm{y}=118542,4492 \mathrm{x}+143685,6491$ & 0,9736 \\
Gás Carbônico & 4,61 & $\mathrm{y}=37537,02265 \mathrm{x}+47675,73719$ & 0,9718 \\
\hline
\end{tabular}

Método: Metano Rampa 17 marco 10 (Configurado pelo usuário).

Cromatógrafo gasoso Shimadzu GC-2010 com detector de condutividade térmica (DCT).

Coluna: Carboxen 1010 PLOT, 30m x 0,53mm.

Temperatura do injetor: $220^{\circ} \mathrm{C}$, gás de arraste: argônio.

Split: 2,0; fluxo na coluna: 5,66 mL. $\mathrm{min}^{-1}$.

Temperatura do detector: $230^{\circ} \mathrm{C}$.

Corrente: $35 \mathrm{~mA}$, polaridade negativa.

Make-up: Argônio 12 mL.min ${ }^{-1}$.

Temperatura do forno: $130-135^{\circ} \mathrm{C}(5,5 \mathrm{~min}), 46^{\circ} \mathrm{C} \cdot \mathrm{min}^{-1}$. 


\section{APÊNDICE A}

\section{Expressões para Cálculo dos Gases}

Tabela A 1: Expressão para cálculo dos gases de todos os pontos

\begin{tabular}{|c|c|c|c|c|c|}
\hline \multirow{2}{*}{ Gás } & \multirow{2}{*}{$\begin{array}{c}\text { Tempo de } \\
\text { retenção } \\
(\text { min }) \\
\end{array}$} & \multirow{2}{*}{$\begin{array}{c}\text { *Reta de calibração } \\
\mathbf{y}=\mathbf{A x}+\mathbf{B}\end{array}$} & \multirow{2}{*}{$\mathbf{R}^{2}$} & \multicolumn{2}{|c|}{$* * x=1 . A y^{-1}-B \cdot A^{-1}$} \\
\hline & & & & 1. $A^{-1}$ & B. $A^{-1}$ \\
\hline Hidrogênio & 2.01 & $\begin{array}{c}\mathrm{y}=379450,996 \mathrm{x}+ \\
248244,4005\end{array}$ & 0.9778 & 2.63539E-06 & 0.654219921 \\
\hline Nitrogênio & 2.32 & $\begin{array}{c}y=36252,44674 x+ \\
22674,55378\end{array}$ & 0.9808 & $2.75843 \mathrm{E}-05$ & 0.625462715 \\
\hline Metano & 3.22 & $y=129206,3061 x+$ & 0.9791 & 7.73956E-06 & 0.564097488 \\
\hline $\begin{array}{l}\text { Gás } \\
\text { Carbônico }\end{array}$ & 4.61 & $\begin{array}{c}\mathrm{y}=1099,9595 \mathrm{x}+ \\
24014,26514\end{array}$ & 0.9776 & 2.43309E-05 & 0.584289265 \\
\hline
\end{tabular}

Tabela A 2: Expressão para cálculo dos gases de curva baixa

\begin{tabular}{|c|c|c|c|c|c|}
\hline \multirow{2}{*}{ Gás } & \multirow{2}{*}{$\begin{array}{l}\text { Tempo de } \\
\text { retenção } \\
(\text { min) }\end{array}$} & \multirow{2}{*}{$\begin{array}{c}\text { *Reta de calibração } \\
\mathbf{y}=\mathbf{A x}+\mathbf{B}\end{array}$} & \multirow{2}{*}{$\mathbf{R}^{2}$} & \multicolumn{2}{|c|}{$* * x=1 . A y^{-1}-B \cdot A^{-1}$} \\
\hline & & & & 1.A $A^{-1}$ & $1 . A^{-1}$ \\
\hline Hidrogênio & 2.01 & $\begin{array}{c}\mathrm{y}=551056,7899 \mathrm{x}+ \\
91854,06387\end{array}$ & 0.9733 & 1.81469E-06 & 0.16668711 \\
\hline Nitrogênio & 2.32 & $\begin{aligned} y= & 48342,79352 x+ \\
& 11469,08129\end{aligned}$ & 0.9712 & $2.06856 \mathrm{E}-05$ & 0.237244902 \\
\hline Metano & 3.22 & $\begin{aligned} y= & 174685,8699 x+ \\
& 29631,59066\end{aligned}$ & 0.9735 & 5.72456E-06 & 0.169627862 \\
\hline $\begin{array}{l}\text { Gás } \\
\text { Carbônico }\end{array}$ & 4.61 & $\begin{array}{c}\mathrm{y}= \\
\mathrm{5} 5664,78193 \mathrm{x}+ \\
9830,29933\end{array}$ & 0.9709 & $1.79647 \mathrm{E}-05$ & 0.176598183 \\
\hline
\end{tabular}

Tabela A 3: Expressão para cálculo dos gases de curva alta

\begin{tabular}{|c|c|c|c|c|c|}
\hline \multirow{2}{*}{ Gás } & \multirow{2}{*}{$\begin{array}{l}\text { Tempo de } \\
\text { retenção } \\
\text { (min) }\end{array}$} & \multirow{2}{*}{$\begin{array}{c}\text { *Reta de calibração } \\
\qquad \mathbf{y}=\mathbf{A x}+\mathbf{B}\end{array}$} & \multirow{2}{*}{$\mathbf{R}^{2}$} & \multicolumn{2}{|c|}{$*^{*} \mathbf{x}=1 . \mathbf{A} \mathbf{y}^{-1}-\mathbf{B} \cdot \mathbf{A}^{-1}$} \\
\hline & & & & 1. $A^{-1}$ & 1. $A^{-1}$ \\
\hline Hidrogênio & 2.01 & $\begin{array}{c}y=341559,9085 x+ \\
500527,1375\end{array}$ & 0.9781 & 2.92774E-06 & 1.465415364 \\
\hline Nitrogênio & 2.32 & $\begin{aligned} y= & 33564,72579 x+ \\
& 40461,47846\end{aligned}$ & 0.9757 & 2.97932E-05 & 1.205476211 \\
\hline Metano & 3.22 & $\begin{aligned} & y= 118542,4492 x+ \\
& 143685,6491\end{aligned}$ & 0.9736 & $8.4358 \mathrm{E}-06$ & 1.212102922 \\
\hline $\begin{array}{l}\text { Gás } \\
\text { Carbônico }\end{array}$ & 4.61 & $\begin{aligned} \mathrm{y}= & 37537,02265 \mathrm{x}+ \\
& 47675,73719\end{aligned}$ & 0.9718 & $2.66404 \mathrm{E}-05$ & 1.27009906 \\
\hline
\end{tabular}

* Reta de calibração obtida pela análise das curvas para gases do cromatógrafo Shimadzu GC2010

** Expressão para cálculo dos gases, em que y é o valor obtido de área cromatográfica do gás correspondente. 
Produção de hidrogênio e metano a partir de subproduto da indústria sucroalcooleira, em reatores anaeróbios de fases separadas sob condição termofílica

162 


\section{APÊNDICE B}

\section{Interpretações das Expressões Estatísticas dos Dados Obtidos}

\section{Correlação ou Coeficiente de Correlação}

A Correlação (ou coeficiente de correlação) mede o grau pelo qual duas variáveis tendem a mudar juntas. O coeficiente descreve a força e a direção da relação. Quando $P=1$ significa uma correlação perfeita entre duas variáveis. Quando $P=-1$ significa uma correlação negativa perfeita entre duas variáveis, ou seja, inversamente proporcionais. Quando $P=0$ significa que as duas variáveis não dependem linearmente uma da outra.

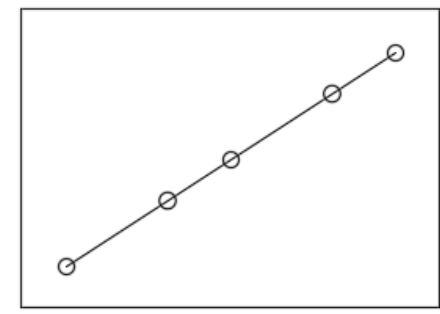

a)

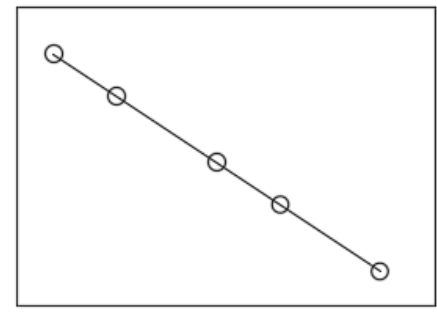

b)

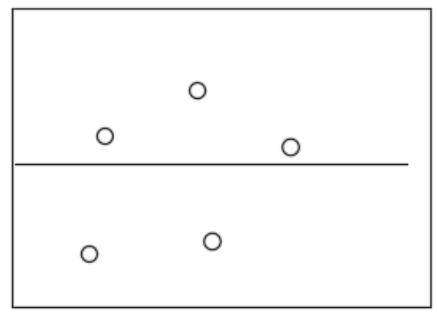

c)

Figura 54: Exemplo de interpretação de coeficiente de correlação. a) coeficiente de correlação positiva $P=1$, b) coeficiente de correlação negativa $P=-1$, c) coeficiente de correlação nula $P=0$.

\section{Covariância ou Variação Conjunta}

Covariância (ou variação conjunta) é uma medida do grau de interdependência (ou interrelação) numérica entre duas variáveis aleatórias. Assim, variáveis independentes têm covariância zero. A covariância é por vezes chamada de medida de dependência não linear entre as duas variáveis aleatórias. 
164

Boxplot

O boxplot, é um gráfico utilizado para avaliar a distribuição empírica dos dados. O gráfico é comumente usado para localizar e analisar a variação dentre diferentes grupos de dados. Assim é possível visualizar se em conjuntos de dados existe ou não equivalência.

O boxplot é formado pelo primeiro e terceiro quartil $(Q 1-Q 3)$ e pela mediana. As hastes inferiores e superiores se estendem, respectivamente, do quartil inferior até o menor valor não inferior ao limite inferior e do quartil superior até o maior valor não superior ao limite superior. Dados fora destes limites são considerados valores discrepantes (outliers).

O centro da distribuição é indicado pela linha da mediana. A dispersão é representada pela altura do retângulo (intervalo interquartil). O retângulo contém $50 \%$ dos valores do conjunto de dados. A posição da linha mediana no retângulo informa sobre a assimetria da distribuição. Uma distribuição simétrica teria a mediana no centro do retângulo. Se a mediana é próxima de $Q 1$, então, os dados são positivamente assimétricos. Se a mediana é próxima de Q3 os dados são negativamente assimétricos.

A Figura 55 apresenta o exemplo prático do formato e interpretação de um boxplot.

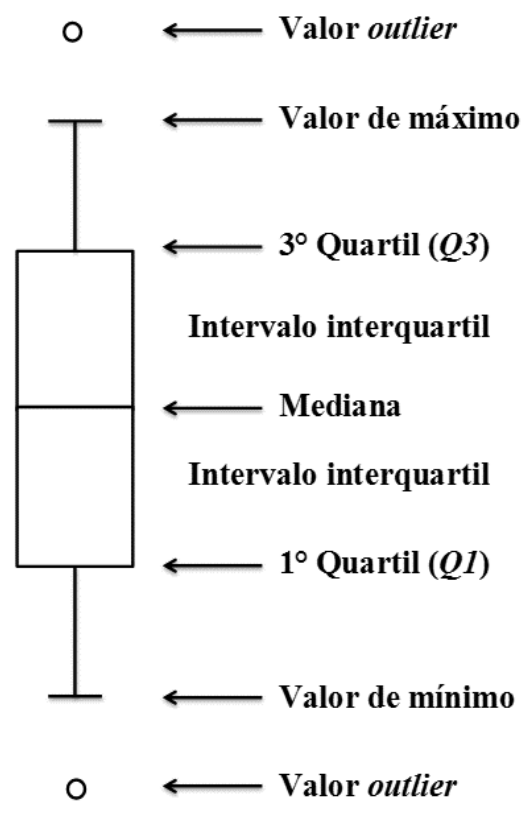

Figura 55: Exemplo do formato e interpretação do diagrama de boxplot. 